\title{
De euregionale arbeidsmarkt: van fictie naar werkelijkheid
}

Citation for published version (APA):

van Dam, J. W., \& de Grip, A. (1991). De euregionale arbeidsmarkt: van fictie naar werkelijkheid. Researchcentrum voor Onderwijs en Arbeidsmarkt, Faculteit der Economische Wetenschappen. ROA Reports No. 10 https://doi.org/10.26481/umarep.1991010

Document status and date:

Published: 01/01/1991

DOI:

10.26481/umarep.1991010

Document Version:

Publisher's PDF, also known as Version of record

\section{Please check the document version of this publication:}

- A submitted manuscript is the version of the article upon submission and before peer-review. There can be important differences between the submitted version and the official published version of record.

People interested in the research are advised to contact the author for the final version of the publication, or visit the DOI to the publisher's website.

- The final author version and the galley proof are versions of the publication after peer review.

- The final published version features the final layout of the paper including the volume, issue and page numbers.

Link to publication

\footnotetext{
General rights rights.

- You may freely distribute the URL identifying the publication in the public portal. please follow below link for the End User Agreement:

www.umlib.nl/taverne-license

Take down policy

If you believe that this document breaches copyright please contact us at:

repository@maastrichtuniversity.nl

providing details and we will investigate your claim.
}

Copyright and moral rights for the publications made accessible in the public portal are retained by the authors and/or other copyright owners and it is a condition of accessing publications that users recognise and abide by the legal requirements associated with these

- Users may download and print one copy of any publication from the public portal for the purpose of private study or research.

- You may not further distribute the material or use it for any profit-making activity or commercial gain

If the publication is distributed under the terms of Article $25 \mathrm{fa}$ of the Dutch Copyright Act, indicated by the "Taverne" license above, 
DE EUREGIONALE ARBEIDSMARKT: VAN FICTIE NAAR WERKELIJKHEID

- Knelpunten, initiatieven en beleidsmogelijkheden -

ROA-R-1991/10

J.W. van Dam

A. de Grip

\section{RESEARCHCENTRUM VOOR ONDERWIJS EN ARBEIDSMARKT}

Faculteit der Economische Wetenschappen

Rijksuniversiteit Limburg

Maastricht, november 1991 


\section{CIP-GEGEVENS KONIJKLIJKE BIBLIOTHEEK, DEN HAAG}

Dam, J.W. van

De Euregionale arbeidsmarkt: van fictie naar werkelijkheid: knelpunten, initiatieven en beleidsmogelijkheden / J.W. van Dam, A. de Grip. -Maastricht : Researchcentrum voor Onderwijs en Arbeidsmarkt. Faculteit der Economische Wetenschappen, Rijksuniversiteit Limburg. -(Rapport / Researchcentrum voor Onderwijs en Arbeidsmarkt, ISSN 0922-8098; 1991/10

Met lit. opg.

ISBN 90-5321-068-7

Trefw.: arbeidsmarkt; Euregio Maas-Rijn 


\section{INHOUDSOPGAVE}

VERANTWOORDING

SAMENVATTING

1. INLEIDING

2. DE ARBEIDSMARKT IN DE EUREGIO MAAS-RIJN

2.1. Ligging en bevolking

2.2. Economische structuur en werkgelegenheid 3

2.3. De pendelstromen in de Euregio Maas-Rijn 4

3. KNELPUNTEN RONDOM GRENSARBEID 7

3.1. Inleiding 7

3.2. Knelpunten in de dataverzameling en informatievoorziening 8

3.3. Knelpunten naar themagebied 10

3.3.1. Arbeidsmarkt 10

3.3.2. Onderwijs en scholing 12

3.3.3. Fiscus en financiën 13

3.3.4. Sociale zekerheid en pensioenen 16

Schema 1: Overzicht van de belangrijkste knelpunten per doelgroep en thema 22

4. HUIDIGE ACTIVITEITEN EN INITIATIEVEN 24

4.1. Inleiding 24

4.2. Overzicht van initiatieven per thema 24

4.2.1. Arbeidsmarkt 24

4.2.2. Onderwijs en scholing 25

4.2.3. Fiscus en financiën 26

4.2.4. Sociale zekerheid en pensioenen 28

4.3. Beschrijving van enkele initiatieven en samenwerkingsprojecten 29

4.3.1. Voorlichting met betrekking tot pendelproblematiek 29

4.3.2. Scholingsprojecten $\quad 30$

4.4. Overzicht van activiteiten 31

Schema 2: Overzicht van de belangrijkste activiteiten en initiatieven per thema 32 
5.1. Inleiding

5.2. Algemene aandachtspunten voor de beleidsontwikkeling 35

5.3. Beleidssuggesties 39

5.3.1. Algemene beleidssuggesties 39

5.3.2. Arbeidsmarkt 44

5.3.3. Onderwijs en scholing 45

5.3.4. Fiscus en financiën; sociale zekerheid en pensioenen 47

5.4. Naar een Euregionale arbeidsmarkt 50

LITERATUUR

BIJLAGE I: PERSONEN/INSTANTIES WAARMEE GESPREKKEN ZIJN GEVOERD 


\section{VERANTWOORDING}

Ter ondersteuning van het congres 'Euregio: Fictie of werkelijkheid?' over de arbeidsmobiliteit in de Euregio Maas-Rijn op 28 november 1991 in het MECC te Maastricht, is door het Provinciaal Bestuur van Nederlands Limburg, op instigatie van de Initiatiefgroep Euregionale Manifestatie, aan het Researchcentrum voor Onderwijs en Arbeidsmarkt (ROA) gevraagd een studie uit te voeren naar de knelpunten die zich voordoen bij de Euregionale arbeidsmobiliteit. Het onderzoek werd uitgevoerd door drs. J.W. van Dam, onder leiding van dr. A. de Grip. Dr. R.K.W. van der Velden heeft met name in de beginfase een ondersteunende rol vervuld in de begeleiding van het onderzoek.

Voor de inhoudelijke begeleiding van het onderzoek is op verzoek van de opdrachtgever een begeleidingscommissie samengesteld onder voorzitterschap van dr. L.L.M. Frederix, voorzitter van het Regionaal Bestuur voor de Arbeidsvoorziening Zuid-Limburg. De begeleidingscommissie bestond verder uit de volgende leden:

- drs. N.J.P.M. Bos: secretaris Initiatiefgroep Euregionale Manifestatie;

- drs. F.J.M. Boss, Provincie Nederlands Limburg;

- drs. H.J.M. Broekhuyse, lid Initiatiefgroep Euregionale Manifestatie;

- dhr. W. Friedrichs, Voorzitter F.N.V. Limburg, lid initiatiefgroep Euregionale Manifestatie;

- dhr. V. Konings, Directeur VDAB Tongeren;

- dhr. R. Loop, FOREM Brussel;

- dhr. R. Nouwen, Voorzitter Provinciaal Christelijk Vakverbond van Limburg, Hasselt;

dhr. F. Poelmann, Arbeitsamt Aachen;

mevr. M. Reggers, VDAB Tongeren;

drs. H.J.M. Rutten, lid Initiatiefgroep Euregionale Manifestatie;

dhr. M. Semer, FOREM Luik;

dhr. M.A.F. Soeren, Arbeidsbureau Sittard;

dr. J.J. Soeters, Provincie Nederlands Limburg, coördinator Euregionale Manifestatie;

mevr. Y. Sterkendries, VDAB Brussel.

Naast de leden van deze begeleidingscommissie is dank verschuldigd aan de heren $\mathrm{N}$. Bauer van de Vereniging van Europese Grenslandbewoners (VEG) en $M$. de Raeve, secretaris van de Dienst Grensarbeiders van de ACV te Hasselt, voor hun uitvoerige becommentariëring van concept-teksten van dit rapport.

In de eindfase van het onderzoek is, eveneens ter voorbereiding op het Euregionale Congres van 28 november 1991 in het MECC, onder leiding van dr. L.L.M. Frederix, een aantal groepsgesprekken gevoerd met deskundigen op de vier op het congres onderscheiden beleidsterreinen. Enkele belangrijkste uitkomsten van deze gesprekken zijn in dit rapport opgenomen. 
Samenvatting 
Het magische 'Europa zonder binnengrenzen' zal ongetwijfeld in eerste instantie vooral door de bewoners van de grensstreken aan den lijve ondervonden gaan worden of, zoals de Europese Commissie (1990) zelf aangeeft: 'het is duidelijk dat de grensarbeiders bijzonder getroffen worden door de vertraging die bij de verwezenlijking van de doelstellingen van de Europese Gemeenschap kan optreden'. De problemen die zich ondanks alle voornemens voor de Europese integratie, nog dagelijks in de praktijk voordoen, komen dan ook zeer sterk naar voren in één van de meest complexe Euregio's van Europa. In de Euregio Maas-Rijn komen niet alleen drie nationaliteiten bij elkaar, maar ook drie verschillende taal- en cultuurgebieden.

In de Euregio Maas-Rijn bewegen zich dagelijks naar schatting 20.000 personen over een landsgrens om hun werk te verrichten. Deze pendelbeweging is voornamelijk oostwaarts gericht: er werken relatief veel Belgen in Nederland of Duitsland en veel Nederlanders in de Duitse grensstreken.

Deze studie is verricht in het kader van het congres 'Euregio: Fictie of werkelijkheid' over de arbeidsmarktmobiliteit in de Euregio Maas-Rijn, op 28 november 1991 te Maastricht. In het voorliggende rapport wordt ingegaan op een aantal knelpunten die het functioneren van een Euregionale arbeidsmarkt zonder binnengrenzen nog in de weg staat. Tevens wordt een aanzet gegeven tot het formuleren van beleidsinitiatieven die de totstandkoming van een dergelijke Euregionale arbeidsmarkt dichterbij zouden kunnen brengen. In het rapport wordt aandacht geschonken aan de volgende vier thema's: Arbeidsmarkt; Onderwijs en scholing; Fiscus en financiën; en Sociale Zekerheid en pensioenen. Per thema wordt een aantal van de belangrijkste knelpunten en reeds ontwikkelde initiatieven kort weergegeven. Daarna komen enkele mogelijkheden voor nieuw beleid aan de orde. Voor een globaal overzicht van knelpunten en de reeds bestaande activiteiten en beleidsinitiatieven wordt ook verwezen naar respectievelijk de schema's 1 en 2 uit het onderzoekrapport.

\section{\%. AREEIDSMARKT}

Tot op heden komt het grootste aandeel van de internationale arbeidsmobiliteit tot stand door acties van individuele werkgevers of werknemers. De diverse overheidsdiensten en arbeidsvoorzieningsorganisaties spelen bij het bevorderen van een vrij verkeer van werknemers vooralsnog een bescheiden rol. De grensoverschrijdende bemiddeling door arbeidsvoorzieningsorganisaties vindt veelal plaats door persoonlijke contacten van bemiddelaars en door de uitwisseling van informatie over vacatures. Deze uitwisseling blijkt op enkele plaatsen redelijk succesvol te zijn. De geautomatiseerde vacature-uitwisseling tussen arbeidsbureaus verloopt daarentegen nog steeds stroef, onder meer vanwege de uiteenlopende nationale stelsels van vacature-registratie. Bovendien lijkt de 'trefkans' voor een geslaagde bemiddeling beperkt te zijn, indien er bij werkgevers en (potentiële) pendelaars onvoldoende inzicht is in de vraag-aanbod verhoudingen aan de andere zijde van de grens. Knelpunten doen zich hierbij zowel voor vanwege het ontbreken van datamateriaal als vanwege het ontbreken van een laag-drempelige geïntegreerde voorlichting. Met name het midden- en kleinbedrijf is vaak ook onbekend met de waarde van de diploma's in de buurlanden. Recentelijk zijn er op het terrein van de voorlichting belangrijke initiatieven genomen, zoals het geplande 'Euroloket' van de arbeidsvoorzieningsorganisaties.

Enkele beleidsaanbevelingen:

* Een inventariserend onderzoek naar de informatiebehoefte bij de verschillende doelgroepen in de Euregio en de mogelijkheden om in deze informatiebehoefte te kunnen voorzien is gewenst.

* De bij de Euregio betrokken overheden zouden zich moeten uitspreken voor een uniform, overkoepelend en geïntegreerd voorlichtingsbeleid, ten einde een verbrokkeling van initiatieven vanuit gescheiden circuits te voorkomen. 
* Het bureau van de Euregio Maas-Rijn zou een stimulerende en initiërende rol kunnen spelen bij het vergroten van de kennis (doelgroep, bereik, kosten) bij lokale media en bedrijven over de verschillende wervingsmogelijkheden, -kanalen en -procedures in de Euregio.

* In de informatievoorziening en beeldvorming naar personen en bedrijven toe, dienen niet alleen de momenteel bij grensarbeid ondervonden knelpunten benadrukt te worden, maar vooral ook de positieve aspecten van de schaalvergroting van de (Eu)regionale arbeidsmarkt.

* De diverse overheden of (semi-)overheidsinstellingen binnen de Euregio zouden een voortrekkersrol op de arbeidsmarkt kunnen vervullen, waarbij bovendien wederzijdse kennis en begrip van de 'beleidscultuur' in de buurlanden kan worden ingepast. Met name de uitwisseling van beleidsuitvoerend personeel, e.d., middels stages c.q. detacheringen zou daarbij een belangrijke plaats kunnen innemen.

\section{ONDERWISS EN SCHOLING}

$\mathrm{Er}$ is nog een groot aantal factoren waardoor het volgen van een opleiding over de grens wordt bemoeilijkt. Een tweetal knelpunten staat daarbij centraal:

- er is geen afstemming van de opleiding op de behoeften aan de andere kant van de grens;

- men heeft geen directe toegang tot de onderwijsstelsels in de buurlanden.

Bovendien ontbreekt het nog aan een toegankelijk overzicht van de vraag naar en het aanbod van opleidings- en scholingsmogelijkheden en de daarvoor geldende vooropleidingseisen. Ook doet zich een omvangrijk probleem voor op het gebied van de erkenning van diploma's, al bestaat er thans wel een algemene Richtlijn voor de erkenning van hogere onderwijsdiploma's en wordt er gewerkt aan een Richtlijn voor diploma's en certificaten op middelbaar niveau. Door de Europese Commissie zijn reeds tal van Europese actieprogramma's geïnitieerd op het terrein van onderwijs en scholing.

In de Euregio Maas-Rijn is momenteel sprake van een beperkt aantal grensoverschrijdende scholingsprojecten. Deze zijn voornamelijk op initiatief van opleidingsinstanties en brancheorganisaties tot stand gekomen. Opvallend is dat, ondanks mogelijke taalproblemen, verreweg de meeste projecten zich voordoen in de Nederlands-Duitse grensstreek. De projecten in het algemeen voortgezet onderwijs lijken zich vooralsnog met name te richten op kennismaking en uitwisseling. Bij het beroepsonderwijs lijkt er daarentegen vaker sprake te zijn van gezamenlijke scholingsprojecten, op het gebied van onder meer de gezondheidszorg, het economisch- en administratief onderwijs, de procestechnologie en computersimulatie, metaalbewerking en het internationale transport.

Enkele beleidsaanbevelingen:

* Initiatieven gericht op de integratie van onderwijsprogramma's zijn van groot belang.

* Er zou een inventarisatie gemaakt moeten worden van de formele-, organisatorische en financiële belemmeringen die een dergelijke integratie in de weg staan.

* De subsidieverstrekkers voor scholingsprojecten in de Euregio Maas-Rijn (overheden, scholingsfondsen), zouden een gezamenlijk opleidingsbeleidsplan kunnen initiëren, met gemeenschappelijke subsidievoorwaarden.

* Een 'Euregionaal actieplan regio-talen' lijkt gewenst.

* Nagegaan moet worden in hoeverre er in de Euregio Maas-Rijn behoefte is aan een instelling voor het initiëren of coördineren van grensoverschrijdende beroepsopleidingen en vakcursussen. Door samenwerking en afstemming op het gebied van opleidingen, scholing en examinering dient er langzamerhand een gelijkschakeling van opleidingskwalificaties van vaklieden te ontstaan waardoor de mobiliteit van werknemers kan toe nemen. 


\section{FISCUS EN FINANCIEN}

De problemen die zich voordoen op het gebied van belastingen en financiën als ook op het terrein van de sociale zekerheid zijn te onderscheiden in een viertal groepen van knelpunten:

1. Problemen als gevolg van conflicterende stelsels van wet- en regelgeving;

2. Problemen als gevolg van onjuiste of onvoldoende informatie bij pendelaars over de relevante wet- en regelgeving;

3. Problemen als gevolg van elkaar overlappende of herhalende uitvoeringsprocedures;

4. Problemen als gevolg van ondoorzichtige beroepsmogelijkheden of het ontbreken van adequate juridische bijstand;

Voor pendelaars tussen België en Nederland doen zich op het terrein van de persoonlijke inkomstenbelasting weinig problemen voor als gevolg van een adequaat bilateraal belastingverdrag. Veel meer problemen ondervinden de Belgische en Nederlandse pendelaars die werken in Duitsland. Deze problemen hebben betrekking op ongunstige tariefindelingen en het ontbreken van mogelijkheden voor de aftrekbaarheid van diverse kostenposten. Hierdoor worden vooral zelfstandigen, alleenstaande ouders en part-time pendelaars onevenredig zwaar belast. Er lijkt voorlopig geen zicht te zijn op een verbetering van deze situatie door bijvoorbeeld aanpassingen van de nationale wet- en regelgeving op basis van een Europese richtlijn of door bilaterale verdragen.

De informatievoorziening rondom de loonbelastingproblemen van pendelaars is nog steeds zeer ontoereikend. Enkele particuliere organisaties (Belgische vakbonden, een vereniging van grenslandbewoners) onderhouden een breed assortiment van voorlichtingsmiddelen die veelal alleen bestemd zijn voor leden/pendelaars. Met name de kleinere bedrijven en zelfstandigen worden hierdoor niet bereikt. De belastingdiensten zelf zijn op dit terrein nog nauwelijks actief. Bij de belasting-inning zijn naast de belastingdienst ook de werkgevers en/of uitkerende instanties als bedrijfsverenigingen of pensioenfondsen betrokken. Er blijkt in de uitvoeringpraktijk echter nauwelijks sprake te zijn van samenwerking of afstemming tussen de diverse betrokkenen. Ook lijken de mogelijkheden tot grensoverschrijdende beroepsprocedures en een eventuele rechtsgang voor individuele pendelaars in de praktijk nauwelijks haalbaar te zijn.

\section{Enkele beleidsaanbevelingen:}

* Met betrekking tot de uitvoering van de bilaterale belastingverdragen tussen Nederland, België en Duitsland zou voor de pendelaars een aanzienlijke verbetering bewerkstelligd kunnen worden, indien de werkgever en uitkerende instanties verantwoordelijk worden gesteld voor het aanvragen van ontheffing tot invordering van de directe inkomstenbelasting (de 'grensarbeidersverklaring').

* Teneinde de arbeidsmarktmobiliteit vanuit Duitsland naar Nederland en België en vanuit Nederland naar België te vergroten, dient ook informatie verzameld te worden over de knelpunten die bij deze (potentiële) pendelstromen kunnen optreden.

* Nagegaan moet worden of op het terrein van de grensoverschrijdende rechtsbijstand maatregelen ondernomen zouden kunnen worden. Gedacht kan worden aan het ondersteunen van individuele pendelaars bij de rechtsgang, het stimuleren van proefprocessen, het toegankelijk maken c.q. ontsluiten van regelgeving en jurisprudentie, etc.

* Wellicht dat er in België en de Bondsrepubliek Duitsland mogelijkheden zijn voor een overzichtelijker organisatie van de belastingdienst voor pendelaars.

* De grensoverschrijdende uitvoeringsprocedures zouden op 'pendel-vriendelijkheid' doorgelicht moeten worden door bilaterale projectteams. De Bureaus voor Belgische- en Duitse Zaken zouden daarvoor personele middelen toegewezen moeten krijgen. 


\section{SOCIALE ZEKERHEID EN -VOORZIENINGEN}

Hoewel er op basis van een Europese Richtlijn enige coördinatie tussen de nationale stelsels van sociale zekerheid tot stand is gebracht, blijken er in de dagelijkse praktijk voor individuele pendelaars nog vooral problemen op te treden op het gebied van de ziektekosten, de arbeidsongeschiktheid, en de ouderdomsvoorzieningen en pensioenen. Deze problemen worden deels veroorzaakt door de principeel verschillende uitgangspunten die aan de nationale zekerheidsstelsels ten grondslag liggen en zijn voor een ander deel ook het gevolg van aanzienlijke verschillen tussen de geldende criteria voor toe- en uittreding, premie- en uitkeringshoogten e.d..

Evenals bij de fiscaliteit worden veel problemen veroorzaakt door een zeer gebrekkig informatieniveau bij de pendelaars. Daarbij speelt niet alleen de complexiteit van de betreffende regelingen een rol maar ook het feit dat begrijpelijke, op de persoonlijke situatie toegesneden informatie en advies, op slechts enkele plaatsen voorhanden is. Naast de grote informatiebehoefte doet zich het probleem voor dat de bij het uitvoeringsproces betrokken instanties in geringe mate met elkaar samenwerken en vaak nogal 'landinwaarts' zijn gericht. Onnodig lange, omslachtige en voor de burger frustrerende procedures zijn daarvan het gevolg.

Enkele beleidsaanbevelingen:

* Bij het ontwikkelen en vaststellen van nieuwe wet- en regelgeving op met name het gebied van de sociale zekerheid, wordt nog steeds in onvoldoende mate rekening gehouden met de gevolgen daarvan voor grensoverschrijdende werknemers. Euregionale politici en belangenorganisaties zullen daarop alert moeten zijn.

* Er zal op grotere schaal en op een meer cliëntgerichte wijze informatie en advies beschikbaar moeten komen over de gevolgen voor de sociale zekerheid, van het werken in het buitenland.

* De bij de beleidsaanbevelingen op fiscaal terrein reeds genoemde beleidsaanbevelingen op het terrein van grensoverschrijdende rechtsbijstand, informatielacunes en uitvoeringsprocedures zijn onverkort van toepassing op het gebied van de sociale zekerheid.

\section{ALGEMENE AANDACHTSPUNTEN VOOR OE BELEIDSONTMIKKELING}

In het rapport wordt naast de diverse beleidsaanbevelingen op het terrein van de genoemde vier themagebieden ook een negental uitgangspunten geformuleerd waarmee bij de ontwikkeling van grensoverschrijdend beleid rekening zou moeten worden gehouden. Het gaat daarbij om de volgende aandachtspunten:

- ontwikkelen van een visie op de Euregio Maas-Rijn als bestuurlijke entiteit;

- het formuleren van een motiverend en inspirerend beleidskader voor Euregionale samenwerking;

- bezinning op succes- en faalfactoren van grensoverschrijdende samenwerking;

- meer aandacht voor potentiële pendelaars;

- meer aandacht voor de informatieverstrekking aan het midden- en kleinbedrijf en zelfstandige beroepsbeoefenaren;

- netwerkvorming in de Euregio en tussen Euregio's;

- uitwerken van de mogelijkheden voor incentive-sturing;

- uitwerken van een juridisch (bestuursrechtelijk) kader voor samenwerkingsprojecten;

- meer aandacht voor pendelaspecten bij het totstandkomen van nieuwe wet- en regelgeving, met name op het terrein van de sociale voorzieningen 


\section{NAAR EEN EUREGIONALE ARBEIDSMARKT}

Hoewel het aan de ene kant aantrekkelijk is dat een grote verscheidenheid aan organisaties een bijdrage levert aan de totstandkoming van een Euregionale arbeidsmarkt, kan dit tegelijkertijd ook nadelig zijn indien allerlei initiatieven elkaar overlappen of zonder enige coördinatie worden ontwikkeld.

Voor een meer gecoördineerde aanpak waarvan het geheel meer is dan de som der delen, zal in eerste instantie binnen de Euregio Maas-Rijn een vijftal beleidsinitiatieven nuttig kunnen zijn:

- het formuleren van een politieke visie op de mogelijkheden en wenselijkheden ten aanzien van de bestuurlijke samenwerking in de Euregio Maas-Rijn;

- het formuleren van een motiverend en inspirerend beleidskader, waarbinnen de verschillende meer concrete beleidsinitiatieven kunnen worden gepositioneerd;

- een aanzet geven tot de netwerkvorming binnen de Euregio, door het instellen van een 'Euregio Adviesraad' en thematische werkgroepen bestaande uit overheidsvertegenwoordigers, sociale partners en andere belanghebbenden (zie ook Buck, 1990);

- het voteren van regionale gelden ten behoeve van de beleidsterreinen die prioriteit hebben in het kader van de Euregionale samenwerking, in centrale Euregionale fondsen;

- het ontwikkelen van een actief informatiebeleid, waarmee de Euregio Maas-Rijn zich zowel binnen als buiten de Euregio kan profileren.

Vanuit de Initiatiefgroep Euregiocongres zou een appèl gedaan kunnen worden in de richting van het Gouverneursoverleg om op bovengenoemde punten beleidsinitiatieven te ontplooien.

Hoewel de ontwikkelingen op communautair en nationaal niveau vanzelfsprekend van groot belang kunnen zijn voor de totstandkoming van een gemeenschappelijke arbeidsmarkt in de Euregio Maas-Rijn, moet ook worden beseft dat juist de samenwerking in de grensregio's een belangrijke stimulans kan geven aan de Europese samenwerking in het algemeen. De Euregio's vervullen daarmee een belangrijke katalysatorfunctie voor het Europese integratieproces. 


\section{Zusammenfassung}


Das magische 'Europa ohne Binnengrenzen' werden zweifellos in erster Linie vor allem die Bewohner der Grenzgebiete erleben oder, wie die Europäische Kommission (1990) selbst sagt: 'Es ist deutlich, daß die Grenzarbeiter durch die Verzögerung, die bei der Realisierung der Zielsetzungen der Europäischen Gemeinschaft auftreten kann, besonders betroffen sind.' Die Probleme, die sich trotz aller guten Absichten für die europäische Integration noch täglich in der Praxis zeigen, kommen daher sehr stark in einer der komplexesten Euregionen Europas zum Ausdruck. In der Euregion Maas-Rhein treffen sich nicht drei Nationalitäten, sondern auch drei unterschiedliche Sprach- und Kulturgebiete.

In der Euregion Maas-Rhein überschreiten täglich schätzungsweise 20.000 Personen die Landesgrenze, um zu ihrer Arbeitsstelle zu gelangen. Diese Pendelbewegung richtet sich hauptsächlich ostwärts. Es arbeiten relativ viele Belgier in den Niederlanden oder Deutschland und viele Niederländer in den deutschen Grenzgebieten.

Diese Studie wurde im Rahmen des euregionalen Kongresses 'Fiktion oder Wirklichkeit' über die Arbeitsmobilität in der Euregion Maas-Rhein, der am 28. November 1991 in Maastricht stattfinden wird, durchgeführt. Dabei wurden einige Engpässe betrachtet, die dem Funktionieren eines euregionalen Arbeitsmarktes ohne Binnengrenzen noch im Wege stehen. Gleichzeitig wird ein Anstoß zur Formulierung der arbeitspolitischen Initiativen, die das Zustandekommen eines solchen euregionalen Arbeitsmarktes schneller herbeiführen könnten, gegeben. In dem Bericht wird folgenden vier Themen Aufmerksamkeit gewidmet: Arbeitsmarkt; Bildung und Ausbildung; Fiskus und Finanzen; Soziale Sicherheit und Pensionen. Je Thema werden einige der wichtigsten Engpässe und bereits entfaltete Initiativen kurz dargelegt. Danach werden einige Möglichkeiten für eine neue Politik besprochen. Für eine globale Übersicht über die Engpässe und die bereits ausgeführten Aktivitäten und arbeitspolitischen Initiativen wird auch auf die Schemas 1 bzw. 2 des Untersuchungsberichtes hingewiesen.

\section{AREEITSMARKT}

Bis heute kommt der größte Teil der internationalen Arbeitsmobilität durch Aktionen einzelner Arbeitgeber oder Arbeitnehmer zustande. Die einzelnen Behörden und Arbeitsverwaltungen spielen bei der Förderung eines freien Verkehrs von Arbeitnehmern fürs erste nur eine bescheidene Rolle. Die grenzüberschreitende Vermittlung der Arbeitsverwaltungen findet oft über persönliche Kontakte der Vermittler und den Austausch von Informationen über offene Stellen statt. Dieser Austausch hat sich an einigen Orten als relativ erfolgreich erwiesen. Der automatisierte Austausch über Stellenangebote zwischen den Arbeitsämtern verläuft dagegen noch etwas träge, u.a. infolge der unterschiedlichen Systeme für die Anmeldung offener Stellen in den einzelnen Ländern. Außerdem scheint die Erfolgsquote einer Vermittlung begrenzt zu sein, wenn bei Arbeitgebern und (potentiellen) Pendlern nicht genug Einsicht in das Verhältnis von Angebot und Nachfrage auf der anderen Seite der Grenze besteht. Engpässe treten dabei sowohl wegen fehlenden Datenmaterials als auch wegen des Fehlens einer integrierten Aufklärung mit niedriger Schwelle auf. Vor allem die kleinen und mittleren Unternehmen kennen oft den Wert der Diplome aus den Nachbarländern nicht. Vor kurzem wurden auf dem Gebiet der Aufklärung wichtige Initiativen ergriffen, wie der geplante 'Euroschalter' der Arbeitsverwaltung.

Einige arbeitspolitische Empfehlungen:

* Eine inventarisierende Untersuchung nach dem Informationsbedarf der einzelnen Zielgruppen in der Euregion und die Möglichkeiten, diesen Informationsbedarf zu befriedigen, sind erwünscht.

* Die zur Euregion gehörenden Behörden müßten sich für eine einheitliche übergreifende und integrierende Aufklärungspolitik entscheiden, um eine Zersplitterung der Initiativen von getrennten Kreisen aus zu verhindern. 
* Das Büro der Euregion Maas-Rhein könnte bei der Erweiterung der Kenntnisse (Zielgruppe, Bereich, Kosten) bei lokalen Medien und Betrieben über die unterschiedlichen Werbemöglichkeiten, -kanäle und -verfahren in der Euregion eine fördernde und initiierende Rolle spielen.

* Bei der Informationsverschaffung und dem Image in bezug auf Personen und Betriebe müssen nicht nur die augenblicklich bei der Grenzarbeit auftretenden Engpässe hervorgehoben werden, sondern vor allem auch die positiven Aspekte der Ausweitung des (eu)regionalen Arbeitsmarktes.

* Die einzelnen Behörden und (halb-)behördlichen Einrichtungen innerhalb der Euregion müßten auf dem Arbeitsmarkt eine Vorreiterrolle spielen können, wobei außerdem Kenntnis und Verständnis für die 'politische Kultur' der anderen in den Nachbarländern gefördert werden können. Vor allem der Austausch des ausführenden Personals u.dgl. in Form eines Praktikums bzw. einer zeitweiligen Entsendung könnte dabei eine wichtige Rolle spielen.

\section{BLLUNG UND AUSBLDUNG}

Verschiedene Faktoren erschweren die Möglichkeit, eine Ausbildung jenseits der Grenze zu absolvieren. Zwei Engpässe stehen dabei im Mittelpunkt:

- die Ausbildung ist nicht auf die Bedürfnisse auf der anderen Seite der Grenze abgestimmt;

- man hat keinen direkten Zugang zu dem Ausbildungssystem in den Nachbarländern.

Außerdem fehlt es auch an einer Übersicht über Angebot und Nachfrage im Rahmen der Bildungs- und Ausbildungsmöglichkeiten und über die diesbezüglich geltenden Anforderungen an die Vorbildung. großes Problem ist auch die Anerkennung von Diplomen, auch wenn es inzwischen eine allgemeine Richtlinie für die Anerkennung von Hochschuldiplomen gibt und eine Richtlinie für Diplome und Zertifikate anderer Ausbildungen ausgearbeitet wird. Die Europäische Kommission hat bereits zahlreiche europäische Programme auf dem Gebiet von Bildung und Ausbildung initiiert.

In der Euregion Maas-Rhein gibt es im Augenblick einige grenzüberschreitende Ausbildungsprojekte. Diese Projekte sind hauptsächlich auf Initiative von Ausbildungsinstituten und Branchenorganisationen zustande gekommen. Auffallend ist, daß trotz möglicher Sprachprobleme bei weitem die meisten Projekte im niederländisch-deutschen Grenzbereich durchgeführt werden. Die Projekte im allgemeinen weiterführenden Unterricht scheinen sich fürs erste vor allem auf Kennenlernen und Austausch zu richten. Im berufsbildenden Unterricht ist dagegen des öfteren die Rede von gemeinsamen Ausbildungsprojekten, die sich u.a. auf Gesundheitswesen, Wirtschafts- und Verwaltungsunterricht, Prozeßtechnologie und Computersimulation, Metallbearbeitung und internationalen Transport beziehen.

Einige arbeitspolitische Empfehlungen:

* Initiativen, die sich auf die Integration von Ausbildungsprogrammen richten, sind von großer Bedeutung.

* Es müßte eine Bestandsaufnahme von den formellen, organisatorischen und finanziellen Hindernissen, die einer solchen Integration im Wege stehen, gemacht werden.

* Die Zuschußgeber für Ausbildungsprojekte in der Euregion Maas-Rhein (Behörden, Ausbildungsfonds) müßten ein gemeinsames Ausbildungsprogramm mit gemeinsamen Zuschußbedingungen initiieren können.

* Ein 'euregionaler Aktionsplan Sprachen in der Region' erscheint wünschenswert.

* Es muß geprüft werden, inwieweit in der Euregion Maas-Rhein Bedarf an einer Institution für das Initiieren und Koordinieren von grenzüberschreitenden Berufsausbildungen und Fachkursen besteht. Durch die Zusammenarbeit und Abstimmung im Bereich der Ausbildungen, Weiterbildung und Prüfungen müssen allmählich die Ausbildungsqualifikationen von Fachkräften gleichgeschaltet werden, wodurch die Mobilität der Arbeitnehmer zunehmen kann. 
Die Probleme, die im Steuer- und Finanzbereich sowie auf dem Gebiet der sozialen Sicherheit auftreten, lassen sich in vier Gruppen von Engpässen unterscheiden:

1. Probleme infolge zueinander im Widerspruch stehender Gesetze und Vorschriften;

2. Probleme infolge unrichtiger oder unzureichender Informationen für Pendler über die relevanten Gesetze und Vorschriften;

3. Probleme infolge von einander überlappender oder sich wiederholender Ausführungsverfahren;

4. Probleme infolge undurchsichtiger Berufungsmöglichkeiten oder das Fehlen eines adäquaten Rechtsbeistandes.

Für Pendler zwischen Belgien und den Niederlanden treten infolge eines adäquaten bilateralen Steuervertrages im Bereich der persönlichen Einkommensteuer wenig Probleme auf. Auf viele Schwierigkeiten stoßen belgische und niederländische Pendler, die in Deutschland arbeiten. Diese Schwierigkeiten beziehen sich auf ungünstige Einteilungen in Tarifgruppen und fehlende Möglichkeiten, verschiedene Unkosten in Abzug zu bringen. Dadurch werden vor allem Selbständige, allein- erziehende Elternteile und Zeitkräfte unverhältnismäßig schwer belastet. Vorläufig scheint sich die Situation nicht zu bessern, z.B. durch Anpassungen der Landesgesetze und -vorschriften aufgrund einer europäischen Richtlinie oder durch bilaterale Verträge.

Die Informationsverschaffung in bezug auf die Lohnsteuerprobleme von Pendlern ist noch immer sehr unzureichend. Einige private Organisationen (belgische Gewerkschaften, ein Verband der Grenzlandbewohner) verfügen über ein breites Sortiment von Aufklärungsmaterial, das meistens nur für Mitglieder/Pendler bestimmt ist. Diese Informationen erreichen leider die kleineren Betriebe und Selbständigen nicht. Die Steuerbehörden selbst sind auf diesem Gebiet noch kaum aktiv. Bei der Steuereinziehung sind neben dem Finanzamt auch die Arbeitgeber und/oder leistungzahlenden Instanzen wie Bedrijfsverenigingen (niederländische Sozialversicherungsträger) oder Pensionskassen beteiligt. Bei der praktischen Ausführung gibt es kaum eine Zusammenarbeit oder Abstimmungen zwischen den Interessenten. Auch die Möglichkeiten zu grenzüberschreitenden Berufungsverfahren und mögliche Rechtsverfahren für individuelle Pendler scheinen in der Praxis kaum realisierbar zu sein.

Einige arbeitspolitische Empfehlungen:

* In bezug auf die Ausführung der bilateralen Steuerverträge zwischen den Niederlanden, Belgien und Deutschland könnte für die Pendler eine beträchtliche Verbesserung bewerkstelligt werden, wenn der Arbeitgeber und die zahlenden Instanzen für das Beantragen einer Befreiung zur Einziehung der direkten Einkommensteuer (die Grenzarbeitererklärung) verantwortlich wären.

* Um die Arbeitsmarktmobilität von Deutschland aus in die Niederlande und nach Belgien und von den Niederlanden aus nach Belgien zu vergrößern, müssen auch Informationen über Engpässe, die bei diesen (potentiellen) Pendelströmen auftreten können, gesammelt werden.

* Es muß geprüft werden, ob auf dem Gebiet des grenzüberschreitenden Rechtsbeistandes Maßnahmen getroffen werden können. Es handelt sich dabei um die Unterstützung einzelner Pendler bei Rechtsverfahren, die Stimulierung von Versuchsprozessen, das Zugänglichmachen bzw. Erschließen von Vorschriften, Rechtsprechung usw.

* Möglicherweise gibt es in Belgien und der Bundesrepublik Deutschland Möglichkeiten, die Steuerinformationen für Pendler übersichtlicher zu gestalten.

* Die grenzüberschreitenden Ausführungsverfahren müßten von bilateralen Projektteams auf 'Pendler-Freundlichkeit' untersucht werden. Die Büros für belgische und deutsche Angelegenheiten müßten dafür Zuschüsse für den Personalbestand erhalten. 


\section{SOZIALE SICHERHEIT UND SOZIALE EINRICHTUNGEN}

Obwohl aufgrund einer europäischen Richtlinie eine gewisse Koordinierung zwischen den Landessystemen der sozialen Sicherheit zustande gekommen ist, haben einzelne Pendler in der täglichen Praxis noch immer Probleme vor allem bei der Krankenversicherung, der Arbeitsunfähigkeit und den Altersrenten und Pensionen. Diese Probleme werden zum Teil durch die prinzipiell unterschiedlichen Ausgangspunkte, die den nationalen Sicherheitssystemen zugrunde liegen, verursacht. Sie sind

auch zum Teil die Folge der beträchtlichen Unterschiede zwischen den geltenden Kriterien für Zugang und Abgang, Höhe der Beiträge und Leistungen und dergleichen.

Ebenso wie bei der Steuergesetzgebung sind viele Probleme die Folge eines sehr lückenhaften Informationsniveaus bei den Pendlern. Dabei spielt nicht nur die Komplexität der entsprechenden Regelungen eine Rolle, sondern auch die Tatsache, daß es verständliche, auf die persönliche Situation zugeschnittene Informationen und Ratschläge nur an wenigen Stellen gibt. Neben dem großen Informationsbedarf tritt auch das Problem auf, daß die beim Ausführungsprozeß beteiligten Instanzen kaum zusammenarbeiten und oft mehr auf das 'eigene Land' gerichtet sind. Unnötig lange, umständliche und für den Bürger frustrierende Verfahren sind die Folge.

Einige arbeitspolitische Empfehlungen:

* Beim Entwickeln und Erlassen neuer Gesetze und Vorschriften vor allem im Bereich der sozialen Sicherheit werden die Folgen für den grenzüberschreitenden Arbeitnehmer noch immer unzureichend berücksichtigt. Euregionale Politiker und Interessenorganisationen werden darauf achten müssen.

* Es müssen in größerem Umfang und in einer mehr kundenorientierten Weise Informationen und Ratschläge über die Folgen der sozialen Sicherheit des Arbeitens im Ausland zur Verfügung gestellt werden.

* Die bei den politischen Empfehlungen im Steuerbereich bereits genannten Aspekte wie grenzüberschreitender Rechtsbeistand, Informationslücken und Ausführungsverfahren sind selbstverständlich auch für die soziale Sicherheit wichtig.

\section{ALLGEMEINE SCHWERPUNKTE BEI DER ENTWICKLUNG DER POLITK}

In dem Bericht werden außer den verschiedenen politischen Empfehlungen im Bereich der genannten vier Themen auch neun Ausgangspunkte formuliert, die bei der Entwicklung der grenzüberschreitenden Politik berücksichtigt werden müssen. Es handelt sich dabei um folgende Schwerpunkte:

- Entwicklung einer Vision auf die Euregion als Verwaltungseinheit;

- das Formulieren einer motivierenden und inspirierenden Politik;

- Besinnung auf Erfolgs- und Scheiterungsfaktoren der grenzüberschreitenden Zusammenarbeit;

- mehr Aufmerksamkeit für potentielle Pendler;

- mehr Aufmerksamkeit für die Informationsverschaffung für die kleinen und mittleren Unternehmen und selbständige Berufe;

- Netzwerkbildung in der Euregion und zwischen den Euregionen;

- Ausarbeitung der Möglichkeiten für Anreize;

- Ausarbeitung eines juristischen (verwaltungsrechtlichen) Rahmens für Kooperationsprojekte;

- mehr Aufmerksamkeit für Aspekte des Pendelns beim Zustandekommen neuer Gesetze und Vorschriften, vor allem im Bereich der sozialen Einrichtungen. 


\section{AUF DEM WEG ZU EINEM EUREGIONALEN ARBEITSMARKT}

Obwohl es einerseits reizvoll ist, daß eine große Verschiedenheit an Organisationen einen Beitrag zum Zustandekommen eines euregionalen Arbeitsmarktes leistet, kann das gleichzeitig auch Nachteile haben, und zwar dann, wenn verschiedene Initiativen einander überlappen oder ohne irgendeine Koordination entwickelt werden.

Für eine gut koordinierte Inangriffnahme, deren Ganzes mehr ist als nur die Summe der Teile, werden in erster Linie innerhalb der Euregion Maas-Rhein fünf politische Initiativen nützlich sein können:

- die Formulierung einer politischen Vision auf die Möglichkeiten und Wünsche in bezug auf die verwaltungstechnische Zusammenarbeit in der Euregion Maas-Rhein;

- die Formulierung eines motivierenden und inspirierenden politischen Konzeptes, in das die einzelnen konkreten Initiativen eingefügt werden können;

- einen Anstoß zu der Netzwerkbildung innerhalb der Euregion geben, indem ein 'Euregion Beratungsgremium' und thematische Arbeitsgruppen, zu denen Vertreter der Regierung, der Sozialpartner und anderer Interessenten gehören (siehe auch Buck, 1990), gebildet werden.

- die Bewilligung regionaler Gelder für die Politikbereiche, die im Rahmen der euregionalen Zusammenarbeit Priorität haben. Die Gelder werden in zentrale euregionale Fonds eingezahlt.

- die Entwicklung einer aktiven Informationspolitik, mit der sich die Euregion Maas-Rhein sowohl innerhalb als außerhalb der Euregion profilieren kann.

Die Initiativgruppe des Euregionkongresses könnte den Verhandlungsausschuß der Gourverneure auffordern, in bezug auf die obigen Aspekte politische Initiativen zu entfalten.

Obwohl die Entwicklungen auf Landes- und EG-Ebene für das Zustandekommen eines gemeinsamen Arbeitsmarktes in der Euregion Maas-Rhein selbstverständlich von großer Bedeutung sein können, sollte man nicht übersehen, daß gerade die Zusammenarbeit in den Grenzgebieten ein wichtiger Anreiz für die europäische Zusammenarbeit im allgemeinen sein kann. Die Euregionen erfüllen damit eine wesentliche Katalysatorfunktion für den europäischen Integrationsprozeß. 
Synthese 
Le monde idéal de l'Europe sans frontières" sera sans aucun doute vécue comme une réalité, en tout premier lieu, par les habitants des régions frontalières. Comme le dit la Commission européenne (1990), "il est clair que le retard susceptible d'affecter la réalisation des objectifs de la Communauté européenne a un impact tout particulier sur les travailleurs frontaliers.

On comprendra donc que les problèmes concrets qui se posent encore quotidiennement, en dépit de tous les projets d'intégration européenne, pèsent spécifiquement sur l'une des "Eurégions" les plus complexes d'Europe, à savoir l'Eurégion Meuse-Rhin. Celle-ci, en effet, ne réunit pas seulement trois nationalités, mais également trois territoires linguistiques et culturels.

Dans cette région, on estime à quelque $\mathbf{2 0 . 0 0 0 ~ l e ~ n o m b r e ~ d e ~ p e r s o n n e s ~ q u i ~ f r a n c h i s s e n t ~ c h a q u e ~}$ jour la frontière de leur pays pour se rendre à leur travail. La direction principale de ce mouvement pendulaire est l'est: les Belges travaillant aux Pays-Bas et en Allemagne sont relativement nombreux, de même que les Néerlandais dans les régions frontalières allemandes.

La présente étude s'insère dans le cadre du Congrès eurégional "Fiction ou réalité", sur la mobilité de la main-d'oeuvre dans l'Eurégion Meuse-Rhin, qui se déroulera à Maastricht le 28 novembre 1991. Elle se penche sur un certain nombre d'obstacles au bon fonctionnement d'un marché du travail eurégional sans frontières qui continuent de subsister. Au-delà de la simple identification des problèmes, elle suggère un certain nombre d'initiatives politiques susceptibles de nous rapprocher d'un véritable marché eurégional du travail.

Le rapport aborde successivement les quatre thèmes suivants: marché du travail, enseignement et formation, fiscalité et financement, sécurité sociale et régimes de pensions. II rappelle brièvement, pour chacun de ces thèmes, les obstacles majeurs et les initiatives déjà prises. II propose ensuite une série de nouvelles voies d'action. Les schémas 1 et 2 du rapport de recherche présentent une vue d'ensemble des freins subsistants, ainsi que des activités déjà en cours et des initiatives politiques déjà prises.

\section{LE MARCHÉ DU TRAVAIL}

Jusqu'ici, la majeure partie de la mobilité internationale de la main-d'oeuvre est le fait d'employeurs ou de travailleurs individuels. Les diverses administrations compétentes et les Services pour l'Emploi ne jouent encore qu'un rôle modeste en matière de promotion de la libre circulation des travailleurs. L'essentiel des activités transfrontalières de placement assurées par les Services pour l'Emploi trouvent leur source dans les contacts personnels et les échanges d'information sur les offres d'emploi entre agents de placement. Une telle collaboration semble produire déjà de bons résultats en un certain nombre d'endroits. Par contre, l'échange informatisé d'information sur les offres d'emploi entre Services pour l'Emploi reste hésitant, en raison notamment des différences entre systèmes nationaux d'enregistrement des offres d'emploi. S'y ajoute le fait que les chances de succès d'un placement transfrontalier restent limitées en l'absence d'une bonne connaissance, par les employeurs et par les travailleurs frontaliers potentiels, des relations entre l'offre et la demande de travail de l'autre côté de la frontière. Les problèmes résultent ici, soit de l'indisponibilité de l'information de base, soit de la difficulté d'accès à celle-ci, par manque d'intégration. En particulier, les petites et moyenne entreprises connaissent mal la valeur des diplômes délivrés dans les pays voisins. Des initiatives ont récemment été prises en vue d'améliorer cet accès à l'information, notamment sous la forme du projet d"Euroguichet" des Services pour l'Emploi. 
Quelques recommandations d'action:

* Identification des besoins d'information des divers groupes-cibles de l'Eurégion et des possibilités de les rencontrer.

* Adoption, par les administrations concernées de l'Eurégion, d'une structure fédérative d'information harmonisée et intégrée, en vue d'éviter la dispersion des initiatives émanant des différents circuits.

* Rôle de pionnier et de promoteur du Bureau de l'Eurégion Meuse-Rhin en matière d'amélioration de l'information (groupes-cibles, portée, coûts) des médias et des employeurs locaux sur les possibilités, canaux et procédures de recrutement dans l'ensemble de l'Eurégion.

* Accent mis, dans l'effort d'information auprès des individus et des entreprises, non seulement sur les obstacles actuels, mais aussi et surtout sur les aspects positifs de l'élargissement du marché du travail (Euro)régional.

* Possibilité d'initiative des divers pouvoirs publics et organismes (para)publics de l'Eurégion, en matière de gestion du marché du travail et de promotion de la connaissance et de la compréhension réciproques des "cultures administratives" des pays voisins. Les échanges de collaborateurs, dans le cadre de stages ou de procédures de détachement, pourraient s'avérer particulièrement fructueux à cet égard.

\section{ENSEIGNEMENT ET FORMATION}

Parmi le grand nombre de facteurs qui continuent à faire obstacle à la poursuite de formations audelà des frontières, nous en retiendrons deux, en raison de leur importance spécifique:

- absence d'alignement des formations sur les besoins de l'autre côté de la frontière;

- absence d'accès direct aux systèmes éducatifs des pays voisins.

S'y ajoute l'absence d'une vue d'ensemble aisément accessible de l'offre et de la demande de filières d'enseignement et de formation et de leurs prérequis. II demeure, en outre, un problème majeur de reconnaissance mutuelle des diplômes, en dépit de la Directive générale sur la reconnaissance des diplômes de l'enseignement supérieur et de la préparation d'une Directive sur les diplômes et certificats de l'enseignement secondaire. On rappellera, à cet égard, les très nombreuses initiatives prises par la Commission européenne en matière d'enseignement et de formation.

Un certain nombre de projets de formation transfrontaliers sont actuellement envisagés dans l'Eurégion Meuse-Rhin. L'initiative en est essentiellement due à des institutions éducatives et organismes professionnels. On remarquera que la possibilité de problèmes d'ordre linguistique n'empêche pas que la plupart de ces projets se situent dans la région frontalière Pays-BasAllemagne. Les projets concernant l'enseignement général du second degré semblent toutefois se limiter encore à des prises de contact et à l'initiation d'échanges. Dans l'enseignement professionnel, au contraire, il s'agit plus souvent de projets communs de formation portant, notamment, sur les soins de santé, l'économie et l'administration, la technologie des processus, la simulation informatisée, la transformation des métaux et le transport international.

Quelques recommandations d'action:

* Importance des initiatives visant l'intégration des programmes d'enseignement.

* Identification des obstacles institutionnels, organisationnels et financiers à une telle intégration.

* Possibilité pour les pouvoirs subsidiants de projets de formation en Eurégion (pouvoirs publics, fonds scolaires), de lancer un programme-cadre de formations régi par des conditions de financement communes. 
* Plan d'action Eurégional en faveur des langues de la région.

* Étude de l'intérêt, en Eurégion, d'un organisme chargé de mettre sur pied ou de coordonner des formations professionnelles transfrontalières ou des cours spécialisés. La collaboration et la concertation en matière de formation, d'apprentissage et de procédures d'examen sont, en effet, génératrices d'harmonisation progressive des qualifications professionnelles et donc de mobilité accrue des travailleurs.

\section{FISCALITÉ ET FINANCEMENT}

En matière de fiscalité, de financement et de sécurité sociale, les problèmes peuvent être classés en quatre groupes:

1. Problèmes résultant de différences d'ordre législatif et réglementaire;

2. Problèmes suscités par l'information incorrecte ou insuffisante des travailleurs transfrontaliers sur les législations et réglementations pertinentes;

3. Problèmes liés au dédoublement ou aux interférences des procédures administratives;

4. Problèmes dus au manque de transparence du marché du travail ou à l'absence d'une assistance juridique appropriée.

Entre la Belgique et les Pays-bas, peu de problèmes se posent en ce qui concerne l'impôt sur les personnes physiques, grâce à l'existence d'un accord fiscal bilatéral adéquat. La situation est nettement moins aisée pour les Belges et les Néerlandais qui travaillent en Allemagne, où ils se heurtent à un traitement fiscal défavorable et à l'impossibilité de déduire un certain nombre de frais professionnels. II en résulte une charge fiscale particulièrement lourde pour les indépendants, les parents isolés et les travailleurs à temps partiel. II n'y a, à l'heure actuelle, que de faibles perspectives d'amélioration de cette situation, notamment par adaptation des législations et réglementations nationales sur la base d'une directive européenne ou de traités bilatéraux.

L'information des travailleurs frontaliers sur la fiscalité des revenus du travail reste loin d'être satisfaisante. Certains organismes privés (syndicats belges, une association d'habitants de la région transfrontalière) disposent d'un large éventail de moyens d'information, mais ceux-ci sont le plus souvent réservés à leurs membres ou aux travailleurs frontaliers, sans toucher les petites entreprises et les indépendants, notamment. Quant aux administrations fiscales elles-mêmes, elles ne font pratiquement rien à cet égard.

Outre ces administrations fiscales, les employeurs et/ou les organismes de paiement des allocations/indemnités tels qu'associations professionnelles ou fonds de pension, interviennent au niveau de la perception de l'impôt. En pratique, cependant, pratiquement aucune collaboration ou concertation n'existe entre les diverses parties concernées. Enfin, les possibilités de procédures d'appel, éventuellement en justice, pour les travailleurs frontaliers individuels semblent, en pratique, difficilement envisageables.

Quelques recommandations d'action:

* En ce qui concerne l'application des traités fiscaux bilatéraux entre Les Pays-Bas, la Belgique et l'Allemagne, la situation des travailleurs frontaliers serait considérablement améliorée si l'employeur et les organismes prestataires concernés assumaient la responsabilité de la demande de dégrèvement du précompte ( la "déclaration du travailleur frontalier").

* En vue d'accroître la mobilité des travailleurs de l'Allemagne vers les Pays-Bas et la Belgique autant que des Pays-Bas vers la Belgique, il convient d'identifier les obstacles à ces mouvements pendulaires (potentiels). 
* Des mesures peuvent être envisagées en matière d'assistance juridique transfrontalière. On songe notamment, à cet égard, à une assistance individuelle aux travailleurs frontaliers dans leurs procédures en justice, à l'encouragement de procès-tests, à la promotion de l'accès à et de l'information sur les réglementations et la jurisprudence, etc.

* Une plus grande transparence de l'organisation de l'administration fiscale compétente pour les travailleurs frontaliers est sans doute possible en Belgique et en Allemagne.

* Les procédures administratives de mise en oeuvre devraient être soumises à des équipes transfrontalières chargées les rendre plus accueillantes pour le travail transfrontalier. Les Bureaux des Affaires belges et allemandes devraient être dotés à cette fin du personnel nécessaire.

\section{SÉCURITÉ ET PRESTATIONS SOCIALES}

En dépit de la coordination entre régimes nationaux de sécurité sociale instaurée par une Directive européenne, les navetteurs individuels sont toujours confrontés, dans la vie quotidienne, à des difficultés, essentiellement en matière frais de maladie, d'incapacité de travail, d'assurancevieillesse et de pensions. Ces problèmes sont imputables, d'une part aux principes de base différents sur lesquels sont fondés les divers systèmes nationaux de sécurité sociale et, d'autre part aux différences dans les critères d'entrée et de sortie, dans les niveaux d'indemnisation et d'allocations, etc.

Comme en matière fiscale, l'information insuffisante des travailleurs frontaliers concernés est à la base d'un grand nombre de difficultés. Ceci s'explique, non seulement par la complexité intrinsèque des réglementations, mais aussi par la rareté des endroits où il est possible d'obtenir une information et des conseils personnalisés en fonction des situations individuelles. S'y ajoute, comme facteur explicatif, une collaboration entre organes exécutifs, non seulement réduite mais souvent encore orientée vers la solution de problèmes nationaux. Ceci se traduit par des procédures inutilement longues, complexes et frustrantes pour le citoyen.

Quelques recommandations d'action:

* L'élaboration et la mise en oeuvre de nouvelles législations et réglementations continuent de tenir insuffisamment compte de l'impact de celles-ci sur les travailleurs transfrontaliers. Les responsables politiques et les groupes d'intérêt de l'Eurégion devront rester vigilants à cet égard.

* On s'efforcera de fournir beaucoup plus largement une information mieux orientée vers l'usager sur les conséquences du travail transfrontalier en matière de sécurité sociale.

* Les recommandations formulées en matière fiscale dans le sens de l'assistance judiciaire, de l'information et de l'amélioration des procédures administratives s'appliquent, bien entendu, également au domaine de la sécurité sociale.

\section{AXES D'ACTION D'NTÉRET GENERAL}

Outre les recommandations spécifiques à chacun des domaines décrits ci-dessus, le rapport propose également neuf principes de base susceptibles d'orienter la politique transfrontalière:

développement d'une approche de l'Eurégion en tant qu'entité administrative;

élaboration d'un cadre d'action motivant et innovateur;

- étude des facteurs de succès et d'échec de la collaboration transfrontalière;

- attention accrue aux travailleurs transfrontaliers potentiels; 
- attention accrue aux PME et indépendants;

- constitution de réseaux au sein de l'Eurégion autant qu'entre Eurégions;

- étude des possibilités d'une gestion par objectifs;

- élaboration d'un cadre juridique (administratif) d'insertion des projets de collaboration;

- attention accrue pour l'impact sur le travail transfrontalier des législations et réglementations nouvelles, notamment en matières de prestations sociales.

\section{EN ROUTE POUR UN MARCHÉ DU TRAVALL EURÉGIONAL}

La multiplicité des organisations qui oeuvrent à la réalisation d'un marché du travail eurégional peut s'avérer intéressante, pourvu qu'elle ne donne pas lieu à des doubles emplois ou à une dispersion d'initiatives non coordonnées.

En vue d'assurer une coordination allant au-delà de la simple juxtaposition d'efforts individuels, cinq orientations d'action s'imposent a priori à l'Eurégion Meuse-Rhin:

- élaboration d'une approche politique de ce qui est possible et souhaitable en matière de collaboration administrative au sein de la région;

- mise en place d'un cadre motivant et innovateur d'insertion des diverses actions plus concrètes;

- initiation de la constitution de réseaux au sein de l'Eurégion, par la mise en place d'un "Conseil Consultatif de l'Eurégion" et de groupes des travail thématiques composés de représentants des pouvoirs publics, des partenaires sociaux et des autres parties concernées (voir également Buck, 1990);

- allocation à des Fonds eurégionaux centraux de moyens financiers régionaux réservés aux domaines d'action prioritaires dans le cadre de la collaboration eurégionale;

- mise au point d'une politique d'information dynamique permettant à l'Eurégion Meuse-Rhin de se positionner, tant sur son territoire que face au monde extérieur.

Le groupe initiateur du Congrès eurégional pourrait inviter le Comité de concertation des Gouverneurs à prendre des initiatives dans les domaines suggérés ci-dessus.

Si les évolutions aux niveau national et communautaire ont, cela va de soi, un impact important sur la réalisation d'un marché du travail communautaire dans l'Eurégion Meuse-Rhin, la collaboration au sein de celle-ci peut, à son tour, contribuer de manière significative à la coopération européenne en général. En cela, les Eurégions assument une importante fonction de catalyseurs du processus de l'intégration européenne. 


\section{INLEIDING}

Het magische 'Europa zonder binnengrenzen' zal ongetwijfeld vooral door de bewoners van de grensstreken aan den lijve ondervonden moeten gaan worden of zoals de Europese Commissie (1990) zelf aangeeft: 'het is duidelijk dat de grensarbeiders bijzonder getroffen worden door de vertraging die bij de verwezenlijking van de doelstellingen van de Europese Gemeenschap kan optreden'. De problemen die zich ondanks alle voornemens voor de Europese integratie, nog dagelijks voordoen bij 'mensen van vlees en bloed', komen dan ook zeer sterk naar voren in één van de meest complexe Euregio's van Europa. In de Euregio Maas-Rijn komen niet alleen drie nationaliteiten bij elkaar, maar ook drie verschillende taal- en cultuurgebieden. Dat er echter ook grote mogelijkheden voor de Euregio Maas-Rijn zijn weggelegd, wordt onder meer geschetst in het rapport van de Commissie 'Toekomst Limburg' (Buck, 1990). In dit rapport wordt onder meer opgeroepen tot de ontwikkeling van een Euregionaal Deltaplan voor de arbeidsmarkt, waarbinnen de internationalisering van de arbeidsmarkt een belangrijke plaats zal moeten innemen.

In deze studie zal nader worden ingegaan op de knelpunten die zich momenteel voordoen met betrekking tot het functioneren van de Euregionale arbeidsmarkt. Tevens zal een aanzet worden gegeven tot het formuleren van beleidsinitiatieven die de totstandkoming van een Euregionale arbeidsmarkt dichterbij zouden kunnen brengen.

Alvorens in te gaan op de knelpunten op de Euregionale arbeidsmarkt en de beleidsinitiatieven ter verbetering van het functioneren van deze Euregionale arbeidsmarkt, is het goed eerst stil te staan bij het grote economische en maatschappelijke belang dat bewoners en bedrijven in grensregio's kunnen hebben bij een goed functionerende Euregionale arbeidsmarkt ${ }^{1}$. Daarbij kan een onderscheid worden gemaakt tussen enerzijds het belang van het wegnemen van de momenteel door pendelaars en bedrijven ondervonden nadelen van respectievelijk het werken en werven over de grens en anderzijds de voordelen van de schaalvergroting, die zal optreden door het samengaan van enkele perifere regionale arbeidsmarkten tot een grotere Euregionale arbeidsmarkt.

Het wegnemen van bestaande starheden op de Euregionale arbeidsmarkt betekent voor werkenden, werklozen en schoolverlaters uit de grensregio's een vergroting van hun ontplooiingskansen op de arbeidsmarkt. Voor arbeidsorganisaties vergroot een goed functionerende Euregionale arbeidsmarkt het wervingsgebied bij het aantrekken van nieuw personeel. Bovendien vergroot de Euregionale arbeidsmarkt het verzorgingsgebied van onderwijsinstellingen, arbeidsvoorzieningsorganisaties, e.d., waardoor deze een groter marktgebied krijgen. Een nevenprodukt van de Euregionale arbeidsmarkt is verder dat aan weerszijden van de nationale grenzen op meer efficiënte wijze gebruik kan worden gemaakt van de economische en sociale infrastructuur, met als gevolg dat deze infrastructuur ook aanmerkelijk zou kunnen worden verbeterd. Kortom, in feite hebben we hier te maken met de gebruikelijke voordelen van het wegnemen van rigiditeiten op de arbeidsmarkt in combinatie met de schaalvoordelen als gevolg van het opgaan van perifere regionale arbeidsmarkten in een grote Euregionale arbeidsmarkt.

Naast de economische voordelen die een Euregionale arbeidsmarkt zou kunnen bieden, is het goed om te benadrukken dat het opheffen van de knelpunten bij pendelarbeid ook onder meer een vereiste is, vanuit het principiële punt dat pendelaars binnen de Europese Gemeenschap het recht hebben, niet benadeeld te worden ten opzichte van de andere werkenden in het land waar men werkzaam is. Bovendien zou de vorming van Euregio's een belangrijke schakel kunnen vormen in het Europese integratieproces in het algemeen, omdat van de Euregio's een voorbeeldwerking kan uitgaan voor het aanbrengen van veranderingen in nationale instituties die

1. Indien in dit rapport wordt gesproken over de Euregio wordt gedoeld op de Euregio Maas-Rijn. 
het integratieproces belemmeren. Tenslotte kan het integratieproces ook in culturele zin worden versneld. Bij de vorming van Euregio's kan de (her)ontdekking van een goede buurman naast de verre vrienden binnen de eigen landgrenzen in dit vlak nieuwe perspectieven openen.

De probleemstelling van deze studie is in feite drieledig:

- het verkrijgen van inzicht in de knelpunten die momenteel optreden bij de internationale arbeidsmobiliteit binnen de Euregio;

- het in kaart brengen van de reeds bestaande initiatieven die gericht zijn op het opheffen of verminderen van de gesignaleerde knelpunten;

- het aangeven van de mogelijk te nemen beleidsinitiatieven waarmee een bijdrage kan worden geleverd aan het verbeteren van het functioneren van de Euregionale arbeidsmarkt.

In eerste instantie is een groot aantal publikaties, zoals rapportages van eerder onderzoek, brochures, beleidsnota's en knipselkranten, geïnventariseerd (zie hiervoor de bijgevoegde literatuurlijst). Het grootste deel van de onderzoekwerkzaamheden bestond echter uit het voeren van gesprekken met direct betrokkenen zoals (groepen van) pendelaars en vakbondsvertegenwoordigers, werkgevers en personeelsfunctionarissen en inhoudsdeskundigen zoals wetenschappers en ambtenaren belast met beleidsvoorbereiding of -uitvoering (zie bijlage I). Typerende uitspraken of praktijkvoorbeelden van bepaalde knelpunten zijn ter illustratie van de hoofdtekst in het rapport opgenomen.

Zowel bij het in kaart brengen van de knelpunten, als bij het schetsen van de mogelijk te nemen (beleids)initiatieven, zal telkens ten behoeve van de overzichtelijkheid, naast de meer algemene punten, een indeling plaatsvinden in een viertal themagebieden:

- arbeidsmarkt; onderwijs en scholing;

fiscus en financiën;

- sociale zekerheid en pensioenen.

Hoewel op het congres ook aandacht zal worden geschonken aan grensoverschrijdende investeringen valt dit onderwerp buiten het bestek van deze studie.

De verdere opzet van het rapport is als volgt. Eerst wordt in hoofdstuk 2 een globaal beeld geschetst van de arbeidsmarkt in de Euregio Maas-Rijn en de omvang van de huidige pendelstromen. Daarna komen in hoofdstuk 3 de knelpunten rondom pendelarbeid aan de orde. In dat hoofdstuk wordt aandacht geschonken aan de belangrijkste knelpunten die zich voor kunnen doen bij de vier door ons onderscheiden doelgroepen: pendelaars en potentiële pendelaars, werklozen en schoolverlaters aan de aanbodzijde van de arbeidsmarkt en werkgevers uit groot-, midden- en kleinbedrijf en zelfstandigen aan de vraagzijde van de arbeidsmarkt. Daarbij wordt in paragraaf 3.2. ingegaan op de knelpunten in de dataverzameling en informatievoorziening, waarna in paragraaf 3.3. de knelpunten themagewijs worden besproken. Vervolgens wordt in hoofdstuk 4 aandacht geschonken aan de inventarisatie van reeds bestaande activiteiten en beleidsinitiatieven die van belang kunnen zijn voor het verbeteren van het functioneren van de Euregionale arbeidsmarkt. In paragraaf 4.2. komen de terreinen waarop momenteel reeds actie wordt ondernomen themagewijs aan de orde. In paragraaf 4.3. worden enkele Euregionale initiatieven op het terrein van de voorlichting en enkele Euregionale scholingsprojecten nog nader belicht. In hoofdstuk 5 wordt eerst, in paragraaf 5.2., een aantal uitgangspunten geformuleerd voor het beleid ter verbetering van het functioneren van de Euregionale arbeidsmarkt. In paragraaf 5.3. wordt vervolgens een groot aantal aanbevelingen gedaan voor mogelijke beleidsinitiatieven. Tenslotte wordt in paragraaf 5.4. aangegeven welke belangrijkste eerste stappen binnen de Euregio Maas-Rijn moeten worden gezet om de totstandkoming van een Euregionale arbeidsmarkt te kunnen realiseren. 


\section{DE ARBEIDSMARKT IN DE EUREGIO MAAS-RIJN}

\subsection{LGGNG EN BEVOLKING}

De Euregio Maas-Rijn omvat op Belgisch grondgebied de provincies Luik en Limburg; in Nederland omvat het Zuid-Limburg en in Duitsland de districten Aken, Düren, Euskirchen en Heinsberg. De totale oppervlakte bedraagt ongeveer $11.000 \mathrm{~km}^{2}$.

Kaart 1. De Euregio Maas-Rijn

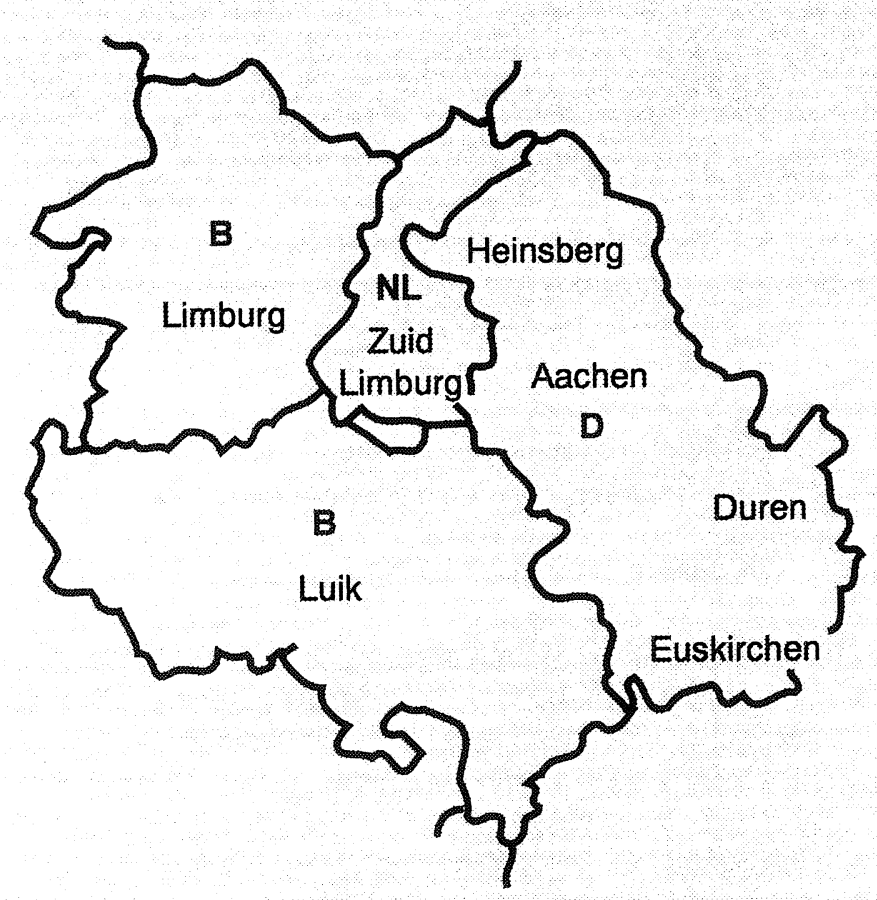

Bron: Goethals (1990)

In de Euregio wonen ruim 3,5 miljoen mensen. Het Duitse deel bevat 1,1 miljoen inwoners, de provincie Luik 1 miljoen en de beide Limburgse delen ruim 700.000 inwoners. Het Nederlandse deel is het dichtst bevolkt.

\subsection{ECONOMSCHE STPUCTUUR EN WERKGELEGENHEID}

Aan de Limburgse Sociaal-Economische Verkenning 1990 van het Economisch Technologisch Instituut Limburg (ETIL) ontlenen we de volgende tabel over de economische structuur en werkgelegenheid in de Euregio. 
Tabel 1. Sectorale werkgelegenheid, werkloosheid, Bruto Regionaal Produkt en werkgelegenheidsgroei

\begin{tabular}{|c|c|c|c|c|c|c|}
\hline & \multicolumn{3}{|c|}{$\begin{array}{l}\text { Werkgelegenheid, verdeling } \\
\text { naar sectoren (1987): }\end{array}$} & \multirow{2}{*}{$\begin{array}{l}\text { Werkloosh. } \\
\text { percent. } \\
\text { april } 1988 \\
\text { (geharm.) }\end{array}$} & \multirow{2}{*}{$\begin{array}{l}\text { Bruto } \\
\text { regionaal } \\
\text { produkt/ } \\
\text { inw.* (1986) }\end{array}$} & \multirow{2}{*}{$\begin{array}{l}\text { Groei werk- } \\
\text { gelegenheid } \\
\text { per jaar } \\
1985-1988\end{array}$} \\
\hline & landb. & nijverh. & dienst. & & & \\
\hline Provincie Limburg (B) & $3 \%$ & $41 \%$ & $56 \%$ & $10,8 \%$ & 94 & $2,6 \%$ \\
\hline Provincie Luik (B) & $3 \%$ & $29 \%$ & $68 \%$ & $12,7 \%$ & 97 & $0,5 \%$ \\
\hline Provincie Limburg (NL) & $5 \%$ & $35 \%$ & $60 \%$ & $10,3 \%$ & 91 & $3,7 \%$ \\
\hline Duitse deel Euregio ** & $4 \%$ & $38 \%$ & $59 \%$ & $7,0 \%$ & 89 & $1,4 \%$ \\
\hline
\end{tabular}

Bron: ETIL-SEV (1990)

* Het gemiddelde voor de gehele Europese Gemeenschap is daarbij op 100 gesteld.

** Het Duitse deel van de Euregio bestaat uit de districten Aken, Düren, Euskirchen en Heinsberg,

Belgisch Limburg wordt gekenmerkt door een relatief sterk aandeel van de nijverheid, met als de drie belangrijkste bedrijfstakken mijnbouw, transportmiddelen en metaal. De werkloosheid in deze provincie is relatief hoog. Daartegenover staat echter een relatief sterke groei van de werkgelegenheid.

De provincie Luik wordt gekenmerkt door een relatief sterk aandeel van de dienstensector. De belangrijkste industrietak is de metaal. De werkloosheid is hier evenals in Belgisch Limburg relatief hoog. De provincie Luik is overigens de Euregio Maas-Rijn de regio waar de werkgelegenheidsgroei tussen 1985 en 1988 het geringst is geweest.

Nederlands Limburg neemt wat de economische structuur betreft een tussenpositie in. Alleen de landbouw is relatief belangrijker dan in de overige regio's. De belangrijkste industriële bedrijfstakken zijn: chemie, hout/papier, steen/aardewerk/glas. De totale werkgelegenheid is na een relatief hoge werkloosheid, in het afgelopen decennium sterk gegroeid.

De industrie in het Duitse deel is nog sterker gediversifieerd dan in Nederlands Limburg. De belangrijkste industrietakken zijn: metaalbewerking en -verwerking, machinebouw, mijnbouw, hout en papier, steen/aardewerk/glas, electrotechniek, leder/textiel/kleding en de voedings- en genotmiddelenindustrie. De totale werkgelegenheid in deze regio is slechts licht gegroeid. De werkloosheid is hier echter het laagst van alle regio's.

\subsection{DE PENDELSTROMEN IN DE EUREGIO MAAS-RIN}

Er zijn geen betrouwbare cijfers beschikbaar over de omvang van de pendelstromen binnen de Euregio Maas-Rijn. De bestaande cijfers hebben de volgende tekortkomingen:

- de gebiedsafbakening komt niet overeen met die van de Euregio;

- het gebruik van verschillende databronnen (b.v. ziekenfondsen, arbeidsvoorziening, arbeidskrachtentellingen) levert afwijkende resultaten op (zelfs binnen één land);

- er is sprake van schattingen door het ontbreken van een verplichte centrale registratie.

De hier te presenteren cijfers moeten daarom gezien worden als een indicatie van de totale pendelomvang. 
In het algemeen is de pendelstroom in de Euregio oostwaarts gericht: er werken relatief veel Belgen in Nederland of Duitsland en veel Nederlanders in de Duitse grensstreken. Van het omgekeerde is veel minder sprake. Op basis van gegevens van het Nederlandse Centraal Bureau voor de Statistiek (CBS) heeft het ETIL het volgende overzicht van de pendelstromen tussen Limburg, België en Duitsland samengesteld. Daarbij moet worden bedacht dat deze CBSgegevens gebaseerd zijn op het aantal grensarbeiders dat bij de ziekenfondsen staat ingeschreven. De grensarbeiders die niet via een ziekenfonds verzekerd zijn, zijn derhalve niet in deze cijfers opgenomen.

Tabel 2. Ontwikkeling van de pendel tussen Nederlands Limburg en België en Duitsland, (cijfers 1 aprii)

\begin{tabular}{|c|c|c|c|c|c|c|}
\hline & 1985 & 1987 & & 1989 & & 1990 \\
\hline Pendel van Nederland naar Duitsland & 8322 & 8173 & $(8173)$ & 8290 & & 8620 \\
\hline Pendel van Duitsland naar Nederland & 518 & 594 & (829) & 590 & & 600 \\
\hline Pendelsaldo van Nederland met Duitsland, uitgaand & 7804 & 7579 & (7344) & 7700 & & 8020 \\
\hline Pendel van Nederland naar Belgiē & 870 & 815 & & 750 & {$[1127]$} & 810 \\
\hline Pendel van Bełgië naar Nederland & 5101 & 5853 & & 6460 & [10354] & 6470 \\
\hline Pendelsaldo van Nederland met Belgiè, inkomend & 4231 & 5038 & & 5710 & {$[9227$} & 5660 \\
\hline Pendel van België naar Duitsland & & & & & [3102] & \\
\hline Pendel van Duitsland naar België & & & $(313)$ & & [288] & \\
\hline Pendelsaldo van België met Duitsland, uitgaand & & & & & [2814] & \\
\hline Pendelsaldo Nederland t.o.v. België-Duitsland & 3573 & 2541 & & 1990 & {$[1527]$} & 2360 \\
\hline Pendelsaldo Duitsland t.o.v. België-Nederland & & & & $-105 \$ 4$ & & \\
\hline Pendelsaldo België t.o.v. Duitsland-Nederland & & & & 8524 & & \\
\hline Totaal Euregio Maas-Rijn & & & & 19480 & [20361] & \\
\hline
\end{tabular}

\section{Bron: ETILICBS}

(..) Data afkomstig van Landesamt für Datenverarbeitung und Statistik Nordrhein-Westfalen (LDS-NW *;

[..] Data afkomstig van Rijksinstituut voor Ziekte- en Invaliditeitsverzekering (RZI)**;

- In tegenstelling tot de CBS-data, die gebaseerd zijn op grensarbeiders ingeschreven bij het ziekenfonds, zijn de gegevens van het Landesamt afkomstig uit een volkstelling.

* afwijking moet toegeschreven worden aan een verschil in de onderzochte groep. Het Rijksinstituut is uitgegaan van de algemene inspectie van sociale zekerheid.

De cijfers illustreren duidelijk de oostwaartse beweging in de pendel. De pendel vanuit Nederlands-Limburg naar Duitsland is het meest omvangrijk (ruim 8.000 personen). Tussen 1985 en 1990 is dit aantal vrij stabiel gebleven.

De pendel vanuit België naar Nederlands Limburg is toegenomen van ruim 5.000 personen in 1985 tot 6.500 personen in 1990. Deze pendel is, gelet op de geringe pendelstroom vanuit Luik naar Nederland, waarschijnlijk vooral afkomstig van Belgisch Limburg. Volgens de van het RZI afkomstige data bedraagt de pendel van België naar Nederlands Limburg ruim 10.000 personen. Het grote verschil tussen de CBS en RZI-data illustreert het inadequate karakter van de metingen van de pendelstromen. 
De totale pendel vanuit Belgisch Limburg naar Duitsland bedroeg in 1981 volgens het Belgisch Nationaal Instituut voor de Statistiek 3.000 personen. Vanuit de provincie Luik bedroeg de pendel naar Duitsland 6.700 personen. De pendel vanuit Duitsland naar België bedraagt slechts enkele honderden personen. Volgens de secretaris van de dienst Grensarbeiders van de Confédération des Syndicats Chrétiens (CSC) in Eupen zijn er momenteel echter vanuit Belgisch Limburg hooguit 300 personen in Duitsland werkzaam en kunnen dit er nimmer 3.000 zijn geweest. Het totaal aantal Belgische pendelaars in Duitsland bedraagt volgens deze secretaris momenteel circa 3.500 à 4.000. Volgens een opgave van het Duitse Ministerie van Financiën zijn er circa 3.400 Belgen in Duitsland werkzaam, (Finanz Min., 1990). Uit deze cijfers blijkt overigens ook dat er vanuit Duitsland circa 100 personen in België werkzaam zijn.

Rekening houdend met het feit dat de gebiedsafbakening in de bovengenoemde cijfers breder is dan die van de Euregio, kan de totale omvang van de pendelstromen binnen de Euregio MaasRijn geschat worden op 15 tot 25 duizend personen. Op een (geschatte omvang van de) beroepsbevolking van ongeveer 1,5 miljoen, betekent dit dat 1 à 2 procent van de beroepsbevolking pendelt binnen deze Euregio.

Over deze pendelaars, wie ze zijn en waar ze werken is vrij weinig bekend. Het Hoger Instituut van de Arbeid (Goethals, 1990) geeft aan dat de grensarbeiders vanuit België naar Nederland werkzaam zijn in een groot aantal verschillende sectoren: industrie en openbare nutsbedrijven, bouwmaterialen, aardewerk- en glasindustrie, electronische industrie, transportmiddelenindustrie, hotel- en restaurantwezen, handel en overige dienstverlening.

Helaas ontbreken op het niveau van de Euregio elementaire sociaal-economische statistieken en kernindicatoren ten aanzien van het functioneren van de arbeidsmarkt. De huidige arbeidsmarktcijfers zijn erg globaal en hebben of op een breder gebied betrekking of zijn onderling onvoldoende vergelijkbaar door afwijkende classificaties, meetinstrumenten en databronnen. 


\section{KNELPUNTEN RONDOM GRENSARBEID}

\subsection{INLEIOING}

Voordat nader zal worden ingegaan op de knelpunten die zich voordoen rondom grensarbeid, is het goed om eerst eens stil te staan bij de mogelijke voordelen verbonden aan pendelarbeid. Mogelijke voordelen van grensarbeid kunnen liggen in de kleinere afstand tot het werk, een betere kwaliteit van de arbeid of betere arbeidsvoorwaarden, zoals een hogere beloning, een vaste arbeidsplaats of betere carrière- of scholingsmogelijkheden. Een bijzondere categorie pendelwerknemers ontstaat indien men vanuit voordeelsoverwegingen in het aangrenzende buitenland gaat wonen. Het voordeel kan dan onder meer ontstaan door de aantrekkelijkheid van fiscale regelingen, woon- en levenslasten en andere factoren die de woonplaatskeuze bepalen. Een bijzondere categorie pendelaars ontstaat daarnaast door "Euregionale" huwelijken.

Pendelarbeid kan ook het gevolg zijn van het ontbreken van een passende arbeidsplaats in het eigen land. Het verruimen van de blik tot over de landsgrenzen heeft het in dit geval mogelijk gemaakt werk te kunnen vinden. Een beperkt onderzoek van Goethals (1990) onder Belgische pendelaars wijst er op dat het met name de beschikbaarheid van werk is waardoor men zich gaat oriënteren op de buitenlandse arbeidsmarkt. De helft van de ondervraagden zegt een baan in België te zullen aannemen, indien die mogelijkheid zich zou voordoen. Het motief daarbij is niet alleen dat het dichterbij is, maar ook dat dan alle moeilijkheden met papieren zouden wegvallen.

\section{Knelpunten: voor wie en wanneer?}

Bij het beschrijven van knelpunten kan de pendelrichting een rol van belang spelen. De pendelstroom beweegt zich, zoals reeds werd aangegeven, globaal gezien oostwaarts. Dit is zichtbaar in de mate waarin knelpunten in eerdere studies in kaart zijn gebracht: de gevolgen van enerzijds het wonen in België en het werken in Nederland en anderzijds het pendelen van Nederland naar Duitsland zijn goed in beeld gebracht. Er zijn daarentegen geen rapporten of brochures aangetroffen waarin de nadelige gevolgen van de omgekeerde pendel worden geïnventariseerd.

Naast het onderscheid naar de pendelrichting kan het van belang zijn om bij de knelpunten een onderscheid te maken tussen de feitelijke en de potentiële pendelaars. Vanuit de vraag in hoeverre de internationale arbeidsmobiliteit binnen de Euregio wordt belemmerd, is het vooral van belang de aandacht te richten op de potentiële pendelaars. Daarbij kan men zowel denken aan werkenden als aan werklozen, herintreders en schoolverlaters. Bovendien kan men een onderscheid maken tussen degenen die op zoek zijn naar een baan (loontrekkenden) en degenen die zich als zelfstandige zouden willen vestigen.

Voor een goed overzicht van de knelpunten die kunnen optreden ten aanzien van de Euregionale arbeidsmarktmobiliteit moet echter niet alleen gekeken worden naar de potentiële pendelaars. Immers, ook vanuit de vraagkant van de arbeidsmarkt kunnen diverse factoren de mobiliteit belemmeren, als gevolg waarvan arbeidskrachten niet in de buurlanden willen of kunnen gaan werken. Daarnaast is het zinvol om de feitelijke problemen aan te geven, waarmee degenen die wel pendelen worden geconfronteerd. Tenslotte is het nuttig om te wijzen op de specifieke (informatie-)problemen waarmee 'intermediaire' organisaties, die een rol kunnen spelen bij de afstemming van vraag en aanbod op de arbeidsmarkt, worden geconfronteerd. Overigens moet worden opgemerkt dat een aantal knelpunten een enigszins subjectief karakter heeft. Zo zal éénzelfde regeling niet voor alle betrokkenen tot dezelfde 'knelpuntsituaties' leiden. 
Aan het eind van dit hoofdstuk wordt in schema 1 een globaal overzicht gegeven van de belangrijkste knelpunten zoals die worden envaren door de in dit rapport onderscheiden doelgroepen. De belangrijkste knelpunten zijn daarbij ingedeeld in de vier in hoofdstuk 1 genoemde themagebieden: arbeidsmarkt, onderwijs en scholing, fiscus en financiën en sociale zekerheid en pensioenen. Daarnaast worden nog de knelpunten aangeduid die zich voordoen op het infrastructurele vlak, e.d. De verdere opzet van dit hoofdstuk is als volgt. In paragraaf 3.2. worden de knelpunten aangegeven die zich voordoen in de dataverzameling en informatievoorziening, waarna in paragraaf 3.3. de in schema 1 globaal aangeduide knelpunten meer uitvoerig zullen worden besproken. Daarbij wordt achtereenvolgens ingegaan op de bovengenoemde vier themagebieden.

\subsection{KNELPUNTEN IN DE DATAVERZAMELING EN INFORMATIEVOORZIENING}

\section{Behoefte aan informatie m.b.t. knelpunten en mogelijkheden op de arbeidsmarkt}

Zoals in hoofdstuk 2 reeds werd aangegeven, bestaat er een groot gebrek aan informatie over de omvang, herkomst, samenstelling en bestemming van pendelarbeid in de Euregio Maas-Rijn. Statistisch materiaal over de Euregionale arbeidsmarkt is niet alleen van belang voor beleidsontwikkeling door de verschillende overheden en een efficiënte bemiddeling door arbeidsvoorzieningsorganisaties, maar ook voor het bedrijfsleven. Uit een recent onderzoek van KPMG, Klynveld Management Consultants (KPMG, 1991) blijkt dat Limburgse bedrijven, in het bijzonder in de produktiesector, behoefte hebben aan (Eu)regionale arbeidsmarktinformatie. Dit signaal wordt veelal onderschreven in de gesprekken die zijn gevoerd met hoofden personeelszaken van bedrijven en personen werkzaam in de sfeer van arbeidsvoorziening en personeelsbemiddeling.

Daarbij gaat het bijvoorbeeld om de vraag-aanbod verhoudingen op de arbeidsmarkt en salarisgegevens per sector, beroep, opleiding en subregio. Voor bedrijven zouden deze gegevens gebruikt kunnen worden voor het personeelsbeleid op (sub)regionaal niveau in het algemeen en de personeelswerving, het beloningsbeleid en het eventuele outplacementbeleid in het bijzonder. Voor de arbeidsvoorzieningsorganisaties is een gedetailleerd doch overzichtelijk inzicht in de vraag-aanbod verhouding in de aanliggende grensregio's van belang. Met name wanneer deze vraag-aanbod verhoudingen in kwalitatief of kwantitatief opzicht wezenlijk afwijken van die in de eigen regio is verder onderzoek naar specifieke vacatures en/of aanvullende scholingsmogelijkheden van groot belang.

\section{Behoefte aan informatie m.b.t. mobiliteitsbelemmerende factoren}

Uit de gevoerde gesprekken bij enkele relatief grote bedrijven die reeds gebruik maken van pendelarbeid, blijkt dat men geen extra ondersteuning nodig zegt te hebben bij de werving, aanstelling en begeleiding van buitenlandse grensarbeiders. Dankzij ervaring, de kennis die aanwezig is bij reeds werkzame grensarbeiders en de capaciteit die grotere bedrijven hebben om snel de benodigde informatie te achterhalen bij de desbetreffende instanties, doen zich, voor deze bedrijven althans, niet al te veel problemen voor. Uit gesprekken die vervolgens met de werknemers/pendelaars zijn gevoerd blijkt overigens dat de informatieverstrekking van bedrijven aan pendelende werknemers doorgaans nog sterk tekortschiet. 
In het kader van een grote reorganisatie is begin 1991 een complete afdeling van Philips Eindhoven met circa 50 werknemers (Nederlanders en Belgen) overgeplaatst naar Aken in Duitsiand. Na herhaalde verzoeken van de werknemers werd door de Afteling Personeelszaken van het Nederlands bedrijf voor de overplaatsing een voorlichtingsavond georganiseerd met sprekers van verschillende Nederlandse en Duitse instanties, waaronder de Duitse Krankenkasse, het Zlekenfonds Venlo, de Duitse belastingdienst, het Duitse staatspensioenfonds en de Dienst Personeelszaken van de betreffende buitenlandse bedrijsvestiging. Deze voorlichtingsavond maakte volgens de werknemers eén ding duidelijk en wel dat de gevolgen erg gecompliceerd waren en bovendien afhankelijk zouden zijn van leders individuele situatie en voorkeuren. Daardoor konden er nauweliks algemene richtlinen worden gegeven. De tijens het groepsgesprek door ons getoonde brochures van bijoorbeeld de Vereniging Europese Grenslandbewoners NEG). Algemeen Christelijk Vakverbond (ACV) of de Bureaus voor Belgische-en Duitse Zaken waren onbekend en bleken in een grote informatiebehoefte te voorzien.

Hieruit zouden verschillende conclusies kunnen worden getrokken:

- de informatieavond leidde tot verwarring en een toegenomen weerstand tegen de opgelegde bedrijfsverplaatsing. Door een riante pendelvergoeding voor de eerste jaren werd deze weerstand gedeeltelijk weggenomen;

- zelfs een grote, internationaal opererende onderneming is blijkbaar niet op de hoogte van de meest relevante voorlichtingsorganisaties en het beschikbare informatiemateriaal;

- de uitgenodigde instanties zijn vooral betrokken bij de uitvoering van de regelgeving en daardoor in zekere zin belanghebbenden. Deze organisaties zijn echter doorgaans nauwelijks ingesteld op informatieverstrekking en hebben derhalve niet of nauwelijks de beschikking over begrijpelijke en op de informatiebehoefte van (potentiële) pendelaars afgestemde brochures;

Bovenstaande waarnemingen worden onderschreven door het volgende: In de Banenkrant, een bijlage van het huisaan-huis advertentieblad "Zondagnieuws", van 5 oktober jl. stond een interview met een vertegenwoordiger van de Vereniging van Europese Grenslandbewoners (VEG). Binnen drie dagen had deze VEG-vertegenwoordiger meer dan 20 verzoeken om informatie gekregen, hoewel in het interview alieen voor-en achternaam en woonplaats vermeld werden.

Het vermoeden lijkt gerechtvaardigd te zijn dat het vooral het Midden- en Klein bedrijf en de zelfstandigen zijn, die het vaak ontbreekt aan specifieke deskundigheid met betrekking tot de knelpunten en mogelijkheden van het aanstellen van werknemers uit buurlanden.

Het ontbreken van specifieke deskundigheid geldt nog sterker voor de (potentiële) pendelaar. Verwacht mag worden dat het overgrote deel van de beroepsbevolking in de Euregio weliswaar direct of indirect bekend is met het fenomeen pendelarbeid. Er is echter maar een zeer beperkt aantal deskundigen dat bekend is met alle mogelijke fiscale- en sociaal-rechtelijke gevolgen die daarmee verbonden kunnen zijn.

Ten aanzien van het beschikbare schriftelijke informatiemateriaal over de fiscale- en sociaaljuridische gevolgen van pendelarbeid kan het volgende worden geconcludeerd:

- er is relatief veel schriftelijke informatie beschikbaar over de belangrijkste fiscale- en sociaaljuridische gevolgen van de pendelarbeid van België naar Nederland of Duitsland en van Nederland naar Duitsland. Deze informatie is echter op relatief weinig plaatsen verkrijgbaar. Bovendien is dit materiaal in de meeste gevallen opgesteld ten behoeve van intern, ambtelijk gebruik of direct samengesteld op basis van ambtelijke stukken, waardoor het materiaal niet erg geschikt is voor het geven voorlichting. Een uitzondering moet hierbij gemaakt worden voor de door het Benelux-bureau samengestelde brochures voor Nederlandse- en Belgische pendelaars, en voor de Vlaamse ACV en de Waalse CSC die voor de Belgische pendelaars naar Nederland en Duitsland zeer handzame brochures hebben samengesteld. De Vereniging Europese Grenslandbewoners (VEG) verstrekt zeer toegankelijke informatie voor Nederlandse pendelaars naar Duitsland; 
- er is nauwelijks schriftelijke informatie beschikbaar over de gevolgen van het wonen in Duitsland en het werken in België of Nederland; en er is relatief weinig informatie beschikbaar over het wonen in Nederland en het werken in België;

- de beschikbare schriftelijke informatie beperkt zich veelal tot een (gebruikersonvriendelijke) vergelijking van de fiscale en sociaal-rechtelijke regelingen. Van 'information mapping', dat wil zeggen het 'menugewijs' aanbieden van korte 'informatieblokken', wordt nog geen gebruik gemaakt;

- er lijkt sprake te zijn van gescheiden circuits van informatieverstrekking vanuit een aantal verschillende betrokken instanties: vakbonden, arbeidsvoorziening en particuliere initiatieven. Een dergelijke verbrokkeling maakt het enerzijds onduidelijk waar men voor een bepaalde informatievraag het beste terecht kan en belemmert anderzijds een geïntegreerd voorlichtingsbeleid.

Een ambtenaar van het Ministerie van Sociale Zaken en Werkgelegenheid merkte hierover op: 'Als er één ding is waarmee je op korte termijn kunt scoren dan is het wel de voorlichting. Die is nog erg divers en versnipperd langs de grenzen. Echte deskundigheid is bovendien erg schaars'.

\subsection{KNELPUNTEN NAAR THEMACEBIED}

\subsubsection{Arbeidsmarkt}

Baanzoekende werknemers oriënteren zich op hun arbeidsmarktmogelijkheden op basis van een scala aan mogelijke informatiebronnen, variërend van radio, t.v. en dagbladen, personeelsadvertenties in de lokale media, directe informatie van werkgevers, de arbeidsbureaus en de particuliere arbeidsbemiddelings- en uitzendbureaus. Ook het 'van-horen-zeggen-circuit' speelt bij deze oriëntatie een belangrijke rol.

Voor werkgevers is kennis van de relevante lokale en regionale arbeidsmarktsegmenten van groot belang voor een effectieve personeelswerving. Daarvoor staan min of meer dezelfde publieke informatiebronnen ter beschikking als voor de baanzoekende werknemer, zij het dat verwacht mag worden dat werkgevers deze informatiebronnen vaker en op een meer intensieve en meer professionele wijze zullen gebruiken. In de grensstreken blijkt het aantal mogelijke instrumenten om zich te oriënteren op de arbeidsmarktmogelijkheden 'over de grens', echter beperkt te zijn. De grens blijkt daarnaast niet alleen nog als een fysieke kering te fungeren voor de informatiedragers (lokale media, het kennissen-circuit) maar ook voor de begrijpelijkheid van de informatie (omschrijving van de vacature, kwalificatie-eisen, e.d.).

In het verleden hebben werkgevers in bijvoorbeeld de bouw en de industrie op deze problemen een antwoord gevonden door een actief recruteringsbeleid over de grens te voeren. Met zittingsdagen in het plaatselijke café en door een fiks handgeld ter beschikking te stellen, werden de benodigde arbeidskrachten geronseld. Tegenwoordig is echter het scala aan beroepen, beroepskwalificaties, opleidingen en getuigschriften aanzienlijk toegenomen. Bovendien zijn de allocatiemechanismen en -procedures tussen vraag en aanbod op de arbeidsmarkt in veel gevallen formeler en complexer geworden.

Ondanks de sterk toegenomen complexiteit van de grensoverschrijdende personeelswerving, arbeidsbemiddeling en sollicitatiemogelijkheden, zijn de daarvoor benodigde informatiemogelijkheden zeer gering gebleven. Daarbij dient opgemerkt te worden dat de motivatie voor de werknemer om zich over de grens te oriënteren op een mogelijke baan, in de loop der jaren is 
afgenomen, ongetwijfeld mede omdat het stelsel van fiscus en sociale zekerheid steeds ingewikkelder is geworden. Met uitzondering van een kleine groep pendelaars, voor wie het desondanks financieel aantrekkelijk is om over de grens te werken, is het echter voor het merendeel van zowel werkgevers, als werknemers, vooral uit noodzaak wanneer men in het nabije buitenland gaat werven of solliciteren.

Belemmeringen die een kwantitatief inzicht in de arbeidsmarktsituatie in de aangrenzende regio's in de weg staan, liggen in het ontbreken van een uniforme en gedetailleerde verzameling van arbeidsmarktgegevens. Daarvoor is de ontwikkeling van een uniform coderings- en classificatiesysteem voor bedrijven, beroepen en opleidingen noodzakelijk. De door het International Labour Office (ILO) ontwikkelde standaardclassificaties zijn weliswaar sterk verouderd doch kunnen hiervoor wel als basis dienen.

Welke problemen komen de individuele, personeelzoekende werkgever en de in het nabije buitenland wonende, baanzoekende (potentiële) werknemer tegen, indien zij naar elkaar op zoek zijn? Voor het beantwoorden van deze vraag is het nuttig de mogelijk belemmerde factoren in te delen naar een drietal fasen waarin het allocatieproces op de arbeidsmarkt kan worden opgedeeld:

\section{Oriëntatiefase:}

- werknemers zijn onvoldoende op de hoogte van de inhoud van de voor hen interessante vacatures in de aangrenzende regio's;

- met name het midden- en kleinbedrijf is onbekend met de aard van de aangeboden kwalificaties in de buurlanden;

- werkgevers en werknemers zijn niet exact op de hoogte van de lokale arbeidsmarktsituatie 'over de grens'.

\section{Zoekfase:}

- verspreidingsgebied van lokale kranten kent vrij strikte begrenzing;

- bij werkgevers ontbreekt de kennis over advertentiemogelijkheden (adres, contactpersonen, tarieven) en het te verwachten rendement in media in het aangrenzende buitenland;

- media zijn huiverig om advertenties van onbekende, buitenlandse adverteerders op te nemen: veelal is contante betaling verplicht.

\section{Contactfase:}

- werkgevers kunnen de aangeboden kwalificaties van buitenlandse referenten niet op hun juiste waarde schatten.

Overigens moet worden opgemerkt dat literatuur of empirische gegevens over personeelswerving en solliciteren over de grens tot op heden ontbreekt. In het recente rapport 'Trends en ontwikkelingen in Human Resource Management in Limburg', van KPMG Klynveld Management Consultants (KPMG 1991) komt dit aspect nauwelijks aan de orde. Wel wordt in dit rapport gewag gemaakt van de grote behoefte bij bedrijven uit de industrie en de produktiesector aan vergelijkbare salarisgegevens voor het technisch personeel.

In een recentelijk afgesloten onderzoek van het Nederlands Economisch Instituut (NEI) in opdracht van het Centraal Bureau voor de Arbeidsvoorziening (CBA, 1991) naar de internationale arbeidsbemiddeling komen de onderzoekers tot de conclusie dat de bestaande pendelarbeid voornamelijk tot stand is gekomen door een aktie van een werkgever of een werknemer. De Nederlandse overheidsdiensten en arbeidsvoorzieningsorganisaties spelen bil het bevorderen van een vrij verkeer van werknemers slechts een geringe rol. Hoewel de arbeidsbureaus in de grensstreek daarentegen wel grensoverschrijdende activiteiten ontwikkelen, blijkt van een gestructureerde vorm van samenwerking nog nauwelijks sprake te zijn. 
De arbeidsbemiddeling aan weerszijden van de grens heeft veelal plaats door middel van grensoverschrijdende contacten en uitwisseling van informatie. Deze informatie-uitwisseling blijkt op enkele plaatsen redelijk succesvol te zijn. De geautomatiseerde vacature-uitwisseling tussen arbeidsbureaus via de uitwisselingsprogramma's SEDOC en JET verloopt daarentegen nog steeds stroef. Problemen doen zich onder meer voor omdat de nationale stelsels van vacatureregistratie onderling niet compatibel zijn. Hierdoor moeten de buitenlandse vacatures steeds opnieuw handmatig ingevoerd worden. Bovendien lijkt de 'trefkans' voor een geslaagde bemiddeling beperkt te zijn, indien niet ook inzicht wordt gegeven in de vraag-aanbod verhoudingen aan de andere zijde van de grens. Een derde belemmering is het ontbreken van een toegankelijk informatiesysteem voor de diplomavergelijking. De behoefte aan een dergelijk informatiesysteem zal zich voordoen bij een grootschalige geautomatiseerde vacatureuitwisseling.

Eind 1990 werd de meubelfabriek Enve Polstermöbel uit het Duitse Erkelens, circa 40 kilometer van Sittard, geconfronteerd met de mogelijkheid van een grote order. Daardoor zou er op korte termijn een groot aantal ongeschoolde vakkrachten nodig zijn. Het Arbeitsamt Erkelens kon hiervoor in de direkte omgeving niet genoeg mensen krijgen. Een bemiddelaar van het Arbeidsbureau Sittard kwam dit min of meer toevallig ter ore. Deze nam contact op met het Arbeitsamt Erkelens en het meubelbedrijf en had vervolgens in korte tijd een 25-tal geinteresseerden gevonden. Voor het vervoer werd een busdienst ingesteld. Op het laatste moment werd de actie echter vanuit het bedrijf afgeblazen: de order was niet doorgegaan. Begin 1991 werd het Arbeidsbureau Sittard benaderd door een zakenman uit Geleen. Deze wilde in een fabriekshal in Geleen een bedrijf opzetten voor de preparatie van armaturen voor leren bankstelten. De afwerking zou plaats vinden bij Ervie Postermöbel in Erkelens die inmiddels toch weer om personeelsleden verlegen leek te zitten. Het plan van de Geleense zakenman bleek echter niet haalbaar: aan de grens zou per bankstel een dermate hoge borgsom aan de douane betaald moeten worden dat dit bedrijfseconomisch niet verantwoord was. Niettemin zou or een gesprek plaatsvinden tussen de nieuwe bedrifsleider van Polstermöbel, het Arbeitsamt Erkelens en het Arbeidsbureau Sittard. Eerstgenoemden kwamen daar echter niet opdagen. Volgens het Arbeitsamt Erkelens omdat men door bedrifsorganisatorische maatregelen met minder mensen kon volstaan. Volgens de nieuwe bedrijfsleider omdat er vanuit Nedertand nauwelijks reacties waren gekomen op een wervingsadvertentie.

\subsubsection{Onderwijs en scholing}

Een in het provinciaal onderwijsbeleid uitstekend ingewijde deskundige maakte melding van het grote aantal Limburgse jongeren uit Nederlands Limburg dat nu reeds om 'kwaliteitsredenen' een reguliere opleiding in België bezoekt. Zo zou de Heilig Hartschool te Maasmechelen (B) momenteel bezocht worden door circa 400 Nederlandse jongeren.

Hoewel grensbewoners volgens het Verdrag van Rome niet geweigerd kunnen worden tot een (beroeps)opleiding in een naburig EG-land is er nog een groot aantal factoren waardoor het volgen van een opleiding over de grens wordt bemoeilijkt. Een tweetal knelpunten staat daarbij centraal:

- er is geen afstemming van de opleiding op de behoeften aan de andere kant van de grens;

- men heeft geen toegang tot de onderwijsstelsels in de buurlanden.

Bovendien ontbreekt het nog aan een toegankelijk overzicht van de vraag naar en het aanbod van opleidings- en scholingsmogelijkheden en de daarvoor geldende vooropleidingseisen. Ook doet zich een omvangrijk probleem voor op het gebied van de erkenning van diploma's, al bestaat er thans wel een algemene richtlijn voor de erkenning van hoger-onderwijsdiploma's (universitaire- en beroepsopleidingen van tenminste drie jaar). 
In Nederland heeft de organisatie van de diplomavergelijking overigens een enigszins versnipperd karakter doordat verschillende instanties bil de uitvoering hievan zïn betrokken: de sectie studievergelijking van het NUFFIC, de Informatiseringsbank te Groningen, het Ministerie van Economische Zaken (in het kader van de vestigingswetgeving) en het Centraal Bureau voor de Arbeidsvoorziening (CBA) (in verband met de arbeidsbemiddeling en scholingsactiviteiten).

Een deskundige maakte melding van de nieuwbouw, van een opleidingscentrum voor CNC-installaties in Nederland. Het betrof een zeer omvangrijke investering. Niet lang daarna bleek dat er omstreeks dezelfde tijd enkele tientallen kilometers over de grens eveneens een nieuw en praktisch vergelijkbaar opleidingscentrum was neergezet.

Ook wordt door CEDEFOP, Berlijn nog gewerkt aan de vergelijkbaarheid van getuigschriften van vakbekwaamheid van onder andere het leerlingwezen. Hoewel het punt van diploma-vergelijking en getuigschriften vaak genoemd wordt als een belangrijk knelpunt voor grensoverschrijdende arbeid, wordt dit niet onderschreven door degenen waarmee door ons is gesproken: noch de pendelaars zelf, noch de (grotere) bedrijven zeggen hiermee veel last te hebben (gehad). Niettemin zou het een belangrijk obstakel kunnen vormen voor potentiële pendelaars en hun mogelijke werkgevers (met name voor het midden- en kleinbedrijf en zelfstandigen).

\subsubsection{Fiscus en financiën}

Op Europees niveau spelen op het terrein van de persoonlijke belastingheffing twee kwesties een belangrijke rol. Ten eerste, de competentie-kwestie tussen de Europese Commissie enerzijds en de Raad van Ministers en nationale overheden anderzijds. De Commissie heeft in het verleden verschillende malen getracht om op het terrein van de direkte, persoonlijke belastingen, via een voorstel voor een Richtlijn of Verordening op te treden. Tot op heden hebben de nationale overheden dit echter kunnen tegenhouden, onder verwijzing naar het Europees Verdrag waarin de soevereiniteit van de lidstaten op het terrein van de direkte belastingheffing, wordt erkend. Als gevolg van de gestage ontwikkeling van het Europees Gemeenschapsrecht waarbij de jurisprudentie een belangrijke rol speelt, ontkwamen de Commissie en de lidstaten echter niet aan een voortdurende herbezinning over de taakverdeling op het terrein van direkte belastingheffing. Sinds kort is dit echter een officieel taakgebied van de Europese Commissie, zodat gewerkt zou kunnen gaan worden aan coördinerende wet- en regelgeving.

Ten tweede speelt de kwestie of de (persoonlijke) belastingheffing plaats dient te vinden in het woonland of in het werkland. Het woonland, dat volgens de algemene rechtsbeginselen het belastingrecht heeft, heeft bij pendelaars echter niet de mogelijkheid om de loon- of inkomstenbelasting aan de bron op te leggen. In het algemeen wordt er daarentegen thans wel in het werkland een belasting op het inkomen geheven. Het belastingverdrag tussen België en Nederland is hierop een uitzondering.

In 1979 is door de Europese Commissie een voorstel voor een Belasting-Richtlijn ingediend. Hierin wordt voorgesteld om de inkomsten van grensarbeiders te belasten in het woonland. Indien in het werkland belastingheffing aan de bron plaatsvindt dient een verrekening met het woonland plaats te vinden. Het voorstel is echter vanaf 1986 in de Raad van Ministers geblokkeerd, omdat de meeste lidstaten van mening zijn dat dit probleem geregeld moet worden aan de hand van bilaterale verdragen. Het zijn met name de grotere landen zoals Duitsland en Frankrijk die zich tegen de voorgestelde Richtlijn verzetten omdat dit voor hen een groot inkomensverlies zou betekenen. Met de inkomstenbelasting van bijvoorbeeld Nederlandse pendelaars in Duitsland is 
volgens een schatting van het Duitse Ministerie van Financiën een bedrag van 100 miljoen DM. gemoeid (Finanz Min.,1990). Daarnaast zijn er enkele regionale vakverenigingen die zich tegen het voorstel verzetten.

Als gevolg van deze patstelling op Europees niveau is de Commissie genoodzaakt tot het ontwikkelen van een nieuwe Belasting-Richtlijn voor de lidstaten. Tot die tijd zullen de verschillen in uitgangspunten en de achterstelling van pendelaars in de nationale belastingwetten waarschijnlijk blijven voortbestaan. De commissie heeft tot die tijd alleen de mogelijkheid om inbreukprocedures in te stellen tegen lidstaten die pendelaars benadelen ten opzichte van eigen ingezetenen. Voor pendelaars bestaat de mogelijkheid om deze gelijkheid af te dwingen door juridische procedures tot aan het Europese Hof van Justitie. De juridische mogelijkheden hiervoor zijn in ieder geval aanzienlijk toegenomen nu het Hof via een recent arrest (8 mei 1990, zaak $175 / 88$ ) heeft vastgelegd dat het beginsel van gelijke behandeling ook geldt voor de inkomstenbelasting. Blijft wel dat een individuele pendelaar over een groot uithoudingsvermogen en zelfvertrouwen moet beschikken, om een dergelijk juridisch proces tot het eind toe te doorlopen.

Voor een goed overzicht van de problemen die zich voordoen op het terrein van de fiscale wetgeving bij de belangrijkste bestaande pendelstromen zal achtereenvolgens worden ingegaan op de pendelstromen van Nederland naar Duitsland, van België naar Nederland en van België naar Duitsland. Daarna wordt kort ingegaan op specifieke knelpunten in het betalingsverkeer.

\section{Specifieke fiscale problemen tussen Duitsland en Nederland}

Het Duits-Nederlandse Verdrag van 1959 wijst het heffingsrecht toe aan het werkland. Het Verdrag bevat geen afzonderlijke regelingen voor grenspendelaars. Nederland verleent, als woonland van de Nederlandse pendelaars in Duitsland, ter voorkoming van dubbele belasting een vrijstelling van het betalen van inkomstenbelasting over het Duitse inkomen. In het Aanvullend Protocol uit 1980 (op het Verdrag van 1959) is de werkstaatheffing aangevuld met een aantal bepalingen waardoor pendelaars voor dezelfde tegemoetkomingen in aanmerking komen als de inwoners van het werkland.

De voorwaarde daarvoor is echter dat de inkomsten waarover de werkstaat het recht tot belastingheffing heeft ten minste $90 \%$ bedragen van het gezinsinkomen van de grensarbeider. Hoewel de fiscale positie van de grensarbeider aanzienlijk verbeterd is door dit Aanvullend Protocol, ondervinden grensarbeiders die in Nederland wonen en in Duitsland werken nog steeds een aantal benadelingen (Euregio, 1989).

Deze problemen concentreren zich rondom de volgende punten:

- benadelingen in Nederland voor werknemers in Duitsland die in Nederland wonen. Zo zijn er voor alleenstaande ouders problemen met betrekking tot de belastbaarheid van de kinderbijslag en ondervinden alleenstaanden problemen bij de aftrekbaarheid van de oudedagsvoorziening;

- benadelingen in Duitsland voor werknemers in Duitsland die in Nederland wonen. Problemen doen zich hierbij onder meer voor bij de aftrekbaarheid van hypotheekrente. Ook de indeling in tariefgroepen veroorzaakt problemen. Zo komen de part-time pendelaar, de pendelaar met bijverdiensten in het woonland, alsmede degene die niet het gehele jaar als pendelaar heeft gewerkt, automatisch in de hoogste Steuerklasse terecht. De genoemde personen komen tevens niet in aanmerking voor de 'Lohnsteuer-Jahresausgleich', zij kunnen de Vorsorgeauswendungen niet voor de feitelijke hoogte opvoeren en kunnen tevens geen 'aussergewöhnliche Belastungen' of giften en bijdragen aftrekken;

- benadelingen voor zelfstandigen die in Nederland wonen en in Duitsland werkzaam zijn. Deze worden altijd in de hoogste Steuerklasse ingedeeld en kunnen voor de inkomstenbelasting van geen enkele aftrekpost gebruik maken. 
Overigens heeft het Duitse Ministerie van Financiën inmiddels aan de Duitse Bondsdag voorgesteld om het Duits-Nederlandse belastingverdrag als voorbeeld te nemen voor andere door Duitsland af te sluiten bilaterale belastingverdragen. Nederland heeft daarentegen enkele jaren geleden aan Duitsland voorgesteld om, analoog aan het belastingverdrag tussen Nederland en België, de belastingheffing over de inkomsten van grensarbeiders toe te wijzen aan de woonstaat (FEM, 1989). De Bondsrepubliek Duitsland zou daar echter om budgettaire redenen niets voor voelen. De deelstaat Nordrhein-Westfalen heeft zich niet alleen om financiële redenen, maar ook vanwege de uitvoeringsgevolgen - loskoppeling van de heffing van sociale premies en de inkomstenbelasting - tegen het voorstel uitgesproken. Vervolgens heeft Nederland zijn voorstel aangepast, in die zin dat het beginsel van de woonstaatheffing gehandhaafd blijt maar dat de belastingopbrengst over inkomen van de grensarbeider wordt verdeeld tussen Nederland en Duitsland. Daarmee lijkt dit voorstel sterk op de voorgestelde Belasting-Richtlijn van de Europese Commissie. De onderhandelingen met Duitsland over de voorstellen voor het bilaterale belastingverdrag zijn door Duitsland voor onbepaalde tijd vooruit geschoven aangezien men voorrang wenst te geven aan de fiscale integratie van de voormalige DDR in de Bondsrepubliek Duitsland.

\section{Specifieke fiscale problemen tussen Nederland en België}

In het uit 1970 daterende belastingverdrag tussen Nederland en België is overeengekomen dat het heffingsrecht over het arbeidsinkomen van de grensarbeiders in beginsel toekomt aan de woonland. Enkele knelpunten die zich in de jaren daarna manifesteerden werden via ministeriële resoluties opgelost. Dit verdrag wordt vrij unaniem als bevredigend beschouwd. Niettemin blijven er ten aanzien van de uitvoering van het verdrag nog knelpunten bestaan. Zo zijn de (ex-) werknemers verantwoordelijk gesteld voor het twee-jaarlijks aanvragen en verkrijgen van de Beschikking Vrijstelling Loonbelasting ('grensarbeidersverklaring'), zodat de werkgever en uitkerende instanties zoals bedrijfsverenigingen en pensioenfondsen geen loon- of inkomstenbelasting hoeven in te houden. Het blijkt in de praktijk echter veelvuldig voor te komen dat deze verklaring niet tijdig wordt aangevraagd of verstrekt. In dat geval zal er wel inhouding van het werkgeversdeel van de inkomstenbelasting plaatsvinden. Deze zal dan achteraf, indien de pendelaar daar weet van krijgt, teruggevorderd moeten worden bij de Nederlandse belastingdienst. Dit was tot voor kort een omslachtige en langdurige operatie waarbij bovendien renteverlies wordt geleden.

De heer M. is woonachtig in de Belgische Voerstreek en sedert 1977 werkzaam als internationaal chauffeur bij een Nederlandse transportonderneming in Maastricht. Hij heeft indertijd op advies van zijn werkgever een grensarbeiderverklaring ingevuld en deze steeds laten vertengen. Hil werd hierdoor, volgens het BelgischNederlandse beslatingverdrag viijgesteld van belastingheffing in Nederland ten gunste van België. Nu zijn de werkgever en de Nederlandse belastingdienst echter tot de ontdekking gekomen dat het verdrag niet op M. van toepassing is, aangezien hij als internationaal chauffeur het grootste deel van zijn werktijd niet in de grensstreek werkzaam is. De Nedertandse belastingdienst beraadt zich nu of tot heffing met terugwerkende kracht moet worden overgegaan.

In januari 1991 heeft er in Nederland een centralisatie plaats gevonden van alle 'buitenlandse' belastingzaken bij de Belastingdienst in Brunssum. Er is nu echter een nogal gecompliceerde vragenlijst opgesteld, voor terugvorderingen op grond van verdragen en nationale sociale wetgeving, die geldt voor de grensarbeiders waarop de grensarbeidersverklaring (model 90-A) van toepassing is. 
Bovengenoemde terugvorderingsproblematiek doet zich nog veel vaker voor bij de uitkeringen door bedrijfsverenigingen, pensioenfondsen, VUT-fondsen, e.d. Ook hier vindt er invordering van loonbelasting plaats in het voormalige werkland. Dit zou echter voorkomen kunnen worden indien het uitkeringsorgaan de beschikking heeft over een 'Beschikking Vrijstelling Loonbelasting', dat wil zeggen een toestemming van de belastinginspecteur om de loonbelasting niet in te houden, maar uit te keren aan de pendelaar, zodat deze vervolgens aan de Belgische belastingdienst belasting kan afdragen.

\section{Specifieke fiscale problemen tussen België en Duitsland}

Ook tussen Duitsland en België bestaat een belastingverdrag. Hierin is het woonland gerechtigd tot belastingheffing, echter alleen voorzover het grenspendelaars betreft. Deze dienen volgens het verdrag binnen een gebied van $20 \mathrm{~km}$. van de grens woonachtig én werkzaam te zijn. Overigens geldt voor Belgen die werkzaam zijn in Duitse overheidsdienst, dat men in Duitsland inkomstenbelasting dient af te dragen. Volgens een nota van het Duitse Ministerie van Financiën (Finanz Min., 1990) hebben zowel de Duitse als de Belgische pendelaars overigens een voorkeur voor belastingheffing in Duitsland aangezien die lager is. België heeft voorgesteld om een eventuele overgang naar belastingheffing in het werkland in een breed opgezet belastingakkoord te regelen.

\section{Knelpunten in het betalingsverkeer: wisselkoersen en banktransacties}

Indien salarissen, pensioenen e.d. op een rekening in het (voormalige) werkland gestort worden, moeten pendelaars dit in contanten opnemen om het vervolgens over de grens te brengen en in eigen land weer te kunnen omwisselen tegen een doorgaans ongunstige wisselkoers. Mogelijke problemen doen zich, naast een riskant deviezentransport, in dit verband vooral voor bij schommelingen in wisselkoersen en vanwege de door banken gehanteerde relatief hoge tarieven voor grensoverschrijdend betalingsverkeer. Deze hoge tarieven zijn het gevolg van het feit dat internationale girale overboekingen nog steeds handmatig worden uitgevoerd. Voor de bestedingsmogelijkheden van de salarisrekening in het werkland zijn de ontwikkelingen op het gebied van betaalkaarten en betaalautomaten van belang. Deze zullen op den duur het Eurocheque- en de daarmee vergelijkbare stelsels gaan vervangen.

Een in de Belgische grensstreek woonachtige Nederlander met een Nederlandse Postgirorekening diende op korte termijn een verzekeringspremie te voldoen en maakte daarvoor een (klein) geldbedrag over naar een Nederlandse Bank. Deze bracht daarvoor $f 15,-$ in mindering op het overgemaakte bedrag, hoewel er geen vreemde valutatransactie had plaats gevonden. Hierdoor was de premie nog niet voldaan op het moment dat de verzekering diende in te gaan.

\subsubsection{Sociale zekerheid en pensioenen}

De sociale verzekeringspositie van pendelaars wordt voor een belangrijk deel geregeld in EGVerordening $\mathrm{nr}$. 1408/71. Volgens deze Verordening is een grensarbeider slechts aan de wetgeving van één enkele lidstaat onderworpen. In beginsel is de grensarbeider voor wat betreft de verplichting van verzekering en premiebetaling onderworpen aan de wettelijke voorschriften van het land waar hij of zij werkt. De problemen waarmee de grensarbeiders desalniettemin te kampen hebben, vloeien voort uit de verschillende uitgangspunten van de nationale stelsels van sociale zekerheid. Ook leiden interpretatieverschillen van de bestaande bilaterale verdragen tot problemen. 
Verschillende deskundigen, waarmee in het kader van het onderzoek is gesproken, zijn van mening dat een harmonisatie van de nationale stelsels van sociale zekerheid in de komende decennia niet is te verwachten. Daarvoor lopen de welvaartsverschillen tussen bijvoorbeeld Portugal en Nederland teveel uiteen. Er wordt veeleer gestreefd naar een coördinatie van regelgeving en wetgeving en er worden, waar mogelijk, initiatieven ontwikkeld om te komen tot convergentie, dat wil zeggen het op termijn zoveel mogelijk naar elkaar doen toegroeien van de stelsels. Wel moet men bedenken dat dit uiteindelijk op het terrein ligt van de soevereine lidstaten. Het Gemeenschapshandvest van sociale grondrechten geeft de Europese Commissie de bevoegdheid om coördinerende richtlijnen te ontwikkelen om de ongewenste gevolgen van grensoverschrijdende toepassing van de sociale zekerheidsstelsels weg te nemen.

Op nationaal niveau kunnen convergentie en coördinatie tot stand worden gebracht op basis van bilaterale verdragen en door middel van wijzigingen in de nationale wetgeving. De snelste niettemin evenzeer moeizame weg, om tot coördinatie te komen ligt echter in het ontwikkelen van jurisprudentie door middel van tot op Europees niveau uitgevochten procedures. De hieruit voortkomende uitspraken gelden immers voor alle EG-landen en staan boven de nationale wetgeving.

Binnen het thema van de sociale zekerheid wordt een aparte positie ingenomen door de aanvullende pensioenen (ABP, 1991). Het is in vrijwel de gehele Europese Gemeenschap gebruikelijk dat er in de opbouw van pensioenen sprake is van een driedeling:

- een basislaag, geregeld via sociale verzekeringen;

- een aanvullende laag, per bedrijf of bedrijfstak opgezet;

- een toplaag, individueel in te vullen, meestal bij een verzekeringsmaatschappij.

in Duitsland en België is de basislaag veel belangrijker voor het inkomen van de gepensioneerden, dan in Nederland, waar de aanvullende laag erg belangrijk is. Om op het terrein van de aanvullende pensioenen binnen de EG een assimilatie te bereiken is eerst het naar elkaar toegroeien van de basisregelingen noodzakelijk. Het zal echter nog geruime tijd duren voordat dit tot stand zal zijn gebracht.

Ook ten aanzien van de ziektekostenverzekering worden grensarbeiders met problemen geconfronteerd. In de regel wordt een grensarbeider medisch behandeld in het land waarin deze woont. Dit geldt ook voor gezinsleden van de pendelaar. Pendelaars kunnen zich daarnaast ook laten behandelen in het werkland. Voor de gezinsleden van de grensarbeiders is dit echter alleen mogelijk indien er sprake is van een spoedgeval of een verdrag tot samenwerking tussen de bevoegde instanties. De Europese Commissie overweegt om deze beperkende voorwaarden af te schaffen, zodat de gezinnen van grensarbeiders de vrije keuze wordt gelaten. 'Dit zou niet alleen een verlichting zijn voor de betrokken personen maar zou ook een aansporing vormen tot het optimaal gebruik van de aan weerszijden van een grens bestaande medische voorzieningen'. Dit knelpunt is inmiddels ook onderkend door de Provinciale Raad voor de Volksgezondheid in Limburg. In de recente nota Volksgezondheidsverkenningen wordt uitvoerig aandacht geschonken aan de medische voorzieningen in de Limburgse grensstreken (PRVL, 1991).

Gepensioneerde pendelaars en hun gezinsleden komen echter doorgaans niet meer in aanmerking voor medische voorzieningen in het voormalige werkland. Men is aangewezen op de medische voorzieningen in het woonland. De in rekening gebrachte kosten kunnen dan veel hoger liggen, omdat men pas na pensionering is toegetreden. Het zou wenselijk zijn dat wordt onderzocht in hoeverre de gepensioneerden zich verder kunnen laten behandelen in het land waarin zij vroeger hebben gewerkt. 
Eén van de wijzen waarop niet alleen misbruik wordt gemaakt van de verschilen in de nationate stelsels van sociale zekerheidswetgeving, maar ook van de onwetendheid van (potentiäle) grenspendelaars, zijn de internationale koppelbaaspraktijken in de bouw. Deze spelen zowel in de Nederlands-Duitse als Nederlands-Betgische grensstreek.

Nederlandse bouwvakkers worden in dienst genomen bi een aannemersbedrif in Sittard. Dit bouwbedrif verricht alkeen werkzaamheden in Dultsland. De Nederlandse werknemers verkiligen derhalve geen detacheringsverklaring van het Bureau voor Duitse Zaken, zodat de werknemers in Duitsland verzekerd moeten zin. In de door de werknemers ondertekende arbeidsovereenkomst worden de in de CAO overeengekomen regels nietig verklaard ten gunste van de in het bedrif geldende regels. De werknemers ontvangen aan het eind van ledere werkdag een contant geldbedrag in Duitse marken. Verzekering in het buitenland heeft echter naar alle waarschijnilikheid dan niet plaatsgevonden (het onderzoek hiernaar is nog aan de gang).

Een Belgisch bouwbedrif heeft hoofdzakelijk Nedertanders in dienst die, via een aantal tussenbedrijen, worden uitgeleend en te werk worden gesteld op bouwplaatsen in Nederland. Deze werknemers krijgen een Belgische arbeidsovereenkomst, hetgeen illegaal is: men zou een Belgische detacheringsverklaring of een Nederlandse arbeidsovereenkomst moeten krijgen. Volgens deze arbeidsovereenkomst zijn de sociale lasten afgedragen in Belgiẻ. De werknemers krijgen het loon contant uitbetaald. Zij bliken echter, bij navraag, onverzekerd te zijn en bijvoorbeeld ook geen vakantiegeld te ontvangen. Na onderzoek van de Belgische justitie blijkt het bedriff uit niet meer dan een brievenbus te bestaan.

In het vervolg van deze paragraaf zal achtereenvolgens nader worden ingegaan op enkele specifieke belemmeringen tussen Duitsland en Nederland, tussen België en Nederland en tussen België en Duitsland.

\section{Specifieke knelpunten tussen Duitsland en Nederland}

Op initiatief van de Euregio Twente-Westmünsterland is medio 1989 een brede werkgroep 'pendelaars' samengesteld, die een uitvoerige inventarisatie heeft gemaakt van de knelpunten rondom de Nederlandse en Duitse wetgeving op het gebied van belastingen en sociale zekerheid. De belangrijkste knelpunten worden hieronder besproken.

\section{Ziekte(kosten)verzekering}

De gezinsleden van een Nederlandse grensarbeider kunnen, ofschoon ze in Duitsland verzekerd zijn, in principe geen gebruik maken van Duitse voorzieningen. Wordt de echtgenote van een in Duitsland verzekerde Nederlandse grensarbeider 65 jaar, dan zal zij zich in Nederland particulier moeten verzekeren. Wanneer een Nederlandse grensarbeider 65 jaar wordt en daardoor in Duitsland wordt uitgesloten van de Krankenversicherung der Rentner, dan zal hij of zij zich in Nederland particulier moeten verzekeren. Men komt evenmin in aanmerking voor een "Zuschuss" van de Duitse Rentenversicherungsanstalt. De Nederlandse grensarbeider heeft in Nederland geen recht op voorzieningen volgens de AAW. Ontvangt een arbeidsongeschikte Nederlandse grensarbeider een Duitse Arbeitsunfähigkeitsrente die meer bedraagt dan zijn WAO-uitkering, dan hebben de gezinsleden geen recht op medeverzekering bij het Nederlandse ziekenfonds. Ontvangt de weduwe van een overleden Nederlandse grensarbeider een Duitse weduwenuitkering die meer bedraagt dan haar AWW-uitkering, dan hebben haar kinderen geen recht op medeverzekering bij het Nederlandse ziekenfonds.

\section{Arbeidsongeschiktheidsverzekering}

De Nederlandse grensarbeider die in Nederland na 52 weken ziekte arbeidsongeschikt zou worden verklaard, kan nog geen aanspraak maken op een arbeidsongeschiktheidsuitkering, omdat er volgens Duitse normen nog geen sprake is van arbeidsongeschiktheid. Wordt een Nederlandse grensarbeider na 78 weken ziekte door Duitsland arbeidsongeschikt verklaard, maar was deze ziekteperiode de laatste 52 weken niet aaneengesloten, dan kan hij of zij geen 
aanspraak maken op een WAO-uitkering, omdat er volgens Nederlandse normen nog geen sprake is van arbeidsongeschiktheid. Vanaf het moment dat Nederlandse grensarbeiders op grond van een (pro-rata) WAO-uitkering weer verzekerd zijn volgens de AAW, geldt een wachttijd van 6 jaar alvorens men aanspraak kan maken op AAW-voorzieningen.

\section{Ouderdomsvoorzieningen en pensioenen}

Wanneer Nederlandse grensarbeiders vervroegd met pensioen gaan, moet over het gedeeltelijke ouderdomspensioen dat men uit Duitsland ontvangt, premie volksverzekering worden betaald. Als gevolg daarvan loopt men het risico onder het bijstandsniveau te geraken. De echtgenote van de Nederlandse grensarbeider komt niet in aanmerking voor kinderopvoedingstijdvakken ("Kindererziehungszeiten"), ondanks de binding van haar echtgenoot met de Rentenversicherung. Wanneer de echtgenote van een Nederlandse grensarbeider gaat scheiden van haar man, krijgt zij bij het bereiken van de 65-jarige leeftijd in principe niets van het door haar man in Duitsland opgebouwde pensioen. Nederlandse vrouwen die in Duitsland een part-time dienstbetrekking hebben vervuld, zullen bij het bereiken van de 65-jarige leeftijd hun pensioen veelal moeten aanvullen met een bijstandsuitkering.

\section{Kinderbijslag}

De partner van de Nederlandse grensarbeider komt niet in aanmerking voor "Kindererziehungsgeld". De grensarbeider zal zijn dienstbetrekking moeten onderbreken of beëindigen om aanspraak te kunnen maken op deze uitkering. Nederlandse grensarbeiders zonder partner ontvangen geen Nederlandse kinderbijslag en zijn aangewezen op de lage Duitse kinderbijslag.

\section{Weduwen- en wezenuitkering}

De weduwe van een Nederlandse grensarbeider wordt bij het bereiken van de 65 -jarige leeftijd gekort op haar Duitse weduwenpensioen, indien haar AOW omgerekend (in 1989) meer bedraagt dan DM 984,- .

De heer $X$ is woonachtig in Urmond (Nederland) en werkzaam in Duitsland. Hij heeft hiervoor een detacheringsbewijs van het Bureau voor Duitse Zaken in Nilimegen verkregen en verkeert derhalve in de terechte veronderstelling ook in Duitsland verzekerd te $z i j n$. In 1985 viel $X$ in Keulen uit een hoogspanningsmast. Hij werd met een helikopter (uit medische noodzaak) vervoerd naar een ziekenhuis in Duisburg. De rekening van de helikopter werd naar de betrokkene thuis gestuurd. De echtgenote van $X$ ging hiermee naar het Centraal Ziekenfonds (CZF) te Sittard. Deze weigerde de rekening te betalen omdat de verleende huip niet tot het ziekenfondspakket behoort en stuurde de rekening terug naar de Bundesgenossenschaft. De Bundesgenossenschaft stuurde de rekening echter weer terug naar $\mathrm{X}$, omdat de rekening volgens de Bundesgenossenschaft wel door CZF diende te worden voldaan. Dit gebeurde tot drie keer toe, waarbij de rekening werd verhoogd met honderden D-marken als gevolg van boete-aanmaningen. Het is ons niet bekend of en door wie de rekening uiteindelijk is betaald. De echtgenote van $X$ moest geruime tijd 300 $\mathrm{km}$ per dag rijden om de zeer zwaar gewonde $X$ te kunnen bezoeken. Er werd haar niet verteld dat zil gedurende die kritieke periode in Duisburg had kunnen logeren, omdat men niet wist wie de verblifkosten zou betalen. De reiskosten gemaakt door de echtgenote, zouden echter worden vergoed door de Bundesgenossenschaft. Toen hiervoor een vergoeding werd aangevraagd werd echter naar het CZF verwezen. Deze achtte zich echter op haar beurt eveneens niet aansprakelijk, omdat de Nederlandse wetgeving alleen spreekt over verpleging in een in Nederland gelegen ziekenhuis. De heer $X$ kwam ruim twee maanden na het ongeval naar huis om even op rust te komen en kreeg toen van het CZF bericht dat hij niet meer in Duitsland behandeld mocht worden. Dit ondanks reeds gemaakte afspraken voor verdere consulten en behandelingen en ook ondanks het feit dat de huisarts en andere artsen de voorkeur gaven aan verdere behandeling in Duisburg. De betrokkene is toen in het ziekenhuis van Sittard verder behandeld. 


\section{Specifieke knelpunten tussen België en Nederland}

Overeenkomstig de hoofdrichting van de pendel tussen België en Nederland zijn de knelpunten vooral van Belgische zijde in kaart gebracht. Het Belgische Algemeen Christelijk Vakverbond (ACV) heeft reeds 20 jaar een Dienst Grensarbeiders, welke op vijf plaatsen langs de Belgische grens kantoor houdt. Het aantal jaarlijks in behandeling genomen individuele dossiers op het terrein van met name de sociale zekerheid en de pensioenwetgeving is in de periode van 1983 tot 1990 gestegen van 256 tot 421 . Enkele problemen die zich momenteel nog voordoen worden hieronder besproken.

\section{Ziekte(kosten)verzekering}

De Belgische grensarbeider (met een inkomen tot $f 52.300,-$ (in 1991)) moet aangesloten blijven bij een Belgisch ziekenfonds, maar tevens moet de Nederlandse werkgever de werknemer aanmelden bij een Nederlands Ziekenfonds. De Belgische grensarbeider is derhalve ook verplicht de nominale premie aan het Nederlandse Ziekenfonds te betalen voor zichzelf en de eventueel mee te verzekeren gezinsleden, als deze geen inkomen in België hebben. Bovendien is de Nederlandse premie hoger dan de Belgische, terwijl de meeverzekerde gezinsleden alleen gebruik kunnen maken van Belgische voorzieningen. De Belgische grensarbeider met een inkomen boven $f 52.300$, - dient een particuliere ziektekostenverzekering af te sluiten. Deze premie is echter in België fiscaal niet aftrekbaar. Bovendien zijn AWBZ-verstrekkingen niet 'exporteerbaar'. Ook is het problematisch op welke wijze de in het andere land gemaakte medische kosten terugbetaald moeten worden.

\section{Arbeidsongeschiktheidsverzekering}

Er bestaat onduidelijkheid over de gevolgen indien men in beide landen werkzaam is geweest en geheel of gedeeltelijk arbeidsongeschikt wordt.

\section{Werkloosheidsverzekering}

Hierbij treden er problemen op bij deeltijdpendel.

\section{Ouderdomsvoorzieningen en pensioenen}

Grensarbeiders dienen binnen een jaar na tewerkstelling hun partner aan te melden bij de Sociale Verzekeringsbank te Amsterdam omwille van de medeverzekering en de eigen opbouw van het AOW-pensioen. De partner zal dan wel zelf de vrijwillige AOW-premie moeten betalen. Deze is in België niet fiscaal aftrekbaar. Daar staat tegenover dat het latere recht op het AOWpensioengedeelte ten bate van die partner in België ook niet belastbaar is. Indien de partner op 65 -jarige leeftijd een eigen pensioenuitkering toegekend krijgt, op basis van eigen opgebouwde verzekeringstijdvakken, dan is dat deel echter wel belastbaar in België.

Belgische grensarbeiders worden geconfronteerd met een herberekening van het reeds toegekende Belgische rustpensioen. Deze herziening heeft ten gevolge dat het Belgische gezinspensioen wordt herleid tot het rustpensioen van een alleenstaande (omdat de partner een eigen AOW-uitkering geniet uit Nederland) sinds de AOW-wijziging in Nederland. Dit kan tot grote financiële nadelen leiden voor gepensioneerde ex-pendelaars.

\section{Kinderbijslag}

Indien één van de ouders in België werkt en de andere naar Nederland pendelt, hebben zij naast het recht op kindergeld uit België, ook recht op een aanvulling van Nederlandse zijde (bijvoorbeeld uitwonende en/of studerende kinderen). Voor zeer veel grensarbeiders is deze regeling echter onbekend, aangezien er vrijwel geen enkele instantie is die ze daarop opmerkzaam maakt. 
Een Belgisch gezin uit Kinrool had recht op Belgische kinderbijslag (via de vader) en een Nederlandse aanvulling, omdat de moeder in Nederland werkzaam was. Zij werden hierop gewezen tidens een voorlichtingsavond van de ACV. Herberekening leidde tot een toekenning van een achterstallige Nederlandse kinderbijstag van circa $f 13.000,-$

\section{Specifieke knelpunten tussen België en Duitsland}

Een grote groep Belgen is in Duitsland werkzaam op basis van een seizoenscontract. Daarin staat doorgaans een bepaling dat men in Duitsland geen aanspraak kan maken op een uitkering in geval van ziekte. Omdat er echter in de tijd dat men in Duitsland werkzaam is geen premie wordt afgedragen in België, kan men ook daar niet voor een ziekte-uitkering in aanmerking komen, zodat deze groep van pendelaars wat dit betreft in feite onverzekerd is.

Indien een Belgische pendelaar met een arbeidsverleden in zowel Duitsland als België, op het moment dat deze in Duitsland werkzaam is, geheel of gedeeltelijk arbeidsongeschikt wordt, dan ligt de hoogte van de uitkering op het minimumniveau. De reden daarvoor ligt in het feit dat de uitgangspunten voor de verzekeringsstelsels in beide landen uiteenlopen. In Duitsland geldt het opbouwsysteem: hoe langer men werkt des te meer rechten men opbouwt. In België geldt echter het risicosysteem, waarbij de berekening van de uitkering plaatsvindt op basis van het laatstverdiende loon.

Ook op het terrein van de Kinderbijslag doen zich bij pendelarbeid tussen België en Duitsland soortgelijke problemen voor als bij pendelarbeid tussen België en Nederland. 


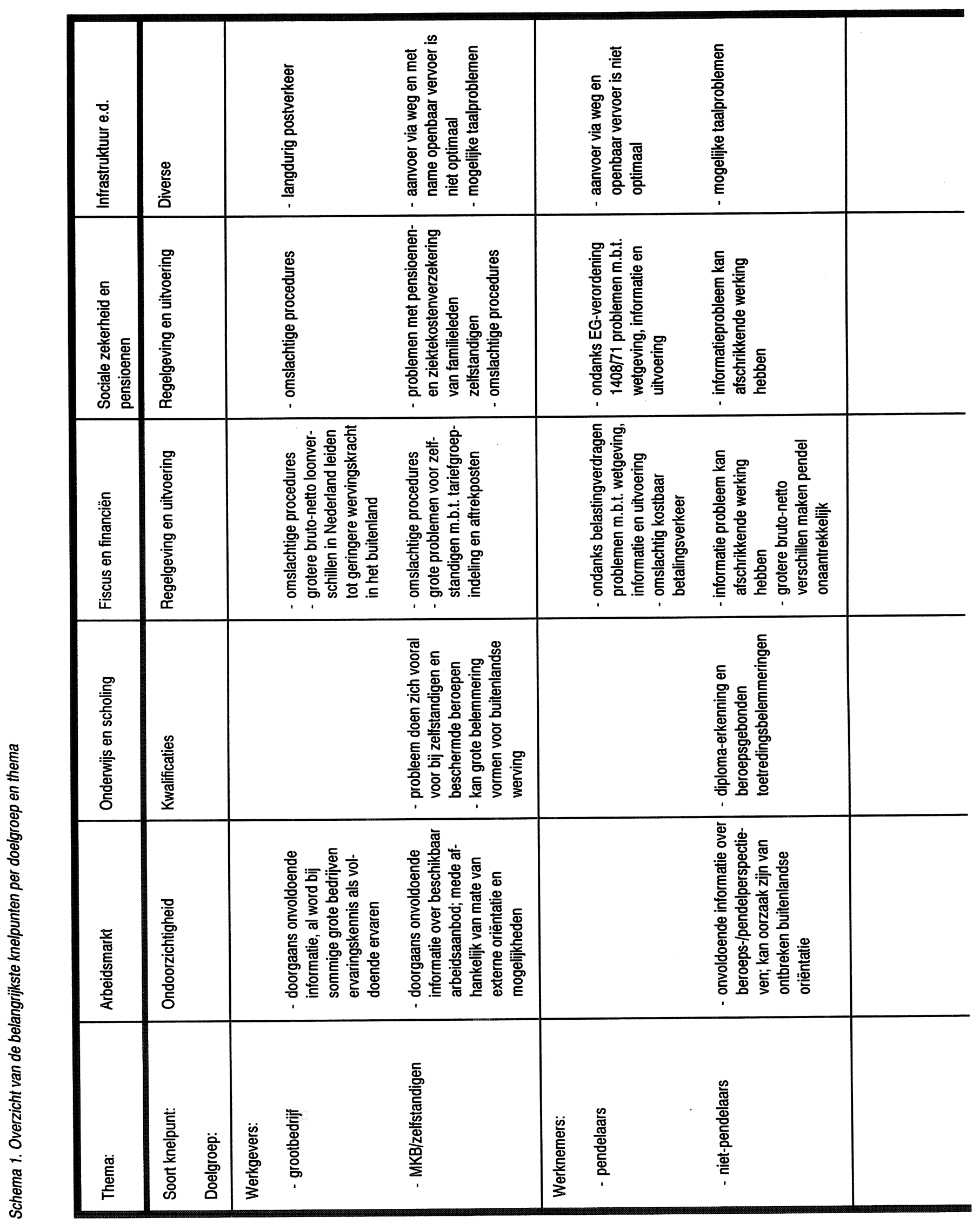




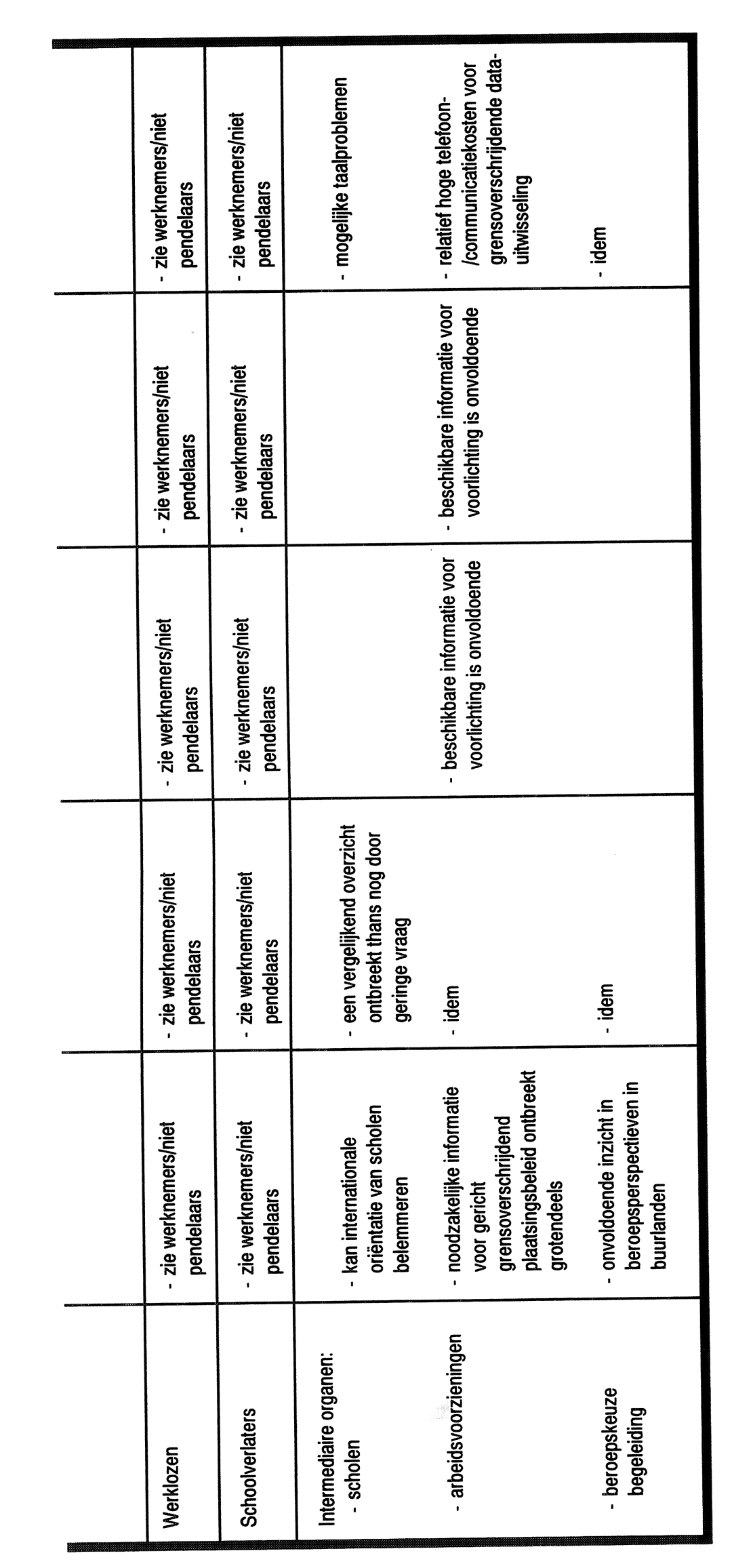




\section{HUIDIGE ACTIVITEITEN EN INITIATIEVEN}

\subsection{INLEIDING}

In dit hoofdstuk wordt een overzicht gepresenteerd van een groot aantal activiteiten en beleidsinitiatieven die tot op heden zijn ondernomen, om belemmeringen rondom grensoverschrijdende arbeid en scholing weg te nemen. Daarbij wordt telkens een onderscheid gemaakt tussen een drietal beleidsniveaus: het communautair niveau, het nationaal of bilateraal niveau en het Euregionale niveau (zie paragraaf 4.2.). Het accent ligt daarbij op het in kaart brengen van de belangrijkste beleidsinitiatieven op Euregionaal niveau. Op communautair en nationaal/bilateraal niveau is de hier gegeven opsomming derhalve ongetwijfeld verre van volledig. De hier genoemde beleidsinitiatieven op deze beide laatstgenoemde niveaus hebben dan ook slechts de pretentie een indicatie te geven van de context waarbinnen de Euregionale beleidsvorming dient plaats te vinden. Ten aanzien van de initiatieven op nationaal/bilateraal niveau is bovendien met name gekeken naar Nederlandse projecten (al dan niet in samenwerking met België of Duitsland). In paragraaf 4.3. worden enkele Euregionale initiatieven op het terrein van de voorlichting en enkele Euregionale scholingsprojecten meer uitgebreid beschreven. In paragraaf 4.4. wordt tenslotte een schematisch overzicht gegeven van de belangrijkste in dit hoofdstuk genoemde activiteiten op met name het Euregionale niveau.

\subsection{OVERZICHT VAN INITIATIEVEN PER THEMA}

\subsubsection{Arbeidsmarkt}

Binnen het themagebied arbeidsmarkt is er reeds sprake van een groot aantal activiteiten en beleidsinitiatieven.

Op communautair niveau:

- door het statistische bureau van de Europese Gemeenschap "Eurostat" worden vergelijkbare arbeidsmarktgegevens verzameld op basis van de in de lidstaten gehouden "Labour Force Surveys". Vooralsnog hebben deze arbeidsmarktdata betrekking op een relatief hoog aggregatieniveau naar beroep, opleiding en regio;

- teneinde grensoverschrijdende vacatureuitwisseling en arbeidsbemiddeling mogelijk te maken wordt met ondersteuning van de Europese Commissie gewerkt aan de ontwikkeling van Job Euro Transfer (JET) als opvolger van het SEDOC-systeem. JET is een speciaal op de grensgebieden gericht instrument, dat de uitwisseling van gegevens over vraag en aanbod van werk tussen de openbare arbeidsbureaus in de grensgebieden mogelijk moet maken. Tussen Tilburg en Turnhout heeft JET enige tijd proef gedraaid. Men kwam daar tot de conclusie dat het systeem niet alleen erg bewerkelijk is, maar bovendien dat er, na lang zoeken, in beide grensregio's vaak sprake blijkt te zijn van dezelfde (moeilijk vervulbare) vacatures. Hetzelfde lot lijkt andere vacature-uitwisselingssystemen beschoren te zijn, zolang niet voorzien kan worden in een essentiële tekortkoming: het ontbreken van een voldoende gedetailleerd, grensoverschrijdend, kwantitatief inzicht in de vraag- aanbod verhoudingen naar bedrijfstak en beroepsgroep. Om de samenwerking tussen de arbeidsbureaus uit de grensgebieden te bevorderen worden door de Europese Commissie seminars georganiseerd. De Commissie heeft overigens het voornemen om communautaire regelgeving te ontwikkelen voor de activiteiten van grensoverschrijdende arbeidsbemiddeling van uitzendbureaus;

- met behulp van diverse EG-programma's wordt getracht de samenwerking tussen overheden, vakbonden, werkgevers en beroepsorganisaties op intraregionaal en internationaal niveau, te bevorderen; 
- onder auspiciën van de Europese Commissie verschijnen vier maal per jaar de bulletins 'Sysdem' en 'MISEP', met informatie over aspecten van respectievelijk de arbeidsmarkt en het gevoerde werkgelegenheidsbeleid in de afzonderlijke lidstaten.

Op nationaal/bilateraal niveau:

- het Nederlandse Ministerie van Economische Zaken heeft zich in de recente nota 'Regio's zonder grenzen' uitgesproken voor ondersteuning van grensoverschrijdende initiatieven;

- het Nederlandse Centraal Bestuur voor de Arbeidsvoorziening (CBA) heeft een onderzoek laten verrichten naar de omvang van de internationale arbeidsbemiddeling. In de praktijk blijkt de internationale arbeidsbemiddeling zich te beperken tot de uitwisseling van enkele bemiddelaars. Van een Europese arbeidsbemiddeling is volstrekt geen sprake (CBA, 1991).

- Enkele internationaal opererende job-management bureaus verrichten internationaal vergelijkende salarisonderzoeken en wervings- en bemiddelingsactiviteiten voor hogere managementfuncties.

Op Euregionaal niveau:

- ieder kwartaal wordt een Euregionale banenbeurs georganiseerd;

- in de Euregio Maas-Rijn wordt een elektronisch systeem ontwikkeld gericht op de informatieuitwisseling tussen de arbeidsbureaus in de Euregio met betrekking tot de geregistreerde vacatures en ter vermijding van de nadelen van JET;

- in het kader van het project Euroloket/Intensieve Grensoverschrijdende Activiteiten (IGA) worden er initiatieven genomen op het vlak van bemiddeling, beroepsopleiding en informatievoorziening langs de gehele Nederlandse grensstreek. Het Euroloketproject is een pilot-project gericht op verbetering van de vacature-uitwisseling, het opzetten van een databank Sociale Zekerheid, de vergelijking van Belgische en Nederlandse beroepsopleidingen en het verbeteren van het inzicht in de opleidingsmogelijkheden;

- op het terrein van de grensoverschrijdende arbeidsbemiddeling zijn de uitzendbureaus het meest actief;

- informatie-verschaffing aan potentiële Belgische en Nederlandse grensarbeiders door ontwikkeling en verspreiding van folders door RBA Zuid-Limburg en VDAB Tongeren.

\subsubsection{Onderwijs en scholing}

Ten aanzien van het themagebied onderwijs en scholing zijn de volgende activiteiten en beleidsinitiatieven van belang.

Op communautair niveau:

- vanuit diverse Europese programma's worden er projecten gefinancierd op het terrein van onderwijs en scholing. Naast activiteiten die plaatsvinden in het kader van de INTERREG, FORCE- en TRANSITION programma's, bestaan er op communautair niveau ook specifieke programma's ten aanzien van de:

- mobiliteitsbevordering van studenten: ERASMUS;

- samenwerking tussen universiteiten en ondernemingen met betrekking tot nieuwe technologie: COMETT;

- bevordering van vreemde-talenonderwijs: LINGUA;

- uitwisseling van jonge werknemers: 'Jeugd voor Europa';

- samenwerking en verspreiding van informatie over onderwijszaken: EURYDICE en ARION;

- voorbereiding van jongeren op werk en volwassenheid: PETRA;

- ontwikkeling van beroepsopleidingen op het gebied van nieuwe technologie: EUROTECNET;

- gelijke kansen voor vrouwen, door onder meer de beroepsopleiding: IRIS;

- ontwikkeling van de beroepsopleiding door informatie, onderzoek en overleg: CEDEFOP; 
- op initiatief van EUDAT wordt eind november 1991 in Maastricht een conferentie georganiseerd met betrekking tot "The role of Information Systems for Education and Training";

- de Europese Commissie ondersteunt de ontwikkeling van een handleiding voor de beroepskeuzevoorlichtingscentra in de Lidstaten;

- voor het hoger onderwijs van drie jaar of langer is er reeds een regeling ten aanzien van de diplomaregeling tot standgekomen (zie ook hoofdstuk 3). De regelgeving voor beroepsopleidingen van minder dan drie jaar en voor getuigschriften van vakbekwaamheid is nog in voorbereiding. Deze richtlijn zal gaan gelden voor alle zogeheten "gereglementeerde beroepen". Daaronder worden zowel alle bij wet geregelde beroepen als de door CAO geregelde beroepen of overheidsdiensten bedoeld (Tweede Kamer, 1991).

\section{Op nationaal/bilateraal niveau:}

- door de Vlaamse en Nederlandse Minister van Onderwijs is in 1990 een samenwerkingsakkoord voor onderwijs (GENT) afgesloten;

- verschillende beroepsorganisaties en opleidingsstelsels uit het leerlingwezen zijn betrokken bij grensoverschrijdende scholingsprojecten.

\section{Op Euregionaal niveau:}

- in de Euregio Maas-Rijn is momenteel sprake van een beperkt aantal grensoverschrijdende scholingsprojecten. Deze zijn voornamelijk op initiatief van opleidingsinstanties en brancheorganisaties tot stand gekomen. Opvallend is dat verreweg de meeste projecten zich voor doen in de Nederlands-Duitse grensstreek. De projecten in het algemeen voortgezet onderwijs lijken zich vooralsnog meer te richten op kennismaking en uitwisseling. Bij het beroepsonderwijs lijkt er daarentegen vaker sprake te zijn van gezamenlijke scholingsprojecten, met betrekking tot onder meer de gezondheidszorg, het economisch- en administratief onderwijs, de procestechnologie en computersimulatie, metaalbewerking en het internationale transport.

- in 1987 is in de Euregio Twente-Westmünsterland de Stichting GrensOverschrijdende Beroepsopleiding (SGOB) opgericht, met als doel het ontwikkelen, opstarten, begeleiden en in stand houden van grensoverschrijdende opleidingen en cursussen. Door samenwerking en afstemming op het gebied van opleidingen, scholing en examinering dient er langzamerhand een gelijkschakeling van opleidingskwalificaties van vaklieden te ontstaan waardoor de mobiliteit van werknemers toe kan nemen.

- de universiteiten in de Euregio Maas-Rijn hebben enige tijd geleden op bestuurlijk niveau een samenwerkingsakkoord gesloten. Vanaf september 1992 zal de eerste 'transnationale' studierichting kennistechnologie gevolgd kunnen worden aan de universiteiten van Hasselt/Diepenbeek en Maastricht. Problemen waarvoor binnen het GENT-akkoord nog naar oplossingen wordt gezocht hebben betrekking op de bekostiging, de studiefinanciering en de erkenning van de te verkrijgen titel (doctorandus).

\subsubsection{Fiscus en financiën}

Binnen het themagebied fiscus en financiën zijn de volgende activiteiten en beleidsinitiatieven vermeldenswaard.

Op communautair niveau:

- de Europese Commissie tracht reeds vanaf 1979 om een bevredigende richtlijn op het terrein van de direkte individuele belastingheffing te ontwerpen. Het voorstel hiervoor wordt echter nog steeds op het niveau van de Raad van Ministers geblokkeerd. De Europese Commissie laat een onderzoek verrichten naar alternatieven voor de oorspronkelijk voorgestelde richtlijn. Tegelijkertijd is de Commissie van plan om maatregelen (in de vorm van inbreukprocedures) te nemen tegen verschillende vormen van discriminatie waaraan de grensarbeiders op grond van nationale belastingregelingen zijn blootgesteld; 
- de Europese Commissie heeft een tijdelijke adviescommissie ingesteld, die een inventarisatie dient te maken van resterende problemen binnen de $E G$, nadat een bepaald pakket maatregelen voor het bedrijfsleven ingevoerd zal zijn. De rapportage van deze CommissieRuding zal naar verwachting eind 1991 plaatsvinden;

- de Raad van Europa heeft een zogeheten ad-hoc werkgroep 'Grensoverschrijdende Samenwerking' in het leven geroepen die zich op korte termijn (medio oktober 1991) dient te orinteren op met name de fiscale problemen bij grensoverschrijdende arbeid;

- volgens de jurisprudentie van het Hof van Justitie van de Europese Gemeenschap verbieden de regels voor gelijke behandeling niet alleen de op nationaliteit gebaseerde vormen van discriminatie, maar ook alle verborgen vormen daarvan die door de hantering van andere criteria, zoals de plaats van herkomst of de woonplaats, tot hetzelfde resultaat leiden. Dit standpunt kan een belangrijke rol spelen bij de problemen rondom de belastingwetgeving. Ten aanzien van de inkomstenbelasting worden door de VEG momenteel proefprocessen gevoerd ten aanzien van een drietal knelpunten: op het terrein van de belasting van in Nederland wonende zelfstandigen die in Duitsland werkzaam zijn; voor alleenstaande ouders die in Nederland wonen en in Duitsland werken; en ten aanzien van de aftrekbaarheid van (bijzondere) kosten voor gehandicapte kinderen van grensarbeiders.

- Door de Europese Commissie (EC, 1990) is een discussiestuk opgesteld over het verrichten van betalingen op de interne markt. Hierin wordt onder meer melding gemaakt van een inventariserend onderzoek door het Europese Bureau van Consumentenverenigingen (BEUC, 1988). Dit onderzoek heeft mede de basis gevormd voor een Aanbeveling van de Europese Commissie, over de transparantie van bankvoorwaarden voor grensoverschrijdende financiële transacties. Deze Aanbeveling bevat de uitgangspunten over het overleg met de centrale banken en de organisatie van commerciële banken.

Op nationaal/bilateraal niveau:

- Nederland, België en Duitsland hebben onderling een drietal bilaterale belastingverdragen gesloten. Deze verdragen hebben verschillende uitgangspunten: ze zijn ofwel gebaseerd op het beginsel van belastingheffing in het land waar de belastingplichtige werkt, ofwel op belastingheffing in het land waar de belastingplichtige woont;

- mede op verzoek van verenigingen van grenslandbewoners is door het Duitse Ministerie van Financiën een knelpunteninventarisatie opgesteld en openbaar gemaakt. Het Nederlandse Ministerie van Financiën heeft alleen voor intern gebruik een inventarisatie verricht. Beide inventarisaties zijn tijdens bilateraal overleg tussen Duitsland en Nederland over mogelijke verdragswijzigingen aan de orde geweest. Het overleg hierover is echter in de afgelopen jaren in een impasse geraakt;

- In Nederland is de uitvoering van de belastingheffing voor in het buitenland woonachtige belastingplichtigen in Nederland, sinds begin 1991 bij één dienstonderdeel van de belastingdienst ondergebracht. Dit dienstonderdeel verstrekt ook telefonische inlichtingen over grensoverschrijdende fiscale zaken.

- De Nederlandsche Bank onderneemt geen concrete activiteiten gericht op het verbeteren van het internationale betalingsverkeer binnen de Europese Gemeenschap. Men verwacht dat de problemen opgelost zullen worden met de komst van een Europese Monetaire Unie en een Europese munteenheid. Vernieuwingen zullen moeten komen van de commerciële banken. De Vereniging van Nederlandse Banken werkt momenteel aan een raamwerk voor grensoverschrijdende samenwerking.

Op Euregionaal niveau:
- de vakbonden in de Euregio Maas-Rijn zijn hun leden behulpzaam bij het invullen van belastingaanslagen. De Belgische ACV is tevens behulpzaam bij het terugvorderen van ten onrechte ingehouden loonbelasting; 
- in het voorjaar van 1992 zal aan de Rijksuniversiteit Limburg een post-academische opleiding van start gaan over het Europees belastingrecht en de hiervoor relevante onderdelen uit het Nederlandse, Belgische en Duitse belastingrecht. In dat verband zal nagegaan worden welke expertise er bij zuster-faculteiten in de Euregio Maas-Rijn aanwezig is of ontwikkeld zou kunnen worden.

\subsubsection{Sociale zekerheid en pensioenen}

Op het terrein van de sociale zekerheid en pensioenen kunnen de volgende bestaande activiteiten en beleidsinitiatieven worden genoemd.

Op communautair niveau:

- door de Europese Commissie wordt gewerkt aan een Aanbeveling voor de lidstaten over de convergentie van de doelstellingen van sociale zekerheidsstelsels;

- een voorstel voor een Verordening 'Werkloosheid en vervroegde uittreding' welke met name de problemen rondom de VUT zou moeten opheffen wordt reeds vanaf 1980 door de Raad geblokkeerd. De Europese Commissie laat momenteel een onderzoek instellen naar de omvang van het VUT-probleem en naar mogelijke alternatieven voor de voorgestelde verordening;

- tegen lidstaten die Verordening 1408/71 niet op de voorgeschreven wijze toepassen zullen inbreukprocedures worden ingesteld;

- analoog aan hetgeen hierboven ten aanzien van de belastingen is opgemerkt, doen zich via de rechtspraak mogelijkheden voor tot coördinatie en wellicht harmonisatie van de sociale zekerheidswetgeving op basis van het 'gelijkheidsbeginsel'.

Op nationaal/bilateraal niveau:

- een Nederlands forum waar de grensgangersproblematiek aan de orde wordt gesteld is de 'Werkgroep Positie Grensgangers' van de Sociale Verzekeringsbank. Deze werkgroep bestaat uit medewerkers van de Bureaus voor Belgische en Duitse Zaken en van de Sociale Verzekeringsbank;

- vertegenwoordigers van de Bureaus voor Duitse en Belgische Zaken zijn met enige regelmaat betrokken bij overleg met Duitse en Belgische instellingen voor de sociale verzekering over onder meer aanvullende overeenkomsten bij de bilaterale verdragen inzake sociale verzekering;

- de grenscommissie van de Euregionale vakbondsraad heeft in 1983 het zogeheten 'Groenboek' opgesteld, met daarin een omvangrijke inventarisatie van allerlei knelpunten rondom grensarbeid. Dit is ter hand gesteld aan circa 500 Belgische en Nederlandse politici en bestuurders. Vervolgens is echter geen actie meer ondernomen.

\section{Op Euregionaal niveau:}

- een door de Euregio Twente-Westmünsterland ingestelde werkgroep 'pendelaars' heeft een inventarisatie opgesteld van de meest voorkomende knelpunten tussen Nederland en Duitsland op het terrein van de Sociale Zekerheid. Deze Knelpuntennota vormt de basis voor overleg met onder meer het Nederlandse Ministerie van Sociale Zaken en Werkgelegenheid;

- medewerkers van de eerder genoemde Bureaus voor Belgische en Duitse Zaken houden maandelijks spreekuur in het kantoor van de Sociale Verzekeringsbank te Maastricht;

- door vakbondsorganisaties en arbeidsvoorzieningsorganisaties in de Euregio Maas-Rijn zijn plannen gepresenteerd voor één of meerdere voorlichtingscentra, die onder meer gericht zouden moeten zijn op de gevolgen van grenspendel voor de sociale zekerheid;

- Hoewel men mag verwachten dat er bij strijdige regelingen en langs elkaar heen werkende administratieve procedures een behoefte bestaat aan grensoverschrijdende rechtsbijstand, zijn op dit punt in de Euregio Maas-Rijn alleen de juridische diensten van vakbonden actief, met concrete afspraken over grens-overschrijdende juridische bijstand voor vakbondsleden bij conflicten op het terrein van de sociale zekerheid. 


\subsection{BESCHRIUVING VAN ENKELE INITIATIEVEN EN SAMENWERKINGSPROJECTEN}

\subsubsection{Voorlichting met betrekking tot pendelproblematiek}

Verschillende instanties in de Euregio Maas-Rijn houden zich op dit moment bezig met het ontwikkelen van ideeën voor de opzet van een voorlichtingsbureau of -netwerk voor pendelarbeid. Het meest concreet zijn de voornemens van enkele arbeidsvoorzieningsorganisaties in de Nederlands-Belgische grensstreek. Volgens het projectvoorstel 'Intensieve grensoverschrijdende contacten' (IGA, 1991), is er grote behoefte aan één of meer grensbureaus waar grensoverschrijdende informatievoorziening naar werkzoekenden en werkgevers op het gebied van beschikbare vacatures, de sociale zekerheid en dagopleidingsmogelijkheden plaats kan hebben. Vanaf september 1991 zou een drietal pilot-projecten moeten gaan draaien, om de hiervoor benodigde produkten en infrastructuur te ontwikkelen. Op deze wijze wordt de voorlichting rondom de pendelproblematiek geïntegreerd met de informatieverstrekking over de arbeidsmarktperspectieven. Volgens de beoogde projectcoördinator is subsidiëring door de Europese Gemeenschap toegezegd. Inmiddels is een onderzoek gestart naar de organisatie, taakstelling en financiering van dit Euroloket-project.

Ook de interregionale vakbondsraad in de Euregio Maas-Rijn heeft medio april 1991 een resolutie aangenomen waarin wordt gepleit voor een tripartiet bestuurd bureau/secretariaat, van waaruit grensoverschrijdende projecten ontwikkeld dienen te worden. Daarnaast dient er volgens deze resolutie in iedere deelregio van de Euregio in de vakbondsgebouwen een Euregioloket te komen waar 'grens-overschrijdende servicepakketten' worden aangeboden. Daarbij gelden de met steun van de Europese Gemeenschap gerealiseerde Euregioloketten in Zuid-België en Noord-Frankrijk als voorbeeld.

Op basis van particulier initiatief heeft het Europees Informatie- en Adviesbureau thans in een drietal plaatsen in het Duitse grensgebied van Nederlands Limburg een adviesbureau geopend, terwijl voor een tweetal andere vestigingsplaatsen plannen bestaan. Tegen vergoeding van de gemaakte kosten ontvangen (potentiële) pendelaars advies en bijstand op het gebied van onder meer belastingen en sociale zekerheid. Voor grensoverschrijdende procedures wordt gebruik gemaakt van enkele bij het bureau bekende Nederlandse en Duitse advocaten.

De Vereniging van Europese Grenslandbewoners (VEG), rond 1980 door een aantal pendelende grenslandbewoners opgericht onder de toenmalige naam Lohnsteuerinitiative Vaals, is aktief op het terrein van voorlichting en belangenbehartiging van pendelarbeiders. De belangrijkste doelstellingen van de VEG zijn:

- voorlichting en advisering aan de leden;

- juridische bijstand en belangenbehartiging;

- politieke lobby en belangenbehartiging;

De VEG geeft o.a. een tweetalig 'Pendelinfo'-bulletin en een voorlichtingsbrochure ('Wonen in Nederland en werken in Duitsland') uit en heeft op vier avonden in de week een telefonisch spreekuur, waar vooral vragen over belastingen en sociale zekerheid beantwoord worden. De VEG verleent ook rechtsbijstand indien een procedure van belang kan zijn voor een grotere groep van pendelaars. Zo worden er op het gebied van belastingwetgeving en sociale zekerheid met enige regelmaat zijn enkele proefprocessen gevoerd. Daarnaast participeert men in enkele werkgroepen van Euregio's. De VEG is van mening dat veel problemen niet alleen het gevolg zijn van de wetgeving, maar ontstaan als gevolg van het feit dat de diverse betrokken instanties dikwijls langs elkaar heenwerken, zodat dezelfde gegevens dikwijls op verschillende plaatsen vastgelegd en geverifieerd worden, waardoor de uitvoering onnodig wordt vertraagd. 
De Bureaus voor Belgische en Duitse Zaken (BBZ en BDZ) houden maandelijks een dag zitting bij de Sociale Verzekeringsbank (SVB) Maastricht. Vooraankondiging daarvan vindt plaats via advertenties in de lokale media. Men kan hier terecht voor voorlichting en adviezen over diverse grensoverschrijdende zaken, die met name betrekking hebben op de sociale verzekeringswetgeving en -uitvoering voor loontrekkenden in respectievelijk België en Duitsland. Het schriftelijke voorlichtingsmateriaal dat daarvoor bij BBZ aanwezig is, beperkt zich tot een erg beknopte weergave van de relevante nationale regelingen. Een nadeel van het spreekuur is de geringe toegankelijkheid als gevolg van het beperkte aantal zittingsdagen (11 per jaar), de weinig centrale ligging van de SVB, het feit dat men alleen op afspraak en bovendien slechts onder werktijd bereikbaar is.

\subsubsection{Scholingsprojecten}

In de Euregio Maas-Rijn is momenteel sprake van een beperkt aantal grensoverschrijdende scholingsprojecten. Deze projecten zijn voornamelijk op initiatief van opleidingsinstanties en branche-organisaties tot stand gekomen. In de Euregio is in het verleden een aantal arbeidsbureaus betrokken geweest bij het Euregionaal Vakopleidings Experiment (EVE-)project. Dit project betrof beroepsopleidingsexperimenten op het gebied van CNC-draaien en -fresen, en een opleiding tot in- en uitklaringsdeclarant. Voor beide projecten zocht men naar aansluiting op de hoogste eisen die worden gesteld in de verschillende landen. Beide projecten zijn echter doodgebloed omdat de medewerking van de verschillende participanten achterbleef bij de toezeggingen en er bovendien sprake was van een uiterst geringe belangstelling van de kant van bedrijven en cursisten.

Momenteel zijn er aanzetten tot samenwerking op het gebied van Euregionale opleidingen in:

- de gezondheidszorg (Provinciale Ziekenhuisraad, Hogeschool Sittard);

- Hoger Economisch en Administratief Onderwijs (Fachhochschule Aachen en Hogeschool Heerlen);

- procestechnologie en computersimulatie (Stichting Technologiecentrum Limburg en Vervolmakings Instituut Industriële Applicaties);

- metaalbewerking (IHK Aachen en SOM Heerlen).

In Noord-Limburg werkt het Arbeidsbureau Venlo samen met de Arbeitsamter van Mönchen Gladbach, Krefeld en Wesel in het project Scholing Internationaal Chauffeur. De start van dit uit het Interregprogramma gefinancierde project zal plaatsvinden in september 1991.

In 1987 is in de Euregio Twente-Westmünsterland de Stichting GrensOverschrijdende Beroepsopleiding (SGOB) opgericht. SGOB is een stichting naar Nederlands recht met tevens Duitse rechtspersoonlijkheid, met als doel het ontwikkelen, opstarten, begeleiden en in stand houden van grensoverschrijdende opleidingen en cursussen. Het SGOB-bureau telt momenteel tien medewerkers en biedt lesprogramma's aan op het gebied van Metaal, Textiel en Milieu-techniek. De achterliggende idee daarbij is dat door samenwerking en afstemming op het gebied van opleidingen, scholing en examinering, er langzamerhand een gelijkschakeling op opleidingen van vaklieden ontstaat, waardoor de mobiliteit van werknemers zou kunnen toenemen. Sedert april 1989 heeft de Euregio Twente-Westmünsterland een projectleider voor arbeidsmarkt en beroepsopleiding in dienst. Deze heeft, samen met SGOB cursussen tot ontwikkeling gebracht op het gebied van:

- plaatbewerking;

- modelmakerij en gieterij;

- betonstaal vlechten en buigen;

- lassen;

- kunststofindustrie; 
- bouw;

- opleidingen voor hotel en restaurant en toerisme;

- de zorgsector (ziekenhuizen, bejaardentehuizen);

- agrarisch onderwijs;

- grensexpeditie.

Voor de financiering van de opleidingen wordt gebruik gemaakt van kaderregelingen voor scholing en arbeidsinpassing, opleidings- en ontwikkelingsfondsen, subsidieregelingen van provincies en financiering op basis van het Arbeitsförderungsgesetz.

\subsection{OVERZICHT VAN ACTIVITEITEN}

De in dit hoofdstuk aangehaalde bestaande activiteiten en (beleids)initiatieven worden samengevat in schema 2. Een vergelijking van het knelpuntenoverzicht met het schema van initiatieven en samenwerkingsprojecten leidt tot de conclusie dat de meeste initiatieven op het terrein liggen van de informatievoorziening, in beperkte mate aangevuld met bijstandverlening, of betrekking hebben op kennismaking en uitwisseling. Daarnaast zijn er ook initiatieven op het terrein van de beroepsscholing. Het accent op de informatievoorziening in de bestaande initiatieven stemt overeen met de door Soeters (1991) aangegeven levensfases in de Euregionale netwerkvorming. Het is daarbij opmerkelijk dat rond de meest weerbarstige knelpunten, wetgeving en uitvoeringsprocedures met betrekking tot belastingen en sociale zekerheid, nog nauwelijks initiatieven zijn ontplooid, die daadwerkelijk tot het opheffen van deze knelpunten zouden kunnen leiden.

Een tweede conclusie die zich opdringt en waarop ook in veel gesprekken is gewezen, is de verbrokkeling van de initiatieven vanuit gescheiden circuits van vakbonden, arbeidsvoorziening en particulieren. Deze verbrokkeling brengt het gevaar met zich mee dat door de concurrentie van organisaties met vergelijkbare ideeën, de aandacht wordt afgeleid van het verkrijgen van interne overeenstemming en inhoudelijke samenhang.

Een derde cluster van conclusies is gebaseerd op de resultaten van de eerder genoemde enquête van COA-Limburg en richt zich in het bijzonder op grensoverschrijdende scholingsprojecten:

- het zijn vooral instellingen uit het hoger (beroeps-)onderwijs die participeren in grensoverschrijdende samenwerkingsprojecten;

- slechts enkele projecten (van arbeidsbureaus, leerlingwezen, HBO-instellingen) richten zich op daadwerkelijke integratie van les-, stage- en examenprogramma's;

- zeer veel Nederlandse opleidingsinstellingen zeggen op zoek te zijn naar mogelijkheden tot samenwerking. Het ontbreekt echter veelal aan concrete aangrijpingspunten voor terreinen waarop inhoudelijk zou kunnen worden samengewerkt;

- ondanks de taalverschillen is er vooral sprake van samenwerkingsprojecten tussen Nederlandse en Duitse partners. De samenwerking in de Belgisch-Nederlandse grensstreek is op het gebied van onderwijs en scholing daarentegen nog zeer gering. 


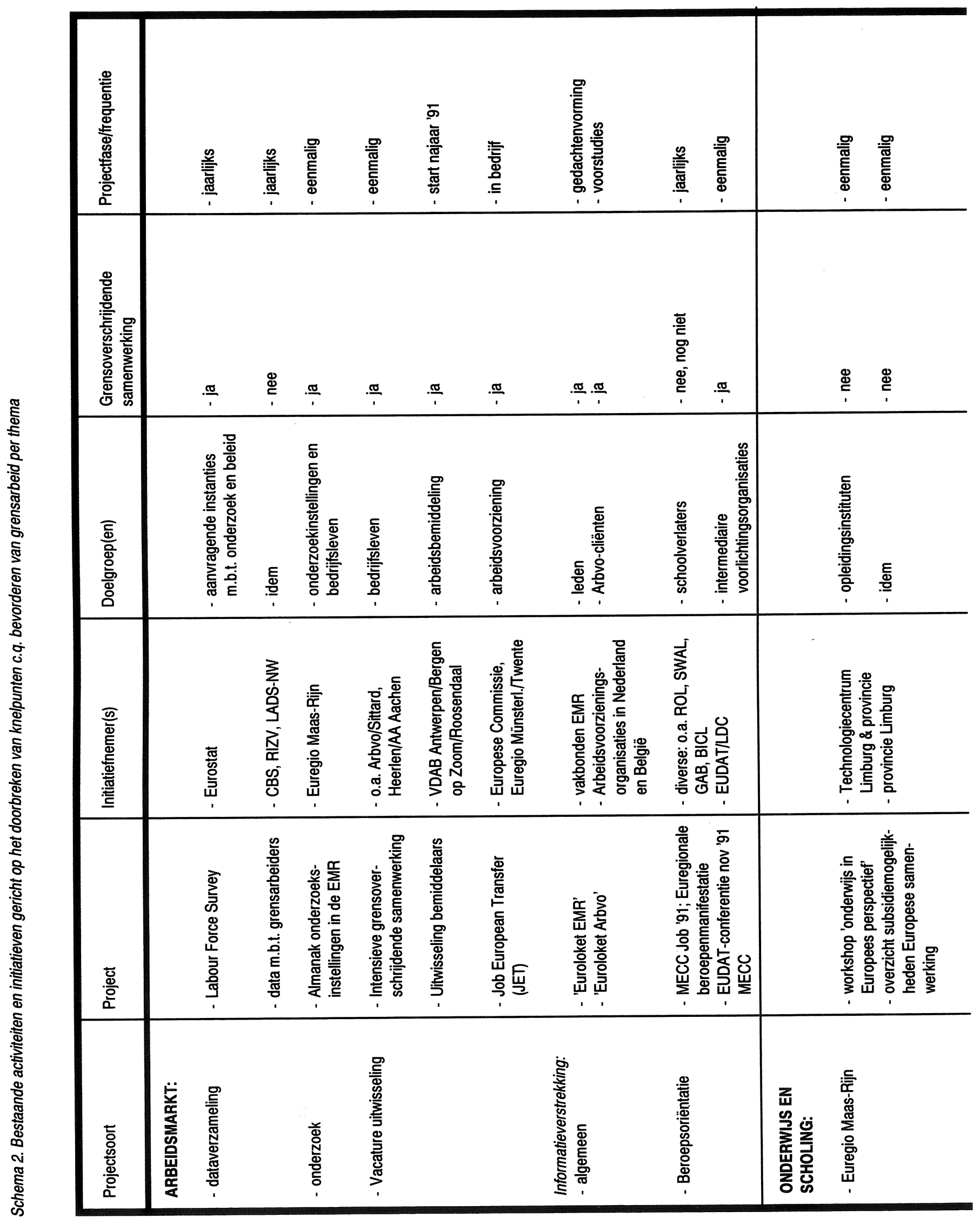




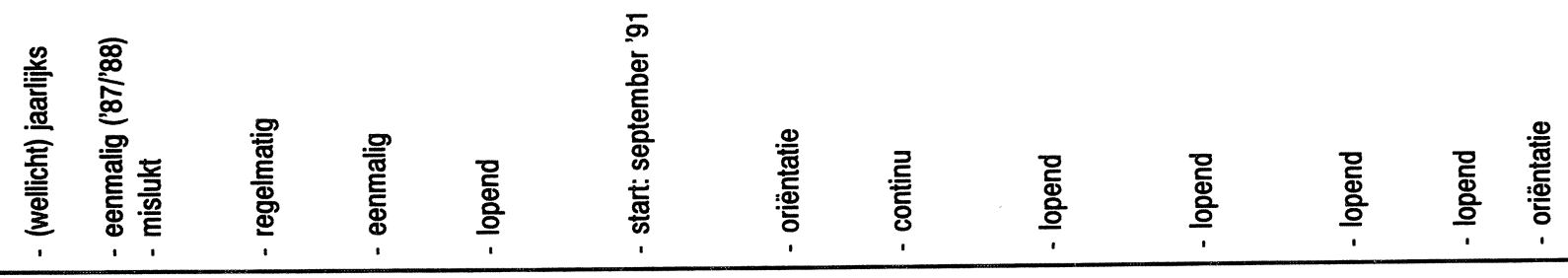
$\therefore$
으
ㅇ․
뜨 $\quad$ 뜨. 뜨
음
프 프

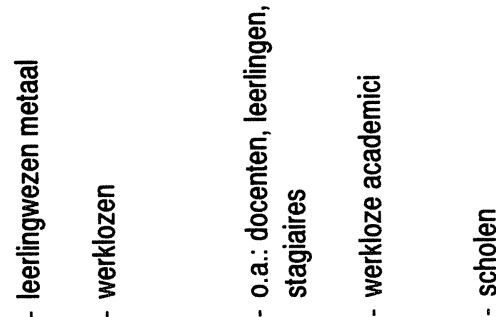

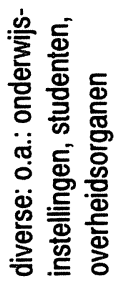

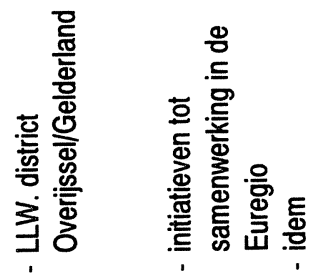

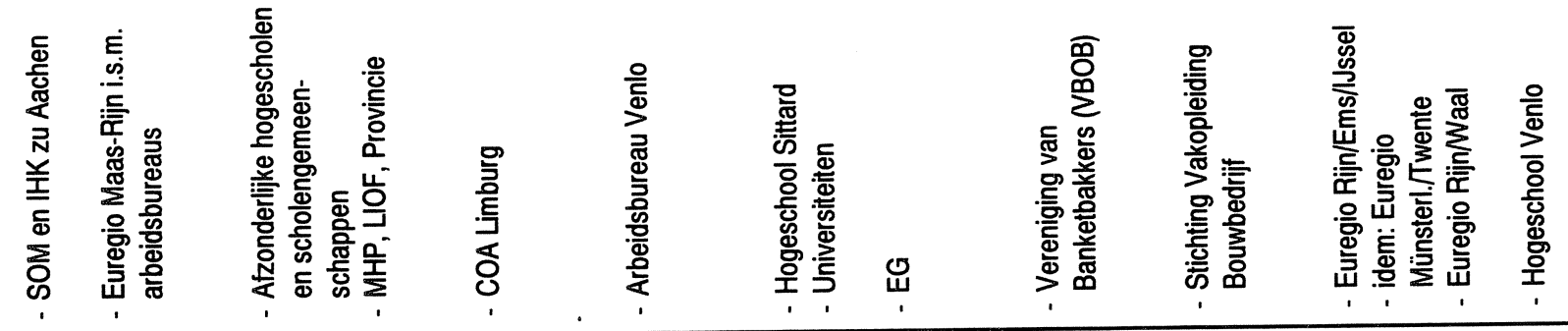

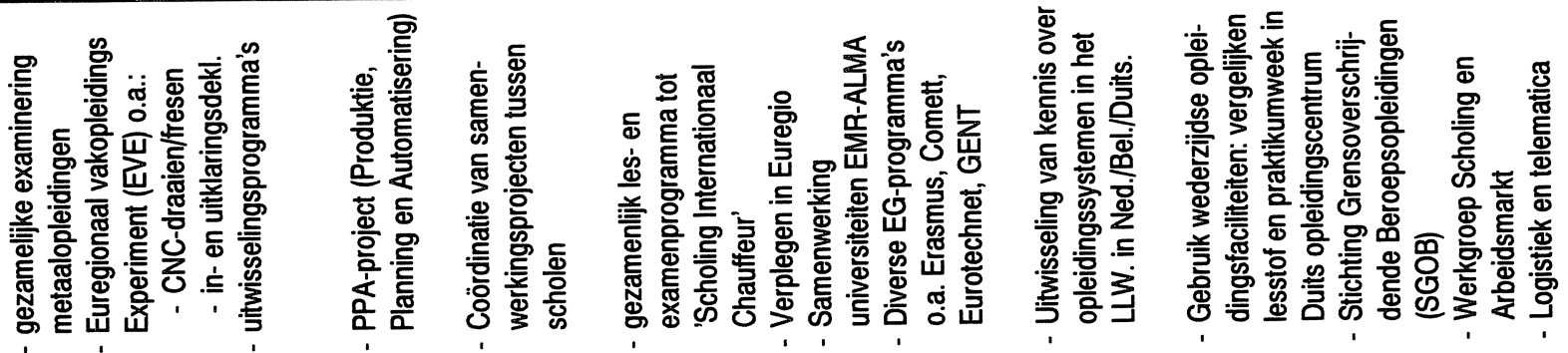




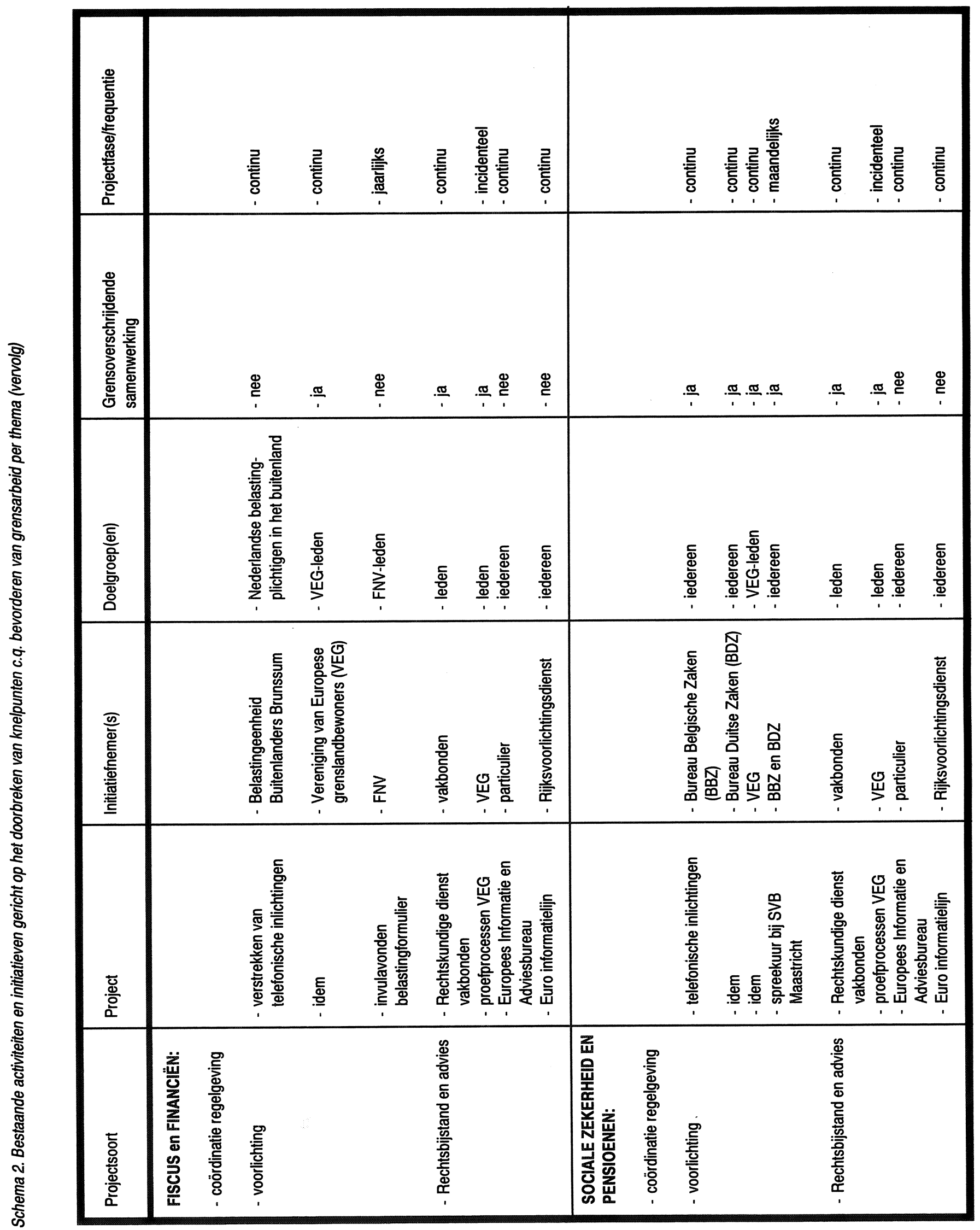




\section{AANGRIJPINGSPUNTEN VOOR BELEID}

\subsection{INLEIDING}

Tijdens het onderzoek is een groot aantal suggesties voor (verdere) beleidsontwikkeling naar voren gekomen in de gesprekken met pendelaars, belangenbehartigers, ambtelijke en wetenschappelijke deskundigen en leden van de begeleidingscommissie. Ook zijn enkele suggesties overgenomen uit de geraadpleegde onderzoekrapporten en beleidsnota's. In dit hoofdstuk wordt een overzicht gegeven van de diverse mogelijkheden voor beleidsontwikkeling, zoals die uit dit onderzoek naar voren zijn gekomen. Deze zijn, afgezien van enkele algemene beleidssuggesties, gerangschikt naar de vier themagebieden (zie paragraaf 5.3.). Vooralsnog is gestreefd naar een zo groot mogelijk aantal suggesties. Eerst wordt echter in paragraaf 5.2 . ingegaan op een aantal aandachtspunten, waarmee bij de beleidsontwikkeling rekening zou moeten worden gehouden.

\subsection{ALGEMENE AANDACHTSPUNTEN VOOR DE BELEIOSONTWIKKELNG}

In deze paragraaf zal een negental meer algemene aandachtspunten worden aangestipt, die van belang zijn voor de invulling van het beleidskader van waaruit concrete beleidsvoorstellen, gericht op de totstandkoming van een Euregionale arbeidsmarkt kunnen worden geformuleerd. Het gaat daarbij om de volgende aandachts- c.q. uitgangspunten.

\section{Visie op Euregio als bestuurlijke entiteit}

Geconstateerd kan worden dat de gedachtenvorming over Euregionale samenwerking zich nog steeds in een zeer pril stadium bevindt. Er is derhalve nog nauwelijks sprake van (een aanzet tot) een politieke visie op de mogelijkheden en wenselijkheden van de Euregio Maas-Rijn als bestuurlijke eenheid. Euregionale samenwerking kan pas werkelijk gestalte krijgen nadat hierover in de participerende grensregio's enige consensus is bereikt.

\section{Motiverend beleidskader}

In het rapport van de Commissie 'Toekomst Limburg' (Buck, 1990) wordt een pleidooi gehouden voor het creëren van een wervend vestigingsmilieu voor bedrijven in de provincie Nederlands Limburg, op basis van onder meer een 'Deltaplan voor de Limburgse arbeidsmarkt'. Een soortgelijke missie zou een kader kunnen bieden voor de positionering van de verschillende beleidsinitiatieven die bijdragen aan de totstandkoming van een Euregionale arbeidsmarkt. Op deze wijze zou ook een positieve bijdrage kunnen worden geleverd aan de beeldvorming van de Euregio Maas-Rijn, zowel bij de bevolking en de bedrijven binnen de Euregio, als met betrekking tot het imago van de Euregio naar buiten toe.

\section{Bezinning op succes- en faalfactoren van samenwerking}

De grensoverschrijdende netwerkvorming loopt het gevaar te blijven steken in het genereren van op zich kansrijke ideeën, waarvan de verdere ontwikkeling stagneert. In de organisatiekundige literatuur met betrekking tot netwerkvorming en relatievorming tussen verschillende partners worden de volgende fasen beschreven (zie Soeters, 1991): 
- 'nulfase': signalering van gemeenschappelijkheid en wederzijdse afhankelijkheid.

- expressiefase: uitdrukken van wederzijds respect, vertrouwen en gemeenschappelijke interesses.

- informatiefase: uitwisseling van informatie en nieuwe ideeën en de ontwikkeling van gezamenlijke onderzoeks- en informatie-uitwisselingsprojecten.

- produktie- of joint-venture fase: produceren en distribueren van gezamenlijke goederen.

- integratiefase: geheel of gedeeltelijke herverdeling van invloed, macht, middelen en bevoegdheden.

De expressiefase vereist strategische en diplomatieke vaardigheden van de netwerkvormers. Voor de verdere ontwikkeling van ideeën zijn de juiste experts en de juiste informatie noodzakelijk. In de produktie- of joint venture fase moet er een verschuiving plaatsvinden van de 'top' van het netwerk naar de werkvloer en het gewone, alledaagse management. Netwerkvorming loopt het gevaar in de informatiefase te blijven steken. In dit hoofdstuk zal een poging worden ondernomen om beleidsinitiatieven aan te dragen op basis waarvan de stap van de informatiefase naar de produktiefase kan worden gezet.

Men kan zich echter afvragen of op dit moment de integratiefase reeds aan de orde is, aangezien geconstateerd moet worden dat er van een ontwikkelde en breed gedragen visie op een Euregionale bestuurlijke entiteit feitelijk nog geen sprake is. Voor de integratiefase is naast een overdracht van activiteiten en verantwoordelijkheden vooral ook de culturele dimensie van belang. Uit internationaal vergelijkend onderzoek (Hofstede, 1980 en Schreuder, 1990) blijkt de culturele factor van grote betekenis te zijn voor de slaagkans van internationale samenwerkingsprojecten. Meer in het algemeen kunnen de volgende voorwaarden voor het slagen van samenwerkingsprojecten worden geformuleerd (zie Grooten, 1991):

- gemotiveerde partners, zowel vanuit 'het beleid' als vanuit 'het veld';

- een goed gedefinieerd project, met meetbare doelstellingen;

- goed verdeelde rollen en een duidelijk projectmanagement;

- goede administratieve ondersteuning;

- adequate financiering.

\section{Aandacht voor potentiële pendelaars}

Het kan bij de beleidsontwikkeling van belang zijn om onderscheid te maken tussen de positie van de huidige pendelaars en de mogelijkheden die er zijn voor potentiële pendelaars. Bij deze laatste groep kan men zowel denken aan werkenden als aan werklozen, herintreders en schoolverlaters. Bovendien kan men nog een onderscheid maken tussen degenen die op zoek zijn naar een baan (loontrekkenden) en degenen die zich als zelfstandige in een buurland zouden willen vestigen.

Bij het te voeren beleid is het van groot belang dat de doelgroep van potentiële pendelaars een belangrijke plaats inneemt bij zowel de informatieverzameling, de informatieverstrekking, de arbeidsbemiddeling, de (bij)scholing, e.d. Eventueel kan men daarbij denken aan een specifiek beleidstraject ten aanzien van deze doelgroep.

\section{Aandacht voor MKB en zelfstandigen}

Het vermoeden lijkt gerechtvaardigd te zijn dat vooral het midden- en kleinbedrijf en de zelfstandigen specifieke deskundigheid missen met betrekking tot de knelpunten en de mogelijkheden van het aanstellen van werknemers uit buurlanden. Een op deze, relatief omvangrijke, groep gericht informatie- en voorlichtingstraject ontbreekt nagenoeg geheel. Daarbij zou ook nagegaan moeten worden welke knelpunten er bestaan ten aanzien van vestigingsvoorwaarden en specifieke beroepsregulerende maatregelen. Hierover dient overleg 
gevoerd te worden met branche- of beroepsorganisaties. Tevens dient een op deze doelgroep gericht voorlichtingstraject ontwikkeld te worden. Daarbij zou aangesloten kunnen worden bij de bestaande informatienetwerken van de Kamers van Koophandel.

\section{Netwerkvorming in de Euregio en tussen Euregio's}

Er bestaat binnen de Euregio Maas-Rijn nog een grote onbekendheid met de structuur van de overheidsdiensten en aanverwante organisaties in de grensgebieden. $\mathrm{Er}$ moet in dit verband worden opgemerkt dat de informatievoorziening over de Euregio Maas-Rijn nog gering is in vergelijking met de situatie in enkele andere Euregio's. Er dient dan ook een actiever informatiebeleid gevoerd te worden, waarmee de Euregio Maas-Rijn zich zowel binnen als buiten de Euregio kan profileren. Na gedurende een half jaar een wekelijks overzicht van publikaties uit de lokale media over provinciaal politiek-bestuurlijk nieuws te hebben gevolgd, moet helaas geconstateerd worden dat de Euregio Maas-Rijn nog nauwelijks een issue is in de lokale media. In vergelijking met bijvoorbeeld de tweemaandelijkse knipselkrant die door de Euregio TwenteWestmünsterland voor alle burgers in dat gebied wordt uitgegeven, is dat ietwat mager.

Voor de samenwerking tussen de Euregio's onderling bestaat sedert 1971 de Werkgemeenschap Van Europese Grensgebieden (WVEG) die haar secretariaat heeft bij de Euregio TwenteWestmünsterland. Ter ondersteuning van de activiteiten van deze werkgemeenschap heeft de Europese Commissie, naast het INTERREG-programma, het LACE-programma opgezet: Linkage Assistence and Cooperation for the European Border Regions. Met dit programma wordt beoogd om informatie-uitwisseling, samenwerking en externe belangenbehartiging van Euregio's tot stand te brengen.

De politici uit de Euregio dienen zich niet alleen in de Euregio als pleitbezorgers voor de belangen en problemen van grenslandbewoners te profileren, maar vooral ook in de nationale en internationale fora, waar de voor grensregio's relevante besluitvorming plaats vindt. Een netwerk van (Euro-)parlementariërs uit de grensgebieden zou wellicht mogelijkheden bieden tot beïnvloeding van de besluitvorming op Europees en nationaal niveau.

\section{Mogelijkheden voor beleidsactoren voor 'incentive-sturing'}

Per beleidsthema zou nagegaan moeten worden wat de mogelijkheden zijn voor de betrokken overheids- en uitvoeringsinstanties, om 'incentives' te creëren in de huidige subsidiestromen e.d. die op termijn zouden kunnen bijdragen aan de totstandkoming van een Euregionale arbeidsmarkt. Daarvoor zou een forum samengesteld moeten worden van gezaghebbenden op het terrein van de financiën van (Eu-)regionale overheidsinstanties. Deze zouden vóór aanvang van het nieuwe begrotingsjaar 1993 met een pakket voorstellen moeten komen. In aansluiting daarop zou een halfjaarlijks gestructureerd overleg kunnen worden opgezet tussen overheden, indien gewenst aangevuld met de sociale partners in de Euregio. Vanuit dit overleg zou kunnen worden toegewerkt naar een verdere invulling van een dergelijk beleid.

Daarnaast kan wellicht worden gedacht aan Euregionale fondsvorming vanuit de begrotingen van de deelnemende regio's, voor een directe financiering van mobiliteitbevorderende maatregelen e.d.. Door Euregionale bestuurders (Gouverneursoverleg) zouden de mogelijkheden hiertoe verkend moeten worden. Het wordt de diverse organisaties in 'het veld' (arbeidsvoorziening, onderwijs, e.d.) thans in feite onnodig moeilijk gemaakt, omdat initiatiefnemers van projecten die mede door de Europese Gemeenschap worden gefinancieerd, bij meerdere bij de Euregio betrokken overheidsinstanties, eenzelfde subsidieverzoek moeten indienen en verdedigen, al dan niet aangepast aan specifieke, regionale criteria voor subsidieverstrekking. De energie, die momenteel gestoken wordt in de 'dans om de Euregionale middelen', kan beter besteed worden aan het verkrijgen van inhoudelijke overeenstemming tussen de deelnemende partners en het verkrijgen van Europese subsidies. 


\section{Een juridisch (bestuursrechtelijk) kader voor samenwerkingsprojecten}

Sinds kort bieden het Benelux-verdrag (in werking getreden op 1 april 1991) en het 'SchlossAnholt Akkoord' (ondertekend in mei 1991, ratificatie medio 1992) een staatsrechtelijk kader voor de samenwerking tussen respectievelijk Belgische en Nederlandse overheden en Nederlandse en Duitse overheden. Deze samenwerking vond tot op heden plaats op informele of privaatrechtelijke basis. De bovengenoemde verdragen maken het mogelijk om een publiekrechtelijk lichaam te creëren, op basis van een gemeenschappelijke regeling. Een dergelijk openbaar lichaam heeft echter alleen indirekt, via de verordeningen van deelnemende overheden, de mogelijkheid om verplichtende regels voor te schrijven en of heffingen op te leggen. Het mag hierbij echter alleen gaan om een herverdeling van bestaande bevoegdheden. De voordelen van dergelijke publiekrechtelijke samenwerkingsverbanden liggen onder meer in het feit dat ze als zelfstandig rechtspersoon kunnen opereren. Bovendien kan op deze wijze structuur en bestendigheid worden gegeven aan samenwerkingsrelaties en meer mogelijkheden worden gecreëerd voor een democratische controle. De verdragen bieden echter ook mogelijkheden voor minder vergaande vormen van samenwerking op afzonderlijke beleidsterreinen (bijvoorbeeld waterhuishouding, afvalverwerking, infrastructuur en scholing).

Nagegaan zou moeten worden of er een vergelijkbaar bilateraal verdrag bestaat tussen Duitsland en België en vervolgens, of het wenselijk en politiek haalbaar is om tot een publiekrechtelijke organisatie voor de Euregio Maas-Rijn (thans een stichting naar Nederlands recht) te komen. Ook kunnen samenwerkingsorganisaties, waar wenselijk, in het leven worden geroepen voor een afzonderlijk beleidsterrein.

\section{Aanpassen wet- en regelgeving}

De bij de Euregio Maas-Rijn betrokken overheidsinstanties dienen, voor zover zij betrokken zijn bij de totstandkoming of uitvoering van wetten en regelingen, alert te zijn op impliciete of expliciete beperkingen voor grensoverschrijdende activiteiten. Dit kan bijvoorbeeld betrekking hebben op de verzekering voor ziektekosten of aansprakelijkheid voor pendelwerknemers (waarbij soms sprake is van een expliciete beperking van de werkingssfeer tot het nationale grondgebied) of tot de toelatingsvoorwaarden voor een opleiding of een scholingsproject (waarbij de toelating beperkt is tot enkele met name genoemde vooropleidingen). Hoewel op voorhand gesteld kan worden dat veel van dergelijke beperkingen ontoelaatbaar zijn ten opzichte van de juridisch hogere Europese rechtsbeginselen, zal het voor individuele burgers die hiermee worden geconfronteerd een erg lange weg zijn om hun recht te halen. Erkend moet worden dat de verantwoordelijkheid voor het vermijden van fricties ten opzichte van hogere Europese rechtsbeginselen dan ook dient te liggen bij de nationaal, regionaal of lokaal werkende overheden of instanties die betrokken zijn bij de totstandkoming of uitvoering van dergelijke beperkende bepalingen in wetten, regelingen of voorschriften.

Nog onlangs is in de Duitse deelstaat Nord-Rhein Westfalen door de SPD een wetsontwerp voorgesteld voor de zogeheten 'Pflegebeschaffung' (in Nederland: AWBZ). Hierin komen de volgende bepalingen voor: In artikel 6 wordt bepaald dat iedereen die in Duisland woont of werkt in het fonds dient bij te dragen. In artikel 4 wordt gesteld dat de verstrekkingen (bijvoorbeeld hulp bij huishouding of verpleging) alleen in het binnenland genoten mogen worden. Bovendien kunnen verstrekkingen alleen gedaan worden aan diegenen die vijf jaar of langer een Duitse woon- of vestigingsplaats hebben (artikel 10).

In dit verband moet ook worden opgemerkt dat er bij het opstellen van nieuwe regelgeving of het wijzigen van bestaande nationale regelgeving nog weinig gebruik lijkt te worden gemaakt van deskundigen op het gebied van de grensoverschrijdende samenwerking. 
Eén van de geïnterviewde deskundigen merkte hierover het volgende op: De positie van de Stichtingen Bureau Belgische Zaken (BBZ) en Bureau Duitse Zaken in het proces van regelgeving is erg gering, terwill de Stichtingen toch zeer deskundig zijn op het gebied van de grensarbeid. De voorstellen van de Stichtingen voor wijzigingen van bepaalde regels worden op centraal niveau nogal eens stiefmoederlijk behandeld. Meestal wordt de Stichtingen trouwens helemaal niets gevraagd en blijken de problemen voor grensarbeiders pas op het moment dat alle regiokantoren al druk bezig zijn met het doorvoeren van de nieuwe of gewijzigde regels'.

\subsection{BELEIDSSUGCESTIES}

\subsubsection{Algemene beleidssuggesties}

\section{Dataverzameling en onderzoek}

Op het niveau van de Euregio ontbreken, zoals reeds eerder is opgemerkt, momenteel elementaire sociaal-economische statistieken en kernindicatoren met betrekking tot het functioneren van de arbeidsmarkt. De beschikbare cijfers zijn zeer globaal en hebben betrekking op een breder gebied of zijn onderling onvoldoende vergelijkbaar door afwijkende classificaties, meetinstrumenten e.d.. Door onderzoekinstituten in de Euregio zou, in samenwerking met het statistisch bureau van de Europese Gemeenschap Eurostat, een onderzoekinstrument ontwikkeld moeten worden dat voorziet in de databehoefte in de Euregio. Daarbij zou ook een beroep gedaan kunnen worden op de medewerking van de universiteiten in de Euregio.

Bij de te ontwikkelen Euregio-Statistiek zou moeten worden uitgegaan van de volgende uitgangspunten:

- de statistiek moet zoveel mogelijk aansluiten bij de huidige statistieken van Eurostat en de bestaande regionale statistieken;

- de statistiek moet zoveel mogelijk tegemoet komen aan de behoeften van de diverse gebruikers: provinciale overheden, arbeidsvoorziening, bedrijfsleven, vakbonden etc..

- de dataverzameling geschiedt onder verantwoordelijkheid van de verschillende regionale onderzoeksinstellingen. De wijze waarop dit gebeurt wordt vastgesteld in een samenwerkingsverband waarin naast vertegenwoordigers van de vier deelregio's ook een vertegenwoordiger van Eurostat zit.

De Euregio-statistiek zou in ieder geval de volgende onderdelen uitgesplitst naar deelregio moeten bevatten:

1. Bevolking:

2. Economische structuur:

3. Beroepsbevolking:
- bevolkingsopbouw naar leeftijdsgroep en geslacht;

- interregionale migratie binnen de Euregio.

- aantal werknemers per bedrijfstak;

- bruto toegevoegde waarde per bedrijfstak;

- bruto-investeringen per bedrijfstak.

- aantal werknemers naar opleidingsniveau en -richting;

- instroom schoolverlaters op de arbeidsmarkt naar opleidingsniveau en -richting;

- aansluiting onderwijs-arbeidsmarkt van schoolverlaters;

- idem, prognoses voor de komende drie tot vijf jaar. 


\section{Arbeidsmarkt}

5. Pendelarbeid:
- aantal werklozen naar leeftijdsgroep, geslacht, opleidingsniveau en -richting;

- idem, geharmoniseerd percentage (kort- en langdurig) werklozen;

- openstaande vraag naar opleidingsniveau en -richting.

- aantal pendelaars naar herkomst- en bestemmingsregio.

De gegevens vermeld onder 1, 2 en voor een beperkt deel 4 zijn beschikbaar via Eurostat, zij het niet altijd op het gewenste regionale niveau. Door aanvullende gegevens te gebruiken van de nationale statistische bureaus, moet het echter mogelijk zijn om schattingen te maken voor de betreffende deelregio's. Het gebruiken van Eurostat-gegevens als vertrekpunt, heeft als belangrijk voordeel dat de wijze van dataverzameling, classificatie e.d. zoveel mogelijk uniform verloopt.

Voor de overige gegevens geldt dat een dergelijke uniformiteit in meetinstrumenten en classificatie ontbreekt. Databronnen zijn hier onder meer: de nationale statistische bureau's, de regionale arbeidsvoorziening, de ziekenfondsen en de belastingdiensten. Zo zouden de gegevens met betrekking tot de grensarbeiders die beschikbaar zijn bij de sociale zekerheidsinstanties, voor zover deze op basis van uniforme criteria worden geclassificeerd, een betrouwbaar beeld kunnen geven van de omvang en de aard van de pendelstromen en de ontwikkeling hiervan.

Om een adequaat inzicht te krijgen in de ontwikkeling van de economische structuur van de Euregio, zou het ook zeer wenselijk zijn te komen tot een stelsel van Euregionale Rekeningen in de vorm van input-output tabellen van de inter- en intrasectorale leveranties. Een dergelijke informatiebron maakt het mogelijk de effecten in beeld te brengen van beleidsvoorstellen op sociaal-economisch terrein in het algemeen en het vestigingsbeleid in het bijzonder.

Op dit moment is op een aantal onderdelen reeds summiere informatie voorhanden. Zo zijn er globale statistieken over grensarbeiders, hun herkomst- en hun bestemmingsregio's beschikbaar. Verder zijn een aantal gegevens over de economische structuur en de werkgelegenheid bekend. De gegevens over de bevolkingsopbouw en de beroepsbevolking zijn bij de nationale en/of regionale onderzoeksbureaus aanwezig. Hoewel er door EUROSTAT, het statistische bureau van de Europese gemeenschap wel pogingen worden ondernomen om tot een geïntegreerde en gedetailleerde Europese Statistiek te komen, stuit de ontwikkeling hiervan op weerstanden van nationale instellingen. De ontwikkeling van een Euregio Statistiek zou een katalyserende werking kunnen hebben op de integratie op Europees niveau.

In eerste instantie zou een inventariserend onderzoek moeten worden gehouden waarin een nauwkeurig beeld wordt geschetst van de statistische informatiebehoefte bij de verschillende doelgroepen in de Euregio. Tevens zou moeten worden onderzocht welke informatie direct of indirect beschikbaar is en wat de mogelijkheden zijn om door coördinatie van bestaande meetinstrumenten of het opzetten van nieuwe meetinstrumenten (zoals bijvoorbeeld de RUBSschoolverlatersenquête) aan de informatiebehoefte te voldoen.

De ontwikkeling van een Euregio Statistiek zal een uitstekende voedingsbron kunnen vormen voor de activiteiten met betrekking tot de onderlinge afstemming van de diplomavergelijking enerzijds (in het kader van bijvoorbeeld de verstrekking van vestigingsvergunningen voor zelfstandigen) en de ontwikkeling van onderwijsclassificaties anderzijds. Voor een dergelijke afstemming zal een vorm van coördinatie tot stand moeten worden gebracht mét een mogelijke positieve kruisbestuiving tot gevolg. 


\section{Verbetering van kwaliteit en distributie van voorlichtingsmateriaal}

Ten aanzien van het beschikbare schriftelijke informatiemateriaal over fiscaliteit en sociale zekerheid kan het volgende worden geconcludeerd:

- er is relatief veel schriftelijke informatie beschikbaar over met name de belangrijkste fiscaleen sociaal-juridische gevolgen van de pendelarbeid van België naar Nederland of Duitsland en van Nederland naar Duitsland. Deze informatie is echter op weinig plaatsen verkrijgbaar. Bovendien is dit materiaal veelal opgesteld ten behoeve van intern, ambtelijk gebruik, waardoor het materiaal niet erg geschikt is voor het geven van voorlichting. Een uitzondering moet hierbij gemaakt worden voor de Vlaamse ACV en de Waalse CSC die voor de Belgische pendelaars in Nederland en Duitsland zeer handzame brochures hebben samengesteld. Hetzelfde is gedaan voor Nederlandse en Belgische pendelaars door het Benelux-bureau te Brussel. De VEG verstrekt zeer toegankelijke informatie voor Nederlandse pendelaars in Duitsland;

- er is nauwelijks schriftelijke informatie beschikbaar over de (fiscale en sociaal-juridische) gevolgen van het wonen in Duitsland en het werken in België of Nederland en er is relatief weinig informatie beschikbaar over het wonen in Nederland en het werken in België.

- de beschikbare schriftelijke informatie beperkt zich veelal tot een (gebruikersonvriendelijke) vergelijking van de fiscale en sociaal-rechtelijke regelingen. Van het 'menugewijs' aanbieden van korte 'informatieblokken' wordt nog geen gebruik gemaakt;

- er lijkt sprake te zijn van gescheiden circuits van informatieverstrekking vanuit een aantal betrokken instanties: vakbonden, arbeidsvoorziening en particuliere initiatieven. Een dergelijke verbrokkeling maakt het enerzijds onduidelijk waar men voor een bepaalde informatievraag het beste terecht kan en belemmert anderzijds een geïntegreerd voorlichtingsbeleid;

- de informatievoorziening voor werkgevers en afdelingen P\&O in hun hoedanigheid van werkgever van pendelaars en in hun hoedanigheid als mogelijk intermediair naar werknemers/pendelaars is minimaal. Ook bij grote arbeidsorganisaties ontbreekt het aan kennis over de belangrijkste instanties op dit gebied.

De gevolgen van het pendelen van België naar Nederland of Duitsland en het pendelen van Nederland naar Duitsland zijn goed in beeld gebracht. Er zijn daarentegen weinig rapporten of brochures aangetroffen, waarin de gevolgen van de omgekeerde pendel worden geïnventariseerd. Dit hangt waarschijnlijk samen met het feit dat van dergelijke pendelstromen nog nauwelijks sprake is.

Door meerdere respondenten is opgemerkt dat de informatievoorziening door de overheid over Europese-, nationaleen regionale overheidsprogramma's erg versnipperd is. De volgende opmerkingen zijn veelzeggend: "het is toch ongelofelijk zoveel Europese programma's en subsidiemogelijkheden er alleen al zijn. Maar in de hele Euregio is er geen persoon of instantie die mij daarvan een volledig overzicht kan geven. Dan moet ik naar Brussel of Den Haag. Deze informatie zou op een centraal punt in de Euregio beschikbaar moeten zijn'. 'Op de geretourneerde vragenlijsten van de door het COA-Limburg georganiseerde enquête onder onderwijsinstellingen langs de Nederlandse grens kwam veelvuidig een opmerking voor in de trant van: Wii willen erg graag samenwerken met een school over de grens, maar hoe komen we aan de informatie en de middelen die daarvoor nodig zijn?'

De bij de Euregio aangesloten overheden zouden een resolutie moeten aannemen en deze omzetten in daden, waarin zij zich uitspreken voor een uniform, overkoepelend en geïntegreerd voorlichtingsbeleid, ten einde een verbrokkeling van de initiatieven vanuit gescheiden circuits van vakbonden, arbeidsvoorziening en particulieren te voorkomen. In dit geïntegreerde voorlichtingsbeleid wordt niet de competentie van de uitvoerende instanties of de inhoud of reikwijdte van de wetten en regelingen als uitgangspunt genomen, maar de situatie van de burgers. 
Een voorbeeld van geintegreerde voorlichting waarbij de persoontijke situatie van de burgers als uitgangspunt wordt genomen is het in Nederland ontwikkelde expertsysteem voor de Sociale Diensten met betrekking tot wetgeving en jurisprudentie over de Algemene Bijstandswet (TESSEC). Dit programma is bedoeld voor gebruik door tussenpersonen (bijstands/maatschappelijke werkers). Het Enschedese bedrif 'Oog \& Oor' heeft een vergelijkbaar programma ontwikkeld met circa 50 wetten en regelingen voor individuele subsidies, ten behoeve van de voorlichtingscentra van gemeenten in Nederland. Burgers kunnen zelf plaatsnemen achter de terminal waar zij een aantal eenvoudige vragen over o.a. leeftij, inkomen, huur en woonsituatie dienen te beantwoorden. Hiema wordt een lijst afgdrukt met subsidies waar de raadplegende burger wel of geen recht op heeft en waarom wel of niet. Tevens wordt aangegeven hoe en waar de subsidies aangevraagd kunnen worden.

Het geïntegreerde voorlichtingsbeleid dient onder meer te omvatten:

- voorlichting over de voornaamste specifiek voor grensarbeiders geldende aandachtspunten rondom het werken in het buitenland;

- voorlichting omtrent mogelijke knelpunten bij en de bestaande regelingen ten aanzien van pendelarbeid;

- voorlichting over de arbeidsmarktperspectieven in de buurlanden: bijvoorbeeld vacaturebanken, geautomatiseerde studie- en beroepskeuzevoorlichtingssystemen (zoals bijvoorbeeld het Nederlandse I-See!) e.d.;

- voorlichting aan bedrijven ten aanzien van de mogelijkheden in buurlanden personeel te werven, bijvoorbeeld informatie over werkzoekenden, schoolverlaters (zoals bijvoorbeeld de Nederlandse RUBS-schoolverlatersenquête) e.d.;

- voorlichting aan bedrijven ten behoeve van een integrale informatievoorziening en bijstandverlening aan pendelende werknemers en het initiëren van cursussen voor medewerkers personeelszaken met het oog op deze dienstverlening;

- voorlichting aan met name zelfstandigen ten aanzien van de vestiging in buurlanden;

- voorlichting ten aanzien van diplomavergelijking;

- voorlichting ten aanzien van concrete grensoverschrijdende samenwerkingsprojecten.

Het zou goed zijn wanneer bij de beleidsvoornemens in het kader van het 'Euroloket'-project, vorm wordt gegeven aan een dergelijke brede, geïntegreerde voorlichting vanuit een goed bereikbaar, centraal gelegen informatiecentrum.

Het Euroloket-project zou een eerste stap kunnen zijn in de ontwikkeling van een dienstencentrum met geintegreerde loketfuncties: een zogeheten 'civic service centre'. Ats gevolg van nieuwe technische mogelijkheden (bijvoorbeeld expertsystemen en publieksterminals) en veranderende behoeften en inzichten over dienstverlening door (lokale) overheidsinstanties worden door onder meer het Nederlandse Ministerie van Binnenlandse Zaken ideeën ontwikkeld voor moderne, goed geëquipeerde centra waar met behulp van automatisering en lijnverbindingen de burger (alle) overheidszaken direct kan afhandelen. Deze wordt daarbij terzijde gestaan door een hoog gekwalificeerde en generalistisch ingesteld 'front office'-ambtenaar (BSO/Al, 1991). Soortgelijke projecten doen zich ook voor in landen als Duitsland ('Offenes Rathaus': Einfach und Sofort) en België en in sectoren als het bankwezen en de luchtvaart.

Door de provincie Nederlands Limburg zou een haalbaarheidsstudie geïnitieerd kunnen worden naar een Limburgs 'service centre' voor grensarbeiders. Hierin zouden loketfuncties van bijvoorbeeld Belastingdienst Buitenlanders en voorlichtende- en uitvoerende organisaties op het terrein van de Sociale Zekerheid, geïntegreerd moeten worden, bijvoorbeeld door (zo mogelijk beslissingsbevoegde) medewerkers van deze diensten te detacheren bij dit service centre. Soortgelijke studies zouden door de in Euregio Maas-Rijn deelnemende Duitse en Belgische overheden geïnitieerd kunnen worden. 
In de informatievoorziening en beeldvorming naar personen en bedrijven toe dienen niet alleen de momenteel bij grensarbeid ondervonden knelpunten benadrukt te worden, maar moeten vooral de positieve aspecten van de schaalvergroting van de (Eu)regionale arbeidsmarkt, voor zowel werkenden als arbeidsorganisaties centraal staan, zoals betere ontplooiingskansen en wervingsen afzetmogelijkheden.

\section{Rol van overheden binnen de Euregio als werkgever}

Vanuit de Europese Commissie zijn enkele programma's opgezet om kennismaking en uitwisseling van personen voor bijvoorbeeld het onderwijs, arbeidsvoorzieningsorganisaties en van groepen uitvoerende en leidinggevende ambtenaren te bevorderen. De subsidiemogelijkheden blijven in veel gevallen echter onaangesproken, omdat er weinig projectvoorstellen ingediend worden. Blijkbaar spelen ook andere barrières hier een rol. Onbekendheid met het bestaan van deze subsidiemogelijkheden is hiervoor waarschijnlijk de belangrijkste reden.

In het kader van de ministersconferentie van 19 november 1991 in Maastricht zal gesproken worden over 'het management van de ambtelijke integratie'. Daarbij zal het voornamelijk gaan over de kennismaking van rijksambtenaren met relevante instanties van de Europese Commissie in Brussel. De uitwerking van de in paragraaf 5.2 genoemde bilaterale verdragen, die een juridisch kader bieden voor publiekrechtelijke samenwerkingsprojecten, zoals onlangs tussen bijvoorbeeld Nederland en Duitsland en tussen de Benelux-landen zijn afgesloten, zal op deze conferentie echter waarschijnlijk niet aan de orde komen.

De diverse overheden of (semi-)overheidsinstellingen binnen de Euregio zouden een voortrekkersrol op de arbeidsmarkt kunnen vervullen, waarbij bovendien wederzijdse kennis en begrip van de 'beleidscultuur' in de buurlanden kan worden ingepast. Met name de uitwisseling van beleidsuitvoerend personeel, e.d., middels stages c.q. detacheringen, zou daarbij een belangrijke plaats kunnen innemen. Op deze wijze kan de bekendheid met personen en procedures in het aangrenzende buitenland worden vergroot. De afdelingen personeelszaken van de bij Euregio Maas-Rijn betrokken overheden zouden een dergelijk 'Euro-Job-rotation' actieplan moeten ontwikkelen. Terreinen waarop zich inhoudelijk gezien, interessante kennismakings- en samenwerkingsmogelijkheden voordoen, zijn onderwijs, milieu, ruimtelijke ordening, verkeer, etc. Verdergaande stappen zouden kunnen zijn het in dienst nemen van buitenlanders en de personeelswerving tevens richten op buurlanden.

Ten aanzien van het in dienst nemen van buitenlanders zijn de juridische belemmeringen als gevolg van jurisprudentie aan het Europese Hof van Justitie steeds kleiner geworden. Slechts 'bepaalde werkzaamheden', waarvoor een 'bijzondere band van solidariteit ten aanzien van de staat' gevraagd kan worden, kunnen nu nog aan de eigen onderdanen worden voorbehouden.

Er bestaat echter reeds enige jaren grote verwarring over de interpretatie en de toepassing van dit zogeheten 'functionele criterium' dat het Hof van Justitie hanteert. Het is niet alleen de rechtspraak nog niet gelukt om hierin eenduidigheid aan te brengen, maar er is ook sprake van onwil of onmacht van de meeste lidstaten om hun nationale wetgeving en praktijk aan te passen. Tot op heden heeft alleen Nederland de betreffende wetgeving aangepast (Wet 20 april 1988 tot wijziging van de Ambtenarenwet 1929, idem voor militairen). Slechts voor enkele posities, die in aparte wetten zijn geregeld (vertrouwensfuncties, benoemingen door de Kroon), geldt nog het Nederlanderschap als aanstellingseis.

In Nederlands Limburg zijn reeds vele Belgen werkzaam bij bijvoorbeeld (semi)overheidsinstellingen zoals Rijkswaterstaat, het Academisch Ziekenhuis en in het universitair onderwijs. Deze werknemers hebben allen het ambtenarenstatuut. Bij gemeenten en provincies zijn echter 
nog nauwelijks buitenlanders werkzaam. Er is bovendien, althans bij de provincie Nederlands Limburg, nog nooit 'over de grens' geworven. De reden daarvoor is dat het Nederlandse aanbod voor de meeste functies ruimschoots voldoende is, terwijl voor die specialistische functies, waarvoor het moeilijk is om goede mensen te krijgen, vaak onbekend is waarnaar gevraagd moet worden bij buitenlandse werving.

België hanteert nog steeds de nationaliteitsvereiste voor vrijwel alle overheidsposities. Recentelijk zijn echter op het Vlaamse gemeenschapsniveau twee Decreten uitgevaardigd (27 maart en 30 mei 1991), zodat alle mogelijke functies in het onderwijs (inclusief de universiteiten) kunnen worden ingenomen door ingezetenen van de Europese Gemeenschap. Daarvoor is dan wel een door het Belgisch Ministerie van Onderwijs verstrekt bekwaamheidsattest of een gelijkwaardig gesteld diploma vereist. Bovendien is in oktober 1990 in het actieprogramma GENT (Gehele Europese Nederlandse Taalgebied) van de Nederlandse en Vlaamse Ministers van Onderwijs melding gemaakt van de problemen bij dubbelbenoemingen aan Vlaamse en Nederlandse instellingen. Deze kunnen vaak niet tot stand komen als gevolg van voorschriften met betrekking tot de uitoefening van nevenwerkzaamheden.

In Duitsland wordt in het Bundesbeamtes-Rahmengesetz een onderscheid gemaakt tussen Beamten en Angestellten. Beamten worden benoemd en hebben een geheel andere rechtspositie (bezoldiging, staatspensioen) dan Angestellten. Voor een positie als Beamte is de Duitse nationaliteit vereist. Ingezetenen van andere EG-lidstaten kunnen echter wel in de positie van Angestellte benoemd worden. Het gaat hierbij veelal om banen in het onderwijs, ziekenhuizen, verpleeghuizen, universiteiten en andere publiekrechtelijke instellingen. Beamten kunnen in dienst zijn van de Bondsstaat (douane, belastingen, arbeidsbureaus), de deelstaten (politie, onderwijzers, justitie) of van de Kommunen/Kreisen (gemeente-ambtenaren, brandweer). Bij het Duitse Ministerie van Binnenlandse zaken wordt momenteel gewerkt aan een wetsvoorstel om ook de Beamtenposities voor EG-onderdanen toegankelijk te maken. Het zal echter zeker tot medio 1993 duren voordat dit tot wetswijzigingen op Landes-niveau geleid zal hebben.

Resumerend, kan gesteld worden dat er in alle drie betrokken landen van de Euregio Maas-Rijn in meerdere of mindere mate nog wettelijke beperkingen zijn aan de mogelijkheden tot toetreding bij een (semi-)overheidsinstantie 'over de grens'. De beperkingen zijn doorgaans groter voorzover het beleidsbepalende functies in de openbare dienst betreft. $\mathrm{Er}$ is wel sprake van wettelijke veranderingen in verband met de ontwikkeling van het Europese recht.

Het zou een goede zaak zijn, als overheidsinstellingen bij vacatures ook zouden adverteren in de media aan de andere zijde van de grens. Ook een informatieve brochure over het personeelsbeleid in het hoger onderwijs kan buitengewoon nuttig zijn. Daarin moet dan aandacht worden geschonken aan onderwerpen als personeelscategoriën, functie-inhoud en functie-eisen, aanstellingsprocedures, carrièreverloop, e.d.

De arbeidsvoorzieningsorganisaties zelf zouden binnen de Euregio een in meerdere opzichten belangrijke stap kunnen zetten door de uitwisseling van bemiddelingsfunctionarissen e.d., c.q. het werven van medewerkers in het aangrenzende buitenland. Op deze wijze wordt niet alleen de wederzijdse kennis van de verschillende beleidsculturen vergroot, maar wordt ook een bijdrage geleverd aan het vergroten van de kennis van het functioneren van de arbeidsmarkt in de buurregio's.

\subsubsection{Arbeidsmarkt}

Naast de in het vorige hoofdstuk genoemde activiteiten die in het kader van het Euroloket-project ontwikkeld worden (vacature-uitwisseling, informatievoorziening, scholing), zouden de volgende mogelijkheden uitgewerkt moeten worden. 
* Er ontbreekt een gedetailleerd, grensoverschrijdend, kwantitatief inzicht in de vraag-aanbodverhouding naar bedrijfstak, beroep en opleiding, een Euregio-statistiek. Hierdoor is een gerichte en zinvolle grensoverschrijdende vacature-uitwisseling niet mogelijk. Om hierin inzicht te krijgen is de ontwikkeling van een uniform coderings- en classificatiesysteem voor bedrijven, beroepen en opleidingen noodzakelijk (zie ook de eerstgenoemde algemene beleidssuggestie).

* Regionale kranten binnen de Euregio zouden moeten worden gestimuleerd om werkgevers in de buurlanden te informeren over advertentiemogelijkheden in hun blad. Het bureau van de Euregio Maas-Rijn zou deze stimulerende en initiërende rol op zich kunnen nemen.

* Het zou wenselijk zijn de gedrukte media van bemiddelingsorganen en particuliere instanties zoals bijvoorbeeld 'de Banenkrant', 'de Vacature-krant', in de gehele Euregio te verspreiden;

* Ook het bereik van andere wervingskanalen, zoals een vacaturetelefoon, 'Job-Link', e.d. zouden moeten worden vergroot.

* Hoewel er subsidies beschikbaar voor zijn, heeft er nauwelijks uitwisseling van bemiddelaars plaats. Het zou wenselijk zijn hieraan aandacht te schenken in het kader van het samenwerkingsproject van de arbeidsvoorzieningsorganisaties (IGA, 1991).

* Om de wervingsmogelijkheden onder Belgische en Duitse vrouwen te vergroten zou in Nederlands Limburg meer aandacht geschonken moeten worden aan randvoorwaardelijke faciliteiten die in Duitsland en België al zeer gebruikelijk zijn zoals bijvoorbeeld kinderopvang.

Om te komen tot een transparante Euregionale arbeidsmarkt, is de medewerking van het bedrijfsleven noodzakelijk. Het bureau van de Euregio Maas-Rijn, zou in haar rol als initiator en stimulator en in samenwerking met arbeidsvoorzieningsorganisaties en organisaties van het bedrijfsleven zoals de Kamers van Koophandel, de bovenstaande initiatieven op hun haalbaarheid moeten beoordelen.

Teneinde de doorzichtigheid van de Euregionale arbeidsmarkt te bevorderen, zou er jaarlijks een zorgvuldig voorbereid, tripartiet overleg plaats moeten vinden tussen overheden en werkgeversen werknemersorganisaties in de Euregio. Wellicht dat het RECITE-programma mogelijkheden biedt voor de financiering van een dergelijk initiatief.

\subsubsection{Onderwijs en scholing}

Zoals in hoofdstuk 4 werd aangegeven is er in de Euregio Maas-Rijn momenteel sprake van een aantal grensoverschrijdende scholingsprojecten. Deze projecten zijn voornamelijk op initiatief van opleidingsinstanties en branche-organisaties tot stand gekomen. Bovendien gaat het met name om projecten in de Nederlands-Duitse grensstreek. De projecten in het algemeen voortgezet onderwijs lijken zich vooralsnog meer te richten op kennismaking en uitwisseling. Bij het beroepsonderwijs lijkt er daarentegen vaker sprake te zijn van gezamenlijke scholing en examinering.

* Door het CBA wordt momenteel een haalbaarheidsstudie verricht naar de mogelijkheden voor de oprichting van een databank ten behoeve van de informatievoorziening, vergelijking en waardering van Nederlandse en buitenlandse diploma's. Indien een dergelijke databank, die tevens als centraal informatieloket zou kunnen fungeren, gerealiseerd kan worden, doet zich de vraag voor naar de inrichting van een eventueel decentraal netwerk. Met het oog hierop zou eventueel de Euregio Maas-Rijn kunnen dienen als proefveld.

* In de Euregio Maas-Rijn zou een simulatie-project opgezet kunnen worden waarin voor enkele beroepen (bijvoorbeeld: buschauffeur, verpleegkundige, lasser) wordt nagegaan wat op Euregionale schaal de gevolgen zouden kunnen zijn van naleving van de Eerste en Tweede richtlijn van diploma-erkenning. In dit verband is ook de ontwikkeling van zogenaamde 
'Assessment Centers' van belang, waarin de daadwerkelijke meting van kennis en vaardigheden plaats vindt. De haalbaarheid van een Euregionaal Assessment Center zou onderzocht moeten worden.

* Naast diplomavergelijking ten aanzien van beroepsopleidingen en de verspreiding van de informatie hierover, is vooral ook de integratie van onderwijsprogramma's van groot belang.

* Het is wenselijk een inventarisatie te verrichten naar de mogelijke wettelijke belemmeringen of andere regels (bijvoorbeeld subsidievoorwaarden) op nationaal, deelstaat, provinciaal, beroepsgroep of bedrijfstakniveau, die gezamenlijke scholingsprojecten in de weg zouden kunnen staan.

* Bij de in de Euregio Maas-Rijn betrokken subsidie-verstrekkers voor scholingsprojecten (overheden en scholingsfondsen) zou overeenstemming bereikt moeten worden over subsidiemogelijkheden en -voorwaarden (bijvoorbeeld ten aanzien van deelname en examinering) voor grensoverschrijdende scholingsprojecten. Voor de financiering van gezamenlijke scholingsprojecten kan ook gebruik worden gemaakt van nationale wetgeving zoals het Arbeitsförderungsgesetz of de kaderregelingen voor scholing en arbeidsinpassing, de beroeps- of bedrijfstakgebonden opleidings- en ontwikkelingsfondsen, en de subsidieregelingen van provincies en deelstaten. Voor een financiële bijdrage van de Europese Commissie zijn in principe diverse fondsen beschikbaar.

* Mogelijk is er in de Euregio Maas-Rijn behoefte aan een Stichting Grensoverschrijdende Beroepsopleiding, zoals recent ook in de Euregio Twente-Westmünsterland is opgericht. Daarbij doen zich vragen voor ten aanzien van de participanten, de wenselijke organisatiestruktuur, de financieringsbasis, het inhoudelijk programma, de relatie met bestaande opleidingstelsels e.d.

* Er dient een inventarisatie van de beroepsgerichte opleidingscentra in de Euregio Maas-Rijn te worden gemaakt. Daarbij dient onderscheid te worden gemaakt naar de verschillende opleidingsvormen en -terreinen. Hetzelfde zou gedaan moeten worden voor de verschillende branche- en beroepsorganisaties, zodat een gerichte vergelijking van opleidingsaanbod, opleidingsbehoefte en opleidingsmogelijkheden, per bedrijfstak, kan plaatsvinden. Op deze wijze wordt een beeld gekregen van overlappingen of hiaten in het opleidingsaanbod in de Euregio Maas-Rijn. De resultaten van deze inventarisatie zouden ten behoeve van de voorlichting naar een brede doelgroep kunnen worden opgenomen in een Vademecum of in een voorlichtingssyteem voor studie- en beroepskeuze als I-See!.

In de Euregio Twente-Westmünsterland is gebleken dat faalfactoren van scholingsprojecten kunnen liggen in:

- een minimale belangstelling van potentiële cursisten;

- het gebrekkig functioneren van lesprogramma's als gevolg van geringe beheersing van de vreemde taal;

- het voortijdig terugtrekken van cursisten als gevolg van het ontbreken van werkervaring en arbeidsritme, of vanwege het vinden van betaald werk.

Het is vanzelfsprekend van groot belang de kans op het optreden van dergelijke faalfactoren te minimaliseren.

In dit verband zouden bij de keuze van de te initiëren opleidingen de volgende criteria kunnen worden gehanteerd:

- de mate van 'Euregionale groei-potentie' van de betreffende sector of beroepsgroep;

- de mate waarin de opleiding inspeelt op het wegwerken van overschotten of tekorten op de arbeidsmarkt; 
- de mate waarin de opleiding werkzoekenden met een geringe plaatsingskans zou kunnen om-, her- of bijscholen;

- de mate waarin een opleiding inspeelt op Euregionalisering van de beroepskwalificatie: is er sprake van wederzijdse kennismaking, uitwisseling van stages en lesprogramma's of van identieke exameneisen en beroepskwalificaties?

* Naast de bestaande (initiatieven tot) scholingsprojecten op het terrein van de gezondheidszorg, het economisch- en administratief onderwijs, de procestechnologie en computersimulatie, de metaalbewerking en het transport, zouden de mogelijkheden onderzocht kunnen worden voor (samenwerking bij het opzetten van) opleidingen voor toerisme, grafische industrie, medische technologie, intensieve glastuinbouw, milieu-inspectie, en andere 'speerpunt sectoren' in deze Euregio.

* Een belemmerende factor voor potentiële pendelaars wordt altijd gevormd door een geringe taalvaardigheid. Een op te zetten opleidingscentrum zou korte, beroeps- of branchegerichte taal- en introductiecursussen kunnen organiseren. Nagegaan moet worden of de belangstelling voor dergelijke cursussen vergroot zou kunnen worden door kostprijsverlagende subsidies van de betrokken overheden, de Europese Commissie (LINGUA), of de nationale culturele instituten. Ook zou de Euregio Maas-Rijn, enigszins vergelijkbaar met het LINGUAprogramma op Europees niveau, een 'Euregionaal aktieplan regio-talen' kunnen ontwikkelen. Een eerste onderdeel daarvan zou een onderzoek kunnen zijn naar de talenkennis, het taalgebruik en de taalbehoefte en de opleidingsinfrastructuur en de opleidingsbehoefte in de Euregio.

Over het belang van cursussen taalvaardigheid blijkt zeer verschillend te worden gedacht. Aan de ene kant kon tijdens een groepsgesprek geconstateerd worden dat er bij buitenlandse werknemers een grote behoefte bestaat aan een korte, op maat gesneden beroepsgerichte taalmodule. Ook zijn er scholingsprojecten bekend waarbij de geringe taalvaardigheid achteraf werd gezien als een belangrijke faalfactor van het project. Aan de andere kant werd melding gemaakt van een minimale respons ( 4 reacties) op een inventariserend onderzoek onder bedrijven naar de behoefte aan aanvullende talencursussen.

* De ervaringen die internationaal zijn opgedaan met het 'trainen-van-trainers-project' kunnen voor de Euregio Maas-Rijn van groot belang zijn. Hierbij kan gedacht worden aan het opleiden van docenten voor nieuwe onderwijsvormen zoals 'open-leersituaties', afstandonderwijs, module-matig werken en een betere aansluiting met de persoonlijke achtergrond en voorkeuren van de studenten.

* Van groot belang voor de Euregio is de ontwikkeling en uitwisseling van onderwijstechnologie, dat wil zeggen het gebruik van informatietechnologie in onderwijssituaties. Hetzelfde geldt in iets mindere mate voor de uitwisseling van simulaties voor vaardigheidstrainingen.

\subsubsection{Fiscus en financiën; sociale zekerheid en pensioenen}

Het is van belang te constateren dat rond de meest weerbarstige knelpunten, wetgeving en uitvoeringsprocedures met betrekking tot belastingen en sociale zekerheid, noch op eEuropees noch op nationaal niveau tot nu toe veel initiatieven zijn ontplooid, die tot het opheffen van bestaande knelpunten zouden kunnen leiden. 


\section{Fiscus en sociale zekerheid}

* Met betrekking tot de uitvoering van de, in hoofdstuk 4 genoemde, bilaterale belastingverdragen tussen Nederland, België en Duitsland zou voor de pendelaars een aanzienlijke verbetering bewerkstelligd kunnen worden, als de werkgever en uitkerende instanties verantwoordelijk worden gesteld voor het aanvragen van ontheffing tot invordering van de direkte inkomstenbelasting (de 'grensarbeidersverklaring').

* Het recentelijk door het Hof van Justitie van de EG in de jurisprudentie uitgewerkte beginsel van gelijke behandeling van EG-ingezetenen op het terrein van de inkomstenbelastingen, zou een belangrijke rol kunnen spelen bij het zoeken naar oplossingen voor problemen waarmee de grensarbeiders op het gebied van de belastingwetgeving te kampen hebben. Het wachten is dan ook op uitspraken in proefprocessen die hierop voortbouwen.

* Per 1 januari 1991, heeft de Nederlandse belastingdienst de uitvoering van alle belastingzaken voor 'buitenlanders' in één organisatie-eenheid ondergebracht. Deze is daardoor ook aanzienlijk beter toegankelijk voor pendelaars en hun belangenorganisaties. Nagegaan zou moeten worden of een vergelijkbare concentratie en vereenvoudiging bij de Belgische en Duitse belastingdiensten bereikt zou kunnen worden.

* De Nederlandse belastingdienst schenkt tot op heden geen aandacht aan de voorlichting rondom pendelarbeid. Informatie hierover zou in ieder geval via de belastingtelefoon en de brochure-reeks van de douanedienst verstrekt moeten worden.

* De Nederlandse belastingdienst, Diensteenheid Buitenlanders, is op geen enkele wijze op de hoogte van organisatie of werkwijze van collega-belastingdiensten in België of Duitsland. Voorlichting of samenwerking kunnen hierdoor niet tot ontwikkeling komen. Het is derhalve wenselijk dat de mogelijkheden tot samenwerking e.d. tussen de belastingdiensten onderzocht worden.

* De grensoverschrijdende uitvoeringsprocedures van belastingdiensten en instanties voor sociale voorzieningen zouden op 'pendelvriendelijkheid' doorgelicht moeten worden door bilaterale projectteams, ondersteund door bijvoorbeeld externe organisatiedeskundigen. Ook zouden de Bureaus voor Belgische en Duitse Zaken daarvoor personele middelen toegewezen moeten krijgen.

De sociale verzekeringspositie van grensarbeiders wordt, zoals reeds eerder is aangegeven, voor een belangrijk deel geregeld in EEG-Verordening nr. 1408/71. Volgens deze Verordening zijn grensarbeiders voor wat betreft de verplichting van verzekering en premiebetaling onderworpen aan de wettelijke voorschriften van het land waar men werkt.

* Op nationaal niveau kunnen convergentie en coördinatie tot stand gebracht worden door bilaterale verdragen en wijzigingen (aanpassingen, aanvullingen) in de nationale wetgeving. De snelste weg om tot coördinatie te komen ligt echter bij het ontwikkelen van jurisprudentie van tot op Europees niveau uitgevochten procedures. De hieruit voortkomende uitspraken gelden immers voor alle EG-landen (gemeenschapsrecht) en staan boven de nationale wetgeving. De weg om tot een Europese uitspraak te komen is echter wel langdurig en moeizaam.

* Voormalige grensarbeiders kunnen, zoals gezegd, moeilijkheden ondervinden wanneer zij een uitkering wegens vervroegde uittreding of pensionering ontvangen, omdat deze uitkeringen niet onder de werking van de bovengenoemde EG-Verordening vallen. Het voorstel tot regulering van alle brugpensioenen dat de Commissie reeds in 1980 bij de Raad heeft 
ingediend is echter nog steeds niet aangenomen, omdat hiervoor de benodigde unanimiteit tot op heden heeft ontbroken. Vooruitlopend op een Europese regeling zouden Nederland en België een bilateraal verdrag met Duitsland kunnen afsluiten, overeenkomstig het door de Europese Commissie ontworpen voorstel.

* Gepensioneerde pendelaars en hun gezinsleden komen doorgaans niet meer in aanmerking voor medische voorzieningen in het voormalige werkland. Het zou wenselijk zijn dat wordt onderzocht in hoeverre gezinsleden van (gepensioneerde) pendelaars zonder voorafgaande toestemming van de ziektekostenverzekeraar, gebruik kunnen maken van de medische voorzieningen in het (voormalige) werkland.

* De opgebouwde rechten op aanvullend pensioen behoeven volgens wettelijk voorschrift in Duitsland bij ontslag in het algemeen alleen te worden meegegeven, indien de betrokkene tenminste 35 jaar oud is en 10 jaar aan de pensioenregeling heeft deelgenomen. In België is dat - zonder leeftijdsgrens - 5 jaar. De arbeidsmobiliteit vanuit deze landen zou bevorderd kunnen worden indien ook bij eerder vertrek (bijvoorbeeld bij elk ontslag na 1 jaar, zoals in Nederland) het opgebouwde pensioenrecht in stand zou worden gelaten.

* Teneinde de arbeidsmarktmobiliteit vanuit Duitsland naar Nederland en België en vanuit Nederland naar België te vergroten, dient ook informatie verzameld te worden over de knelpunten die bij deze (potentiële) pendelstromen kunnen optreden. Er zou, in samenwerking met de (regionale) vakorganisaties en analoog aan de door de Euregio TwenteWestmünsterland ingestelde Commissie 'Knelpunten grensarbeiders', een vergelijkbare werkgroep kunnen worden samengesteld, teneinde de problemen van deze pendelaars te inventariseren.

* Nagegaan zou moeten worden of de rol die de Bureaus voor Belgische- en Duitse Zaken thans al spelen bij de uitvoering van een aantal bestaande wetten en regelingen uitgebreid zou kunnen worden tot het gehele gebied van belastingen en sociale zekerheid. Deze zouden echter niet alleen als nationale service-bureaus voor pendelaars kunnen gaan werken doch zouden ook meer betrokken moeten worden bij (de voorbereiding van) wijzigingen in wetten en bepalingen.

* Nagegaan moet worden of op het terrein van de grensoverschrijdende rechtsbijstand maatregelen ondernomen zouden kunnen worden. Gedacht kan worden aan het ondersteunen van individuele pendelaars bij de rechtsgang, het stimuleren van proefprocessen, het toegankelijk maken c.q. ontsluiten van regelgeving en jurisprudentie, etcetera. Hierbij moet worden bedacht dat de ontwikkeling van het gemeenschapsrecht vooral plaats zal hebben door het voeren van (proef)processen tot op het hoogste juridische niveau. Gezien de rol van particuliere organisaties als de VEG (on-line databank, kwartaalblad, spreekuur, proefprocessen, e.d.) en vakorganisaties (onder andere de Dienst Grensarbeiders van de Belgische vakbond ACV) met spreekuren en juridische dienst, zouden deze daarin meer financiële, materiële of in ieder geval morele ondersteuning kunnen gebruiken. Daarnaast zou ook gedacht kunnen worden aan het toevoegen van een dienst Rechtbijstand aan bijvoorbeeld het Euroloket. Bij de Bureaus voor Rechtshulp en commerciële advocatenkantoren is de expertise voor grensoverschrijdende juridische conflicten op het terrein van rechtsgang, fiscaliteit en sociale zekerheid, overigens nagenoeg niet aanwezig.

\section{Financiën}

* Voor wat betreft de financiële problemen als gevolg van mogelijke schommelingen in wisselkoersen en de hoge banktarieven voor grensoverschrijdend betalingsverkeer, verwacht de Europese Commissie dat de totstandkoming van het Europees Monetair Systeem en de 
verwezenlijking van de Economische en Monetaire Unie zullen leiden tot een oplossing van deze problemen. Met name de vakorganisaties laten echter nog regelmatig een pleidooi horen voor het invoeren van een egalisatiefonds, van waaruit een speciale vergoeding door de overheid aan grensarbeiders kan worden verstrekt, ter compensatie van de nadelige gevolgen van wisselkoerswijzigingen. Recentelijk is een dergelijk egalisatiefonds tussen Frankrijk en België evenwel afgeschaft. Het afnemende belang van een dergelijk fonds als gevolg van de toegenomen stabiliteit van de wisselkoersverhoudingen is hiervoor een belangrijk motief geweest.

* Volgens een discussiestuk van de Europese Commissie (oktober 1990) zullen de verbeteringen van de in hoofdstuk 3 (3.3.) genoemde knelpunten vooral tot stand moeten komen door een sterkere financiële mededinging in de financiële sector te bewerkstelligen. Daarnaast is een systeemtechnische samenwerking tussen de commerciële- en centrale banken en andere financiële instellingen vereist. Naar de mening van een benaderde deskundige van de Nederlandsche Bank zal een goed en goedkoop grensoverschrijdend betalingsverkeer pas mogelijk zijn indien er een monetaire unie tot stand is gekomen.

Voor de ontwikkeling van het grensoverschrijdend betalingsverkeer kunnen als criteria gesteld worden dat de transacties snel en tegen redelijke kosten verricht moeten worden. Er moet sprake zijn van een gegarandeerde veiligheid en rechtszekerheid en van een betrouwbare controle daarop.

\subsection{NAAP EEN EUPEGIONALE ARBEIDSMARKT}

De vele eerder genoemde beleidssuggesties illustreren dat de ontwikkeling van een Euregionale arbeidsmarkt een proces is, waarbij een groot aantal aspecten van belang is. Bovendien spelen talrijke actoren op (Eu)regionaal, nationaal en communautair niveau een rol van betekenis.

Vanuit dit oogpunt is het goed om een onderscheid te maken tussen de beleidsinitiatieven die op korte termijn zouden kunnen worden ontplooid en de beleidsinitiatieven die op (middel)lange termijn ontwikkeld zouden kunnen worden.

Op de korte termijn zullen er ongetwijfeld, zowel binnen de Euregio Maas-Rijn, als daarbuiten op de diverse beleidsterreinen talloze initiatieven worden ontplooid door overheden, arbeidsvoorzieningsorganisaties, vakverenigingen, onderwijsinstellingen, belangenverenigingen van pendelaars e.d. Hoewel het aan de ene kant aantrekkelijk is dat een grote verscheidenheid aan organisaties een bijdrage levert aan de totstandkoming van een Euregionale arbeidsmarkt, kan dit tegelijkertijd ook nadelig zijn indien allerlei initiatieven elkaar overlappen of zonder enige coördinatie worden ontwikkeld.

Voor een meer gecoördineerde aanpak waarvan het geheel meer is dan de som der delen, zal in eerste instantie binnen de Euregio Maas-Rijn een vijftal beleidsinitiatieven nuttig kunnen zijn:

- het formuleren van een politieke visie op de mogelijkheden en wenselijkheden ten aanzien van de bestuurlijke samenwerking in de Euregio Maas-Rijn;

- het formuleren van een motiverend en inspirerend beleidskader, waarbinnen de verschillende meer concrete beleidsinitiatieven kunnen worden gepositioneerd;

- een aanzet geven tot de netwerkvorming binnen de Euregio, door het instellen van een 'Euregio Adviesraad' en thematische werkgroepen bestaande uit overheidsvertegenwoordigers, sociale partners en andere belanghebbenden (zie ook Buck, 1990);

- het voteren van regionale gelden ten behoeve van de beleidsterreinen die prioriteit hebben in het kader van de Euregionale samenwerking, in centrale Euregionale fondsen;

- het ontwikkelen van een actief informatiebeleid, waarmee de Euregio Maas-Rijn zich zowel binnen als buiten de Euregio kan profileren. 
Vanuit de Initiatiefgroep Euregioncongres zou een appèl gedaan kunnen worden in de richting van het Gouverneursoverleg om op bovengenoemde punten beleidsinitiatieven te ontplooien.

Vanzelfsprekend zou er op relatief korte termijn reeds een aanzet gegeven kunnen worden tot verschillende van de in de vorige paragrafen van dit hoofdstuk genoemde zeer concrete beleidsinitiatieven op het terrein van voorlichting en uitwisseling. Daarbij kan bijvoorbeeld worden gedacht aan:

- het ontwikkelen van een Euregio Statistiek. Deze statistiek kan ook een uiterst nuttige functie vervullen in de gewenste netwerkvorming;

- het verbeteren van de kwaliteit en de distributie van voorlichtingsmateriaal over de Euregio Maas-Rijn in het algemeen;

- het opzetten van een Euroloket voor de voorlichting over de sociale zekerheid en fiscaliteit in de Euregio Maas-Rijn;

- het uitwisselen van beleidsuitvoerend personeel e.d. tussen overheidsinstellingen en arbeidsvoorzieningsorganisaties door middel van stages of detacheringen.

De ontwikkeling in de richting van een Euregionale arbeidsmarkt zal, zoals hierboven reeds werd aangegeven, niet alleen afhankelijk zijn van de stappen die op dit terrein binnen de Euregio Maas-Rijn worden gezet. Ook allerlei ontwikkelingen in de richting van een Gemeenschappelijke Europese markt zijn vanzelfsprekend van groot belang. Daarnaast zullen vooral op het terrein van belastingen en de sociale zekerheid ook de bilaterale regelingen tussen lidstaten eveneens een belangrijke rol spelen, indien bepaalde ontwikkelingen op communautair niveau stagneren.

Hoewel de ontwikkelingen op communautair en nationaal niveau vanzelfsprekend van groot belang kunnen zijn voor de totstandkoming van een gemeenschappelijke arbeidsmarkt in de Euregio Maas-Rijn, moet ook worden beseft dat juist de samenwerking in de grensregio's een belangrijke stimulans kan geven aan de Europese samenwerking in het algemeen. De Euregio's vervullen daarmee een belangrijke katalysatorfunctie voor het Europese integratieproces. 


\section{LITERATUUR}

\section{PUBLIKATIES VAN BELANG VOOR NEDERLANDSE PENDEL:}

\section{Algemeen:}

CBA (1991), Internationale arbeidsbemiddeling. Onderzoek uitgevoerd door het Nederlands Economisch Instituut (NEI), in opdracht van het Centraal Bureau voor de Arbeidsvoorziening (CBA), Rijswijk.

ETIL (1990), Vraag en aanbod op de arbeidsmarkt in internationaal perspectief, ETIL onderzoekrapport, Maastricht.

ETIL (1991), Beroepskwalificaties in internationaal perspectief, ETIL-onderzoekrapport, Maastricht.

FNV (1991), FNV-Europees Programma, Amsterdam.

KPMG (1991), Klynveld Management Consultants. Trends en ontwikkelingen in Human Resource Management in Limburg, Eindhoven.

Nederlandse Belastingdienst/Directie Douane, diverse voorlichtingbrochures, Rotterdam.

SVR, Werken in het Buitenland, Voorlichtingsbrochure Sociale Verzekeringsraad, Amsterdam.

VSV (1991), De kleine gids voor de Nederlandse sociale zekerheid, Kluwer/VSV, Deventer/ Amsterdam.

\section{Naar België:}

BBZ (1991), Vergelijkend Overzicht van de Nederlandse en de Belgische sociale verzekerings wetgevingen voor loontrekkenden, per 1 januari 1991, Stichting Bureau voor Belgische Zaken.

BBZ (1991), De Sociale Verzekering van (buitenlandse) werknemers in België, Voorlichtingsstencils, Stichting Bureau voor Belgische Zaken.

Benelux (1991), Voorlichtingsrapport voor Nederlandse grensarbeiders in België, secretariaatgeneraal Benelux, Brussel.

\section{Naar Duitsland:}

BDZ (1989), Jaarverslag 1989, Bureau voor Duitse Zaken, Nijmegen.

BDZ (1991), Pensioenen en renten. Overzicht van de aanspraken op Nederlandse en Duitse pensioenen (uitkeringen) en renten uit de wettelijke sociale verzekeringen, met toepassing van de daarvoor geldende EEG-bepalingen. Bureau voor Duitse Zaken, Nijmegen. 
BDZ (1991), De sociale verzekering van in Nederland wonende werknemers die in de Bondsrepubliek Duitsland werkzaam zijn, Bureau voor Duitse Zaken, Nijmegen.

Euregio (1989), Knelpuntennota Grensarbeiders, Euregio Twente-Westfalen, Enschede/Gronau.

Euregio (1989), De Duitse en Nederlandse Sociale Verzekeringen. Een vergelijkend overzicht. Samengesteld door L. Opheikens en H. Neumeister, Enschede/Gronau.

Ministerie van Sociale Zaken en Werkgelegenheid (1991), Grensarbeiders en sociale zekerheid in de betrekkingen tussen Nederland en de Bondsrepubliek Duitsland. Een reaktie op de Knelpuntennota Grensarbeiders van het Samenwerkingsverband te Enschede/Gronau. Ministerie van Sociale Zaken en Werkgelegenheid, Hoofdafdeling Verdragen, Den Haag.

VEG, Pendel-Info, Kwartaalblad Vereniging Europese Grenslandbewoners, Landgraaf.

VEG (1990), Einige Anmerkungen aus der Sicht der Deutsch/Niederländischen Grenzgängern.

VEG (1991), Wonen in Nederland en werken in Duitsland. Richtlijnen voor grensarbeiders. Informatieboekje Vereniging van Europese Grenslandbewoners, Kerkrade.

\section{PUBLIKATIES VAN BELANG VOOR BELGISCHE PENDEL:}

\section{Algemeen:}

Goethals (1990), Grensarbeid in de Euregio Maas-Rijnland en Saar-Lor-Lux, onderzoekverslag, Hoger Instituut voor de Arbeid, Leuven.

\section{Naar Duitsland:}

ACV (1991), Informatiebrochure voor (Belgische) grensarbeiders in Duitsland, Algemeen Christelijk Vakverbond, Dienst Grensarbeiders, Eupen.

\section{Naar Nederland:}

ACV (1989), Diverse brochures en pamfletten voor Belgische grensarbeiders werkzaam in Nederland. Algemeen Christelijk Vakverbond, Dienst Grensarbeiders, Hasselt. In het bijzonder: Verslag debatavond 10.4.1987, Hengelhoef.

VDAB (1990), Verleg uw grenzen. Arbeidsbemiddeling aan de grenzen tussen beide Limburgen. Verslag van seminarie te Tongeren, 29 en 30 November 1990, Vlaamse Dienst voor de Arbeidsbemiddeling.

BENELUX (1991), Voorlichtingsrapport voor Belgische grensarbeiders in Nederland, secretariaatgeneraal Benelux. 


\section{PUBLIKATIES VAN BELANG VOOR DUITSE PENDEL:}

geen publikaties aangetroffen

\section{PUBLIKATIES OVER SAMENWERKING EN ONTWIKKELING IN DE EUREGIO MAAS-RIJN EN ANDERE EUREGIO'S}

\section{Algemeen}

WVEG (1991), Informatiebrochure over Linkage Assistance and Cooperation for the European border regions (LACE), Werkgemeenschap van Europese Grensgebieden, Gronau.

\section{Economische ontwikkeling Euregio Maas-Rijn}

Buck (1990), Waar liggen de grenzen? Limburg 25 jaar verder. Rapport van de Commssie 'Toekomst Limburg'. Rapportage door Buck Consultants International, Nijmegen.

Hans-Böckler-Stiftung (1986), Ontwikkeling van de economische struktuur in de Euregio MaasRijn, Samenvatting van een onderzoek in opdracht van de Interregionale Vakbondsraad in de Euregio Maas-Rijn, Aken.

ILS (1982), Institut für Landes- und Stadtentwicklungsforschung des Landes Nordrhein-Westfalen, Strukturanalyse für die Euregio Maas-Rhein. Grundlagen für das Grenzüberschreitende Aktionsprogramm' für die Euregio Maas-Rhein, Dortmund.

Maks, J., e.a. (1987), De economische gevolgen van het Europese integratiebeleid voor de provincie Limburg: een eerste empirische studie, Maastricht.

Zinn, K.G. (1985), Entwicklung der Wirtschaftsstruktur der Euregio Maas-Rhein. Analyse von Beschäftigung und Produktion anhand von Regional-, Struktur- und Standortfaktoren, Aachen.

\section{Opleidings- en scholingsprojecten in EMR en andere Euregio's}

Arbeidsbureau Nijmegen (1991), Scholingsproject tot internationaal management and marketing assistent, Stichting Beroepsgerichte opleidingen, in samenwerking met het Arbeidsbureau Nijmegen.

COA (1991), Inventarisatie van scholingsprojecten langs de Nederlandse grens, COA-Limburg, 1991, (intern verslag).

Euregio Maas-Rhein, Berufsbildungsexperiment (EVE-project). Endbericht über die Vorbereitungs phase 1985, ECWS.

Euregio Twente/Westmünsterland (1991), Beroepsopleidingen en Arbeidsmarkt. Rapport van de Stichting Grensoverschrijdende Beroepsopleiding. Gronau/Enschede. 
Hochschuldidaktisches Zentrum Aachen (1991), Partizipation, Innovation, Technikgestaltung. Arbeitnehmer Aus- und Weiterbildungsbüro für die Euregio Maas/Rhein, Ein Comett IIprojekt, Aachen.

Regio Rhein-Waal (1991), Schule, Ausbildung und Berufsperspektiven in der Grenzeregion-Am Beispiel der Regio Rhein-Waal. Symposium verslag 15/16 mei 1991, Emmerich.

\section{Andere samenwerkingsvormen in grensregio's}

Euregio Maas-Rijn, Onderzoeksinstellingen in de Euregio Maas-Rijn.

Euregio Inform, knipselkrant Euregio Twente-Westfalen.

Interregionale vakbondsraad, Problematieken van grensarbeiders. Rapport van de Commissie Grensarbeiders Euregio Maas-Rijn.

Verslag en resoluties van bijeenkomst Vakbondseuregio Maas-Rijn, 12 en 13 april 1991, Tongeren.

\section{OVERICE UITERATUUR}

ABP (1991), Aanvullende pensioenen en een verenigd Europa, Interne notitie CS/SBO/SV/ HVA, Algemeen Burgerlijk Pensioenfonds, Heerlen.

BEUC (1988), Transfer of Money within the EEC, Europees Bureau van Consumenten verenigingen-BEUC 76/88.

BSO/Artificial Intelligence (1991), Dienstencentra in het Buitenland. Verkennend onderzoek naar ervaringen met dienstencentra met geïntegreerde loketfuncties in Zweden, Italië, GrootBrittannië, lerland, Duitsland, België en Denemarken. Door dr. M.A.Nieuwenhuis, Utrecht.

Europese Commissie (1990), Het verrichten van betalingen op de interne markt. Discussiestuk. $\operatorname{COM}(90) 447$ def., Brussel.

Europese Commissie (1990), Levens- en arbeidsvoorwaarden van de burgers uit de Gemeenschap die in de grensgebieden wonen, met name de grensarbeiders. Mededeling van de Commissie.

Economie et Emploi: perspectives pour Liege. Resumé du colloque, Palais des Congrès de Liège, les 27 et 28 avril 1990.

FEM (1989), Halen de grensarbeiders 1992? in: Financieel-Economisch Magazine (18), 26 augustus 1989, pp.36-37.

Finanz Min. (1990), Bericht über die Behandlung verschiedener Gruppen von Grenzgängern und anderen Grenzlandbewohnern bei der Einkommensteuer/Lohnsteuer. Finanzamt, Bonn.

Goethals (1990), Grensarbeid in de Euregio Maas-Rijnland en Saar-Lor-Lux, onderzoeksverslag, Hoger instituut voor de Arbeid, Leuven. 
Grensregio Benelux Middengebied (1990), Operationeel Interreg-programma 1990-1993. Programma voor grensoverschrijdende samenwerking in het Benelux Middengebied.

Grensregio Rijn-Maas Noord (1986), Grensoverschrijdend Aktieprogramma voor de Grensregio Rijn-Maas Noord.

Grensregio Rijn-Maas Noord (1991), Grensoverschrijdend Uitvoeringsprogrammma. Samengesteld door Bureau BRO, Vught.

Grooten, M.H.P. (1991), De mogelijkheden en onmogelijkheden van EG-technologieprogramma's, in: Onderwijs in Europees perspectief. Reader studiemiddag op 3 mei 1991. Uitgave Stichting Technologie Centrum Limburg, Heerlen.

Hofstede, G.H. (1980), Culture's Consequences, International Differences in Work-Related Values, Sage Beverly-Hills.

IGA (1991), Projectvoorstel Intensieve Grensoverschrijdende Activiteiten, Y. Sterkendries en M.A.F. Soeren.

PRVL (1991), Provinciale Raad voor de volksgezondheid Limburg, Gezondheidszorg en de Limburgse grens, In: Volksgezondheidsverkenningen, juni 1991/l, Maastricht.

Schreuder, H. (1990), Strategische allianties: een inleidend overzicht, in: De strategische alliantie, alternatief voor fusie c.q. overname?, Tilburg.

Soeters, J. (1991), Het management van Euregionale netwerken, in: Binnenlands Bestuur (nog te verschijnen).

STPL (1991), Projectvoorstel Euregionale koppeling arbeidsbureaus. Stichting Telematica Platform Limburg. (Intern)

Tweede Kamer der Staten-Generaal (1990-1991), Verslag van de Staatssecretaris van Buitenlandse Zaken betreffende de Interne Markt Raad, dd. 18/19 juni 1991. Kenmerk: 21 501-01, nr. 27

Vlist, J.A. van der (1988), Werken langs de grens. Proefschrift Erasmus Universiteit Rotterdam. 


\section{BIJLAGE I: PERSONEN/INSTANTIES WAARMEE GESPREKKEN ZIJN GEVOERD}

\section{HOOFDLUNEN ONDERZOEK}

- mevr. Reggers, dhr. Konings, VDAB Tongeren

- M. Semer, FOREM Luik

- dhr. Meens, Arbeitsamt Aachen

- W. Friedrichs, J. Schipper, FNV Heerlen

- J. Maatjens, A. Janssen, J. Wouters, provincie Limburg/Euregio-bureau

- M. Depondt, M. Buskens, COA Limburg, Maastricht

- M. de Raeve, secretaris Grenspendelcommssie ACV Hasselt

- mevr. Zinn, dhr. Boltersdorf, Euregionaal Bureau Aken

\section{KWANTITATIEF/KWALITATIEFINZICHT IN PENDELSTROMEN}

- A. Crijns, KPMG Klynveld Management Consultants

- P. Hanraets, ETIL (telefonisch)

- H. Heinrichs, Landesamt Datenverarbeitung und Statistik Nord Rhein Westfalen (telefonisch)

- H. Cruysen, Eurostat, Luxemburg

\section{KNELPUNTEN (ALGEMEEN) EN INFRASTRUCTUUR UAN INFORMATIEVOORZIENING/VOORLICHTING}

M. Soeren, Arbeidsbureau Westelijke Mijnstreek

R. Le Bron de Vexela, personeelsconsulent AZM

dhr. Reinaerts, hoofd personeels- en salarisadministratie AZM

N. Bauer, Vereniging Europese Grenslandbewoners (VEG), pendelaar (Nederland - Duitsland)

dhr. Velraad, Europees Informatiecentrum Kerkrade

dhr. Meenk, hoofd personeelszaken VOLVO

L. Bentlage, Deutsche Gewerkschafts Bund (DGB) Aachen

dhr. Bielfeld, hoofd Personeelszaken Talbot Aken

T. Looyschelder, Bureau voor Duitse Zaken, Nijmegen

E. Walter, Bureau voor Belgische Zaken, Breda

J. Beckers, KNP Hoofd Personeelszaken Servicegroep

J. Wenderoth, Personalreferent Philips Glasfabrik Aken

- Groepsgesprek met Nederlandse werknemers Talbot (Aken)

- Groepsgesprek met Belgische CFO-leden Academisch Ziekenhuis Maastricht

- Groepsgesprek met Belgische en Nederlandse werknemers Philips Glasfabrik Aken

- mevr. S. Gorgels, LICE '92, Kamer van Koophandel, Heerlen. 


\section{KNELPUNTEN (SPECIFIEK)}

- dhr. Steevens, coördinator belastingformulierinvullers voor FNV

- A. v.d. Broek, jurist FNV Limburg

- R. Kuhlmann, Hoofd Consultancy en System Development, Teelen B.V., Enschede

- dhr. Malis, IHK zu Aachen, Aken

- A. v.d. Mey, arbeidsjurist RL ihb. mbt. grensoverschrijdend verkeer van rechtspersonen in EG

- I. v.d. Steen, Afdeling Verdragen, Ministerie van Sociale Zaken en Werkgelegenheid

\section{GRENSOVERSCHRIDENDE SAMENWERKINGSPROJECTEN}

- F. Ramm, Geschäftsführer Berufsbildung, IHK zu Aachen

- H. Deupmann, coördinator Arbeidsmarkt en Beroepsopleidingen Euregio Twente/Westfalen

- dhr. Doon, dhr. Wolf, organisatie Euregionale beroepenmanifestatie MECC-Job'91

- dhr. Van Boven, GAB Bergen op Zoom (telefonisch) 


\section{Thema Arbeidsmarkt (3 oktober 1991):}

- dhr. P. Elferink (Stichting Werkgelegenheid en Arbeidsmarkt Limburg SWAL)

- dhr. F. Soeren (Arbeidsbureau Sittard)

- dhr. P. Janssen (Gemeente Maastricht)

- drs. J.J. Zwartjes (Economisch Technologisch Instituut Limburg, ETIL)

\section{Thema Onderwijs en Opleiding (10 oktober 1991):}

- drs. F. Boss (Stichting Technologie Centrum Limburg Heerlen)

- drs. H. Broekhuyse (lid Initiatiefgroep Euregiocongres)

- dhr. X. Christiaens (provinciale onderwijsinspectie, Provincie Belgisch Limburg)

- dr. H. Katterbach (Hand Werks Kammer Aachen)

- dhr. A.F. Reinierkens (Centrum Vakopleiding Volwassenen, Heerlen)

- dhr. J. v.d. Steyn (Limburgs Centrum voor Bedrijfsopleidingen, LCB)

- dhr. P. Willems (Limburgs Instituut voor Onderwijsonderzoek en -Oriëntatie, LIOO, Hasselt)

- prof. L. Soete (MERIT, Maastricht)

- Mr. Th. van der Voort (Centrum Vakopleiding Volwassenen, Maastricht)

- prof. H.C. de Wolf (Open Universiteit, Heerlen)

- dhr. F. Wolf (Provincie Nederlands Limburg)

\section{Thema Sociale Zekerheid en Pensioenen (21 oktober 1991):}

- dhr. J. van Aalst (Algemeen Burgerlijk Pensioenfonds, Heerlen)

- dhr. J. van Gils (Bureau voor Belgische Zaken, Breda)

- mevr. mr. E. van Hilten (GAK Amsterdam)

- dhr. J.W. Janssen (Bureau voor Duitse Zaken, Nijmegen)

- dhr. M. de Raeve (ACV - Dienst grensarbeiders, Hasselt)

\section{Thema Belastingen en Betalingen (22 oktober 1991):}

- dhr. N. Bauer (Vereniging Europese Grenslandbewoners, VEG)

- dhr. P. Bellefroid (Nationaal Christelijke Middenstandsvereniging, Hasselt)

- dhr. C. Hooy (NMB Postbank, Eindhoven)

- prof. W. Kaefer (Technische Hochschule Aachen, tevens adviseur VEG)

- dhr. J. Ketelsen (Europees Commissie, Divisie Arbeidsmarktpolitiek, Brussel)

- dhr. G. Koolen (NMB Postbank, Amsterdam)

- drs. J. Monsewije (Gemeente Kerkrade, Dienst Financiën)

- prof. R. Niessen (Rijksuniversiteit Limburg - Fiscaal Recht)

- dhr. M. de Raeve (ACV -Dienst grensarbeiders, Hasselt)

- dhr. F. Stevens (NMB Postbank, Maastricht)

- dhr. F. Suvrijn (Belastingdienst BPOB, Brunssum)

dr. K. Verhoef (NMB Postbank, Amsterdam) 
$\ldots$ 
DE EUREGIONALE ARBEIDSMARKT: VAN FICTIE NAAR WERKELIJKHEID

- Knelpunten, initiatieven en beleidsmogelijkheden.

ROA-R-1991/10

J.W. van Dam

A. de Grip

\section{RESEARCHCENTRUM VOOR ONDERWIJS EN ARBEIDSMARKT}

Faculteit der Economische Wetenschappen

Rijksuniversiteit Limburg

Maastricht, november 1991 

CIP-GEGEVENS KONIJKLIJKE BIBLIOTHEEK, DEN HAAG

Dam, J.W. van

De Euregionale arbeidsmarkt: van fictie naar werkelijkheid: knelpunten, initiatieven en beleidsmogelijkheden / J.W. van Dam, A. de Grip. -Maastricht : Researchcentrum voor Onderwijs en Arbeidsmarkt. Faculteit der Economische Wetenschappen, Rijksuniversiteit Limburg. -(Rapport / Researchcentrum voor Onderwijs en Arbeidsmarkt, ISSN 0922-8098; 1991/10

Met lit. opg.

ISBN 90-5321-068-7

Trefw.: arbeidsmarkt; Euregio Maas-Rijn 



\section{INHOUDSOPGAVE}

Bladzijde

VERANTWOORDING

i

SAMENVATTING

iii

ZUSAMMENFASSUNG

$x i$

SYNTHESE

xix

1. INLEIDING

2. DE ARBEIDSMARKT IN DE EUREGIO MAAS-RIJN

2.1. Ligging en bevolking

2.2. Economische structuur en werkgelegenheid

2.3. De pendelstromen in de Euregio Maas-Rijn

3. KNELPUNTEN RONDOM GRENSARBEID

3.1. Inleiding

3.2. Knelpunten in de dataverzameling en informatievoorziening 8

3.3. Knelpunten naar themagebied 10

$\begin{array}{ll}\text { 3.3.1. Arbeidsmarkt } & 10\end{array}$

$\begin{array}{ll}\text { 3.3.2. Onderwijs en scholing } & 12\end{array}$

$\begin{array}{ll}\text { 3.3.3. Fiscus en financiën } & 13\end{array}$

3.3.4. Sociale zekerheid en pensioenen 16

Schema 1: Overzicht van de belangrijkste knelpunten per doelgroep en thema 22

4. HUIDIGE ACTIVITEITEN EN INITIATIEVEN 24

4.1. Inleiding 24

4.2. Overzicht van initiatieven per thema 24

4.2.1. Arbeidsmarkt 24

4.2.2. Onderwijs en scholing 25

4.2.3. Fiscus en financiën 26

4.2.4. Sociale zekerheid en pensioenen $\quad 28$

4.3. Beschrijving van enkele initiatieven en samenwerkingsprojecten 29

4.3.1. Voorlichting met betrekking tot pendelproblematiek 29

$\begin{array}{ll}\text { 4.3.2. Scholingsprojecten } & 30\end{array}$

4.4. Overzicht van activiteiten 31

Schema 2: Overzicht van de belangrijkste activiteiten en initiatieven per thema 32 
5.1. Inleiding 35

5.2. Algemene aandachtspunten voor de beleidsontwikkeling 35

5.3. Beleidssuggesties 39

5.3.1. Algemene beleidssuggesties $\quad 39$

5.3.2. Arbeidsmarkt 44

5.3.3. Onderwijs en scholing 45

5.3.4. Fiscus en financiën; sociale zekerheid en pensioenen 47

5.4. Naar een Euregionale arbeidsmarkt 50

LITERATUUR 


\section{VERANTWOORDING}

Ter ondersteuning van het congres 'Euregio: Fictie of werkelijkheid?' over de arbeidsmobiliteit in de Euregio Maas-Rijn op 28 november 1991 in het MECC te Maastricht, is door het Provinciaal Bestuur van Nederlands Limburg, op instigatie van de Initiatiefgroep Euregionale Manifestatie, aan het Researchcentrum voor Onderwijs en Arbeidsmarkt (ROA) gevraagd een studie uit te voeren naar de knelpunten die zich voordoen bij de Euregionale arbeidsmobiliteit. Het onderzoek werd uitgevoerd door drs. J.W. van Dam, onder leiding van dr. A. de Grip. Dr. R.K.W. van der Velden heeft met name in de beginfase een ondersteunende rol vervuld in de begeleiding van het onderzoek.

Voor de inhoudelijke begeleiding van het onderzoek is op verzoek van de opdrachtgever een begeleidingscommissie samengesteld onder voorzitterschap van dr. L.L.M. Frederix, voorzitter van het Regionaal Bestuur voor de Arbeidsvoorziening Zuid-Limburg. De begeleidingscommissie bestond verder uit de volgende leden:

- drs. N.J.P.M. Bos: secretaris Initiatiefgroep Euregionale Manifestatie;

- drs. F.J.M. Boss, Provincie Nederlands Limburg;

- drs. H.J.M. Broekhuyse, lid Initiatiefgroep Euregionale Manifestatie;

- dhr. W. Friedrichs, Voorzitter F.N.V. Limburg, lid initiatiefgroep Euregionale Manifestatie;

- dhr. V. Konings, Directeur VDAB Tongeren;

- dhr. R. Loop, FOREM Brussel;

- dhr. R. Nouwen, Voorzitter Provinciaal Christelijk Vakverbond van Limburg, Hasselt;

- dhr. F. Poelmann, Arbeitsamt Aachen;

- mevr. M. Reggers, VDAB Tongeren;

- drs. H.J.M. Rutten, lid Initiatiefgroep Euregionale Manifestatie;

- dhr. M. Semer, FOREM Luik;

- dhr. M.A.F. Soeren, Arbeidsbureau Sittard;

- dr. J.J. Soeters, Provincie Nederlands Limburg, coördinator Euregionale Manifestatie;

- mevr. Y. Sterkendries, VDAB Brussel.

Naast de leden van deze begeleidingscommissie is dank verschuldigd aan de heren $N$. Bauer van de Vereniging van Europese Grenslandbewoners (VEG) en M. de Raeve, secretaris van de Dienst Grensarbeiders van de ACV te Hasselt, voor hun uitvoerige becommentariëring van concept-teksten van dit rapport.

In de eindfase van het onderzoek is, eveneens ter voorbereiding op het Euregionale Congres van 28 november 1991 in het MECC, onder leiding van dr. L.L.M. Frederix, een aantal groepsgesprekken gevoerd met deskundigen op de vier op het congres onderscheiden beleidsterreinen. Enkele belangrijkste uitkomsten van deze gesprekken zijn in dit rapport opgenomen. 

Samel 

Het magische 'Europa zonder binnengrenzen' zal ongetwijfeld in eerste instantie vooral door de bewoners van de grensstreken aan den lijve ondervonden gaan worden of, zoals de Europese Commissie (1990) zelf aangeeft: 'het is duidelijk dat de grensarbeiders bijzonder getroffen worden door de vertraging die bij de verwezenlijking van de doelstellingen van de Europese Gemeenschap kan optreden'. De problemen die zich ondanks alle voornemens voor de Europese integratie, nog dagelijks in de praktijk voordoen, komen dan ook zeer sterk naar voren in één van de meest complexe Euregio's van Europa. In de Euregio Maas-Rijn komen niet alleen drie nationaliteiten bij elkaar, maar ook drie verschillende taal- en cultuurgebieden.

In de Euregio Maas-Rijn bewegen zich dagelijks naar schatting 20.000 personen over een landsgrens om hun werk te verrichten. Deze pendelbeweging is voornamelijk oostwaarts gericht: er werken relatief veel Belgen in Nederland of Duitsland en veel Nederlanders in de Duitse grensstreken.

Deze studie is verricht in het kader van het congres 'Euregio: Fictie of werkelijkheid' over de arbeidsmarktmobiliteit in de Euregio Maas-Rijn, op 28 november 1991 te Maastricht. In het voorliggende rapport wordt ingegaan op een aantal knelpunten die het functioneren van een Euregionale arbeidsmarkt zonder binnengrenzen nog in de weg staat. Tevens wordt een aanzet gegeven tot het formuleren van beleidsinitiatieven die de totstandkoming van een dergelijke Euregionale arbeidsmarkt dichterbij zouden kunnen brengen. In het rapport wordt aandacht geschonken aan de volgende vier thema's: Arbeidsmarkt; Onderwijs en scholing; Fiscus en financiën; en Sociale Zekerheid en pensioenen. Per thema wordt een aantal van de belangrijkste knelpunten en reeds ontwikkelde initiatieven kort weergegeven. Daarna komen enkele mogelijkheden voor nieuw beleid aan de orde. Voor een globaal overzicht van knelpunten en de reeds bestaande activiteiten en beleidsinitiatieven wordt ook verwezen naar respectievelijk de schema's 1 en 2 uit het onderzoekrapport.

\section{H. AREEIDSMARKT}

Tot op heden komt het grootste aandeel van de internationale arbeidsmobiliteit tot stand door acties van individuele werkgevers of werknemers. De diverse overheidsdiensten en arbeidsvoorzieningsorganisaties spelen bij het bevorderen van een vrij verkeer van werknemers vooralsnog een bescheiden rol. De grensoverschrijdende bemiddeling door arbeidsvoorzieningsorganisaties vindt veelal plaats door persoonlijke contacten van bemiddelaars en door de uitwisseling van informatie over vacatures. Deze uitwisseling blijkt op enkele plaatsen redelijk succesvol te zijn. De geautomatiseerde vacature-uitwisseling tussen arbeidsbureaus verloopt daarentegen nog steeds stroef, onder meer vanwege de uiteenlopende nationale stelsels van vacature-registratie. Bovendien lijkt de 'trefkans' voor een geslaagde bemiddeling beperkt te zijn, indien er bij werkgevers en (potentiële) pendelaars onvoldoende inzicht is in de vraag-aanbod verhoudingen aan de andere zijde van de grens. Knelpunten doen zich hierbij zowel voor vanwege het ontbreken van datamateriaal als vanwege het ontbreken van een laag-drempelige geïntegreerde voorlichting. Met name het midden- en kleinbedrijf is vaak ook onbekend met de waarde van de diploma's in de buurlanden. Recentelijk zijn er op het terrein van de voorlichting belangrijke initiatieven genomen, zoals het geplande 'Euroloket' van de arbeidsvoorzieningsorganisaties.

Enkele beleidsaanbevelingen:

* Een inventariserend onderzoek naar de informatiebehoefte bij de verschillende doelgroepen in de Euregio en de mogelijkheden om in deze informatiebehoefte te kunnen voorzien is gewenst.

* De bij de Euregio betrokken overheden zouden zich moeten uitspreken voor een uniform, overkoepelend en geïntegreerd voorlichtingsbeleid, ten einde een verbrokkeling van initiatieven vanuit gescheiden circuits te voorkomen. 

* Het bureau van de Euregio Maas-Rijn zou een stimulerende en initiërende rol kunnen spelen bij het vergroten van de kennis (doelgroep, bereik, kosten) bij lokale media en bedrijven over de verschillende wervingsmogelijkheden, -kanalen en -procedures in de Euregio.

* In de informatievoorziening en beeldvorming naar personen en bedrijven toe, dienen niet alleen de momenteel bij grensarbeid ondervonden knelpunten benadrukt te worden, maar vooral ook de positieve aspecten van de schaalvergroting van de (Eu)regionale arbeidsmarkt.

* De diverse overheden of (semi-)overheidsinstellingen binnen de Euregio zouden een voortrekkersrol op de arbeidsmarkt kunnen vervullen, waarbij bovendien wederzijdse kennis en begrip van de 'beleidscultuur' in de buurlanden kan worden ingepast. Met name de uitwisseling van beleidsuitvoerend personeel, e.d., middels stages c.q. detacheringen zou daarbij een belangrijke plaats kunnen innemen.

\section{ONDERWUS EN SCHOLWG}

$\mathrm{Er}$ is nog een groot aantal factoren waardoor het volgen van een opleiding over de grens wordt bemoeilijkt. Een tweetal knelpunten staat daarbij centraal:

- er is geen afstemming van de opleiding op de behoeften aan de andere kant van de grens;

- men heeft geen directe toegang tot de onderwijsstelsels in de buurlanden.

Bovendien ontbreekt het nog aan een toegankelijk overzicht van de vraag naar en het aanbod van opleidings- en scholingsmogelijkheden en de daarvoor geldende vooropleidingseisen. Ook doet zich een omvangrijk probleem voor op het gebied van de erkenning van diploma's, al bestaat er thans wel een algemene Richtlijn voor de erkenning van hogere onderwijsdiploma's en wordt er gewerkt aan een Richtlijn voor diploma's en certificaten op middelbaar niveau. Door de Europese Commissie zijn reeds tal van Europese actieprogramma's geïnitieerd op het terrein van onderwijs en scholing.

In de Euregio Maas-Rijn is momenteel sprake van een beperkt aantal grensoverschrijdende scholingsprojecten. Deze zijn voornamelijk op initiatief van opleidingsinstanties en brancheorganisaties tot stand gekomen. Opvallend is dat, ondanks mogelijke taalproblemen, verreweg de meeste projecten zich voordoen in de Nederlands-Duitse grensstreek. De projecten in het algemeen voortgezet onderwijs lijken zich vooralsnog met name te richten op kennismaking en uitwisseling. Bij het beroepsonderwijs lijkt er daarentegen vaker sprake te zijn van gezamenlijke scholingsprojecten, op het gebied van onder meer de gezondheidszorg, het economisch- en administratief onderwijs, de procestechnologie en computersimulatie, metaalbewerking en het internationale transport.

Enkele beleidsaanbevelingen:

* Initiatieven gericht op de integratie van onderwijsprogramma's zijn van groot belang.

* Er zou een inventarisatie gemaakt moeten worden van de formele-, organisatorische en financiële belemmeringen die een dergelijke integratie in de weg staan.

* De subsidieverstrekkers voor scholingsprojecten in de Euregio Maas-Rijn (overheden, scholingsfondsen), zouden een gezamenlijk opleidingsbeleidsplan kunnen initiëren, met gemeenschappelijke subsidievoorwaarden.

* Een 'Euregionaal actieplan regio-talen' lijkt gewenst.

* Nagegaan moet worden in hoeverre er in de Euregio Maas-Rijn behoefte is aan een instelling voor het initiëren of coördineren van grensoverschrijdende beroepsopleidingen en vakcursussen. Door samenwerking en afstemming op het gebied van opleidingen, scholing en examinering dient er langzamerhand een gelijkschakeling van opleidingskwalificaties van vaklieden te ontstaan waardoor de mobiliteit van werknemers kan toe nemen. 


\section{FISCUS EN FINANCIEN}

De problemen die zich voordoen op het gebied van belastingen en financiën als ook op het terrein van de sociale zekerheid zijn te onderscheiden in een viertal groepen van knelpunten:

1. Problemen als gevolg van conflicterende stelsels van wet- en regelgeving;

2. Problemen als gevolg van onjuiste of onvoldoende informatie bij pendelaars over de relevante wet- en regelgeving;

3. Problemen als gevolg van elkaar overlappende of herhalende uitvoeringsprocedures;

4. Problemen als gevolg van ondoorzichtige beroepsmogelijkheden of het ontbreken van adequate juridische bijstand;

Voor pendelaars tussen België en Nederland doen zich op het terrein van de persoonlijke inkomstenbelasting weinig problemen voor als gevolg van een adequaat bilateraal belastingverdrag. Veel meer problemen ondervinden de Belgische en Nederlandse pendelaars die werken in Duitsland. Deze problemen hebben betrekking op ongunstige tariefindelingen en het ontbreken van mogelijkheden voor de aftrekbaarheid van diverse kostenposten. Hierdoor worden vooral zelfstandigen, alleenstaande ouders en part-time pendelaars onevenredig zwaar belast. Er lijkt voorlopig geen zicht te zijn op een verbetering van deze situatie door bijvoorbeeld aanpassingen van de nationale wet- en regelgeving op basis van een Europese richtlijn of door bilaterale verdragen.

De informatievoorziening rondom de loonbelastingproblemen van pendelaars is nog steeds zeer ontoereikend. Enkele particuliere organisaties (Belgische vakbonden, een vereniging van grenslandbewoners) onderhouden een breed assortiment van voorlichtingsmiddelen die veelal alleen bestemd zijn voor leden/pendelaars. Met name de kleinere bedrijven en zelfstandigen worden hierdoor niet bereikt. De belastingdiensten zelf zijn op dit terrein nog nauwelijks actief. Bij de belasting-inning zijn naast de belastingdienst ook de werkgevers en/of uitkerende instanties als bedrijfsverenigingen of pensioenfondsen betrokken. Er blijkt in de uitvoeringpraktijk echter nauwelijks sprake te zijn van samenwerking of afstemming tussen de diverse betrokkenen. Ook lijken de mogelijkheden tot grensoverschrijdende beroepsprocedures en een eventuele rechtsgang voor individuele pendelaars in de praktijk nauwelijks haalbaar te zijn.

Enkele beleidsaanbevelingen:

* Met betrekking tot de uitvoering van de bilaterale belastingverdragen tussen Nederland, België en Duitsland zou voor de pendelaars een aanzienlijke verbetering bewerkstelligd kunnen worden, indien de werkgever en uitkerende instanties verantwoordelijk worden gesteld voor het aanvragen van ontheffing tot invordering van de directe inkomstenbelasting (de 'grensarbeidersverklaring').

* Teneinde de arbeidsmarktmobiliteit vanuit Duitsland naar Nederland en België en vanuit Nederland naar België te vergroten, dient ook informatie verzameld te worden over de knelpunten die bij deze (potentiële) pendelstromen kunnen optreden.

* Nagegaan moet worden of op het terrein van de grensoverschrijdende rechtsbijstand maatregelen ondernomen zouden kunnen worden. Gedacht kan worden aan het ondersteunen van individuele pendelaars bij de rechtsgang, het stimuleren van proefprocessen, het toegankelijk maken c.q. ontsluiten van regelgeving en jurisprudentie, etc.

* Wellicht dat er in België en de Bondsrepubliek Duitsland mogelijkheden zijn voor een overzichtelijker organisatie van de belastingdienst voor pendelaars.

* De grensoverschrijdende uitvoeringsprocedures zouden op 'pendel-vriendelijkheid' doorgelicht moeten worden door bilaterale projectteams. De Bureaus voor Belgische- en Duitse Zaken zouden daarvoor personele middelen toegewezen moeten krijgen. 

Hoewel er op basis van een Europese Richtlijn enige coördinatie tussen de nationale stelsels van sociale zekerheid tot stand is gebracht, blijken er in de dagelijkse praktijk voor individuele pendelaars nog vooral problemen op te treden op het gebied van de ziektekosten, de arbeidsongeschiktheid, en de ouderdomsvoorzieningen en pensioenen. Deze problemen worden deels veroorzaakt door de principeel verschillende uitgangspunten die aan de nationale zekerheidsstelsels ten grondslag liggen en zijn voor een ander deel ook het gevolg van aanzienlijke verschillen tussen de geldende criteria voor toe- en uittreding, premie- en uitkeringshoogten e.d..

Evenals bij de fiscaliteit worden veel problemen veroorzaakt door een zeer gebrekkig informatieniveau bij de pendelaars. Daarbij speelt niet alleen de complexiteit van de betreffende regelingen een rol maar ook het feit dat begrijpelijke, op de persoonlijke situatie toegesneden informatie en advies, op slechts enkele plaatsen voorhanden is. Naast de grote informatiebehoefte doet zich het probleem voor dat de bij het uitvoeringsproces betrokken instanties in geringe mate met elkaar samenwerken en vaak nogal 'landinwaarts' zijn gericht. Onnodig lange, omslachtige en voor de burger frustrerende procedures zijn daarvan het gevolg.

Enkele beleidsaanbevelingen:

* $\mathrm{Bij}$ het ontwikkelen en vaststellen van nieuwe wet- en regelgeving op met name het gebied van de sociale zekerheid, wordt nog steeds in onvoldoende mate rekening gehouden met de gevolgen daarvan voor grensoverschrijdende werknemers. Euregionale politici en belangenorganisaties zullen daarop alert moeten zijn.

* Er zal op grotere schaal en op een meer cliëntgerichte wijze informatie en advies beschikbaar moeten komen over de gevolgen voor de sociale zekerheid, van het werken in het buitenland.

* De bij de beleidsaanbevelingen op fiscaal terrein reeds genoemde beleidsaanbevelingen op het terrein van grensoverschrijdende rechtsbijstand, informatielacunes en uitvoeringsprocedures zijn onverkort van toepassing op het gebied van de sociale zekerheid.

\section{ALOEMENE AANDACHTSPUNTEN VOOR DE BELEVDSONTMKKELNC}

In het rapport wordt naast de diverse beleidsaanbevelingen op het terrein van de genoemde vier themagebieden ook een negental uitgangspunten geformuleerd waarmee bij de ontwikkeling van grensoverschrijdend beleid rekening zou moeten worden gehouden. Het gaat daarbij om de volgende aandachtspunten:

- ontwikkelen van een visie op de Euregio Maas-Rijn als bestuurlijke entiteit;

- het formuleren van een motiverend en inspirerend beleidskader voor Euregionale samenwerking;

- bezinning op succes- en faalfactoren van grensoverschrijdende samenwerking;

- meer aandacht voor potentiële pendelaars;

- meer aandacht voor de informatieverstrekking aan het midden- en kleinbedrijf en zelfstandige beroepsbeoefenaren;

- netwerkvorming in de Euregio en tussen Euregio's;

- uitwerken van de mogelijkheden voor incentive-sturing;

- uitwerken van een juridisch (bestuursrechtelijk) kader voor samenwerkingsprojecten;

- meer aandacht voor pendelaspecten bij het totstandkomen van nieuwe wet- en regelgeving, met name op het terrein van de sociale voorzieningen 



\section{NAAR EEN EUREGIONALE ARBEIDSMARKT}

Hoewel het aan de ene kant aantrekkelijk is dat een grote verscheidenheid aan organisaties een bijdrage levert aan de totstandkoming van een Euregionale arbeidsmarkt, kan dit tegelijkertijd ook nadelig zijn indien allerlei initiatieven elkaar overlappen of zonder enige coördinatie worden ontwikkeld.

Voor een meer gecoördineerde aanpak waarvan het geheel meer is dan de som der delen, zal in eerste instantie binnen de Euregio Maas-Rijn een vijftal beleidsinitiatieven nuttig kunnen zijn:

- het formuleren van een politieke visie op de mogelijkheden en wenselijkheden ten aanzien van de bestuurlijke samenwerking in de Euregio Maas-Rijn;

- het formuleren van een motiverend en inspirerend beleidskader, waarbinnen de verschillende meer concrete beleidsinitiatieven kunnen worden gepositioneerd;

- een aanzet geven tot de netwerkvorming binnen de Euregio, door het instellen van een 'Euregio Adviesraad' en thematische werkgroepen bestaande uit overheidsvertegenwoordigers, sociale partners en andere belanghebbenden (zie ook Buck, 1990);

- het voteren van regionale gelden ten behoeve van de beleidsterreinen die prioriteit hebben in het kader van de Euregionale samenwerking, in centrale Euregionale fondsen;

- het ontwikkelen van een actief informatiebeleid, waarmee de Euregio Maas-Rijn zich zowel binnen als buiten de Euregio kan profileren.

Vanuit de Initiatiefgroep Euregiocongres zou een appèl gedaan kunnen worden in de richting van het Gouverneursoverleg om op bovengenoemde punten beleidsinitiatieven te ontplooien.

Hoewel de ontwikkelingen op communautair en nationaal niveau vanzelfsprekend van groot belang kunnen zijn voor de totstandkoming van een gemeenschappelijke arbeidsmarkt in de Euregio Maas-Rijn, moet ook worden beseft dat juist de samenwerking in de grensregio's een belangrijke stimulans kan geven aan de Europese samenwerking in het algemeen. De Euregio's vervullen daarmee een belangrijke katalysatorfunctie voor het Europese integratieproces. 


Zusammenfassung 


Das magische 'Europa ohne Binnengrenzen' werden zweifellos in erster Linie vor allem die Bewohner der Grenzgebiete erleben oder, wie die Europäische Kommission (1990) selbst sagt: 'Es ist deutlich, daß die Grenzarbeiter durch die Verzögerung, die bei der Realisierung der Zielsetzungen der Europäischen Gemeinschaft auftreten kann, besonders betroffen sind.' Die Probleme, die sich trotz aller guten Absichten für die europäische Integration noch täglich in der Praxis zeigen, kommen daher sehr stark in einer der komplexesten Euregionen Europas zum Ausdruck. In der Euregion Maas-Rhein treffen sich nicht drei Nationalitäten, sondern auch drei unterschiedliche Sprach- und Kulturgebiete.

In der Euregion Maas-Rhein überschreiten täglich schätzungsweise 20.000 Personen die Landesgrenze, um zu ihrer Arbeitsstelle zu gelangen. Diese Pendelbewegung richtet sich hauptsächlich ostwärts. Es arbeiten relativ viele Belgier in den Niederlanden oder Deutschland und viele Niederländer in den deutschen Grenzgebieten.

Diese Studie wurde im Rahmen des euregionalen Kongresses 'Fiktion oder Wirklichkeit' über die Arbeitsmobilität in der Euregion Maas-Rhein, der am 28. November 1991 in Maastricht stattfinden wird, durchgeführt. Dabei wurden einige Engpässe betrachtet, die dem Funktionieren eines euregionalen Arbeitsmarktes ohne Binnengrenzen noch im. Wege stehen. Gleichzeitig wird ein Ansto $B$ zur Formulierung der arbeitspolitischen Initiativen, die das Zustandekommen eines solchen euregionalen Arbeitsmarktes schneller herbeiführen könnten, gegeben. In dem Bericht wird folgenden vier Themen Aufmerksamkeit gewidmet: Arbeitsmarkt; Bildung und Ausbildung; Fiskus und Finanzen; Soziale Sicherheit und Pensionen. Je Thema werden einige der wichtigsten Engpässe und bereits entfaltete Initiativen kurz dargelegt. Danach werden einige Möglichkeiten für eine neue Politik besprochen. Für eine globale Übersicht über die Engpässe und die bereits ausgeführten Aktivitäten und arbeitspolitischen Initiativen wird auch auf die Schemas 1 bzw. 2 des Untersuchungsberichtes hingewiesen.

\section{ARBETTSMART}

Bis heute kommt der größte Teil der internationalen Arbeitsmobilität durch Aktionen einzelner Arbeitgeber oder Arbeitnehmer zustande. Die einzelnen Behörden und Arbeitsverwaltungen spielen bei der Förderung eines freien Verkehrs von Arbeitnehmern fürs erste nur eine bescheidene Rolle. Die grenzüberschreitende Vermittlung der Arbeitsverwaltungen findet oft über persönliche Kontakte der Vermittler und den Austausch von Informationen über offene Stellen statt. Dieser Austausch hat sich an einigen Orten als relativ erfolgreich erwiesen. Der automatisierte Austausch über Stellenangebote zwischen den Arbeitsämtern verläuft dagegen noch etwas träge, u.a. infolge der unterschiedlichen Systeme für die Anmeldung offener Stellen in den einzelnen Ländern. Außerdem scheint die Erfolgsquote einer Vermittlung begrenzt zu sein, wenn bei Arbeitgebern und (potentiellen) Pendlern nicht genug Einsicht in das Verhältnis von Angebot und Nachfrage auf der anderen Seite der Grenze besteht. Engpässe treten dabei sowohl wegen fehlenden Datenmaterials als auch wegen des Fehlens einer integrierten Aufklärung mit niedriger Schwelle auf. Vor allem die kleinen und mittleren Unternehmen kennen oft den Wert der Diplome aus den Nachbarländern nicht. Vor kurzem wurden auf dem Gebiet der Aufklärung wichtige Initiativen ergriffen, wie der geplante 'Euroschalter' der Arbeitsverwaltung.

Einige arbeitspolitische Empfehlungen:

* Eine inventarisierende Untersuchung nach dem Informationsbedarf der einzelnen Zielgruppen in der Euregion und die Möglichkeiten, diesen Informationsbedarf zu befriedigen, sind erwünscht.

* Die zur Euregion gehörenden Behörden müßten sich für eine einheitliche übergreifende und integrierende Aufklärungspolitik entscheiden, um eine Zersplitterung der Initiativen von getrennten Kreisen aus zu verhindern. 

* Das Büro der Euregion Maas-Rhein könnte bei der Erweiterung der Kenntnisse (Zielgruppe, Bereich, Kosten) bei lokalen Medien und Betrieben über die unterschiedlichen Werbemöglichkeiten, -kanäle und -verfahren in der Euregion eine fördernde und initiierende Rolle spielen.

* Bei der Informationsverschaffung und dem Image in bezug auf Personen und Betriebe müssen nicht nur die augenblicklich bei der Grenzarbeit auftretenden Engpässe hervorgehoben werden, sondern vor allem auch die positiven Aspekte der Ausweitung des (eu)regionalen Arbeitsmarktes.

* Die einzelnen Behörden und (halb-)behördlichen Einrichtungen innerhalb der Euregion müßten auf dem Arbeitsmarkt eine Vorreiterrolle spielen können, wobei außerdem Kenntnis und Verständnis für die 'politische Kultur' der anderen in den Nachbarländern gefördert werden können. Vor allem der Austausch des ausführenden Personals u.dgl. in Form eines Praktikums bzw. einer zeitweiligen Entsendung könnte dabei eine wichtige Rolle spielen.

\section{BLDUNG UND AUSBLDUNG}

Verschiedene Faktoren erschweren die Möglichkeit, eine Ausbildung jenseits der Grenze zu absolvieren. Zwei Engpässe stehen dabei im Mittelpunkt:

- die Ausbildung ist nicht auf die Bedürfnisse auf der anderen Seite der Grenze abgestimmt; - man hat keinen direkten Zugang zu dem Ausbildungssystem in den Nachbarländern.

Außerdem fehlt es auch an einer Übersicht über Angebot und Nachfrage im Rahmen der Bildungs- und Ausbildungsmöglichkeiten und über die diesbezüglich geltenden Anforderungen an die Vorbildung. großes Problem ist auch die Anerkennung von Diplomen, auch wenn es inzwischen eine allgemeine Richtlinie für die Anerkennung von Hochschuldiplomen gibt und eine Richtlinie für Diplome und Zertifikate anderer Ausbildungen ausgearbeitet wird. Die Europäische Kommission hat bereits zahlreiche europäische Programme auf dem Gebiet von Bildung und Ausbildung initiiert.

In der Euregion Maas-Rhein gibt es im Augenblick einige grenzüberschreitende Ausbildungsprojekte. Diese Projekte sind hauptsächlich auf Initiative von Ausbildungsinstituten und Branchenorganisationen zustande gekommen. Auffallend ist, daß trotz möglicher Sprachprobleme bei weitem die meisten Projekte im niederländisch-deutschen Grenzbereich durchgeführt werden. Die Projekte im allgemeinen weiterführenden Unterricht scheinen sich fürs erste vor allem auf Kennenlernen und Austausch zu richten. Im berufsbildenden Unterricht ist dagegen des öfteren die Rede von gemeinsamen Ausbildungsprojekten, die sich u.a. auf Gesundheitswesen, Wirtschafts- und Verwaltungsunterricht, Prozeßtechnologie und Computersimulation, Metallbearbeitung und internationalen Transport beziehen.

Einige arbeitspolitische Empfehlungen:

* Initiativen, die sich auf die Integration von Ausbildungsprogrammen richten, sind von großer Bedeutung.

* Es müßte eine Bestandsaufnahme von den formellen, organisatorischen und finanziellen Hindernissen, die einer solchen Integration im Wege stehen, gemacht werden.

* Die Zuschußgeber für Ausbildungsprojekte in der Euregion Maas-Rhein (Behörden, Ausbildungsfonds) müßten ein gemeinsames Ausbildungsprogramm mit gemeinsamen Zuschußbedingungen initiieren können.

* Ein 'euregionaler Aktionsplan Sprachen in der Region' erscheint wünschenswert.

* Es muß geprüft werden, inwieweit in der Euregion Maas-Rhein Bedarf an einer Institution für das Initiieren und Koordinieren von grenzüberschreitenden Berufsausbildungen und Fachkursen besteht. Durch die Zusammenarbeit und Abstimmung im Bereich der Ausbildungen, Weiterbildung und Prüfungen müssen allmählich die Ausbildungsqualifikationen von Fachkräften gleichgeschaltet werden, wodurch die Mobilität der Arbeitnehmer zunehmen kann. 
SOZIAL SICHEI

lufgrund einer euro stemen der sozialen Praxis noch imm ähigkeit und den Alt piell unterschiedlich liegen, verursacht. Si

Teil die Folge der רd Abgang, Höhe der

ie bei der Steuerges nsniveaus bei den $P$ en eine Rolle, sonde zugeschnittene Inforr fformationsbedarf $\mathrm{tr}$ I Instanzen kaum zu: Inge, umständliche $u$

seitspolitische Empfe Entwickeln und Erla in Sicherheit werde unzureichend ber! n darauf achten müs: Issen in größerem $U$ latschläge über die jung gestellt werden. ei den politischen iberschreitender $\mathrm{Re}$ verständlich auch für

\section{MENNE SCHMER}

3ericht werden auß $n$ vier Themen auc rschreitenden Politik Inkte:

*klung einer Vision a ormulieren einer mot nung auf Erfolgs- $\iota$

'Aưmerksamkeit für Aufmerksamkeit für en und selbständige rerkbildung in der Eu beitung der Möglichl beitung eines juristis Aufmerksamkeit für hriften, vor allem im

\section{FISKUS UND FINANZEN}

Die Probleme, die im Steuer- und Finanzbereich sowie auf dem Gebiet der sozialen S auftreten, lassen sich in vier Gruppen von Engpässen unterscheiden:

1. Probleme infolge zueinander im Widerspruch stehender Gesetze und Vorschriften;

2. Probleme infolge unrichtiger oder unzureichender Informationen für Pendler $i$ relevanten Gesetze und Vorschriften;

3. Probleme infolge von einander überlappender oder sich wiederholender Ausf। verfahren;

4. Probleme infolge undurchsichtiger Berufungsmöglichkeiten oder das Fehlen eines ac Rechtsbeistandes.

Für Pendler zwischen Belgien und den Niederlanden treten infolge eines adäquaten bi Steuervertrages im Bereich der persönlichen Einkommensteuer wenig Probleme auf. , Schwierigkeiten stoßen belgische und niederländische Pendler, die in Deutschland Diese Schwierigkeiten beziehen sich auf ungünstige Einteilungen in Tarifgruppen und Möglichkeiten, verschiedene Unkosten in Abzug zu bringen. Dadurch werden vc Selbständige, allein- erziehende Elternteile und Zeitkräfte unverhältnismäßig schwer Vorläufig scheint sich die Situation nicht zu bessern, z.B. durch Anpassungen der Landes und -vorschriften aufgrund einer europäischen Richtlinie oder durch bilaterale Verträge.

Die Informationsverschaffung in bezug auf die Lohnsteuerprobleme von Pendlern ist noc sehr unzureichend. Einige private Organisationen (belgische Gewerkschaften, ein Verk Grenzlandbewohner) verfügen über ein breites Sortiment von Aufklärungsmaterial, das । nur für Mitglieder/Pendler bestimmt ist. Diese Informationen erreichen leider die Betriebe und Selbständigen nicht. Die Steuerbehörden selbst sind auf diesem Gebiet no aktiv. Bei der Steuereinziehung sind neben dem Finanzamt auch die Arbeitgeber । leistungzahlenden Instanzen wie Bedrijfsverenigingen (niederländische Sozialversicl träger) oder Pensionskassen beteiligt. Bei der praktischen Ausführung gibt es kal Zusammenarbeit oder Abstimmungen zwischen den Interessenten. Auch die Möglichk grenzüberschreitenden Berufungsverfahren und mögliche Rechtsverfahren für inc Pendler scheinen in der Praxis kaum realisierbar zu sein.

Einige arbeitspolitische Empfehlungen:

* In bezug auf die Ausführung der bilateralen Steuerverträge zwischen den Nied€ Belgien und Deutschland könnte für die Pendler eine beträchtliche Verbesserung stelligt werden, wenn der Arbeitgeber und die zahlenden Instanzen für das Beantrag Befreiung zur Einziehung der direkten Einkommensteuer (die Grenzarbeitere। verantwortlich wären.

* Um die Arbeitsmarktmobilität von Deutschland aus in die Niederlande und nach Bel! von den Niederlanden aus nach Belgien zu vergrößern, müssen auch Informatior Engpässe, die bei diesen (potentiellen) Pendelströmen auftreten können, gesammelt v

* Es muß geprüft werden, ob auf dem Gebiet des grenzüberschreitenden Rechtsbe Maßnahmen getroffen werden können. Es handelt sich dabei um die Unterstützung ‘ Pendler bei Rechtsverfahren, die Stimulierung von Versuchsprozessen, das Zu! machen bzw. Erschließen von Vorschriften, Rechtsprechung usw.

* Möglicherweise gibt es in Belgien und der Bundesrepublik Deutschland Möglichke Steuerinformationen für Pendler übersichtlicher zu gestalten.

* Die grenzüberschreitenden Ausführungsverfahren müßten von bilateralen Projektte 'Pendler-Freundlichkeit' untersucht werden. Die Büros für belgische und deutsche An heiten müßten dafür Zuschüsse für den Personalbestand erhalten. 



\section{AUF DEM WEG ZU ENEM EUREGIONALEN ARBEITSMARKT}

Obwohl es einerseits reizvoll ist, daß eine große Verschiedenheit an Organisationen einen Beitrag zum Zustandekommen eines euregionalen Arbeitsmarktes leistet, kann das gleichzeitig auch Nachteile haben, und zwar dann, wenn verschiedene Initiativen einander überlappen oder ohne irgendeine Koordination entwickelt werden.

Für eine gut koordinierte Inangriffnahme, deren Ganzes mehr ist als nur die Summe der Teile, werden in erster Linie innerhalb der Euregion Maas-Rhein fünf politische Initiativen nützlich sein können:

- die Formulierung einer politischen Vision auf die Möglichkeiten und Wünsche in bezug auf die verwaltungstechnische Zusammenarbeit in der Euregion Maas-Rhein;

- die Formulierung eines motivierenden und inspirierenden politischen Konzeptes, in das die einzelnen konkreten Initiativen eingefügt werden können;

- einen Anstoß zu der Netzwerkbildung innerhalb der Euregion geben, indem ein 'Euregion Beratungsgremium' und thematische Arbeitsgruppen, zu denen Vertreter der Regierung, der Sozialpartner und anderer Interessenten gehören (siehe auch Buck, 1990), gebildet werden.

- die Bewilligung regionaler Gelder für die Politikbereiche, die im Rahmen der euregionalen Zusammenarbeit Priorität haben. Die Gelder werden in zentrale euregionale Fonds eingezahlt.

- die Entwicklung einer aktiven Informationspolitik, mit der sich die Euregion Maas-Rhein sowohl innerhalb als außerhalb der Euregion profilieren kann.

Die Initiativgruppe des Euregionkongresses könnte den Verhandlungsausschuß der Gourverneure auffordern, in bezug auf die obigen Aspekte politische Initiativen zu entfalten.

Obwohl die Entwicklungen auf Landes- und EG-Ebene für das Zustandekommen eines gemeinsamen Arbeitsmarktes in der Euregion Maas-Rhein selbstverständlich von großer Bedeutung sein können, sollte man nicht übersehen, daß gerade die Zusammenarbeit in den Grenzgebieten ein wichtiger Anreiz für die europäische Zusammenarbeit im allgemeinen sein kann. Die Euregionen erfüllen damit eine wesentliche Katalysatorfunktion für den europäischen Integrationsprozeß. 

Synthese 

Le monde idéal de l'Europe sans frontières" sera sans aucun doute vécue comme une réalité, en tout premier lieu, par les habitants des régions frontalières. Comme le dit la Commission européenne (1990), "il est clair que le retard susceptible d'affecter la réalisation des objectifs de la Communauté européenne a un impact tout particulier sur les travailleurs frontaliers.

On comprendra donc que les problèmes concrets qui se posent encore quotidiennement, en dépit de tous les projets d'intégration européenne, pèsent spécifiquement sur l'une des "Eurégions" les plus complexes d'Europe, à savoir l'Eurégion Meuse-Rhin. Celle-ci, en effet, ne réunit pas seulement trois nationalités, mais également trois territoires linguistiques et culturels.

Dans cette région, on estime à quelque 20.000 le nombre de personnes qui franchissent chaque jour la frontière de leur pays pour se rendre à leur travail. La direction principale de ce mouvement pendulaire est l'est: les Belges travaillant aux Pays-Bas et en Allemagne sont relativement nombreux, de même que les Néerlandais dans les régions frontalières allemandes.

La présente étude s'insère dans le cadre du Congrès eurégional "Fiction ou réalité", sur la mobilité de la main-d'oeuvre dans l'Eurégion Meuse-Rhin, qui se déroulera à Maastricht le 28 novembre 1991. Elle se penche sur un certain nombre d'obstacles au bon fonctionnement d'un marché du travail eurégional sans frontières qui continuent de subsister. Au-delà de la simple identification des problèmes, elle suggère un certain nombre d'initiatives politiques susceptibles de nous rapprocher d'un véritable marché eurégional du travail.

Le rapport aborde successivement les quatre thèmes suivants: marché du travail, enseignement et formation, fiscalité et financement, sécurité sociale et régimes de pensions. II rappelle brièvement, pour chacun de ces thèmes, les obstacles majeurs et les initiatives déjà prises. II propose ensuite une série de nouvelles voies d'action. Les schémas 1 et 2 du rapport de recherche présentent une vue d'ensemble des freins subsistants, ainsi que des activités déjà en cours et des initiatives politiques déjà prises.

\section{LE MARCHE DU TRAVAL}

Jusqu'ici, la majeure partie de la mobilité internationale de la main-d'oeuvre est le fait d'employeurs ou de travailleurs individuels. Les diverses administrations compétentes et les Services pour l'Emploi ne jouent encore qu'un rôle modeste en matière de promotion de la libre circulation des travailleurs. L'essentiel des activités transfrontalières de placement assurées par les Services pour l'Emploi trouvent leur source dans les contacts personnels et les échanges d'information sur les offres d'emploi entre agents de placement. Une telle collaboration semble produire déjà de bons résultats en un certain nombre d'endroits. Par contre, l'échange informatisé d'information sur les offres d'emploi entre Services pour l'Emploi reste hésitant, en raison notamment des différences entre systèmes nationaux d'enregistrement des offres d'emploi. S'y ajoute le fait que les chances de succès d'un placement transfrontalier restent limitées en l'absence d'une bonne connaissance, par les employeurs et par les travailleurs frontaliers potentiels, des relations entre l'offre et la demande de travail de l'autre côté de la frontière. Les problèmes résultent ici, soit de l'indisponibilité de l'information de base, soit de la difficulté d'accès à celle-ci, par manque d'intégration. En particulier, les petites et moyenne entreprises connaissent mal la valeur des diplômes délivrés dans les pays voisins. Des initiatives ont récemment été prises en vue d'améliorer cet accès à l'information, notamment sous la forme du projet d"'Euroguichet" des Services pour l'Emploi. 

Quelques recommandations d'action:

* Identification des besoins d'information des divers groupes-cibles de l'Eurégion et des possibilités de les rencontrer.

* Adoption, par les administrations concernées de l'Eurégion, d'une structure fédérative d'information harmonisée et intégrée, en vue d'éviter la dispersion des initiatives émanant des différents circuits.

* Rôle de pionnier et de promoteur du Bureau de l'Eurégion Meuse-Rhin en matière d'amélioration de l'information (groupes-cibles, portée, coûts) des médias et des employeurs locaux sur les possibilités, canaux et procédures de recrutement dans l'ensemble de l'Eurégion.

* Accent mis, dans l'effort d'information auprès des individus et des entreprises, non seulement sur les obstacles actuels, mais aussi et surtout sur les aspects positifs de l'élargissement du marché du travail (Euro)régional.

* Possibilité d'initiative des divers pouvoirs publics et organismes (para)publics de l'Eurégion, en matière de gestion du marché du travail et de promotion de la connaissance et de la compréhension réciproques des "cultures administratives" des pays voisins. Les échanges de collaborateurs, dans le cadre de stages ou de procédures de détachement, pourraient s'avérer particulièrement fructueux à cet égard.

\section{ENSEICNEMENT ET FORMATON}

Parmi le grand nombre de facteurs qui continuent à faire obstacle à la poursuite de formations audelà des frontières, nous en retiendrons deux, en raison de leur importance spécifique:

- absence d'alignement des formations sur les besoins de l'autre côté de la frontière;

- absence d'accès direct aux systèmes éducatifs des pays voisins.

S'y ajoute l'absence d'une vue d'ensemble aisément accessible de l'offre et de la demande de filières d'enseignement et de formation et de leurs prérequis. II demeure, en outre, un problème majeur de reconnaissance mutuelle des diplômes, en dépit de la Directive générale sur la reconnaissance des diplômes de l'enseignement supérieur et de la préparation d'une Directive sur les diplômes et certificats de l'enseignement secondaire. On rappellera, à cet égard, les très nombreuses initiatives prises par la Commission européenne en matière d'enseignement et de formation.

Un certain nombre de projets de formation transfrontaliers sont actuellement envisagés dans l'Eurégion Meuse-Rhin. L'initiative en est essentiellement due à des institutions éducatives et organismes professionnels. On remarquera que la possibilité de problèmes d'ordre linguistique n'empêche pas que la plupart de ces projets se situent dans la région frontalière Pays-BasAllemagne. Les projets concernant l'enseignement général du second degré semblent toutefois se limiter encore à des prises de contact et à l'initiation d'échanges. Dans l'enseignement professionnel, au contraire, il s'agit plus souvent de projets communs de formation portant, notamment, sur les soins de santé, l'économie et l'administration, la technologie des processus, la simulation informatisée, la transformation des métaux et le transport international.

Quelques recommandations d'action:

* Importance des initiatives visant l'intégration des programmes d'enseignement.

* Identification des obstacles institutionnels, organisationnels et financiers à une telle intégration.

* Possibilité pour les pouvoirs subsidiants de projets de formation en Eurégion (pouvoirs publics, fonds scolaires), de lancer un programme-cadre de formations régi par des conditions de financement communes. 

* Plan d'action Eurégional en faveur des langues de la région.

* Étude de l'intérêt, en Eurégion, d'un organisme chargé de mettre sur pied ou de coordonner des formations professionnelles transfrontalières ou des cours spécialisés. La collaboration et la concertation en matière de formation, d'apprentissage et de procédures d'examen sont, en effet, génératrices d'harmonisation progressive des qualifications professionnelles et donc de mobilité accrue des travailleurs.

\section{FISCALTEE ET FINANCEMENT}

En matière de fiscalité, de financement et de sécurité sociale, les problèmes peuvent être classés en quatre groupes:

1. Problèmes résultant de différences d'ordre législatif et réglementaire;

2. Problèmes suscités par l'information incorrecte ou insuffisante des travailleurs transfrontaliers sur les législations et réglementations pertinentes;

3. Problèmes liés au dédoublement ou aux interférences des procédures administratives;

4. Problèmes dus au manque de transparence du marché du travail ou à l'absence d'une assistance juridique appropriée.

Entre la Belgique et les Pays-bas, peu de problèmes se posent en ce qui concerne l'impôt sur les personnes physiques, grâce à l'existence d'un accord fiscal bilatéral adéquat. La situation est nettement moins aisée pour les Belges et les Néerlandais qui travaillent en Allemagne, où ils se heurtent à un traitement fiscal défavorable et à l'impossibilité de déduire un certain nombre de frais professionnels. II en résulte une charge fiscale particulièrement lourde pour les indépendants, les parents isolés et les travailleurs à temps partiel. II n'y a, à l'heure actuelle, que de faibles perspectives d'amélioration de cette situation, notamment par adaptation des législations et réglementations nationales sur la base d'une directive européenne ou de traités bilatéraux.

L'information des travailleurs frontaliers sur la fiscalité des revenus du travail reste loin d'être satisfaisante. Certains organismes privés (syndicats belges, une association d'habitants de la région transfrontalière) disposent d'un large éventail de moyens d'information, mais ceux-ci sont le plus souvent réservés à leurs membres ou aux travailleurs frontaliers, sans toucher les petites entreprises et les indépendants, notamment. Quant aux administrations fiscales elles-mêmes, elles ne font pratiquement rien à cet égard.

Outre ces administrations fiscales, les employeurs et/ou les organismes de paiement des allocations/indemnités tels qu'associations professionnelles ou fonds de pension, interviennent au niveau de la perception de l'impôt. En pratique, cependant, pratiquement aucune collaboration ou concertation n'existe entre les diverses parties concernées. Enfin, les possibilités de procédures d'appel, éventuellement en justice, pour les travailleurs frontaliers individuels semblent, en pratique, difficilement envisageables.

Quelques recommandations d'action:

* En ce qui concerne l'application des traités fiscaux bilatéraux entre Les Pays-Bas, la Belgique et l'Allemagne, la situation des travailleurs frontaliers serait considérablement améliorée si l'employeur et les organismes prestataires concernés assumaient la responsabilité de la demande de dégrèvement du précompte ( la "déclaration du travailleur frontalier").

* En vue d'accroître la mobilité des travailleurs de l'Allemagne vers les Pays-Bas et la Belgique autant que des Pays-Bas vers la Belgique, il convient d'identifier les obstacles à ces mouvements pendulaires (potentiels). 

* Des mesures peuvent être envisagées en matière d'assistance juridique transfrontalière. On songe notamment, à cet égard, à une assistance individuelle aux travailleurs frontaliers dans leurs procédures en justice, à l'encouragement de procès-tests, à la promotion de l'accès à et de l'information sur les réglementations et la jurisprudence, etc.

* Une plus grande transparence de l'organisation de l'administration fiscale compétente pour les travailleurs frontaliers est sans doute possible en Belgique et en Allemagne.

* Les procédures administratives de mise en oeuvre devraient être soumises à des équipes transfrontalières chargées les rendre plus accueillantes pour le travail transfrontalier. Les Bureaux des Affaires belges et allemandes devraient être dotés à cette fin du personnel nécessaire.

\section{SECURTEE ET PRESTATONS SOCIALES}

En dépit de la coordination entre régimes nationaux de sécurité sociale instaurée par une Directive européenne, les navetteurs individuels sont toujours confrontés, dans la vie quotidienne, à des difficultés, essentiellement en matière frais de maladie, d'incapacité de travail, d'assurancevieillesse et de pensions. Ces problèmes sont imputables, d'une part aux principes de base différents sur lesquels sont fondés les divers systèmes nationaux de sécurité sociale et, d'autre part aux différences dans les critères d'entrée et de sortie, dans les niveaux d'indemnisation et d'allocations, etc.

Comme en matière fiscale, l'information insuffisante des travailleurs frontaliers concernés est à la base d'un grand nombre de difficultés. Ceci s'explique, non seulement par la complexité intrinsèque des réglementations, mais aussi par la rareté des endroits où il est possible d'obtenir une information et des conseils personnalisés en fonction des situations individuelles. S'y ajoute, comme facteur explicatif, une collaboration entre organes exécutifs, non seulement réduite mais souvent encore orientée vers la solution de problèmes nationaux. Ceci se traduit par des procédures inutilement longues, complexes et frustrantes pour le citoyen.

Quelques recommandations d'action:

* L'élaboration et la mise en oeuvre de nouvelles législations et réglementations continuent de tenir insuffisamment compte de l'impact de celles-ci sur les travailleurs transfrontaliers. Les responsables politiques et les groupes d'intérêt de l'Eurégion devront rester vigilants à cet égard.

* On s'efforcera de fournir beaucoup plus largement une information mieux orientée vers l'usager sur les conséquences du travail transfrontalier en matière de sécurité sociale.

* Les recommandations formulées en matière fiscale dans le sens de l'assistance judiciaire, de l'information et de l'amélioration des procédures administratives s'appliquent, bien entendu, également au domaine de la sécurité sociale.

\section{AXES DACTON DNTERET CENERAL}

Outre les recommandations spécifiques à chacun des domaines décrits ci-dessus, le rapport propose également neuf principes de base susceptibles d'orienter la politique transfrontalière:

- développement d'une approche de l'Eurégion en tant qu'entité administrative;

- élaboration d'un cadre d'action motivant et innovateur;

- étude des facteurs de succès et d'échec de la collaboration transfrontalière;

- attention accrue aux travailleurs transfrontaliers potentiels; 

- attention accrue aux PME et indépendants;

- constitution de réseaux au sein de l'Eurégion autant qu'entre Eurégions;

- étude des possibilités d'une gestion par objectifs;

- élaboration d'un cadre juridique (administratif) d'insertion des projets de collaboration;

- attention accrue pour l'impact sur le travail transfrontalier des législations et réglementations nouvelles, notamment en matières de prestations sociales.

\section{EN ROUTE POUR UN MARCHÉ DU TRAVAL EUREGIONAL}

La multiplicité des organisations qui oeuvrent à la réalisation d'un marché du travail eurégional peut s'avérer intéressante, pourvu qu'elle ne donne pas lieu à des doubles emplois ou à une dispersion d'initiatives non coordonnées.

En vue d'assurer une coordination allant au-delà de la simple juxtaposition d'efforts individuels, cinq orientations d'action s'imposent a priori à l'Eurégion Meuse-Rhin:

- élaboration d'une approche politique de ce qui est possible et souhaitable en matière de collaboration administrative au sein de la région;

- mise en place d'un cadre motivant et innovateur d'insertion des diverses actions plus concrètes;

- initiation de la constitution de réseaux au sein de l'Eurégion, par la mise en place d'un "Conseil Consultatif de l'Eurégion" et de groupes des travail thématiques composés de représentants des pouvoirs publics, des partenaires sociaux et des autres parties concernées (voir également Buck, 1990);

- allocation à des Fonds eurégionaux centraux de moyens financiers régionaux réservés aux domaines d'action prioritaires dans le cadre de la collaboration eurégionale;

- mise au point d'une politique d'information dynamique permettant à l'Eurégion Meuse-Rhin de se positionner, tant sur son territoire que face au monde extérieur.

Le groupe initiateur du Congrès eurégional pourrait inviter le Comité de concertation des Gouverneurs à prendre des initiatives dans les domaines suggérés ci-dessus.

Si les évolutions aux niveau national et communautaire ont, cela va de soi, un impact important sur la réalisation d'un marché du travail communautaire dans l'Eurégion Meuse-Rhin, la collaboration au sein de celle-ci peut, à son tour, contribuer de manière significative à la coopération européenne en général. En cela, les Eurégions assument une importante fonction de catalyseurs du processus de l'intégration européenne. 




\section{INLEIDING}

Het magische 'Europa zonder binnengrenzen' zal ongetwijfeld vooral door de bewoners van de grensstreken aan den lijve ondervonden moeten gaan worden of zoals de Europese Commissie (1990) zelf aangeeft: 'het is duidelijk dat de grensarbeiders bijzonder getroffen worden door de vertraging die bij de verwezenlijking van de doelstellingen van de Europese Gemeenschap kan optreden'. De problemen die zich ondanks alle voornemens voor de Europese integratie, nog dagelijks voordoen bij 'mensen van vlees en bloed', komen dan ook zeer sterk naar voren in één van de meest complexe Euregio's van Europa. In de Euregio Maas-Rijn komen niet alleen drie nationaliteiten bij elkaar, maar ook drie verschillende taal- en cultuurgebieden. Dat er echter ook grote mogelijkheden voor de Euregio Maas-Rijn zijn weggelegd, wordt onder meer geschetst in het rapport van de Commissie 'Toekomst Limburg' (Buck, 1990). In dit rapport wordt onder meer opgeroepen tot de ontwikkeling van een Euregionaal Deltaplan voor de arbeidsmarkt, waarbinnen de internationalisering van de arbeidsmarkt een belangrijke plaats zal moeten innemen.

In deze studie zal nader worden ingegaan op de knelpunten die zich momenteel voordoen met betrekking tot het functioneren van de Euregionale arbeidsmarkt. Tevens zal een aanzet worden gegeven tot het formuleren van beleidsinitiatieven die de totstandkoming van een Euregionale arbeidsmarkt dichterbij zouden kunnen brengen.

Alvorens in te gaan op de knelpunten op de Euregionale arbeidsmarkt en de beleidsinitiatieven ter verbetering van het functioneren van deze Euregionale arbeidsmarkt, is het goed eerst stil te staan bij het grote economische en maatschappelijke belang dat bewoners en bedrijven in grensregio's kunnen hebben bij een goed functionerende Euregionale arbeidsmarkt ${ }^{1}$. Daarbij kan een onderscheid worden gemaakt tussen enerzijds het belang van het wegnemen van de momenteel door pendelaars en bedrijven ondervonden nadelen van respectievelijk het werken en werven over de grens en anderzijds de voordelen van de schaalvergroting, die zal optreden door het samengaan van enkele perifere regionale arbeidsmarkten tot een grotere Euregionale arbeidsmarkt.

Het wegnemen van bestaande starheden op de Euregionale arbeidsmarkt betekent voor werkenden, werklozen en schoolverlaters uit de grensregio's een vergroting van hun ontplooiingskansen op de arbeidsmarkt. Voor arbeidsorganisaties vergroot een goed functionerende Euregionale arbeidsmarkt het wervingsgebied bij het aantrekken van nieuw personeel. Bovendien vergroot de Euregionale arbeidsmarkt het verzorgingsgebied van onderwijsinstellingen, arbeidsvoorzieningsorganisaties, e.d., waardoor deze een groter marktgebied krijgen. Een nevenprodukt van de Euregionale arbeidsmarkt is verder dat aan weerszijden van de nationale grenzen op meer efficiënte wijze gebruik kan worden gemaakt van de economische en sociale infrastructuur, met als gevolg dat deze infrastructuur ook aanmerkelijk zou kunnen worden verbeterd. Kortom, in feite hebben we hier te maken met de gebruikelijke voordelen van het wegnemen van rigiditeiten op de arbeidsmarkt in combinatie met de schaalvoordelen als gevolg van het opgaan van perifere regionale arbeidsmarkten in een grote Euregionale arbeidsmarkt.

Naast de economische voordelen die een Euregionale arbeidsmarkt zou kunnen bieden, is het goed om te benadrukken dat het opheffen van de knelpunten bij pendelarbeid ook onder meer een vereiste is, vanuit het principiële punt dat pendelaars binnen de Europese Gemeenschap het recht hebben, niet benadeeld te worden ten opzichte van de andere werkenden in het land waar men werkzaam is. Bovendien zou de vorming van Euregio's een belangrijke schakel kunnen vormen in het Europese integratieproces in het algemeen, omdat van de Euregio's een voorbeeldwerking kan uitgaan voor het aanbrengen van veranderingen in nationale instituties die

1. Indien in dit rapport wordt gesproken over de Euregio wordt gedoeld op de Euregio Maas-Rijn. 

het integratieproces belemmeren. Tenslotte kan het integratieproces ook in culturele zin worden versneld. Bij de vorming van Euregio's kan de (her)ontdekking van een goede buurman naast de verre vrienden binnen de eigen landgrenzen in dit vlak nieuwe perspectieven openen.

De probleemstelling van deze studie is in feite drieledig:

- het verkrijgen van inzicht in de knelpunten die momenteel optreden bij de internationale arbeidsmobiliteit binnen de Euregio;

- het in kaart brengen van de reeds bestaande initiatieven die gericht zijn op het opheffen of verminderen van de gesignaleerde knelpunten;

- het aangeven van de mogelijk te nemen beleidsinitiatieven waarmee een bijdrage kan worden geleverd aan het verbeteren van het functioneren van de Euregionale arbeidsmarkt.

In eerste instantie is een groot aantal publikaties, zoals rapportages van eerder onderzoek, brochures, beleidsnota's en knipselkranten, geïnventariseerd (zie hiervoor de bijgevoegde literatuurlijst). Het grootste deel van de onderzoekwerkzaamheden bestond echter uit het voeren van gesprekken met direct betrokkenen zoals (groepen van) pendelaars en vakbondsvertegenwoordigers, werkgevers en personeelsfunctionarissen en inhoudsdeskundigen zoals wetenschappers en ambtenaren belast met beleidsvoorbereiding of -uitvoering (zie bijlage I). Typerende uitspraken of praktijkvoorbeelden van bepaalde knelpunten zijn ter illustratie van de hoofdtekst in het rapport opgenomen.

Zowel bij het in kaart brengen van de knelpunten, als bij het schetsen van de mogelijk te nemen (beleids)initiatieven, zal telkens ten behoeve van de overzichtelijkheid, naast de meer algemene punten, een indeling plaatsvinden in een viertal themagebieden:

- arbeidsmarkt;

- onderwijs en scholing;

- fiscus en financiën;

- sociale zekerheid en pensioenen.

Hoewel op het congres ook aandacht zal worden geschonken aan grensoverschrijdende investeringen valt dit onderwerp buiten het bestek van deze studie.

De verdere opzet van het rapport is als volgt. Eerst wordt in hoofdstuk 2 een globaal beeld geschetst van de arbeidsmarkt in de Euregio Maas-Rijn en de omvang van de huidige pendelstromen. Daarna komen in hoofdstuk 3 de knelpunten rondom pendelarbeid aan de orde. In dat hoofdstuk wordt aandacht geschonken aan de belangrijkste knelpunten die zich voor kunnen doen bij de vier door ons onderscheiden doelgroepen: pendelaars en potentiële pendelaars, werklozen en schoolverlaters aan de aanbodzijde van de arbeidsmarkt en werkgevers uit groot-, midden- en kleinbedrijf en zelfstandigen aan de vraagzijde van de arbeidsmarkt. Daarbij wordt in paragraaf 3.2. ingegaan op de knelpunten in de dataverzameling en informatievoorziening, waarna in paragraaf 3.3. de knelpunten themagewijs worden besproken. Vervolgens wordt in hoofdstuk 4 aandacht geschonken aan de inventarisatie van reeds bestaande activiteiten en beleidsinitiatieven die van belang kunnen zijn voor het verbeteren van het functioneren van de Euregionale arbeidsmarkt. In paragraaf 4.2. komen de terreinen waarop momenteel reeds actie wordt ondernomen themagewijs aan de orde. In paragraaf 4.3. worden enkele Euregionale initiatieven op het terrein van de voorlichting en enkele Euregionale scholingsprojecten nog nader belicht. In hoofdstuk 5 wordt eerst, in paragraaf 5.2., een aantal uitgangspunten geformuleerd voor het beleid ter verbetering van het functioneren van de Euregionale arbeidsmarkt. In paragraaf 5.3. wordt vervolgens een groot aantal aanbevelingen gedaan voor mogelijke beleidsinitiatieven. Tenslotte wordt in paragraaf 5.4. aangegeven welke belangrijkste eerste stappen binnen de Euregio Maas-Rijn moeten worden gezet om de totstandkoming van een Euregionale arbeidsmarkt te kunnen realiseren. 


\section{DE ARBEIDSMARKT IN DE EUREGIO MAAS-RIJN}

\subsection{LGCING EN BEVOLKNC}

De Euregio Maas-Rijn omvat op Belgisch grondgebied de provincies Luik en Limburg; in Nederland omvat het Zuid-Limburg en in Duitsland de districten Aken, Düren, Euskirchen en Heinsberg. De totale oppervlakte bedraagt ongeveer $11.000 \mathrm{~km}^{2}$.

Kaart 1. De Euregio Maas-Rijn

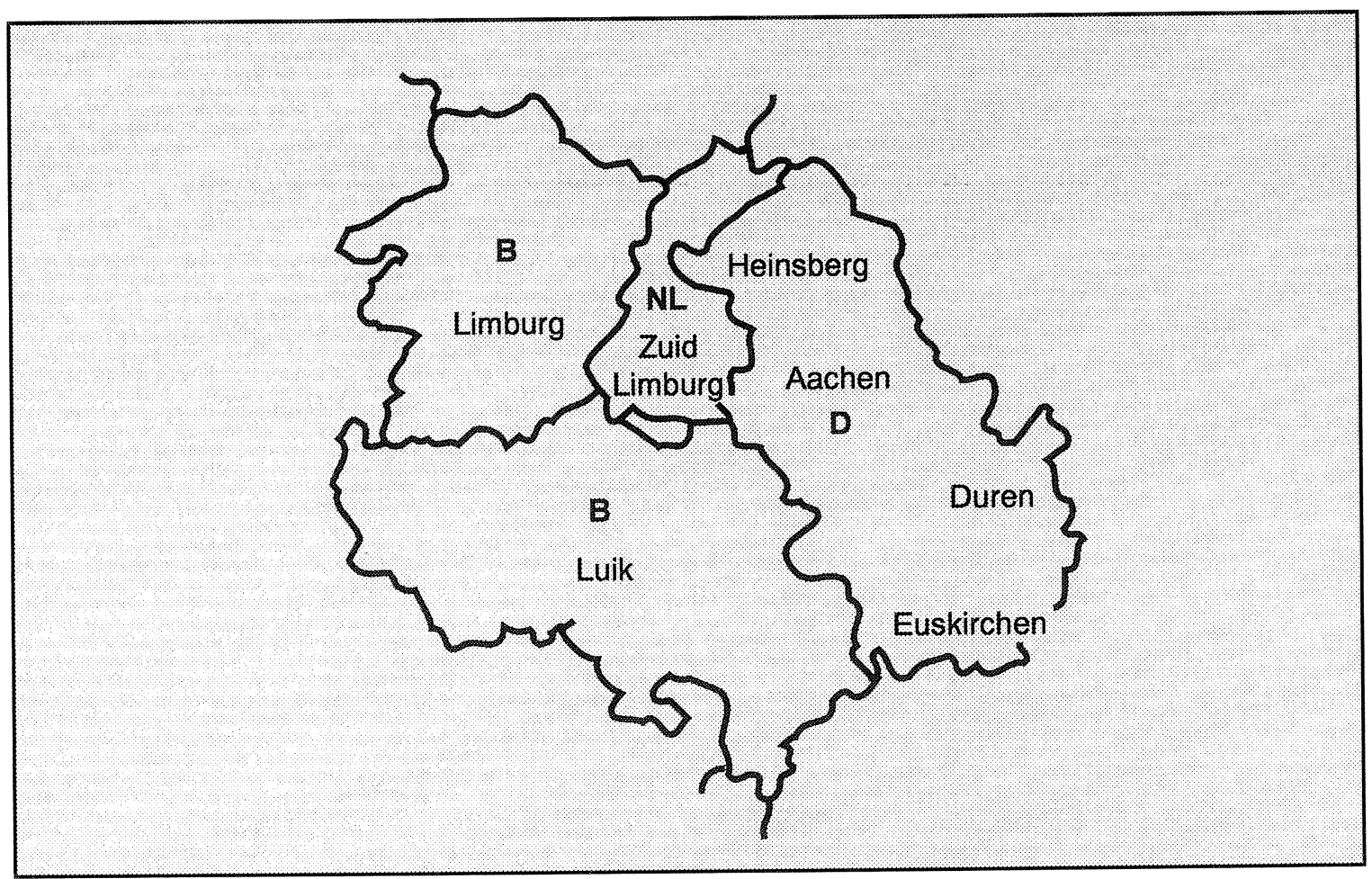

Bron: Goethals (1990)

In de Euregio wonen ruim 3,5 miljoen mensen. Het Duitse deel bevat 1,1 miljoen inwoners, de provincie Luik 1 miljoen en de beide Limburgse delen ruim 700.000 inwoners. Het Nederlandse deel is het dichtst bevolkt.

\subsection{ECONOMSGHE STRUCTUUR EN MERKOELECENHETD}

Aan de Limburgse Sociaal-Economische Verkenning 1990 van het Economisch Technologisch Instituut Limburg (ETIL) ontlenen we de volgende tabel over de economische structuur en werkgelegenheid in de Euregio. 

Tabel 1. Sectorale werkgelegenheid, werkloosheid, Bruto Regionaal Produkt en werkgelegenheidsgroei

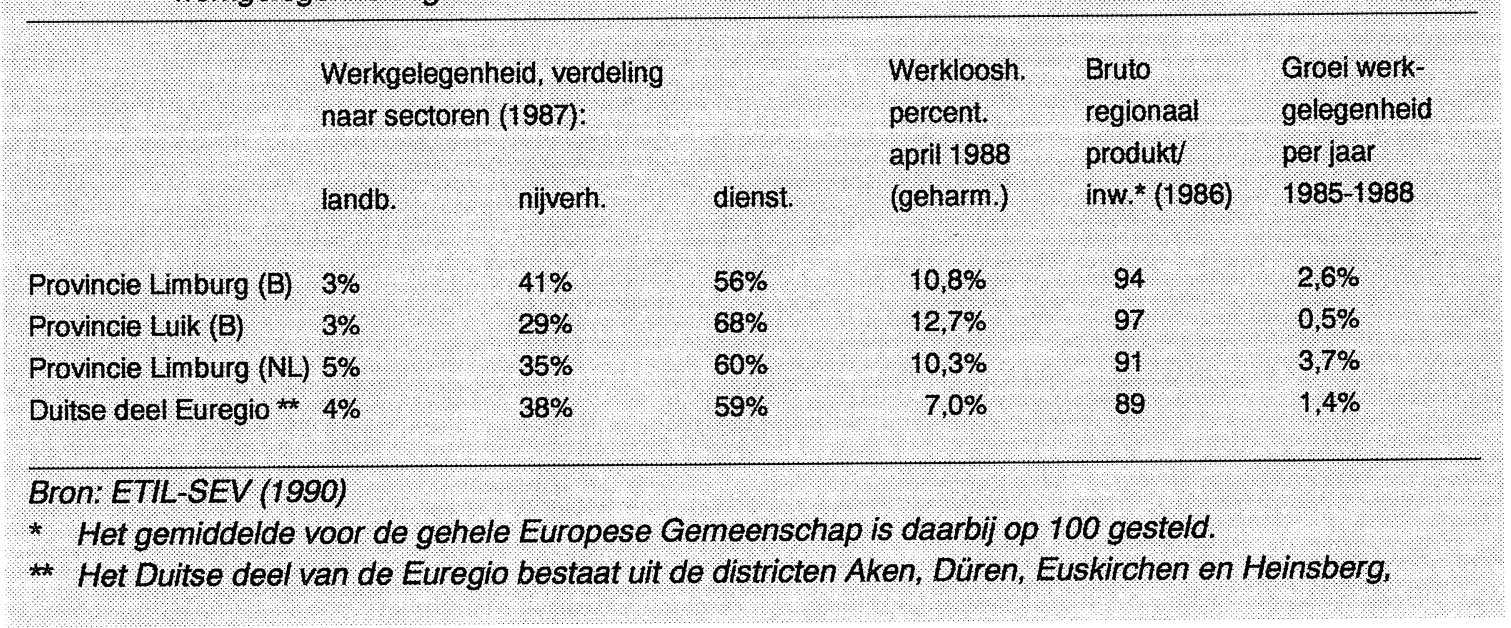

Belgisch Limburg wordt gekenmerkt door een relatief sterk aandeel van de nijverheid, met als de drie belangrijkste bedrijfstakken mijnbouw, transportmiddelen en metaal. De werkloosheid in deze provincie is relatief hoog. Daartegenover staat echter een relatief sterke groei van de werkgelegenheid.

De provincie Luik wordt gekenmerkt door een relatief sterk aandeel van de dienstensector. De belangrijkste industrietak is de metaal. De werkloosheid is hier evenals in Belgisch Limburg relatief hoog. De provincie Luik is overigens de Euregio Maas-Rijn de regio waar de werkgelegenheidsgroei tussen 1985 en 1988 het geringst is geweest.

Nederlands Limburg neemt wat de economische structuur betreft een tussenpositie in. Alleen de landbouw is relatief belangrijker dan in de overige regio's. De belangrijkste industriële bedrijfstakken zijn: chemie, hout/papier, steen/aardewerk/glas. De totale werkgelegenheid is na een relatief hoge werkloosheid, in het afgelopen decennium sterk gegroeid.

De industrie in het Duitse deel is nog sterker gediversifieerd dan in Nederlands Limburg. De belangrijkste industrietakken zijn: metaalbewerking en -verwerking, machinebouw, mijnbouw, hout en papier, steen/aardewerk/glas, electrotechniek, leder/textiel/kleding en de voedings- en genotmiddelenindustrie. De totale werkgelegenheid in deze regio is slechts licht gegroeid. De werkloosheid is hier echter het laagst van alle regio's.

\subsection{DE DENOELSTROMEN IN DE EURECIO MAAS.TWN}

Er zijn geen betrouwbare cijfers beschikbaar over de omvang van de pendelstromen binnen de Euregio Maas-Rijn. De bestaande cijfers hebben de volgende tekortkomingen:

- de gebiedsafbakening komt niet overeen met die van de Euregio;

- het gebruik van verschillende databronnen (b.v. ziekenfondsen, arbeidsvoorziening, arbeidskrachtentellingen) levert afwijkende resultaten op (zelfs binnen één land);

- er is sprake van schattingen door het ontbreken van een verplichte centrale registratie.

De hier te presenteren cijfers moeten daarom gezien worden als een indicatie van de totale pendelomvang. 

In het algemeen is de pendelstroom in de Euregio oostwaarts gericht: er werken relatief veel Belgen in Nederland of Duitsland en veel Nederlanders in de Duitse grensstreken. Van het omgekeerde is veel minder sprake. Op basis van gegevens van het Nederlandse Centraal Bureau voor de Statistiek (CBS) heeft het ETIL het volgende overzicht van de pendelstromen tussen Limburg, België en Duitsland samengesteld. Daarbij moet worden bedacht dat deze CBSgegevens gebaseerd zijn op het aantal grensarbeiders dat bij de ziekenfondsen staat ingeschreven. De grensarbeiders die niet via een ziekenfonds verzekerd zijn, zijn derhalve niet in deze cijfers opgenomen.

Tabel 2. Ontwikkeling van de pendel tussen Nederlands Limburg en België en Duitsland, (cijers 1 aprii)

\begin{tabular}{|c|c|c|c|c|c|c|}
\hline & 1985 & 1987 & & 1989 & & 1990 \\
\hline Pendel van Nederland naar Duitsland & 8322 & 8173 & $(8173)$ & 8290 & & 8620 \\
\hline Pendel Van Duitsland naar Nederland : & 518 & 594 & $(829)$ & 590 & & 600 \\
\hline Pendelsaldo van Nederland met Duitstand, uitgaand & 7804 & 7579 & $(7344)$ & 7700 & & 8020 \\
\hline Pendel van Nederland naar België & 870 & 815 & & 750 & {$[1127]$} & 810 \\
\hline Pendel van België naar Nederland & 5101 & 5853 & & 6460 & {$[10354]$} & 6470 \\
\hline Pendelsaldo van Nederland met België, inkomend & 4231 & 5038 & & 5710 & [9227] & 5660 \\
\hline Pendel van Belgiè naar Duitsland & & & & & [3102] & \\
\hline Pendel van Duitsland naar België & & & $(313)$ & & [288] & \\
\hline Pendelsaldo van België met Duitsland, uitgaand & & & & & {$[2814]$} & \\
\hline Pendelsaldo Nederland t.o.v. België-Duitsland & 3573 & 2541 & & 1990 & [1527] & 2360 \\
\hline Pendelsaldo Duitsland tio.v. Belgiè-Nederland & & & & -10514 & & \\
\hline Pendelsaldo België t.o.v. Duitsland-Nederland & & & & 8524 & & \\
\hline Totaal Euregio Maas-Rijn & & & & 19480 & {$[20361]$} & \\
\hline
\end{tabular}

Bron: ETIL/CBS

(..) Data afkomstig van Landesamt für Datenverarbeitung und Statistik Nordrhein-Westfalen (LDS-NW)*;

[.. Data afkomstig van Rijksinstituut voor Ziekte- en Invaliditeitsverzekering (RZI)**;

* In tegenstelling tot de CBS-data, die gebaseerd zin op grensarbeiders ingeschreven bij het ziekenfonds, zijn de gegevens van het Landesamt afkomstig uit een volkstelling.

** afwijking moet toegeschreven worden aan een verschil in de onderzochte groep. Het Rijksinstituut is uitgegaan van de algemene inspectie van sociale zekerheid.

De cijfers illustreren duidelijk de oostwaartse beweging in de pendel. De pendel vanuit Nederlands-Limburg naar Duitsland is het meest omvangrijk (ruim 8.000 personen). Tussen 1985 en 1990 is dit aantal vrij stabiel gebleven.

De pendel vanuit België naar Nederlands Limburg is toegenomen van ruim 5.000 personen in 1985 tot 6.500 personen in 1990. Deze pendel is, gelet op de geringe pendelstroom vanuit Luik naar Nederland, waarschijnlijk vooral afkomstig van Belgisch Limburg. Volgens de van het RZI afkomstige data bedraagt de pendel van België naar Nederlands Limburg ruim 10.000 personen. Het grote verschil tussen de CBS en RZI-data illustreert het inadequate karakter van de metingen van de pendelstromen. 

De totale pendel vanuit Belgisch Limburg naar Duitsland bedroeg in 1981 volgens het Belgisch Nationaal Instituut voor de Statistiek 3.000 personen. Vanuit de provincie Luik bedroeg de pendel naar Duitsland 6.700 personen. De pendel vanuit Duitsland naar België bedraagt slechts enkele honderden personen. Volgens de secretaris van de dienst Grensarbeiders van de Confédération des Syndicats Chrétiens (CSC) in Eupen zijn er momenteel echter vanuit Belgisch Limburg hooguit 300 personen in Duitsland werkzaam en kunnen dit er nimmer 3.000 zijn geweest. Het totaal aantal Belgische pendelaars in Duitsland bedraagt volgens deze secretaris momenteel circa 3.500 à 4.000 . Volgens een opgave van het Duitse Ministerie van Financiën zijn er circa 3.400 Belgen in Duitsland werkzaam, (Finanz Min., 1990). Uit deze cijfers blijkt overigens ook dat er vanuit Duitsland circa 100 personen in België werkzaam zijn.

Rekening houdend met het feit dat de gebiedsafbakening in de bovengenoemde cijfers breder is dan die van de Euregio, kan de totale omvang van de pendelstromen binnen de Euregio MaasRijn geschat worden op 15 tot 25 duizend personen. Op een (geschatte omvang van de) beroepsbevolking van ongeveer 1,5 miljoen, betekent dit dat 1 à 2 procent van de beroepsbevolking pendelt binnen deze Euregio.

Over deze pendelaars, wie ze zijn en waar ze werken is vrij weinig bekend. Het Hoger Instituut van de Arbeid (Goethals, 1990) geeft aan dat de grensarbeiders vanuit België naar Nederland werkzaam zijn in een groot aantal verschillende sectoren: industrie en openbare nutsbedrijven, bouwmaterialen, aardewerk- en glasindustrie, electronische industrie, transportmiddelenindustrie, hotel- en restaurantwezen, handel en overige dienstverlening.

Helaas ontbreken op het niveau van de Euregio elementaire sociaal-economische statistieken en kernindicatoren ten aanzien van het functioneren van de arbeidsmarkt. De huidige arbeidsmarktcijfers zijn erg globaal en hebben of op een breder gebied betrekking of zijn onderling onvoldoende vergelijkbaar door afwijkende classificaties, meetinstrumenten en databronnen. 



\section{KNELPUNTEN RONDOM GRENSARBEID}

\subsection{TNLEIONG}

Voordat nader zal worden ingegaan op de knelpunten die zich voordoen rondom grensarbeid, is het goed om eerst eens stil te staan bij de mogelijke voordelen verbonden aan pendelarbeid. Mogelijke voordelen van grensarbeid kunnen liggen in de kleinere afstand tot het werk, een betere kwaliteit van de arbeid of betere arbeidsvoorwaarden, zoals een hogere beloning, een vaste arbeidsplaats of betere carrière- of scholingsmogelijkheden. Een bijzondere categorie pendelwerknemers ontstaat indien men vanuit voordeelsoverwegingen in het aangrenzende buitenland gaat wonen. Het voordeel kan dan onder meer ontstaan door de aantrekkelijkheid van fiscale regelingen, woon- en levenslasten en andere factoren die de woonplaatskeuze bepalen. Een bijzondere categorie pendelaars ontstaat daarnaast door "Euregionale" huwelijken.

Pendelarbeid kan ook het gevolg zijn van het ontbreken van een passende arbeidsplaats in het eigen land. Het verruimen van de blik tot over de landsgrenzen heeft het in dit geval mogelijk gemaakt werk te kunnen vinden. Een beperkt onderzoek van Goethals (1990) onder Belgische pendelaars wijst er op dat het met name de beschikbaarheid van werk is waardoor men zich gaat oriënteren op de buitenlandse arbeidsmarkt. De helft van de ondervraagden zegt een baan in België te zullen aannemen, indien die mogelijkheid zich zou voordoen. Het motief daarbij is niet alleen dat het dichterbij is, maar ook dat dan alle moeilijkheden met papieren zouden wegvallen.

\section{Knelpunten: voor wie en wanneer?}

Bij het beschrijven van knelpunten kan de pendelrichting een rol van belang spelen. De pendelstroom beweegt zich, zoals reeds werd aangegeven, globaal gezien oostwaarts. Dit is zichtbaar in de mate waarin knelpunten in eerdere studies in kaart zijn gebracht: de gevolgen van enerzijds het wonen in België en het werken in Nederland en anderzijds het pendelen van Nederland naar Duitsland zijn goed in beeld gebracht. Er zijn daarentegen geen rapporten of brochures aangetroffen waarin de nadelige gevolgen van de omgekeerde pendel worden geïnventariseerd.

Naast het onderscheid naar de pendelrichting kan het van belang zijn om bij de knelpunten een onderscheid te maken tussen de feitelijke en de potentiële pendelaars. Vanuit de vraag in hoeverre de internationale arbeidsmobiliteit binnen de Euregio wordt belemmerd, is het vooral van belang de aandacht te richten op de potentiële pendelaars. Daarbij kan men zowel denken aan werkenden als aan werklozen, herintreders en schoolverlaters. Bovendien kan men een onderscheid maken tussen degenen die op zoek zijn naar een baan (loontrekkenden) en degenen die zich als zelfstandige zouden willen vestigen.

Voor een goed overzicht van de knelpunten die kunnen optreden ten aanzien van de Euregionale arbeidsmarktmobiliteit moet echter niet alleen gekeken worden naar de potentiële pendelaars. Immers, ook vanuit de vraagkant van de arbeidsmarkt kunnen diverse factoren de mobiliteit belemmeren, als gevolg waarvan arbeidskrachten niet in de buurlanden willen of kunnen gaan werken. Daarnaast is het zinvol om de feitelijke problemen aan te geven, waarmee degenen die wel pendelen worden geconfronteerd. Tenslotte is het nuttig om te wijzen op de specifieke (informatie-)problemen waarmee 'intermediaire' organisaties, die een rol kunnen spelen bij de afstemming van vraag en aanbod op de arbeidsmarkt, worden geconfronteerd. Overigens moet worden opgemerkt dat een aantal knelpunten een enigszins subjectief karakter heeft. Zo zal éénzelfde regeling niet voor alle betrokkenen tot dezelfde 'knelpuntsituaties' leiden. 
Aan het eind van dit hoofdstuk wordt in schema 1 een globaal overzicht gegeven van de belangrijkste knelpunten zoals die worden ervaren door de in dit rapport onderscheiden doelgroepen. De belangrijkste knelpunten zijn daarbij ingedeeld in de vier in hoofdstuk 1 genoemde themagebieden: arbeidsmarkt, onderwijs en scholing, fiscus en financiën en sociale zekerheid en pensioenen. Daarnaast worden nog de knelpunten aangeduid die zich voordoen op het infrastructurele vlak, e.d. De verdere opzet van dit hoofdstuk is als volgt. In paragraaf 3.2. worden de knelpunten aangegeven die zich voordoen in de dataverzameling en informatievoorziening, waarna in paragraaf 3.3. de in schema 1 globaal aangeduide knelpunten meer uitvoerig zullen worden besproken. Daarbij wordt achtereenvolgens ingegaan op de bovengenoemde vier themagebieden.

\subsection{KNELPUNTEN IN DE DATAVERZAMELING EN WFORMATEVOORZIENING}

\section{Behoefte aan informatie m.b.t. knelpunten en mogelijkheden op de arbeidsmarkt}

Zoals in hoofdstuk 2 reeds werd aangegeven, bestaat er een groot gebrek aan informatie over de omvang, herkomst, samenstelling en bestemming van pendelarbeid in de Euregio Maas-Rijn. Statistisch materiaal over de Euregionale arbeidsmarkt is niet alleen van belang voor beleidsontwikkeling door de verschillende overheden en een efficiënte bemiddeling door arbeidsvoorzieningsorganisaties, maar ook voor het bedrijfsleven. Uit een recent onderzoek van KPMG, Klynveld Management Consultants (KPMG, 1991) blijkt dat Limburgse bedrijven, in het bijzonder in de produktiesector, behoefte hebben aan (Eu)regionale arbeidsmarktinformatie. Dit signaal wordt veelal onderschreven in de gesprekken die zijn gevoerd met hoofden personeelszaken van bedrijven en personen werkzaam in de sfeer van arbeidsvoorziening en personeelsbemiddeling.

Daarbij gaat het bijvoorbeeld om de vraag-aanbod verhoudingen op de arbeidsmarkt en salarisgegevens per sector, beroep, opleiding en subregio. Voor bedrijven zouden deze gegevens gebruikt kunnen worden voor het personeelsbeleid op (sub)regionaal niveau in het algemeen en de personeelswerving, het beloningsbeleid en het eventuele outplacementbeleid in het bijzonder. Voor de arbeidsvoorzieningsorganisaties is een gedetailleerd doch overzichtelijk inzicht in de vraag-aanbod verhouding in de aanliggende grensregio's van belang. Met name wanneer deze vraag-aanbod verhoudingen in kwalitatief of kwantitatief opzicht wezenlijk afwijken van die in de eigen regio is verder onderzoek naar specifieke vacatures en/of aanvullende scholingsmogelijkheden van groot belang.

\section{Behoefte aan informatie m.b.t. mobiliteitsbelemmerende factoren}

Uit de gevoerde gesprekken bij enkele relatief grote bedrijven die reeds gebruik maken van pendelarbeid, blijkt dat men geen extra ondersteuning nodig zegt te hebben bij de werving, aanstelling en begeleiding van buitenlandse grensarbeiders. Dankzij ervaring, de kennis die aanwezig is bij reeds werkzame grensarbeiders en de capaciteit die grotere bedrijven hebben om snel de benodigde informatie te achterhalen bij de desbetreffende instanties, doen zich, voor deze bedrijven althans, niet al te veel problemen voor. Uit gesprekken die vervolgens met de werknemers/pendelaars zijn gevoerd blijkt overigens dat de informatieverstrekking van bedrijven aan pendelende werknemers doorgaans nog sterk tekortschiet. 
In het kader van een grote reorganisatie is begin 1991 een complete afdeling van Philips Eindhoven met circa 50 werknemers (Nederlanders en Belgen) overgeplaatst naar Aken in Duitstand. Na herhaalde verzoeken van de werknemers werd door de Afdeling Personeelszaken van het Nederlands bedrif voor de overplaatsing een voorlichtingsavend georganiseerd met Sprekers van verschillende Nederlandse en Duitse instanties, waaronder de Duitse Krankenkasse, het Zlekenfonds Venlo, de Duitse belastingdienst. het Duitse staatspensioenfonds en de Dienst Personeelszaken van de betreffende butenlandse bedijfsvestiging. Deze voorlichtingsavond maakte volgens de werkremers eèn ding duidelijk en wel dat de gevolgen erg gecompliceerd waren en bovendien afhankelikk zouden zijh van leders individuele situatio en voorkeuren. Daardeor konden er nawwelikss algemene richtlingen worden gegeven. De tijdens het groepsgesprek door ons getoonde brochures van bijvoorbeeld de Vereniging Europese Grenslandbewoners VEG). Algemeen Christeljk Vakverbond (ACY) of de Bureaus voor Belgische- en Duitse Zaken waren onbekend en bleken in een grote intormatiebehoefte te voorzien.

Hieruit zouden verschillende conclusies kunnen worden getrokken:

- . de informatieavond leidde tot verwaring en een toegenomen weerstand tegen de opgelegde bedrijsverplaatsing. Door een riante pendelvergoeding voor de eerste laren werd deze weerstand gedeelteljk weggenomen:

zelts een grote. internationaal opererende onderneming is blikbaar niet op de hoogte van de meest relevante voorlichtingsorganisaties en het beschikbare informatiemateriaal.

de uitgenodigde instanties zin vooral betrokken bij de uitvoering van de regelgeving en daardoor in zekere zin belanghebbenden. Deze organisaties zin ochter doorgaans nauwelijks ingesteld op informatieverstrekking en hebben derhalve niet of nauweliks de beschikking over begrijpelijke en op de informatiebehoefte van (potentiele) pendelaars afgestemde brochures;

Bovenstaande waarnemingen worden onderschreven door het volgende: In de Banenkrant, een bijlage van het huisaan-huis advertentieblad "Zondagnieuws", van 5 oktober j1. stond een interview met een vertegenwoordiger van de Vereniging van Europese Grenslandbewoners (VEG). Binnen drie dagen had deze VEG-vertegenwoordiger meer dan 20 verzoeken om informatie gekregen, hoewel in het interview alleen voor- en achternaam en woonplaats vermeld werden.

Het vermoeden lijkt gerechtvaardigd te zijn dat het vooral het Midden- en Klein bedrijf en de zelfstandigen zijn, die het vaak ontbreekt aan specifieke deskundigheid met betrekking tot de knelpunten en mogelijkheden van het aanstellen van werknemers uit buurlanden.

Het ontbreken van specifieke deskundigheid geldt nog sterker voor de (potentiële) pendelaar. Verwacht mag worden dat het overgrote deel van de beroepsbevolking in de Euregio weliswaar direct of indirect bekend is met het fenomeen pendelarbeid. Er is echter maar een zeer beperkt aantal deskundigen dat bekend is met alle mogelijke fiscale- en sociaal-rechtelijke gevolgen die daarmee verbonden kunnen zijn.

Ten aanzien van het beschikbare schriftelijke informatiemateriaal over de fiscale- en sociaaljuridische gevolgen van pendelarbeid kan het volgende worden geconcludeerd:

- er is relatief veel schriftelijke informatie beschikbaar over de belangrijkste fiscale- en sociaaljuridische gevolgen van de pendelarbeid van België naar Nederland of Duitsland en van Nederland naar Duitsland. Deze informatie is echter op relatief weinig plaatsen verkrijgbaar. Bovendien is dit materiaal in de meeste gevallen opgesteld ten behoeve van intern, ambtelijk gebruik of direct samengesteld op basis van ambtelijke stukken, waardoor het materiaal niet erg geschikt is voor het geven voorlichting. Een uitzondering moet hierbij gemaakt worden voor de door het Benelux-bureau samengestelde brochures voor Nederlandse- en Belgische pendelaars, en voor de Vlaamse ACV en de Waalse CSC die voor de Belgische pendelaars naar Nederland en Duitsland zeer handzame brochures hebben samengesteld. De Vereniging Europese Grenslandbewoners (VEG) verstrekt zeer toegankelijke informatie voor Nederlandse pendelaars naar Duitsland; 

- er is nauwelijks schriftelijke informatie beschikbaar over de gevolgen van het wonen in Duitsland en het werken in België of Nederland; en er is relatief weinig informatie beschikbaar over het wonen in Nederland en het werken in België;

- de beschikbare schriftelijke informatie beperkt zich veelal tot een (gebruikersonvriendelijke) vergelijking van de fiscale en sociaal-rechtelijke regelingen. Van 'information mapping', dat wil zeggen het 'menugewijs' aanbieden van korte 'informatieblokken', wordt nog geen gebruik gemaakt;

- er lijkt sprake te zijn van gescheiden circuits van informatieverstrekking vanuit een aantal verschillende betrokken instanties: vakbonden, arbeidsvoorziening en particuliere initiatieven. Een dergelijke verbrokkeling maakt het enerzijds onduidelijk waar men voor een bepaalde informatievraag het beste terecht kan en belemmert anderzijds een geïntegreerd voorlichtingsbeleid.

Een ambtenaar van het Ministerie van Sociale Zaken en Werkgelegenheid merkte hierover op: Als er één ding is waarmee le op korte termin kunt scoren dan is het wel de voorlichting. Die is nog erg divers en versnipperd langs de grenzen. Eche deskundigheid is bovendien erg schaars'

\subsection{KNELPUNTEN NAAR THEMACEBIED}

\subsubsection{Arbeidsmarkt}

Baanzoekende werknemers oriënteren zich op hun arbeidsmarktmogelijkheden op basis van een scala aan mogelijke informatiebronnen, variërend van radio, t.v. en dagbladen, personeelsadvertenties in de lokale media, directe informatie van werkgevers, de arbeidsbureaus en de particuliere arbeidsbemiddelings- en uitzendbureaus. Ook het 'van-horen-zeggen-circuit' speelt bij deze oriëntatie een belangrijke rol.

Voor werkgevers is kennis van de relevante lokale en regionale arbeidsmarktsegmenten van groot belang voor een effectieve personeelswerving. Daarvoor staan min of meer dezelfde publieke informatiebronnen ter beschikking als voor de baanzoekende werknemer, zij het dat verwacht mag worden dat werkgevers deze informatiebronnen vaker en op een meer intensieve en meer professionele wijze zullen gebruiken. In de grensstreken blijkt het aantal mogelijke instrumenten om zich te oriënteren op de arbeidsmarktmogelijkheden 'over de grens', echter beperkt te zijn. De grens blijkt daarnaast niet alleen nog als een fysieke kering te fungeren voor de informatiedragers (lokale media, het kennissen-circuit) maar ook voor de begrijpelijkheid van de informatie (omschrijving van de vacature, kwalificatie-eisen, e.d.).

In het verleden hebben werkgevers in bijvoorbeeld de bouw en de industrie op deze problemen een antwoord gevonden door een actief recruteringsbeleid over de grens te voeren. Met zittingsdagen in het plaatselijke café en door een fiks handgeld ter beschikking te stellen, werden de benodigde arbeidskrachten geronseld. Tegenwoordig is echter het scala aan beroepen, beroepskwalificaties, opleidingen en getuigschriften aanzienlijk toegenomen. Bovendien zijn de allocatiemechanismen en -procedures tussen vraag en aanbod op de arbeidsmarkt in veel gevallen formeler en complexer geworden.

Ondanks de sterk toegenomen complexiteit van de grensoverschrijdende personeelswerving, arbeidsbemiddeling en sollicitatiemogelijkheden, zijn de daarvoor benodigde informatiemogelijkheden zeer gering gebleven. Daarbij dient opgemerkt te worden dat de motivatie voor de werknemer om zich over de grens te oriënteren op een mogelijke baan, in de loop der jaren is 
afgenomen, ongetwijfeld mede omdat het stelsel van fiscus en sociale zekerheid steeds ingewikkelder is geworden. Met uitzondering van een kleine groep pendelaars, voor wie het desondanks financieel aantrekkelijk is om over de grens te werken, is het echter voor het merendeel van zowel werkgevers, als werknemers, vooral uit noodzaak wanneer men in het nabije buitenland gaat werven of solliciteren.

Belemmeringen die een kwantitatief inzicht in de arbeidsmarktsituatie in de aangrenzende regio's in de weg staan, liggen in het ontbreken van een uniforme en gedetailleerde verzameling van arbeidsmarktgegevens. Daarvoor is de ontwikkeling van een uniform coderings- en classificatiesysteem voor bedrijven, beroepen en opleidingen noodzakelijk. De door het International Labour Office (ILO) ontwikkelde standaardclassificaties zijn weliswaar sterk verouderd doch kunnen hiervoor wel als basis dienen.

Welke problemen komen de individuele, personeelzoekende werkgever en de in het nabije buitenland wonende, baanzoekende (potentiële) werknemer tegen, indien zij naar elkaar op zoek zijn? Voor het beantwoorden van deze vraag is het nuttig de mogelijk belemmerde factoren in te delen naar een drietal fasen waarin het allocatieproces op de arbeidsmarkt kan worden opgedeeld:

\section{Oriëntatiefase:}

- werknemers zijn onvoldoende op de hoogte van de inhoud van de voor hen interessante vacatures in de aangrenzende regio's;

- met name het midden- en kleinbedrijf is onbekend met de aard van de aangeboden kwalificaties in de buurlanden;

- werkgevers en werknemers zijn niet exact op de hoogte van de lokale arbeidsmarktsituatie 'over de grens'.

\section{Zoekfase:}

- verspreidingsgebied van lokale kranten kent vrij strikte begrenzing;

- bij werkgevers ontbreekt de kennis over advertentiemogelijkheden (adres, contactpersonen, tarieven) en het te verwachten rendement in media in het aangrenzende buitenland;

- media zijn huiverig om advertenties van onbekende, buitenlandse adverteerders op te nemen: veelal is contante betaling verplicht.

\section{Contactfase:}

- werkgevers kunnen de aangeboden kwalificaties van buitenlandse referenten niet op hun juiste waarde schatten.

Overigens moet worden opgemerkt dat literatuur of empirische gegevens over personeelswerving en solliciteren over de grens tot op heden ontbreekt. In het recente rapport 'Trends en ontwikkelingen in Human Resource Management in Limburg', van KPMG Klynveld Management Consultants (KPMG 1991) komt dit aspect nauwelijks aan de orde. Wel wordt in dit rapport gewag gemaakt van de grote behoefte bij bedrijven uit de industrie en de produktiesector aan vergelijkbare salarisgegevens voor het technisch personeel.

In een recentelijk afgesloten onderzoek van het Nederlands Economisch Instituut (NEI) in opdracht van het Centraal Bureau voor de Arbeidsvoorziening (CBA, 1991) naar de internationale arbeidsbemiddeling komen de onderzoekers tot de conclusie dat de bestaande pendelarbeid voomamelijk tot stand is gekomen door een aktie van een werkgever of een werknemer. De Nederlandse overheidsdiensten en arbeidsvoorzieningsorganisaties spelen bij het bevorderen van een vrij verkeer van werknemers slechts een geringe rol. Hoewel de arbeldsbureaus in de grensstreek daarentegen wel grensoverschijdende activiteiten ontwikkelen. bijkt van een gestructureerde vorm van samenwerking nog nauwelijks sprake te zijn. 
De arbeidsbemiddeling aan weerszijden van de grens heeft veelal plaats door middel van grensoverschrijdende contacten en uitwisseling van informatie. Deze informatie-uitwisseling blijkt op enkele plaatsen redelijk succesvol te zijn. De geautomatiseerde vacature-uitwisseling tussen arbeidsbureaus via de uitwisselingsprogramma's SEDOC en JET verloopt daarentegen nog steeds stroef. Problemen doen zich onder meer voor omdat de nationale stelsels van vacatureregistratie onderling niet compatibel zijn. Hierdoor moeten de buitenlandse vacatures steeds opnieuw handmatig ingevoerd worden. Bovendien lijkt de 'trefkans' voor een geslaagde bemiddeling beperkt te zijn, indien niet ook inzicht wordt gegeven in de vraag-aanbod verhoudingen aan de andere zijde van de grens. Een derde belemmering is het ontbreken van een toegankelijk informatiesysteem voor de diplomavergelijking. De behoefte aan een dergelijk informatiesysteem zal zich voordoen bij een grootschalige geautomatiseerde vacatureuitwisseling.

Eind 1990 werd de meubelfabriek Ervie Polstermöbel uit het Duitse Erkelens. circa 40 kilometer van Sittard, geconfronteerd met de mogelijkheid van een grote order. Daardoor zou er op korte termijn een groot aantal ongeschoolde vakkrachten nodig zijn. Het Arbeitsamt Erkelens kon hiervoor in de direkte ongeving niet genoeg mensen krijgen. Een bemiddelaar van het Arbeidsbureau Sittard kwam dit min of neer toevallig ter ore. Deze nam contact op met het Arbeitsamt Erkelens en het meubeibedrif en had vervolgens in korte tijd een 25 -tal geïnteresseerden gevonden. Voor het vervoer werd een busdienst ingesteld. Op het laatste moment werd de actie echter vanuit het bedriff afgeblazen de order was niet doorgegaan. Begin 1991 werd het Arbeidsbureau Sittard benaderd door een zakenman uit Geleen. Deze wilde in een tabriekshal in Geleen een bedrif opzetten voor de preparatie van armaturen voor leren bankstelten. De afwerking zou plaats vinden bij Ervie Postermöbel in Erkelens die inmiddels toch weer om personeelsleden verlegen leek te zitten. Het plan van de Geleense zakenman bleek echter niet haalbaar: aan de grens zou per bankstel een dermate hoge borgsom aan de douane betaald moeten worden dat dit bedrijseconomisch niet verantwoord was. Niettemin zou er een gesprek plaatsvinden tussen de nieuwe bedrijfsleider van Polstermöbel, het Arbeitsamt Erkelens en het Arbeidsbureau Sittard. Eerstgenoemden kwamen daar echter niet opdagen. Volgens het Arbeitsamt Erkelens omdat men door bedrijssorganisatorische maatregelen met minder mensen kon volstaan. Volgens de nieuwe bedriffsleider omdat er vanuit Nedertand nauwelijks reacties waren gekomen op een wervingsadvertentie.

\subsubsection{Onderwijs en scholing}

Een in het provinciaal onderwijsbeleid uitstekend ingewijde deskundige maakte melding van het grote aantal Limburgse jongeren uit Nederlands Limburg dat nu reeds om 'kwaliteitsredenen' een reguliere opleiding in Beigie bezoekt. Zo zou de Heilig Hartschool te Maasmechelen (B) momenteel bezocht worden door circa 400 Nederlandse jongeren.

Hoewel grensbewoners volgens het Verdrag van Rome niet geweigerd kunnen worden tot een (beroeps)opleiding in een naburig EG-land is er nog een groot aantal factoren waardoor het volgen van een opleiding over de grens wordt bemoeilijkt. Een tweetal knelpunten staat daarbij centraal:

- er is geen afstemming van de opleiding op de behoeften aan de andere kant van de grens;

- men heeft geen toegang tot de onderwijsstelsels in de buurlanden.

Bovendien ontbreekt het nog aan een toegankelijk overzicht van de vraag naar en het aanbod van opleidings- en scholingsmogelijkheden en de daarvoor geldende vooropleidingseisen. Ook doet zich een omvangrijk probleem voor op het gebied van de erkenning van diploma's, al bestaat er thans wel een algemene richtlijn voor de erkenning van hoger-onderwijsdiploma's (universitaire- en beroepsopleidingen van tenminste drie jaar). 
In Nederland heett de organisatie van de diplomavergelijking overigens een enigszins versnipperd karakser doordat verschillende instanties bij de uitvoering hiervan zïn betrokken de sectie studievergelijking van het NuFFIC, de Intormatiseringsbank te Groningen, het Ministerie van Economische Zaken (in het kader van de vestigingswetgeving) en het Centraal Bureau voor de Arbeidsvoorziening (CBA) (In verband met de arbeldsbemideleling en scholingsactiviteiten).

Een deskundige maakte melding van de nieuwbouw, van een opleidingscentrum voor CNC installaties in Nederland. Het betrof een zeer omvangrijke investering. Niet lang daarna bleek dat er omstreeks dezelfde tijd enkele tientallen kllometers over de grens eveneens een nieuw en praktisch vergelikbaar opleidingscentrum was neergezet.

Ook wordt door CEDEFOP, Berlijn nog gewerkt aan de vergelijkbaarheid van getuigschriften van vakbekwaamheid van onder andere het leerlingwezen. Hoewel het punt van diploma-vergelijking en getuigschriften vaak genoemd wordt als een belangrijk knelpunt voor grensoverschrijdende arbeid, wordt dit niet onderschreven door degenen waarmee door ons is gesproken: noch de pendelaars zelf, noch de (grotere) bedrijven zeggen hiermee veel last te hebben (gehad). Niettemin zou het een belangrijk obstakel kunnen vormen voor potentiële pendelaars en hun mogelijke werkgevers (met name voor het midden- en kleinbedrijf en zelfstandigen).

\subsubsection{Fiscus en financiën}

Op Europees niveau spelen op het terrein van de persoonlijke belastingheffing twee kwesties een belangrijke rol. Ten eerste, de competentie-kwestie tussen de Europese Commissie enerzijds en de Raad van Ministers en nationale overheden anderzijds. De Commissie heeft in het verleden verschillende malen getracht om op het terrein van de direkte, persoonlijke belastingen, via een voorstel voor een Richtlijn of Verordening op te treden. Tot op heden hebben de nationale overheden dit echter kunnen tegenhouden, onder verwijzing naar het Europees Verdrag waarin de soevereiniteit van de lidstaten op het terrein van de direkte belastingheffing, wordt erkend. Als gevolg van de gestage ontwikkeling van het Europees Gemeenschapsrecht waarbij de jurisprudentie een belangrijke rol speelt, ontkwamen de Commissie en de lidstaten echter niet aan een voortdurende herbezinning over de taakverdeling op het terrein van direkte belastingheffing. Sinds kort is dit echter een officieel taakgebied van de Europese Commissie, zodat gewerkt zou kunnen gaan worden aan coördinerende wet- en regelgeving.

Ten tweede speelt de kwestie of de (persoonlijke) belastingheffing plaats dient te vinden in het woonland of in het werkland. Het woonland, dat volgens de algemene rechtsbeginselen het belastingrecht heeft, heeft bij pendelaars echter niet de mogelijkheid om de loon- of inkomstenbelasting aan de bron op te leggen. In het algemeen wordt er daarentegen thans wel in het werkland een belasting op het inkomen geheven. Het belastingverdrag tussen België en Nederland is hierop een uitzondering.

In 1979 is door de Europese Commissie een voorstel voor een Belasting-Richtlijn ingediend. Hierin wordt voorgesteld om de inkomsten van grensarbeiders te belasten in het woonland. Indien in het werkland belastingheffing aan de bron plaatsvindt dient een verrekening met het woonland plaats te vinden. Het voorstel is echter vanaf 1986 in de Raad van Ministers geblokkeerd, omdat de meeste lidstaten van mening zijn dat dit probleem geregeld moet worden aan de hand van bilaterale verdragen. Het zijn met name de grotere landen zoals Duitsland en Frankrijk die zich tegen de voorgestelde Richtlijn verzetten omdat dit voor hen een groot inkomensverlies zou betekenen. Met de inkomstenbelasting van bijvoorbeeld Nederlandse pendelaars in Duitsland is 
volgens een schatting van het Duitse Ministerie van Financiën een bedrag van 100 miljoen DM. gemoeid (Finanz Min.,1990). Daarnaast zijn er enkele regionale vakverenigingen die zich tegen het voorstel verzetten.

Als gevolg van deze patstelling op Europees niveau is de Commissie genoodzaakt tot het ontwikkelen van een nieuwe Belasting-Richtlijn voor de lidstaten. Tot die tijd zullen de verschillen in uitgangspunten en de achterstelling van pendelaars in de nationale belastingwetten waarschijnlijk blijven voortbestaan. De commissie heeft tot die tijd alleen de mogelijkheid om inbreukprocedures in te stellen tegen lidstaten die pendelaars benadelen ten opzichte van eigen ingezetenen. Voor pendelaars bestaat de mogelijkheid om deze gelijkheid af te dwingen door juridische procedures tot aan het Europese Hof van Justitie. De juridische mogelijkheden hiervoor zijn in ieder geval aanzienlijk toegenomen nu het Hof via een recent arrest (8 mei 1990, zaak $175 / 88$ ) heeft vastgelegd dat het beginsel van gelijke behandeling ook geldt voor de inkomstenbelasting. Blijft wel dat een individuele pendelaar over een groot uithoudingsvermogen en zelfvertrouwen moet beschikken, om een dergelijk juridisch proces tot het eind toe te doorlopen.

Voor een goed overzicht van de problemen die zich voordoen op het terrein van de fiscale wetgeving bij de belangrijkste bestaande pendelstromen zal achtereenvolgens worden ingegaan op de pendelstromen van Nederland naar Duitsland, van België naar Nederland en van België naar Duitsland. Daarna wordt kort ingegaan op specifieke knelpunten in het betalingsverkeer.

\section{Specifieke fiscale problemen tussen Duitsland en Nederland}

Het Duits-Nederlandse Verdrag van 1959 wijst het heffingsrecht toe aan het werkland. Het Verdrag bevat geen afzonderlijke regelingen voor grenspendelaars. Nederland verleent, als woonland van de Nederlandse pendelaars in Duitsland, ter voorkoming van dubbele belasting een vrijstelling van het betalen van inkomstenbelasting over het Duitse inkomen. In het Aanvullend Protocol uit 1980 (op het Verdrag van 1959) is de werkstaatheffing aangevuld met een aantal bepalingen waardoor pendelaars voor dezelfde tegemoetkomingen in aanmerking komen als de inwoners van het werkland.

De voorwaarde daarvoor is echter dat de inkomsten waarover de werkstaat het recht tot belastingheffing heeft ten minste $90 \%$ bedragen van het gezinsinkomen van de grensarbeider. Hoewel de fiscale positie van de grensarbeider aanzienlijk verbeterd is door dit Aanvullend Protocol, ondervinden grensarbeiders die in Nederland wonen en in Duitsland werken nog steeds een aantal benadelingen (Euregio, 1989).

Deze problemen concentreren zich rondom de volgende punten:

- benadelingen in Nederland voor werknemers in Duitsland die in Nederland wonen. Zo zijn er voor alleenstaande ouders problemen met betrekking tot de belastbaarheid van de kinderbijslag en ondervinden alleenstaanden problemen bij de aftrekbaarheid van de oudedagsvoorziening;

- benadelingen in Duitsland voor werknemers in Duitsland die in Nederland wonen. Problemen doen zich hierbij onder meer voor bij de aftrekbaarheid van hypotheekrente. Ook de indeling in tariefgroepen veroorzaakt problemen. Zo komen de part-time pendelaar, de pendelaar met bijverdiensten in het woonland, alsmede degene die niet het gehele jaar als pendelaar heeft gewerkt, automatisch in de hoogste Steuerklasse terecht. De genoemde personen komen tevens niet in aanmerking voor de 'Lohnsteuer-Jahresausgleich', zij kunnen de Vorsorgeauswendungen niet voor de feitelijke hoogte opvoeren en kunnen tevens geen 'aussergewöhnliche Belastungen' of giften en bijdragen aftrekken;

- benadelingen voor zelfstandigen die in Nederland wonen en in Duitsland werkzaam zijn. Deze worden altijd in de hoogste Steuerklasse ingedeeld en kunnen voor de inkomstenbelasting van geen enkele aftrekpost gebruik maken. 

Overigens heeft het Duitse Ministerie van Financiën inmiddels aan de Duitse Bondsdag voorgesteld om het Duits-Nederlandse belastingverdrag als voorbeeld te nemen voor andere door Duitsland af te sluiten bilaterale belastingverdragen. Nederland heeft daarentegen enkele jaren geleden aan Duitsland voorgesteld om, analoog aan het belastingverdrag tussen Nederland en België, de belastingheffing over de inkomsten van grensarbeiders toe te wijzen aan de woonstaat (FEM, 1989). De Bondsrepubliek Duitsland zou daar echter om budgettaire redenen niets voor voelen. De deelstaat Nordrhein-Westfalen heeft zich niet alleen om financiële redenen, maar ook vanwege de uitvoeringsgevolgen - loskoppeling van de heffing van sociale premies en de inkomstenbelasting - tegen het voorstel uitgesproken. Vervolgens heeft Nederland zijn voorstel aangepast, in die zin dat het beginsel van de woonstaatheffing gehandhaafd blijt maar dat de belastingopbrengst over inkomen van de grensarbeider wordt verdeeld tussen Nederland en Duitsland. Daarmee lijkt dit voorstel sterk op de voorgestelde Belasting-Richtlijn van de Europese Commissie. De onderhandelingen met Duitsland over de voorstellen voor het bilaterale belastingverdrag zijn door Duitsland voor onbepaalde tijd vooruit geschoven aangezien men voorrang wenst te geven aan de fiscale integratie van de voormalige DDR in de Bondsrepubliek Duitsland.

\section{Specifieke fiscale problemen tussen Nederland en België}

In het uit 1970 daterende belastingverdrag tussen Nederland en België is overeengekomen dat het heffingsrecht over het arbeidsinkomen van de grensarbeiders in beginsel toekomt aan de woonland. Enkele knelpunten die zich in de jaren daarna manifesteerden werden via ministeriële resoluties opgelost. Dit verdrag wordt vrij unaniem als bevredigend beschouwd. Niettemin blijven er ten aanzien van de uitvoering van het verdrag nog knelpunten bestaan. Zo zijn de (ex-) werknemers verantwoordelijk gesteld voor het twee-jaarlijks aanvragen en verkrijgen van de Beschikking Vrijstelling Loonbelasting ('grensarbeidersverklaring'), zodat de werkgever en uitkerende instanties zoals bedrijfsverenigingen en pensioenfondsen geen loon- of inkomstenbelasting hoeven in te houden. Het blijkt in de praktijk echter veelvuldig voor te komen dat deze verklaring niet tijdig wordt aangevraagd of verstrekt. In dat geval zal er wel inhouding van het werkgeversdeel van de inkomstenbelasting plaatsvinden. Deze zal dan achteraf, indien de pendelaar daar weet van krijgt, teruggevorderd moeten worden bij de Nederlandse belastingdienst. Dit was tot voor kort een omslachtige en langdurige operatie waarbij bovendien renteverlies wordt geleden.

De heer M. is woonachtig in de Belgische Voerstreek en sedert 1977 werkzaam als internationaal chauffeur bij een Nederlandse transportonderneming in Maastricht. Hij heeft indertijd op advies van zijn werkgever een grensarbeiderverklaring ingevuld en deze steeds laten veriengen. Hij werd hierdoor, volgens het BelgischNederlandse beslatingverdrag vrijgesteld van belastingheffing in Nederland ten gunste van België. Nu zijn de werkgever en de Nederlandse belastingdienst echter tot de ontdekking gekomen dat het verdrag niet op M. van toepassing is, aangezien hij als internationaal chauffeur het grootste deel van zijn werktijd niet in de grensstreek werkzaam is. De Nederlandse belastingdienst beraadt zich nu of tot heffing met terugwerkende kracht moet worden overgegaan.

In januari 1991 heeft er in Nederland een centralisatie plaats gevonden van alle 'buitenlandse' belastingzaken bij de Belastingdienst in Brunssum. Er is nu echter een nogal gecompliceerde vragenlijst opgesteld, voor terugvorderingen op grond van verdragen en nationale sociale wetgeving, die geldt voor de grensarbeiders waarop de grensarbeidersverklaring (model 90-A) van toepassing is. 

Bovengenoemde terugvorderingsproblematiek doet zich nog veel vaker voor bij de uitkeringen door bedrijfsverenigingen, pensioenfondsen, VUT-fondsen, e.d. Ook hier vindt er invordering van loonbelasting plaats in het voormalige werkland. Dit zou echter voorkomen kunnen worden indien het uitkeringsorgaan de beschikking heeft over een 'Beschikking Vrijstelling Loonbelasting', dat wil zeggen een toestemming van de belastinginspecteur om de loonbelasting niet in te houden, maar uit te keren aan de pendelaar, zodat deze vervolgens aan de Belgische belastingdienst belasting kan afdragen.

\section{Specifieke fiscale problemen tussen België en Duitsland}

Ook tussen Duitsland en België bestaat een belastingverdrag. Hierin is het woonland gerechtigd tot belastingheffing, echter alleen voorzover het grenspendelaars betreft. Deze dienen volgens het verdrag binnen een gebied van $20 \mathrm{~km}$. van de grens woonachtig én werkzaam te zijn. Overigens geldt voor Belgen die werkzaam zijn in Duitse overheidsdienst, dat men in Duitsland inkomstenbelasting dient af te dragen. Volgens een nota van het Duitse Ministerie van Financiën (Finanz Min., 1990) hebben zowel de Duitse als de Belgische pendelaars overigens een voorkeur voor belastingheffing in Duitsland aangezien die lager is. België heeft voorgesteld om een eventuele overgang naar belastingheffing in het werkland in een breed opgezet belastingakkoord te regelen.

\section{Knelpunten in het betalingsverkeer: wisselkoersen en banktransacties}

Indien salarissen, pensioenen e.d. op een rekening in het (voormalige) werkland gestort worden, moeten pendelaars dit in contanten opnemen om het vervolgens over de grens te brengen en in eigen land weer te kunnen omwisselen tegen een doorgaans ongunstige wisselkoers. Mogelijke problemen doen zich, naast een riskant deviezentransport, in dit verband vooral voor bij schommelingen in wisselkoersen en vanwege de door banken gehanteerde relatief hoge tarieven voor grensoverschrijdend betalingsverkeer. Deze hoge tarieven zijn het gevolg van het feit dat internationale girale overboekingen nog steeds handmatig worden uitgevoerd. Voor de bestedingsmogelijkheden van de salarisrekening in het werkland zijn de ontwikkelingen op het gebied van betaalkaarten en betaalautomaten van belang. Deze zullen op den duur het Eurocheque- en de daarmee vergelijkbare stelsels gaan vervangen.

Een in de Belgische grensstreek woonachtige Nederlander met een Nederlandse Postgirorekening diende op korte termijn een verzekeringspremie te voldoen en naakte daarvoor een (kiein) geldbedrag over naar een Nedertandse Bank. Deze bracht daarvoor $f$ 15,- in mindering op het overgemaakte bedrag, hoewel ef geen vreemde vatutatransactie had plaats gevonden. Hierdoor was de premie nog niet voldaan op het moment dat de verzekering diende in te gaan.

\subsubsection{Sociale zekerheid en pensioenen}

De sociale verzekeringspositie van pendelaars wordt voor een belangrijk deel geregeld in EGVerordening $\mathrm{nr}$. 1408/71. Volgens deze Verordening is een grensarbeider slechts aan de wetgeving van één enkele lidstaat onderworpen. In beginsel is de grensarbeider voor wat betreft de verplichting van verzekering en premiebetaling onderworpen aan de wettelijke voorschriften van het land waar hij of zij werkt. De problemen waarmee de grensarbeiders desalniettemin te kampen hebben, vloeien voort uit de verschillende uitgangspunten van de nationale stelsels van sociale zekerheid. Ook leiden interpretatieverschillen van de bestaande bilaterale verdragen tot problemen. 

Verschillende deskundigen, waarmee in het kader van het onderzoek is gesproken, zijn van mening dat een harmonisatie van de nationale stelsels van sociale zekerheid in de komende decennia niet is te verwachten. Daarvoor lopen de welvaartsverschillen tussen bijvoorbeeld Portugal en Nederland teveel uiteen. Er wordt veeleer gestreefd naar een coördinatie van regelgeving en wetgeving en er worden, waar mogelijk, initiatieven ontwikkeld om te komen tot convergentie, dat wil zeggen het op termijn zoveel mogelijk naar elkaar doen toegroeien van de stelsels. Wel moet men bedenken dat dit uiteindelijk op het terrein ligt van de soevereine lidstaten. Het Gemeenschapshandvest van sociale grondrechten geeft de Europese Commissie de bevoegdheid om coördinerende richtlijnen te ontwikkelen om de ongewenste gevolgen van grensoverschrijdende toepassing van de sociale zekerheidsstelsels weg te nemen.

Op nationaal niveau kunnen convergentie en coördinatie tot stand worden gebracht op basis van bilaterale verdragen en door middel van wijzigingen in de nationale wetgeving. De snelste niettemin evenzeer moeizame weg, om tot coördinatie te komen ligt echter in het ontwikkelen van jurisprudentie door middel van tot op Europees niveau uitgevochten procedures. De hieruit voortkomende uitspraken gelden immers voor alle EG-landen en staan boven de nationale wetgeving.

Binnen het thema van de sociale zekerheid wordt een aparte positie ingenomen door de aanvullende pensioenen (ABP, 1991). Het is in vrijwel de gehele Europese Gemeenschap gebruikelijk dat er in de opbouw van pensioenen sprake is van een driedeling:

- een basislaag, geregeld via sociale verzekeringen;

- een aanvullende laag, per bedrijf of bedrijfstak opgezet;

- een toplaag, individueel in te vullen, meestal bij een verzekeringsmaatschappij.

In Duitsland en België is de basislaag veel belangrijker voor het inkomen van de gepensioneerden, dan in Nederland, waar de aanvullende laag erg belangrijk is. Om op het terrein van de aanvullende pensioenen binnen de EG een assimilatie te bereiken is eerst het naar elkaar toegroeien van de basisregelingen noodzakelijk. Het zal echter nog geruime tijd duren voordat dit tot stand zal zijn gebracht.

Ook ten aanzien van de ziektekostenverzekering worden grensarbeiders met problemen geconfronteerd. In de regel wordt een grensarbeider medisch behandeld in het land waarin deze woont. Dit geldt ook voor gezinsleden van de pendelaar. Pendelaars kunnen zich daarnaast ook laten behandelen in het werkland. Voor de gezinsleden van de grensarbeiders is dit echter alleen mogelijk indien er sprake is van een spoedgeval of een verdrag tot samenwerking tussen de bevoegde instanties. De Europese Commissie overweegt om deze beperkende voorwaarden af te schaffen, zodat de gezinnen van grensarbeiders de vrije keuze wordt gelaten. 'Dit zou niet alleen een verlichting zijn voor de betrokken personen maar zou ook een aansporing vormen tot het optimaal gebruik van de aan weerszijden van een grens bestaande medische voorzieningen'. Dit knelpunt is inmiddels ook onderkend door de Provinciale Raad voor de Volksgezondheid in Limburg. In de recente nota Volksgezondheidsverkenningen wordt uitvoerig aandacht geschonken aan de medische voorzieningen in de Limburgse grensstreken (PRVL, 1991).

Gepensioneerde pendelaars en hun gezinsleden komen echter doorgaans niet meer in aanmerking voor medische voorzieningen in het voormalige werkland. Men is aangewezen op de medische voorzieningen in het woonland. De in rekening gebrachte kosten kunnen dan veel hoger liggen, omdat men pas na pensionering is toegetreden. Het zou wenselijk zijn dat wordt onderzocht in hoeverre de gepensioneerden zich verder kunnen laten behandelen in het land waarin zij vroeger hebben gewerkt. 
Eén van de wizzen waarop niet alleen misbruik wordt gemaakt van de verschillen in de nationale stelsels van sociale zekerheidswetgeving, maar ook van de onwetendheid van (potentiele) grenspendelaars, zín de nnternationale koppelbaasprahtiken in de bouw. Deze spelen zowel n de Nederlands. Duitse als Nederlands Beigisehe grensstreek.

Nederlandse bouw wakkers worden in dienst genomen bij een aannemersbedrif in Siltard. Dif. bouwbedrif vericht alleen werkzamheden in Duitsland. De. Nedertandse werknemers verkiggen derhalve geen detacheringsverklaring van het Bureau voor Duitse Zaken, zodat de werknemers in Duitsland verzekerd moeten zin. In de door de werknemers ondertekende arbeidsovereenkomst worden de in de CAO overeengekemen regels netig verklaard ten gunste van de in het bedrif geldende regels. De werknemers ontvangen aan let eind van ledere werkdag een contant geldbedrag in Duilse marken. Verzekering in het buitenland heeft echter naar alle waarschinhijkheid dan niet plaatsgevonden (het onderzoek hiernaar is nog aan de gang).

Een Belgisch bouwbedrif heeft hoofdzakelijk Nedertanders in dienst die. via een aantal tisssenbedrijen. Worden uitgeleend en te werk worden gesteld op bouwplaatsen in Nederland Deze werknemers krigen een Betgische arbeidsovereenkomst. hetgeen illegaal is: men zou een Beigische detacheringsverklaring of een Nederlandse arbeidsovereenkomst noeten krijgen. Volgens deze arbeidsovereenkomst zijn de sociale lasten argedragen in Belgiè. De werknemers kijgen het loon contant litbetaald. Zij blijken echter, bij navraag, onverzekerd te zijh en bijvoorbeeld ook geen vakantiegeld te ontvangen. Na onderzoek van de Belgische justite blijkt het bedriff uit niet meer dan een brievenbus te bestaan.

In het vervolg van deze paragraaf zal achtereenvolgens nader worden ingegaan op enkele specifieke belemmeringen tussen Duitsland en Nederland, tussen België en Nederland en tussen België en Duitsland.

\section{Specifieke knelpunten tussen Duitsland en Nederland}

Op initiatief van de Euregio Twente-Westmünsterland is medio 1989 een brede werkgroep 'pendelaars' samengesteld, die een uitvoerige inventarisatie heeft gemaakt van de knelpunten rondom de Nederlandse en Duitse wetgeving op het gebied van belastingen en sociale zekerheid. De belangrijkste knelpunten worden hieronder besproken.

\section{Ziekte(kosten)verzekering}

De gezinsleden van een Nederlandse grensarbeider kunnen, ofschoon ze in Duitsland verzekerd zijn, in principe geen gebruik maken van Duitse voorzieningen. Wordt de echtgenote van een in Duitsland verzekerde Nederlandse grensarbeider 65 jaar, dan zal zij zich in Nederland particulier moeten verzekeren. Wanneer een Nederlandse grensarbeider 65 jaar wordt en daardoor in Duitsland wordt uitgesloten van de Krankenversicherung der Rentner, dan zal hij of zij zich in Nederland particulier moeten verzekeren. Men komt evenmin in aanmerking voor een "Zuschuss" van de Duitse Rentenversicherungsanstalt. De Nederlandse grensarbeider heeft in Nederland geen recht op voorzieningen volgens de AAW. Ontvangt een arbeidsongeschikte Nederlandse grensarbeider een Duitse Arbeitsunfähigkeitsrente die meer bedraagt dan zijn WAO-uitkering, dan hebben de gezinsleden geen recht op medeverzekering bij het Nederlandse ziekenfonds. Ontvangt de weduwe van een overleden Nederlandse grensarbeider een Duitse weduwenuitkering die meer bedraagt dan haar AWW-uitkering, dan hebben haar kinderen geen recht op medeverzekering bij het Nederlandse ziekenfonds.

\section{Arbeidsongeschiktheidsverzekering}

De Nederlandse grensarbeider die in Nederland na 52 weken ziekte arbeidsongeschikt zou worden verklaard, kan nog geen aanspraak maken op een arbeidsongeschiktheidsuitkering, omdat er volgens Duitse normen nog geen sprake is van arbeidsongeschiktheid. Wordt een Nederlandse grensarbeider na 78 weken ziekte door Duitsland arbeidsongeschikt verklaard, maar was deze ziekteperiode de laatste 52 weken niet aaneengesloten, dan kan hij of zij geen 

aanspraak maken op een WAO-uitkering, omdat er volgens Nederlandse normen nog geen sprake is van arbeidsongeschiktheid. Vanaf het moment dat Nederlandse grensarbeiders op grond van een (pro-rata) WAO-uitkering weer verzekerd zijn volgens de AAW, geldt een wachttijd van 6 jaar alvorens men aanspraak kan maken op AAW-voorzieningen.

\section{Ouderdomsvoorzieningen en pensioenen}

Wanneer Nederlandse grensarbeiders vervroegd met pensioen gaan, moet over het gedeeltelijke ouderdomspensioen dat men uit Duitsland ontvangt, premie volksverzekering worden betaald. Als gevolg daarvan loopt men het risico onder het bijstandsniveau te geraken. De echtgenote van de Nederlandse grensarbeider komt niet in aanmerking voor kinderopvoedingstijdvakken ("Kindererziehungszeiten"), ondanks de binding van haar echtgenoot met de Rentenversicherung. Wanneer de echtgenote van een Nederlandse grensarbeider gaat scheiden van haar man, krijgt zij bij het bereiken van de 65-jarige leeftijd in principe niets van het door haar man in Duitsland opgebouwde pensioen. Nederlandse vrouwen die in Duitsland een part-time dienstbetrekking hebben vervuld, zullen bij het bereiken van de 65-jarige leeftijd hun pensioen veelal moeten aanvullen met een bijstandsuitkering.

\section{Kinderbijslag}

De partner van de Nederlandse grensarbeider komt niet in aanmerking voor "Kindererziehungsgeld". De grensarbeider zal zijn dienstbetrekking moeten onderbreken of beëindigen om aanspraak te kunnen maken op deze uitkering. Nederlandse grensarbeiders zonder partner ontvangen geen Nederlandse kinderbijslag en zijn aangewezen op de lage Duitse kinderbijslag.

\section{Weduwen- en wezenuitkering}

De weduwe van een Nederlandse grensarbeider wordt bij het bereiken van de 65 -jarige leeftijd gekort op haar Duitse weduwenpensioen, indien haar AOW omgerekend (in 1989) meer bedraagt dan DM 984,-.

De heer $X$ is woonachtig in Urmond (Nederland) en werkzaam in Duitsland. Hij heeft hiervoor een detacheringsbewijs van het Bureau voor Duitse Zaken in Nijmegen verkregen en verkeert derhalve in de terechte veronderstelling ook in Duitsland verzekerd te zijn. In 1985 viel $X$ in Keulen uit een hoogspanningsmast. Hij werd met een helikopter (uit medische noodzaak) vervoerd naar een ziekenhuis in Duisburg. De rekening van de helikopter werd naar de betrokkene thuis gestuurd. De echtgenote van X ging hiermee naar het Centraal Ziekenfonds $(\mathrm{CZF})$ te Sittard. Deze weigerde de rekening te betalen omdat de verleende hutp niet tot het ziekenfondspakket behoort en stuurde de rekening terug naar de Bundesgenossenschaft. De Bundesgenossenschaft stuurde de rekening echter weer terug naar X, omdat de rekening volgens de Bundesgenossenschaft wel door CZF diende te worden voldaan. Dit gebeurde tot drie keer toe, waarbij de rekening werd verhoogd met honderden D-marken als gevolg van boete-aanmaningen. Het is ons niet bekend of en door wie de rekening uiteindelijk is betaald. De echtgenote van $x$ moest geruime tijd 300 km per dag rijden om de zeer zwaar gewonde X te kunnen bezoeken. Er werd haar niet vertefd dat zij gedurende die kritieke periode in Duisburg had kunnen logeren, omdat men niet wist wie de verblifkosten zou betalen. De reiskosten gemaakt door de echtgenote, zouden echter worden vergoed door de Bundesgenossenschaft. Toen hiervoor een vergoeding werd aangevraagd werd echter naar het CZF verwezen. Deze achtte zich echter op haar beurt eveneens niet aansprakelik, omdat de Nederlandse wetgeving alleen spreekt over verpleging in een in Nederland gelegen ziekenhuis. De heer X kwam ruim twee maanden na het ongeval naar huis om even op rust te komen en kreeg toen van het CZF bericht dat hij niet meer in Duitsland behandeld mocht worden. Dit ondanks reeds gemaakte afspraken voor verdere consulten en behandelingen en ook ondanks het feit dat de huisarts en andere artsen de voorkeur gaven aan verdere behandeling in Duisburg. De betrokkene is toen in het ziekenhuis van Sittard verder behandeld. 



\section{Specifieke knelpunten tussen België en Nederland}

Overeenkomstig de hoofdrichting van de pendel tussen België en Nederland zijn de knelpunten vooral van Belgische zijde in kaart gebracht. Het Belgische Algemeen Christelijk Vakverbond (ACV) heeft reeds 20 jaar een Dienst Grensarbeiders, welke op vijf plaatsen langs de Belgische grens kantoor houdt. Het aantal jaarlijks in behandeling genomen individuele dossiers op het terrein van met name de sociale zekerheid en de pensioenwetgeving is in de periode van 1983 tot 1990 gestegen van 256 tot 421 . Enkele problemen die zich momenteel nog voordoen worden hieronder besproken.

\section{Ziekte(kosten)verzekering}

De Belgische grensarbeider (met een inkomen tot $f 52.300,-$ (in 1991)) moet aangesloten blijven bij een Belgisch ziekenfonds, maar tevens moet de Nederlandse werkgever de werknemer aanmelden bij een Nederlands Ziekenfonds. De Belgische grensarbeider is derhalve ook verplicht de nominale premie aan het Nederlandse Ziekenfonds te betalen voor zichzelf en de eventueel mee te verzekeren gezinsleden, als deze geen inkomen in België hebben. Bovendien is de Nederlandse premie hoger dan de Belgische, terwijl de meeverzekerde gezinsleden alleen gebruik kunnen maken van Belgische voorzieningen. De Belgische grensarbeider met een inkomen boven $f 52.300$, - dient een particuliere ziektekostenverzekering af te sluiten. Deze premie is echter in België fiscaal niet aftrekbaar. Bovendien zijn AWBZ-verstrekkingen niet 'exporteerbaar'. Ook is het problematisch op welke wijze de in het andere land gemaakte medische kosten terugbetaald moeten worden.

\section{Arbeidsongeschiktheidsverzekering}

Er bestaat onduidelijkheid over de gevolgen indien men in beide landen werkzaam is geweest en geheel of gedeeltelijk arbeidsongeschikt wordt.

\section{Werkloosheidsverzekering}

Hierbij treden er problemen op bij deeltijdpendel.

\section{Ouderdomsvoorzieningen en pensioenen}

Grensarbeiders dienen binnen een jaar na tewerkstelling hun partner aan te melden bij de Sociale Verzekeringsbank te Amsterdam omwille van de medeverzekering en de eigen opbouw van het AOW-pensioen. De partner zal dan wel zelf de vrijwillige AOW-premie moeten betalen. Deze is in België niet fiscaal aftrekbaar. Daar staat tegenover dat het latere recht op het AOWpensioengedeelte ten bate van die partner in België ook niet belastbaar is. Indien de partner op 65 -jarige leeftijd een eigen pensioenuitkering toegekend krijgt, op basis van eigen opgebouwde verzekeringstijdvakken, dan is dat deel echter wel belastbaar in België.

Belgische grensarbeiders worden geconfronteerd met een herberekening van het reeds toegekende Belgische rustpensioen. Deze herziening heeft ten gevolge dat het Belgische gezinspensioen wordt herleid tot het rustpensioen van een alleenstaande (omdat de partner een eigen AOW-uitkering geniet uit Nederland) sinds de AOW-wijziging in Nederland. Dit kan tot grote financiële nadelen leiden voor gepensioneerde ex-pendelaars.

\section{Kinderbijslag}

Indien één van de ouders in België werkt en de andere naar Nederland pendelt, hebben zij naast het recht op kindergeld uit België, ook recht op een aanvulling van Nederlandse zijde (bijvoorbeeld uitwonende en/of studerende kinderen). Voor zeer veel grensarbeiders is deze regeling echter onbekend, aangezien er vrijwel geen enkele instantie is die ze daarop opmerkzaam maakt. 
Een Belgisch gezin uit Kinrooi had recht op Belgische kinderbijslag (via de vader) en een Nederlandse aanvulling. omdat de moeder in Nederland werkzaam was. 2j werden hierop gewezen tjdens een voorichtingsavond van de ACV. Herberekening leidde to een toekenning van een achterstallige Nedertandse hinderbijslag van circa t 13.000 .

\section{Specifieke knelpunten tussen België en Duitsland}

Een grote groep Belgen is in Duitsland werkzaam op basis van een seizoenscontract. Daarin staat doorgaans een bepaling dat men in Duitsland geen aanspraak kan maken op een uitkering in geval van ziekte. Omdat er echter in de tijd dat men in Duitsland werkzaam is geen premie wordt afgedragen in België, kan men ook daar niet voor een ziekte-uitkering in aanmerking komen, zodat deze groep van pendelaars wat dit betreft in feite onverzekerd is.

Indien een Belgische pendelaar met een arbeidsverleden in zowel Duitsland als België, op het moment dat deze in Duitsland werkzaam is, geheel of gedeeltelijk arbeidsongeschikt wordt, dan ligt de hoogte van de uitkering op het minimumniveau. De reden daarvoor ligt in het feit dat de uitgangspunten voor de verzekeringsstelsels in beide landen uiteenlopen. In Duitsland geldt het opbouwsysteem: hoe langer men werkt des te meer rechten men opbouwt. In België geldt echter het risicosysteem, waarbij de berekening van de uitkering plaatsvindt op basis van het laatstverdiende loon.

Ook op het terrein van de Kinderbijslag doen zich bij pendelarbeid tussen België en Duitsland soortgelijke problemen voor als bij pendelarbeid tussen België en Nederland. 


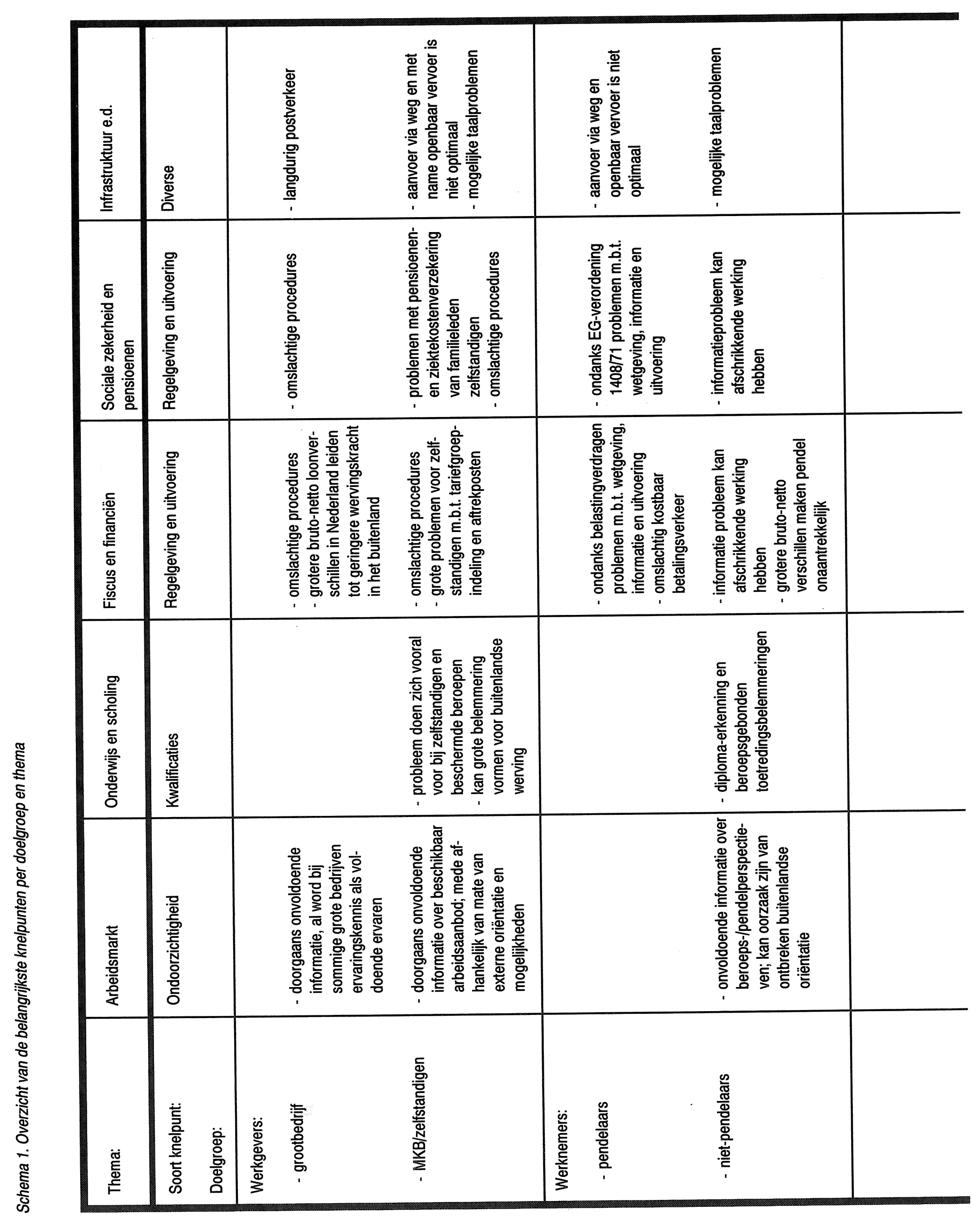




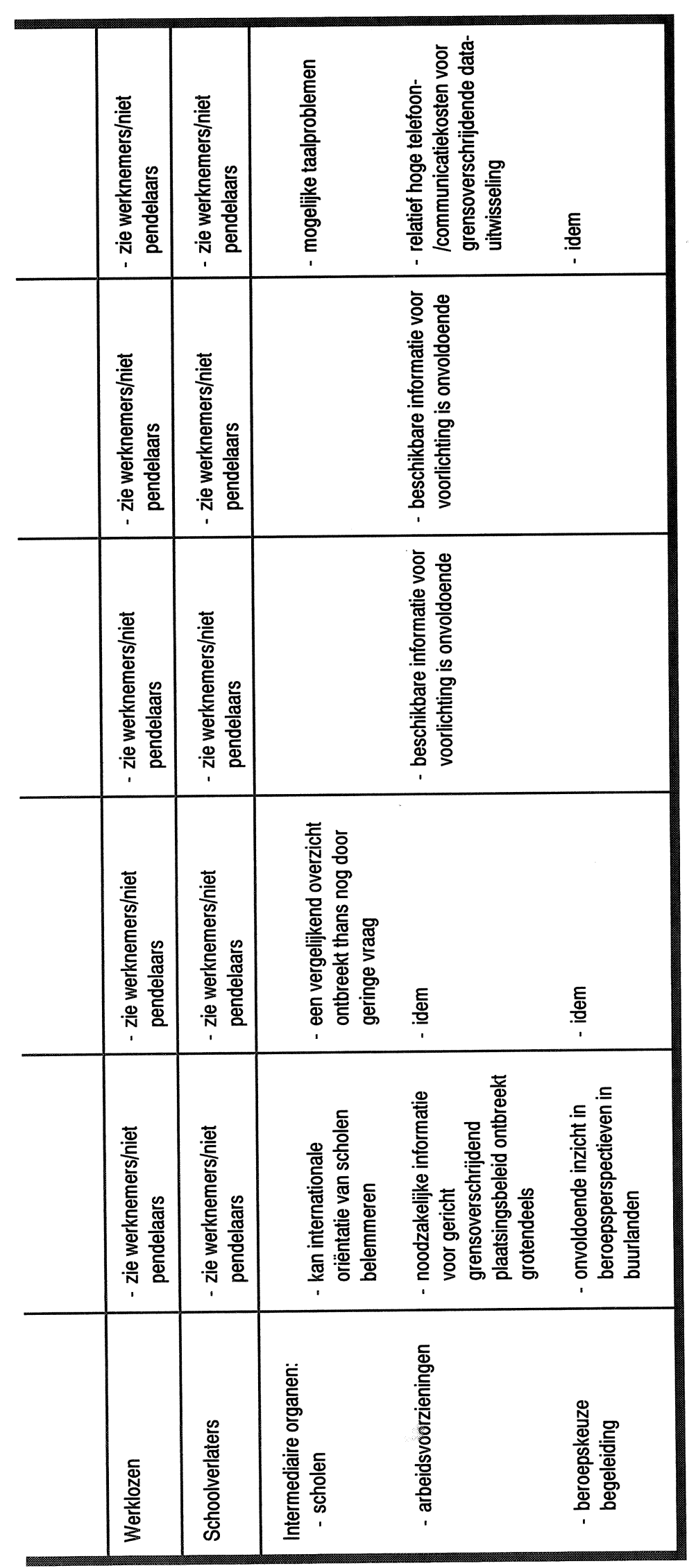




\section{HUIDIGE ACTIVITEITEN EN INITIATIEVEN}

\subsection{MLETDING}

In dit hoofdstuk wordt een overzicht gepresenteerd van een groot aantal activiteiten en beleidsinitiatieven die tot op heden zijn ondernomen, om belemmeringen rondom grensoverschrijdende arbeid en scholing weg te nemen. Daarbij wordt telkens een onderscheid gemaakt tussen een drietal beleidsniveaus: het communautair niveau, het nationaal of bilateraal niveau en het Euregionale niveau (zie paragraaf 4.2.). Het accent ligt daarbij op het in kaart brengen van de belangrijkste beleidsinitiatieven op Euregionaal niveau. Op communautair en nationaal/bilateraal niveau is de hier gegeven opsomming derhalve ongetwijfeld verre van volledig. De hier genoemde beleidsinitiatieven op deze beide laatstgenoemde niveaus hebben dan ook slechts de pretentie een indicatie te geven van de context waarbinnen de Euregionale beleidsvorming dient plaats te vinden. Ten aanzien van de initiatieven op nationaal/bilateraal niveau is bovendien met name gekeken naar Nederlandse projecten (al dan niet in samenwerking met België of Duitsland). In paragraaf 4.3. worden enkele Euregionale initiatieven op het terrein van de voorlichting en enkele Euregionale scholingsprojecten meer uitgebreid beschreven. In paragraaf 4.4. wordt tenslotte een schematisch overzicht gegeven van de belangrijkste in dit hoofdstuk genoemde activiteiten op met name het Euregionale niveau.

\subsection{OVERZICHT VAN WHTATEVEN PER THEMA}

\subsubsection{Arbeidsmarkt}

Binnen het themagebied arbeidsmarkt is er reeds sprake van een groot aantal activiteiten en beleidsinitiatieven.

Op communautair niveau:

- door het statistische bureau van de Europese Gemeenschap "Eurostat" worden vergelijkbare arbeidsmarktgegevens verzameld op basis van de in de lidstaten gehouden "Labour Force Surveys". Vooralsnog hebben deze arbeidsmarktdata betrekking op een relatief hoog aggregatieniveau naar beroep, opleiding en regio;

- teneinde grensoverschrijdende vacatureuitwisseling en arbeidsbemiddeling mogelijk te maken wordt met ondersteuning van de Europese Commissie gewerkt aan de ontwikkeling van Job Euro Transfer (JET) als opvolger van het SEDOC-systeem. JET is een speciaal op de grensgebieden gericht instrument, dat de uitwisseling van gegevens over vraag en aanbod van werk tussen de openbare arbeidsbureaus in de grensgebieden mogelijk moet maken. Tussen Tilburg en Turnhout heeft JET enige tijd proef gedraaid. Men kwam daar tot de conclusie dat het systeem niet alleen erg bewerkelijk is, maar bovendien dat er, na lang zoeken, in beide grensregio's vaak sprake blijkt te zijn van dezelfde (moeilijk vervulbare) vacatures. Hetzelfde lot lijkt andere vacature-uitwisselingssystemen beschoren te zijn, zolang niet voorzien kan worden in een essentiële tekortkoming: het ontbreken van een voldoende gedetailleerd, grensoverschrijdend, kwantitatief inzicht in de vraag- aanbod verhoudingen naar bedrijfstak en beroepsgroep. Om de samenwerking tussen de arbeidsbureaus uit de grensgebieden te bevorderen worden door de Europese Commissie seminars georganiseerd. De Commissie heeft overigens het voornemen om communautaire regelgeving te ontwikkelen voor de activiteiten van grensoverschrijdende arbeidsbemiddeling van uitzendbureaus;

met behulp van diverse EG-programma's wordt getracht de samenwerking tussen overheden, vakbonden, werkgevers en beroepsorganisaties op intraregionaal en internationaal niveau, te bevorderen; 

- onder auspiciën van de Europese Commissie verschijnen vier maal per jaar de bulletins 'Sysdem' en 'MISEP', met informatie over aspecten van respectievelijk de arbeidsmarkt en het gevoerde werkgelegenheidsbeleid in de afzonderlijke lidstaten.

Op nationaal/bilateraal niveau:

- het Nederlandse Ministerie van Economische Zaken heeft zich in de recente nota 'Regio's zonder grenzen' uitgesproken voor ondersteuning van grensoverschrijdende initiatieven;

- het Nederlandse Centraal Bestuur voor de Arbeidsvoorziening (CBA) heeft een onderzoek laten verrichten naar de omvang van de internationale arbeidsbemiddeling. In de praktijk blijkt de internationale arbeidsbemiddeling zich te beperken tot de uitwisseling van enkele bemiddelaars. Van een Europese arbeidsbemiddeling is volstrekt geen sprake (CBA, 1991).

- Enkele internationaal opererende job-management bureaus verrichten internationaal vergelijkende salarisonderzoeken en wervings- en bemiddelingsactiviteiten voor hogere managementfuncties.

\section{Op Euregionaal niveau:}

- ieder kwartaal wordt een Euregionale banenbeurs georganiseerd;

- in de Euregio Maas-Rijn wordt een elektronisch systeem ontwikkeld gericht op de informatieuitwisseling tussen de arbeidsbureaus in de Euregio met betrekking tot de geregistreerde vacatures en ter vermijding van de nadelen van JET;

- in het kader van het project Euroloket/Intensieve Grensoverschrijdende Activiteiten (IGA) worden er initiatieven genomen op het vlak van bemiddeling, beroepsopleiding en informatievoorziening langs de gehele Nederlandse grensstreek. Het Euroloketproject is een pilot-project gericht op verbetering van de vacature-uitwisseling, het opzetten van een databank Sociale Zekerheid, de vergelijking van Belgische en Nederlandse beroepsopleidingen en het verbeteren van het inzicht in de opleidingsmogelijkheden;

- op het terrein van de grensoverschrijdende arbeidsbemiddeling zijn de uitzendbureaus het meest actief;

- informatie-verschaffing aan potentiële Belgische en Nederlandse grensarbeiders door ontwikkeling en verspreiding van folders door RBA Zuid-Limburg en VDAB Tongeren.

\subsubsection{Onderwijs en scholing}

Ten aanzien van het themagebied onderwijs en scholing zijn de volgende activiteiten en beleidsinitiatieven van belang.

Op communautair niveau:

- vanuit diverse Europese programma's worden er projecten gefinancierd op het terrein van onderwijs en scholing. Naast activiteiten die plaatsvinden in het kader van de INTERREG, FORCE- en TRANSITION programma's, bestaan er op communautair niveau ook specifieke programma's ten aanzien van de:

- mobiliteitsbevordering van studenten: ERASMUS;

- samenwerking tussen universiteiten en ondernemingen met betrekking tot nieuwe technologie: COMETT;

- bevordering van vreemde-talenonderwijs: LINGUA;

- uitwisseling van jonge werknemers: 'Jeugd voor Europa';

- samenwerking en verspreiding van informatie over onderwijszaken: EURYDICE en ARION;

- voorbereiding van jongeren op werk en volwassenheid: PETRA;

- ontwikkeling van beroepsopleidingen op het gebied van nieuwe technologie: EUROTECNET;

gelijke kansen voor vrouwen, door onder meer de beroepsopleiding: IRIS;

- ontwikkeling van de beroepsopleiding door informatie, onderzoek en overleg: CEDEFOP; 
- op initiatief van EUDAT wordt eind november 1991 in Maastricht een conferentie georganiseerd met betrekking tot "The role of Information Systems for Education and Training";

- de Europese Commissie ondersteunt de ontwikkeling van een handleiding voor de beroepskeuzevoorlichtingscentra in de Lidstaten;

- voor het hoger onderwijs van drie jaar of langer is er reeds een regeling ten aanzien van de diplomaregeling tot standgekomen (zie ook hoofdstuk 3). De regelgeving voor beroepsopleidingen van minder dan drie jaar en voor getuigschriften van vakbekwaamheid is nog in voorbereiding. Deze richtlijn zal gaan gelden voor alle zogeheten "gereglementeerde beroepen". Daaronder worden zowel alle bij wet geregelde beroepen als de door CAO geregelde beroepen of overheidsdiensten bedoeld (Tweede Kamer, 1991).

\section{Op nationaal/bilateraal niveau:}

- door de Vlaamse en Nederlandse Minister van Onderwijs is in 1990 een samenwerkingsakkoord voor onderwijs (GENT) afgesloten;

- verschillende beroepsorganisaties en opleidingsstelsels uit het leerlingwezen zijn betrokken bij grensoverschrijdende scholingsprojecten.

\section{Op Euregionaal niveau:}

- in de Euregio Maas-Rijn is momenteel sprake van een beperkt aantal grensoverschrijdende scholingsprojecten. Deze zijn voornamelijk op initiatief van opleidingsinstanties en brancheorganisaties tot stand gekomen. Opvallend is dat verreweg de meeste projecten zich voor doen in de Nederlands-Duitse grensstreek. De projecten in het algemeen voortgezet onderwijs lijken zich vooralsnog meer te richten op kennismaking en uitwisseling. Bij het beroepsonderwijs lijkt er daarentegen vaker sprake te zijn van gezamenlijke scholingsprojecten, met betrekking tot onder meer de gezondheidszorg, het economisch- en administratief onderwijs, de procestechnologie en computersimulatie, metaalbewerking en het internationale transport.

- in 1987 is in de Euregio Twente-Westmünsterland de Stichting GrensOverschrijdende Beroepsopleiding (SGOB) opgericht, met als doel het ontwikkelen, opstarten, begeleiden en in stand houden van grensoverschrijdende opleidingen en cursussen. Door samenwerking en afstemming op het gebied van opleidingen, scholing en examinering dient er langzamerhand een gelijkschakeling van opleidingskwalificaties van vaklieden te ontstaan waardoor de mobiliteit van werknemers toe kan nemen.

de universiteiten in de Euregio Maas-Rijn hebben enige tijd geleden op bestuurlijk niveau een samenwerkingsakkoord gesloten. Vanaf september 1992 zal de eerste 'transnationale' studierichting kennistechnologie gevolgd kunnen worden aan de universiteiten van Hasselt/Diepenbeek en Maastricht. Problemen waarvoor binnen het GENT-akkoord nog naar oplossingen wordt gezocht hebben betrekking op de bekostiging, de studiefinanciering en de erkenning van de te verkrijgen titel (doctorandus).

\subsubsection{Fiscus en financiën}

Binnen het themagebied fiscus en financiën zijn de volgende activiteiten en beleidsinitiatieven vermeldenswaard.

\section{Op communautair niveau:}

- de Europese Commissie tracht reeds vanaf 1979 om een bevredigende richtlijn op het terrein van de direkte individuele belastingheffing te ontwerpen. Het voorstel hiervoor wordt echter nog steeds op het niveau van de Raad van Ministers geblokkeerd. De Europese Commissie laat een onderzoek verrichten naar alternatieven voor de oorspronkelijk voorgestelde richtlijn. Tegelijkertijd is de Commissie van plan om maatregelen (in de vorm van inbreukprocedures) te nemen tegen verschillende vormen van discriminatie waaraan de grensarbeiders op grond van nationale belastingregelingen zijn blootgesteld; 

- de Europese Commissie heeft een tijdelijke adviescommissie ingesteld, die een inventarisatie dient te maken van resterende problemen binnen de EG, nadat een bepaald pakket maatregelen voor het bedrijfsleven ingevoerd zal zijn. De rapportage van deze CommissieRuding zal naar verwachting eind 1991 plaatsvinden;

- de Raad van Europa heeft een zogeheten ad-hoc werkgroep 'Grensoverschrijdende Samenwerking' in het leven geroepen die zich op korte termijn (medio oktober 1991) dient te orinteren op met name de fiscale problemen bij grensoverschrijdende arbeid;

- volgens de jurisprudentie van het Hof van Justitie van de Europese Gemeenschap verbieden de regels voor gelijke behandeling niet alleen de op nationaliteit gebaseerde vormen van discriminatie, maar ook alle verborgen vormen daarvan die door de hantering van andere criteria, zoals de plaats van herkomst of de woonplaats, tot hetzelfde resultaat leiden. Dit standpunt kan een belangrijke rol spelen bij de problemen rondom de belastingwetgeving. Ten aanzien van de inkomstenbelasting worden door de VEG momenteel proefprocessen gevoerd ten aanzien van een drietal knelpunten: op het terrein van de belasting van in Nederland wonende zelfstandigen die in Duitsland werkzaam zijn; voor alleenstaande ouders die in Nederland wonen en in Duitsland werken; en ten aanzien van de aftrekbaarheid van (bijzondere) kosten voor gehandicapte kinderen van grensarbeiders.

- Door de Europese Commissie (EC, 1990) is een discussiestuk opgesteld over het verrichten van betalingen op de interne markt. Hierin wordt onder meer melding gemaakt van een inventariserend onderzoek door het Europese Bureau van Consumentenverenigingen (BEUC, 1988). Dit onderzoek heeft mede de basis gevormd voor een Aanbeveling van de Europese Commissie, over de transparantie van bankvoorwaarden voor grensoverschrijdende financiële transacties. Deze Aanbeveling bevat de uitgangspunten over het overleg met de centrale banken en de organisatie van commerciële banken.

Op nationaal/bilateraal niveau:

- Nederland, België en Duitsland hebben onderling een drietal bilaterale belastingverdragen gesloten. Deze verdragen hebben verschillende uitgangspunten: ze zijn ofwel gebaseerd op het beginsel van belastingheffing in het land waar de belastingplichtige werkt, ofwel op belastingheffing in het land waar de belastingplichtige woont;

mede op verzoek van verenigingen van grenslandbewoners is door het Duitse Ministerie van Financiën een knelpunteninventarisatie opgesteld en openbaar gemaakt. Het Nederlandse Ministerie van Financiën heeft alleen voor intern gebruik een inventarisatie verricht. Beide inventarisaties zijn tijdens bilateraal overleg tussen Duitsland en Nederland over mogelijke verdragswijzigingen aan de orde geweest. Het overleg hierover is echter in de afgelopen jaren in een impasse geraakt;

- In Nederland is de uitvoering van de belastingheffing voor in het buitenland woonachtige belastingplichtigen in Nederland, sinds begin 1991 bij één dienstonderdeel van de belastingdienst ondergebracht. Dit dienstonderdeel verstrekt ook telefonische inlichtingen over grensoverschrijdende fiscale zaken.

- De Nederlandsche Bank onderneemt geen concrete activiteiten gericht op het verbeteren van het internationale betalingsverkeer binnen de Europese Gemeenschap. Men verwacht dat de problemen opgelost zullen worden met de komst van een Europese Monetaire Unie en een Europese munteenheid. Vernieuwingen zullen moeten komen van de commerciële banken. De Vereniging van Nederlandse Banken werkt momenteel aan een raamwerk voor grensoverschrijdende samenwerking.

Op Euregionaal niveau:

- de vakbonden in de Euregio Maas-Rijn zijn hun leden behulpzaam bij het invullen van belastingaanslagen. De Belgische ACV is tevens behulpzaam bij het terugvorderen van ten onrechte ingehouden loonbelasting; 
- in het voorjaar van 1992 zal aan de Rijksuniversiteit Limburg een post-academische opleiding van start gaan over het Europees belastingrecht en de hiervoor relevante onderdelen uit het Nederlandse, Belgische en Duitse belastingrecht. In dat verband zal nagegaan worden welke expertise er bij zuster-faculteiten in de Euregio Maas-Rijn aanwezig is of ontwikkeld zou kunnen worden.

\subsubsection{Sociale zekerheid en pensioenen}

Op het terrein van de sociale zekerheid en pensioenen kunnen de volgende bestaande activiteiten en beleidsinitiatieven worden genoemd.

Op communautair niveau:

- door de Europese Commissie wordt gewerkt aan een Aanbeveling voor de lidstaten over de convergentie van de doelstellingen van sociale zekerheidsstelsels;

- een voorstel voor een Verordening 'Werkloosheid en vervroegde uittreding' welke met name de problemen rondom de VUT zou moeten opheffen wordt reeds vanaf 1980 door de Raad geblokkeerd. De Europese Commissie laat momenteel een onderzoek instellen naar de omvang van het VUT-probleem en naar mogelijke alternatieven voor de voorgestelde verordening;

- tegen lidstaten die Verordening 1408/71 niet op de voorgeschreven wijze toepassen zullen inbreukprocedures worden ingesteld;

- analoog aan hetgeen hierboven ten aanzien van de belastingen is opgemerkt, doen zich via de rechtspraak mogelijkheden voor tot coördinatie en wellicht harmonisatie van de sociale zekerheidswetgeving op basis van het 'gelijkheidsbeginsel'.

Op nationaal/bilateraal niveau:

- een Nederlands forum waar de grensgangersproblematiek aan de orde wordt gesteld is de 'Werkgroep Positie Grensgangers' van de Sociale Verzekeringsbank. Deze werkgroep bestaat uit medewerkers van de Bureaus voor Belgische en Duitse Zaken en van de Sociale Verzekeringsbank;

- vertegenwoordigers van de Bureaus voor Duitse en Belgische Zaken zijn met enige regelmaat betrokken bij overleg met Duitse en Belgische instellingen voor de sociale verzekering over onder meer aanvullende overeenkomsten bij de bilaterale verdragen inzake sociale verzekering;

- de grenscommissie van de Euregionale vakbondsraad heeft in 1983 het zogeheten 'Groenboek' opgesteld, met daarin een omvangrijke inventarisatie van allerlei knelpunten rondom grensarbeid. Dit is ter hand gesteld aan circa 500 Belgische en Nederlandse politici en bestuurders. Vervolgens is echter geen actie meer ondernomen.

Op Euregionaal niveau:

- een door de Euregio Twente-Westmünsterland ingestelde werkgroep 'pendelaars' heeft een inventarisatie opgesteld van de meest voorkomende knelpunten tussen Nederland en Duitsland op het terrein van de Sociale Zekerheid. Deze Knelpuntennota vormt de basis voor overleg met onder meer het Nederlandse Ministerie van Sociale Zaken en Werkgelegenheid;

- medewerkers van de eerder genoemde Bureaus voor Belgische en Duitse Zaken houden maandelijks spreekuur in het kantoor van de Sociale Verzekeringsbank te Maastricht;

- door vakbondsorganisaties en arbeidsvoorzieningsorganisaties in de Euregio Maas-Rijn zijn plannen gepresenteerd voor één of meerdere voorlichtingscentra, die onder meer gericht zouden moeten zijn op de gevolgen van grenspendel voor de sociale zekerheid;

- Hoewel men mag verwachten dat er bij strijdige regelingen en langs elkaar heen werkende administratieve procedures een behoefte bestaat aan grensoverschrijdende rechtsbijstand, zijn op dit punt in de Euregio Maas-Rijn alleen de juridische diensten van vakbonden actief, met concrete afspraken over grens-overschrijdende juridische bijstand voor vakbondsleden bij conflicten op het terrein van de sociale zekerheid. 



\subsection{DESCHRUVNG VAN ENKELE INTIATIEVEN EN SAMENMERKINGSPROIECTEN}

\subsubsection{Voorlichting met betrekking tot pendelproblematiek}

Verschillende instanties in de Euregio Maas-Rijn houden zich op dit moment bezig met het ontwikkelen van ideeën voor de opzet van een voorlichtingsbureau of -netwerk voor pendelarbeid. Het meest concreet zijn de voornemens van enkele arbeidsvoorzieningsorganisaties in de Nederlands-Belgische grensstreek. Volgens het projectvoorstel 'Intensieve grensoverschrijdende contacten' (IGA, 1991), is er grote behoefte aan één of meer grensbureaus waar grensoverschrijdende informatievoorziening naar werkzoekenden en werkgevers op het gebied van beschikbare vacatures, de sociale zekerheid en dagopleidingsmogelijkheden plaats kan hebben. Vanaf september 1991 zou een drietal pilot-projecten moeten gaan draaien, om de hiervoor benodigde produkten en infrastructuur te ontwikkelen. Op deze wijze wordt de voorlichting rondom de pendelproblematiek geïntegreerd met de informatieverstrekking over de arbeidsmarktperspectieven. Volgens de beoogde projectcoördinator is subsidiëring door de Europese Gemeenschap toegezegd. Inmiddels is een onderzoek gestart naar de organisatie, taakstelling en financiering van dit Euroloket-project.

Ook de interregionale vakbondsraad in de Euregio Maas-Rijn heeft medio april 1991 een resolutie aangenomen waarin wordt gepleit voor een tripartiet bestuurd bureau/secretariaat, van waaruit grensoverschrijdende projecten ontwikkeld dienen te worden. Daarnaast dient er volgens deze resolutie in iedere deelregio van de Euregio in de vakbondsgebouwen een Euregioloket te komen waar 'grens-overschrijdende servicepakketten' worden aangeboden. Daarbij gelden de met steun van de Europese Gemeenschap gerealiseerde Euregioloketten in Zuid-België en Noord-Frankrijk als voorbeeld.

Op basis van particulier initiatief heeft het Europees Informatie- en Adviesbureau thans in een drietal plaatsen in het Duitse grensgebied van Nederlands Limburg een adviesbureau geopend, terwijl voor een tweetal andere vestigingsplaatsen plannen bestaan. Tegen vergoeding van de gemaakte kosten ontvangen (potentiële) pendelaars advies en bijstand op het gebied van onder meer belastingen en sociale zekerheid. Voor grensoverschrijdende procedures wordt gebruik gemaakt van enkele bij het bureau bekende Nederlandse en Duitse advocaten.

De Vereniging van Europese Grenslandbewoners (VEG), rond 1980 door een aantal pendelende grenslandbewoners opgericht onder de toenmalige naam Lohnsteuerinitiative Vaals, is aktief op het terrein van voorlichting en belangenbehartiging van pendelarbeiders. De belangrijkste doelstellingen van de VEG zijn:

- voorlichting en advisering aan de leden;

- juridische bijstand en belangenbehartiging;

- politieke lobby en belangenbehartiging;

De VEG geeft o.a. een tweetalig 'Pendelinfo'-bulletin en een voorlichtingsbrochure ('Wonen in Nederland en werken in Duitsland') uit en heeft op vier avonden in de week een telefonisch spreekuur, waar vooral vragen over belastingen en sociale zekerheid beantwoord worden. De VEG verleent ook rechtsbijstand indien een procedure van belang kan zijn voor een grotere groep van pendelaars. Zo worden er op het gebied van belastingwetgeving en sociale zekerheid met enige regelmaat zijn enkele proefprocessen gevoerd. Daarnaast participeert men in enkele werkgroepen van Euregio's. De VEG is van mening dat veel problemen niet alleen het gevolg zijn van de wetgeving, maar ontstaan als gevolg van het feit dat de diverse betrokken instanties dikwijls langs elkaar heenwerken, zodat dezelfde gegevens dikwijls op verschillende plaatsen vastgelegd en geverifieerd worden, waardoor de uitvoering onnodig wordt vertraagd. 

De Bureaus voor Belgische en Duitse Zaken (BBZ en BDZ) houden maandelijks een dag zitting bij de Sociale Verzekeringsbank (SVB) Maastricht. Vooraankondiging daarvan vindt plaats via advertenties in de lokale media. Men kan hier terecht voor voorlichting en adviezen over diverse grensoverschrijdende zaken, die met name betrekking hebben op de sociale verzekeringswetgeving en -uitvoering voor loontrekkenden in respectievelijk België en Duitsland. Het schriftelijke voorlichtingsmateriaal dat daarvoor bij BBZ aanwezig is, beperkt zich tot een erg beknopte weergave van de relevante nationale regelingen. Een nadeel van het spreekuur is de geringe toegankelijkheid als gevolg van het beperkte aantal zittingsdagen (11 per jaar), de weinig centrale ligging van de SVB, het feit dat men alleen op afspraak en bovendien slechts onder werktijd bereikbaar is.

\subsubsection{Scholingsprojecten}

In de Euregio Maas-Rijn is momenteel sprake van een beperkt aantal grensoverschrijdende scholingsprojecten. Deze projecten zijn voornamelijk op initiatief van opleidingsinstanties en branche-organisaties tot stand gekomen. In de Euregio is in het verleden een aantal arbeidsbureaus betrokken geweest bij het Euregionaal Vakopleidings Experiment (EVE-)project. Dit project betrof beroepsopleidingsexperimenten op het gebied van CNC-draaien en -fresen, en een opleiding tot in- en uitklaringsdeclarant. Voor beide projecten zocht men naar aansluiting op de hoogste eisen die worden gesteld in de verschillende landen. Beide projecten zijn echter doodgebloed omdat de medewerking van de verschillende participanten achterbleef bij de toezeggingen en er bovendien sprake was van een uiterst geringe belangstelling van de kant van bedrijven en cursisten.

Momenteel zijn er aanzetten tot samenwerking op het gebied van Euregionale opleidingen in:

- de gezondheidszorg (Provinciale Ziekenhuisraad, Hogeschool Sittard);

- Hoger Economisch en Administratief Onderwijs (Fachhochschule Aachen en Hogeschool Heerlen);

- procestechnologie en computersimulatie (Stichting Technologiecentrum Limburg en Vervolmakings Instituut Industriële Applicaties);

- metaalbewerking (IHK Aachen en SOM Heerlen).

In Noord-Limburg werkt het Arbeidsbureau Venlo samen met de Arbeitsamter van Mönchen Gladbach, Krefeld en Wesel in het project Scholing Internationaal Chauffeur. De start van dit uit het Interregprogramma gefinancierde project zal plaatsvinden in september 1991.

In 1987 is in de Euregio Twente-Westmünsterland de Stichting GrensOverschrijdende Beroepsopleiding (SGOB) opgericht. SGOB is een stichting naar Nederlands recht met tevens Duitse rechtspersoonlijkheid, met als doel het ontwikkelen, opstarten, begeleiden en in stand houden van grensoverschrijdende opleidingen en cursussen. Het SGOB-bureau telt momenteel tien medewerkers en biedt lesprogramma's aan op het gebied van Metaal, Textiel en Milieu-techniek.

De achterliggende idee daarbij is dat door samenwerking en afstemming op het gebied van opleidingen, scholing en examinering, er langzamerhand een gelijkschakeling op opleidingen van vaklieden ontstaat, waardoor de mobiliteit van werknemers zou kunnen toenemen. Sedert april 1989 heeft de Euregio Twente-Westmünsterland een projectleider voor arbeidsmarkt en beroepsopleiding in dienst. Deze heeft, samen met SGOB cursussen tot ontwikkeling gebracht op het gebied van:

- plaatbewerking;

- modelmakerij en gieterij;

- betonstaal vlechten en buigen;

- lassen;

- kunststofindustrie; 

- bouw;

- opleidingen voor hotel en restaurant en toerisme;

- de zorgsector (ziekenhuizen, bejaardentehuizen);

- agrarisch onderwijs;

- grensexpeditie.

Voor de financiering van de opleidingen wordt gebruik gemaakt van kaderregelingen voor scholing en arbeidsinpassing, opleidings- en ontwikkelingsfondsen, subsidieregelingen van provincies en financiering op basis van het Arbeitsförderungsgesetz.

\subsection{OVERZICHT UAN ACTVITEITEN}

De in dit hoofdstuk aangehaalde bestaande activiteiten en (beleids)initiatieven worden samengevat in schema 2 . Een vergelijking van het knelpuntenoverzicht met het schema van initiatieven en samenwerkingsprojecten leidt tot de conclusie dat de meeste initiatieven op het terrein liggen van de informatievoorziening, in beperkte mate aangevuld met bijstandverlening, of betrekking hebben op kennismaking en uitwisseling. Daarnaast zijn er ook initiatieven op het terrein van de beroepsscholing. Het accent op de informatievoorziening in de bestaande initiatieven stemt overeen met de door Soeters (1991) aangegeven levensfases in de Euregionale netwerkvorming. Het is daarbij opmerkelijk dat rond de meest weerbarstige knelpunten, wetgeving en uitvoeringsprocedures met betrekking tot belastingen en sociale zekerheid, nog nauwelijks initiatieven zijn ontplooid, die daadwerkelijk tot het opheffen van deze knelpunten zouden kunnen leiden.

Een tweede conclusie die zich opdringt en waarop ook in veel gesprekken is gewezen, is de verbrokkeling van de initiatieven vanuit gescheiden circuits van vakbonden, arbeidsvoorziening en particulieren. Deze verbrokkeling brengt het gevaar met zich mee dat door de concurrentie van organisaties met vergelijkbare ideeën, de aandacht wordt afgeleid van het verkrijgen van interne overeenstemming en inhoudelijke samenhang.

Een derde cluster van conclusies is gebaseerd op de resultaten van de eerder genoemde enquête van COA-Limburg en richt zich in het bijzonder op grensoverschrijdende scholingsprojecten:

- het zijn vooral instellingen uit het hoger (beroeps-)onderwijs die participeren in grensoverschrijdende samenwerkingsprojecten;

- slechts enkele projecten (van arbeidsbureaus, leerlingwezen, HBO-instellingen) richten zich op daadwerkelijke integratie van les-, stage- en examenprogramma's;

- zeer veel Nederlandse opleidingsinstellingen zeggen op zoek te zijn naar mogelijkheden tot samenwerking. Het ontbreekt echter veelal aan concrete aangrijpingspunten voor terreinen waarop inhoudelijk zou kunnen worden samengewerkt;

- ondanks de taalverschillen is er vooral sprake van samenwerkingsprojecten tussen Nederlandse en Duitse partners. De samenwerking in de Belgisch-Nederlandse grensstreek is op het gebied van onderwijs en scholing daarentegen nog zeer gering. 



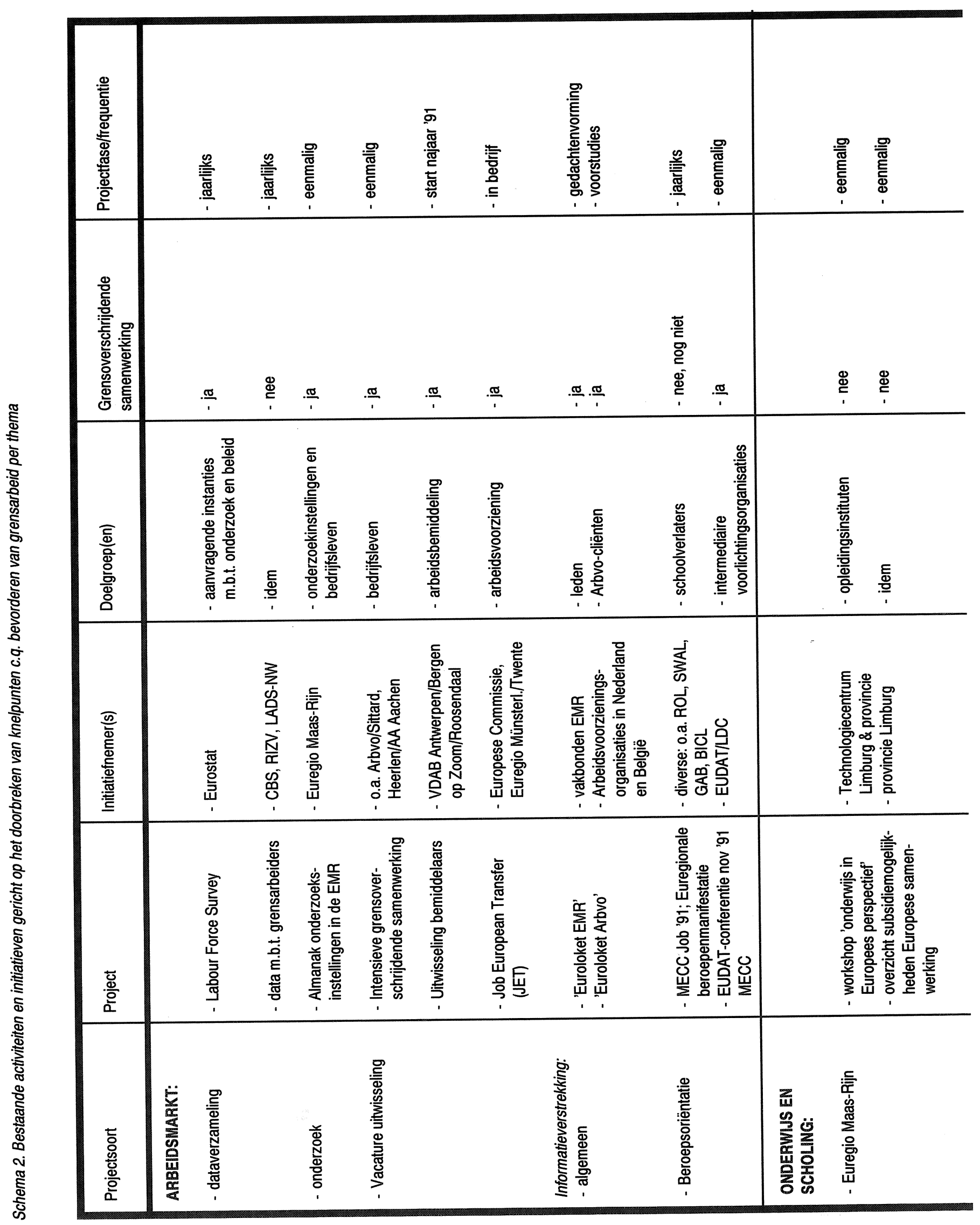





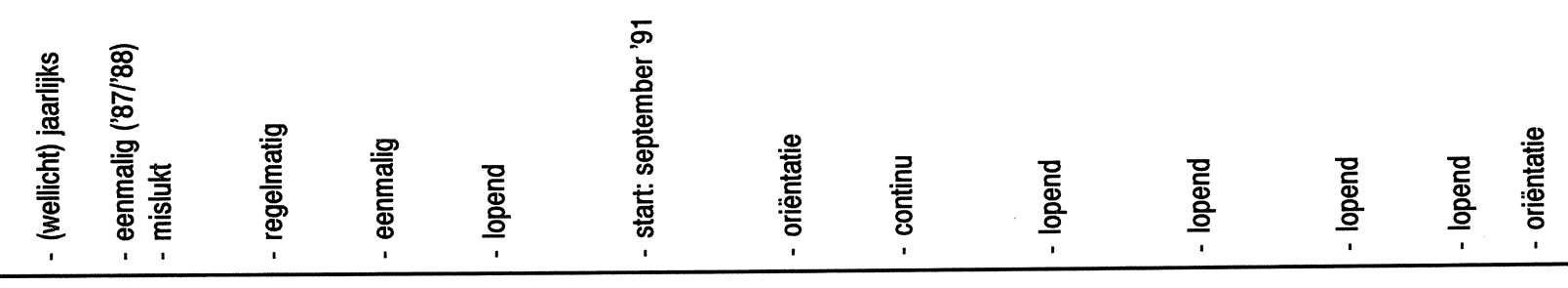

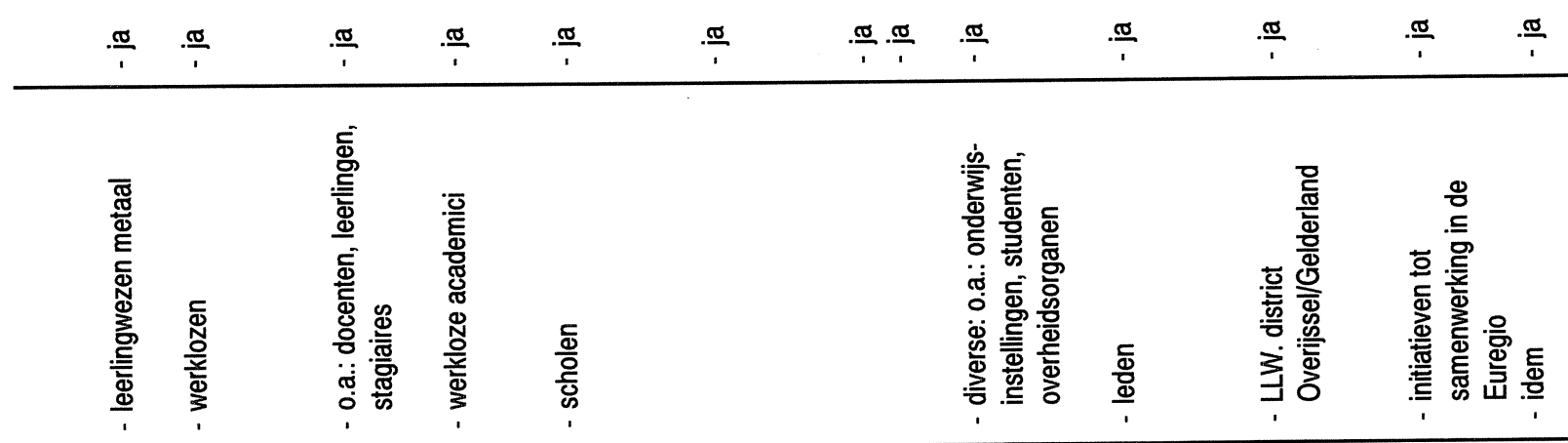

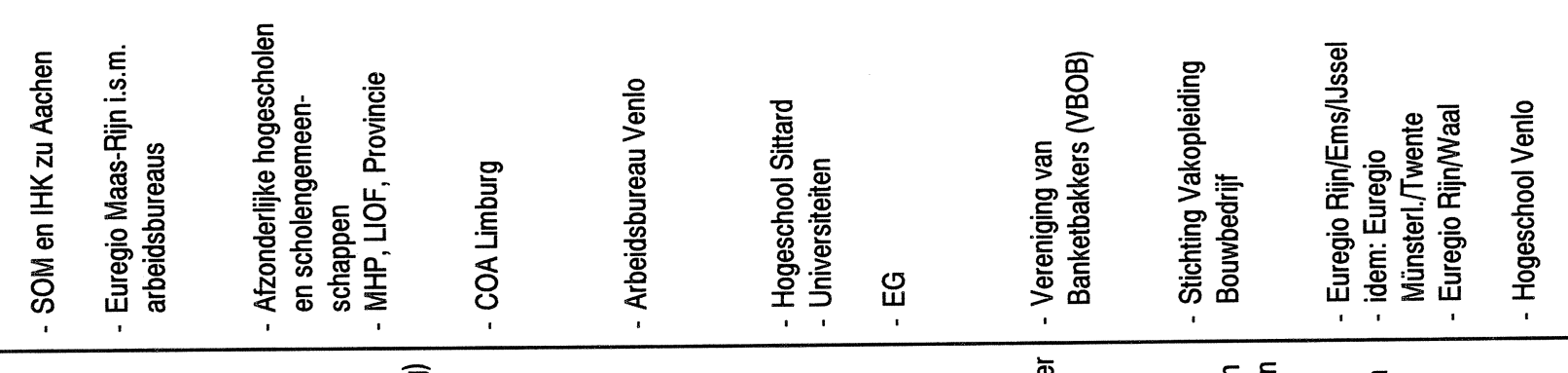

MIII




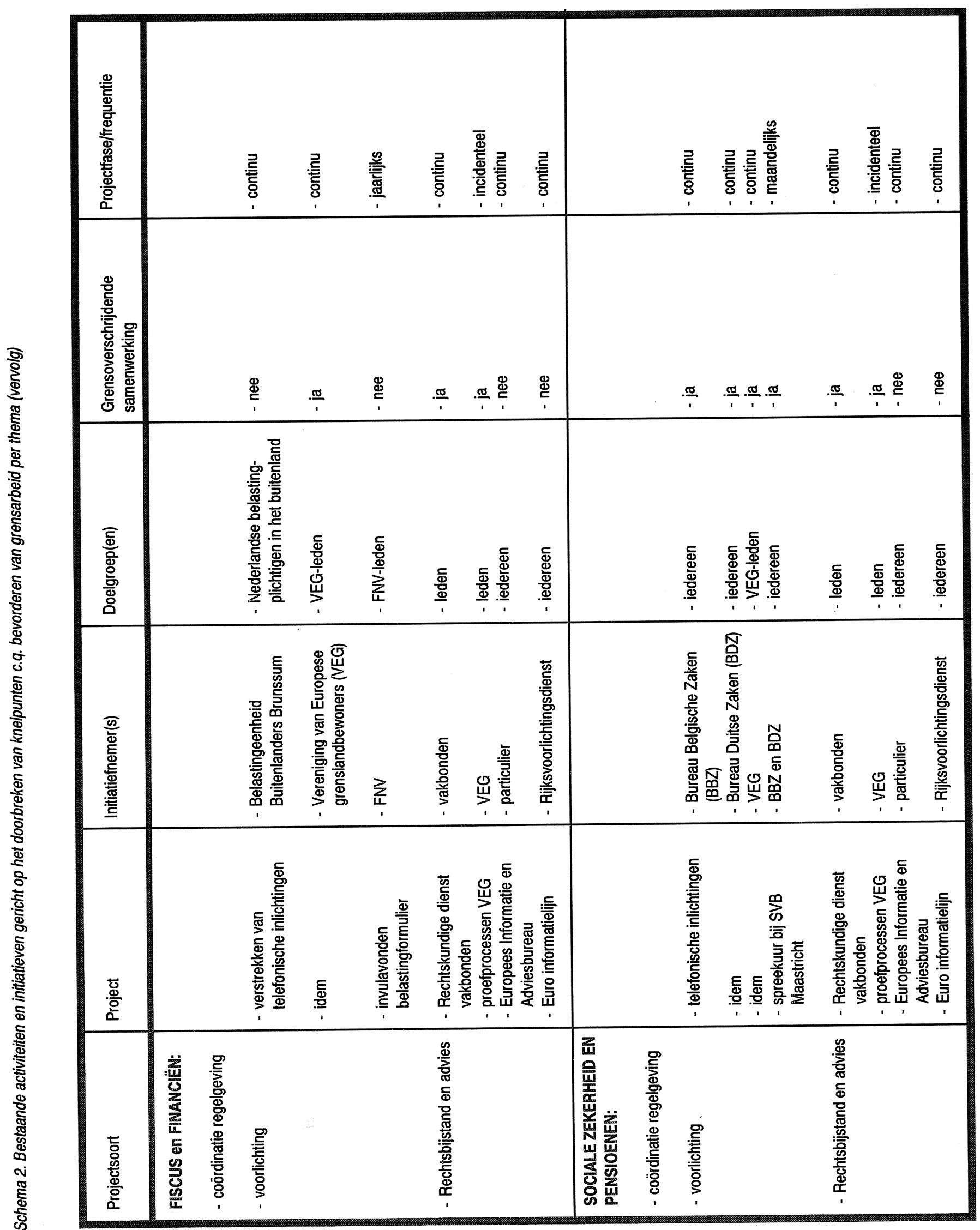





\section{AANGRIJPINGSPUNTEN VOOR BELEID}

\subsection{TNLEIDNC}

Tijdens het onderzoek is een groot aantal suggesties voor (verdere) beleidsontwikkeling naar voren gekomen in de gesprekken met pendelaars, belangenbehartigers, ambtelijke en wetenschappelijke deskundigen en leden van de begeleidingscommissie. Ook zijn enkele suggesties overgenomen uit de geraadpleegde onderzoekrapporten en beleidsnota's. In dit hoofdstuk wordt een overzicht gegeven van de diverse mogelijkheden voor beleidsontwikkeling, zoals die uit dit onderzoek naar voren zijn gekomen. Deze zijn, afgezien van enkele algemene beleidssuggesties, gerangschikt naar de vier themagebieden (zie paragraaf 5.3.). Vooralsnog is gestreefd naar een zo groot mogelijk aantal suggesties. Eerst wordt echter in paragraaf 5.2. ingegaan op een aantal aandachtspunten, waarmee bij de beleidsontwikkeling rekening zou moeten worden gehouden.

\subsection{ALOEMENE AANDACHTSPUNTEN VOOR DE BELEIOSONTWKKELING}

In deze paragraaf zal een negental meer algemene aandachtspunten worden aangestipt, die van belang zijn voor de invulling van het beleidskader van waaruit concrete beleidsvoorstellen, gericht op de totstandkoming van een Euregionale arbeidsmarkt kunnen worden geformuleerd. Het gaat daarbij om de volgende aandachts- c.q. uitgangspunten.

\section{Visie op Euregio als bestuurlijke entiteit}

Geconstateerd kan worden dat de gedachtenvorming over Euregionale samenwerking zich nog steeds in een zeer pril stadium bevindt. Er is derhalve nog nauwelijks sprake van (een aanzet tot) een politieke visie op de mogelijkheden en wenselijkheden van de Euregio Maas-Rijn als bestuurlijke eenheid. Euregionale samenwerking kan pas werkelijk gestalte krijgen nadat hierover in de participerende grensregio's enige consensus is bereikt.

\section{Motiverend beleidskader}

In het rapport van de Commissie 'Toekomst Limburg' (Buck, 1990) wordt een pleidooi gehouden voor het creëren van een wervend vestigingsmilieu voor bedrijven in de provincie Nederlands Limburg, op basis van onder meer een 'Deltaplan voor de Limburgse arbeidsmarkt'. Een soortgelijke missie zou een kader kunnen bieden voor de positionering van de verschillende beleidsinitiatieven die bijdragen aan de totstandkoming van een Euregionale arbeidsmarkt. Op deze wijze zou ook een positieve bijdrage kunnen worden geleverd aan de beeldvorming van de Euregio Maas-Rijn, zowel bij de bevolking en de bedrijven binnen de Euregio, als met betrekking tot het imago van de Euregio naar buiten toe.

\section{Bezinning op succes" en faalfactoren van samenwerking}

De grensoverschrijdende netwerkvorming loopt het gevaar te blijven steken in het genereren van op zich kansrijke ideeën, waarvan de verdere ontwikkeling stagneert. In de organisatiekundige literatuur met betrekking tot netwerkvorming en relatievorming tussen verschillende partners worden de volgende fasen beschreven (zie Soeters, 1991): 
- 'nulfase': signalering van gemeenschappelijkheid en wederzijdse afhankelijkheid.

- expressiefase: uitdrukken van wederzijds respect, vertrouwen en gemeenschappelijke interesses.

- informatiefase: uitwisseling van informatie en nieuwe ideeën en de ontwikkeling van gezamenlijke onderzoeks- en informatie-uitwisselingsprojecten.

- produktie- of joint-venture fase: produceren en distribueren van gezamenlijke goederen.

- integratiefase: geheel of gedeeltelijke herverdeling van invloed, macht, middelen en bevoegdheden.

De expressiefase vereist strategische en diplomatieke vaardigheden van de netwerkvormers. Voor de verdere ontwikkeling van ideeën zijn de juiste experts en de juiste informatie noodzakelijk. In de produktie- of joint venture fase moet er een verschuiving plaatsvinden van de 'top' van het netwerk naar de werkvloer en het gewone, alledaagse management. Netwerkvorming loopt het gevaar in de informatiefase te blijven steken. In dit hoofdstuk zal een poging worden ondernomen om beleidsinitiatieven aan te dragen op basis waarvan de stap van de informatiefase naar de produktiefase kan worden gezet.

Men kan zich echter afvragen of op dit moment de integratiefase reeds aan de orde is, aangezien geconstateerd moet worden dat er van een ontwikkelde en breed gedragen visie op een Euregionale bestuurlijke entiteit feitelijk nog geen sprake is. Voor de integratiefase is naast een overdracht van activiteiten en verantwoordelijkheden vooral ook de culturele dimensie van belang. Uit internationaal vergelijkend onderzoek (Hofstede, 1980 en Schreuder, 1990) blijkt de culturele factor van grote betekenis te zijn voor de slaagkans van internationale samenwerkingsprojecten. Meer in het algemeen kunnen de volgende voorwaarden voor het slagen van samenwerkingsprojecten worden geformuleerd (zie Grooten, 1991):

- gemotiveerde partners, zowel vanuit 'het beleid' als vanuit 'het veld';

- een goed gedefinieerd project, met meetbare doelstellingen;

- goed verdeelde rollen en een duidelijk projectmanagement;

- goede administratieve ondersteuning;

- adequate financiering.

\section{Aandacht voor potentiële pendelaars}

Het kan bij de beleidsontwikkeling van belang zijn om onderscheid te maken tussen de positie van de huidige pendelaars en de mogelijkheden die er zijn voor potentiële pendelaars. Bij deze laatste groep kan men zowel denken aan werkenden als aan werklozen, herintreders en schoolverlaters. Bovendien kan men nog een onderscheid maken tussen degenen die op zoek zijn naar een baan (loontrekkenden) en degenen die zich als zelfstandige in een buurland zouden willen vestigen.

Bij het te voeren beleid is het van groot belang dat de doelgroep van potentiële pendelaars een belangrijke plaats inneemt bij zowel de informatieverzameling, de informatieverstrekking, de arbeidsbemiddeling, de (bij)scholing, e.d. Eventueel kan men daarbij denken aan een specifiek beleidstraject ten aanzien van deze doelgroep.

\section{Aandacht voor MKB en zelfstandigen}

Het vermoeden lijkt gerechtvaardigd te zijn dat vooral het midden- en kleinbedrijf en de zelfstandigen specifieke deskundigheid missen met betrekking tot de knelpunten en de mogelijkheden van het aanstellen van werknemers uit buurlanden. Een op deze, relatief omvangrijke, groep gericht informatie- en voorlichtingstraject ontbreekt nagenoeg geheel. Daarbij zou ook nagegaan moeten worden welke knelpunten er bestaan ten aanzien van vestigingsvoorwaarden en specifieke beroepsregulerende maatregelen. Hierover dient overleg 

gevoerd te worden met branche- of beroepsorganisaties. Tevens dient een op deze doelgroep gericht voorlichtingstraject ontwikkeld te worden. Daarbij zou aangesloten kunnen worden bij de bestaande informatienetwerken van de Kamers van Koophandel.

\section{Netwerkvorming in de Euregio en tussen Euregio's}

Er bestaat binnen de Euregio Maas-Rijn nog een grote onbekendheid met de structuur van de overheidsdiensten en aanverwante organisaties in de grensgebieden. Er moet in dit verband worden opgemerkt dat de informatievoorziening over de Euregio Maas-Rijn nog gering is in vergelijking met de situatie in enkele andere Euregio's. Er dient dan ook een actiever informatiebeleid gevoerd te worden, waarmee de Euregio Maas-Rijn zich zowel binnen als buiten de Euregio kan profileren. Na gedurende een half jaar een wekelijks overzicht van publikaties uit de lokale media over provinciaal politiek-bestuurlijk nieuws te hebben gevolgd, moet helaas geconstateerd worden dat de Euregio Maas-Rijn nog nauwelijks een issue is in de lokale media. In vergelijking met bijvoorbeeld de tweemaandelijkse knipselkrant die door de Euregio TwenteWestmünsterland voor alle burgers in dat gebied wordt uitgegeven, is dat ietwat mager.

Voor de samenwerking tussen de Euregio's onderling bestaat sedert 1971 de Werkgemeenschap Van Europese Grensgebieden (WVEG) die haar secretariaat heeft bij de Euregio TwenteWestmünsterland. Ter ondersteuning van de activiteiten van deze werkgemeenschap heeft de Europese Commissie, naast het INTERREG-programma, het LACE-programma opgezet: Linkage Assistence and Cooperation for the European Border Regions. Met dit programma wordt beoogd om informatie-uitwisseling, samenwerking en externe belangenbehartiging van Euregio's tot stand te brengen.

De politici uit de Euregio dienen zich niet alleen in de Euregio als pleitbezorgers voor de belangen en problemen van grenslandbewoners te profileren, maar vooral ook in de nationale en internationale fora, waar de voor grensregio's relevante besluitvorming plaats vindt. Een netwerk van (Euro-)parlementariërs uit de grensgebieden zou wellicht mogelijkheden bieden tot beïnvloeding van de besluitvorming op Europees en nationaal niveau.

\section{Mogelijkheden voor beleidsactoren voor 'incentive-sturing'}

Per beleidsthema zou nagegaan moeten worden wat de mogelijkheden zijn voor de betrokken overheids- en uitvoeringsinstanties, om 'incentives' te creëren in de huidige subsidiestromen e.d. die op termijn zouden kunnen bijdragen aan de totstandkoming van een Euregionale arbeidsmarkt. Daarvoor zou een forum samengesteld moeten worden van gezaghebbenden op het terrein van de financiën van (Eu-)regionale overheidsinstanties. Deze zouden vóór aanvang van het nieuwe begrotingsjaar 1993 met een pakket voorstellen moeten komen. In aansluiting daarop zou een halfjaarlijks gestructureerd overleg kunnen worden opgezet tussen overheden, indien gewenst aangevuld met de sociale partners in de Euregio. Vanuit dit overleg zou kunnen worden toegewerkt naar een verdere invulling van een dergelijk beleid.

Daarnaast kan wellicht worden gedacht aan Euregionale fondsvorming vanuit de begrotingen van de deelnemende regio's, voor een directe financiering van mobiliteitbevorderende maatregelen e.d.. Door Euregionale bestuurders (Gouverneursoverleg) zouden de mogelijkheden hiertoe verkend moeten worden. Het wordt de diverse organisaties in 'het veld' (arbeidsvoorziening, onderwijs, e.d.) thans in feite onnodig moeilijk gemaakt, omdat initiatiefnemers van projecten die mede door de Europese Gemeenschap worden gefinancieerd, bij meerdere bij de Euregio betrokken overheidsinstanties, eenzelfde subsidieverzoek moeten indienen en verdedigen, al dan niet aangepast aan specifieke, regionale criteria voor subsidieverstrekking. De energie, die momenteel gestoken wordt in de 'dans om de Euregionale middelen', kan beter besteed worden aan het verkrijgen van inhoudelijke overeenstemming tussen de deelnemende partners en het verkrijgen van Europese subsidies. 


\section{Een juridisch (bestuursrechtelijk) kader voor samenwerkingsprojecten}

Sinds kort bieden het Benelux-verdrag (in werking getreden op 1 april 1991) en het 'SchlossAnholt Akkoord' (ondertekend in mei 1991, ratificatie medio 1992) een staatsrechtelijk kader voor de samenwerking tussen respectievelijk Belgische en Nederlandse overheden en Nederlandse en Duitse overheden. Deze samenwerking vond tot op heden plaats op informele of privaatrechtelijke basis. De bovengenoemde verdragen maken het mogelijk om een publiekrechtelijk lichaam te creëren, op basis van een gemeenschappelijke regeling. Een dergelijk openbaar lichaam heeft echter alleen indirekt, via de verordeningen van deelnemende overheden, de mogelijkheid om verplichtende regels voor te schrijven en of heffingen op te leggen. Het mag hierbij echter alleen gaan om een herverdeling van bestaande bevoegdheden. De voordelen van dergelijke publiekrechtelijke samenwerkingsverbanden liggen onder meer in het feit dat ze als zelfstandig rechtspersoon kunnen opereren. Bovendien kan op deze wijze structuur en bestendigheid worden gegeven aan samenwerkingsrelaties en meer mogelijkheden worden gecreëerd voor een democratische controle. De verdragen bieden echter ook mogelijkheden voor minder vergaande vormen van samenwerking op afzonderlijke beleidsterreinen (bijvoorbeeld waterhuishouding, afvalverwerking, infrastructuur en scholing).

Nagegaan zou moeten worden of er een vergelijkbaar bilateraal verdrag bestaat tussen Duitsland en België en vervolgens, of het wenselijk en politiek haalbaar is om tot een publiekrechtelijke organisatie voor de Euregio Maas-Rijn (thans een stichting naar Nederlands recht) te komen. Ook kunnen samenwerkingsorganisaties, waar wenselijk, in het leven worden geroepen voor een afzonderlijk beleidsterrein.

\section{Aanpassen wet- en regelgeving}

De bij de Euregio Maas-Rijn betrokken overheidsinstanties dienen, voor zover zij betrokken zijn bij de totstandkoming of uitvoering van wetten en regelingen, alert te zijn op impliciete of expliciete beperkingen voor grensoverschrijdende activiteiten. Dit kan bijvoorbeeld betrekking hebben op de verzekering voor ziektekosten of aansprakelijkheid voor pendelwerknemers (waarbij soms sprake is van een expliciete beperking van de werkingssfeer tot het nationale grondgebied) of tot de toelatingsvoorwaarden voor een opleiding of een scholingsproject (waarbij de toelating beperkt is tot enkele met name genoemde vooropleidingen). Hoewel op voorhand gesteld kan worden dat veel van dergelijke beperkingen ontoelaatbaar zijn ten opzichte van de juridisch hogere Europese rechtsbeginselen, zal het voor individuele burgers die hiermee worden geconfronteerd een erg lange weg zijn om hun recht te halen. Erkend moet worden dat de verantwoordelijkheid voor het vermijden van fricties ten opzichte van hogere Europese rechtsbeginselen dan ook dient te liggen bij de nationaal, regionaal of lokaal werkende overheden of instanties die betrokken zijn bij de totstandkoming of uitvoering van dergelijke beperkende bepalingen in wetten, regelingen of voorschriften.

Nog onlangs is in de Duitse deelstaat Nord-Rhein Westfalen door de SPD een wetsontwerp voorgesteld voor de zogeheten 'Pflegebeschaffung' (in Nederland: AWBZ). Hierin komen de volgende bepalingen voor: In artikel 6 wordt bepaald dat ledereen die in Duisland woont of werkt in het fonds dient bij te dragen. In artikel 4 wordt gesteld dat de verstrekkingen (bijvoorbeeld hulp bij huishouding of verpleging) alleen in het binnenland genoten mogen worden. Bovendien kunnen verstrekkingen alleen gedaan worden aan diegenen die viff laar of langer een Duitse woon. of vestigingsplaats hebben (artikel 10).

In dit verband moet ook worden opgemerkt dat er bij het opstellen van nieuwe regelgeving of het wijzigen van bestaande nationale regelgeving nog weinig gebruik lijkt te worden gemaakt van deskundigen op het gebied van de grensoverschrijdende samenwerking. 
Eén van de geinterviewde deskundigen merkte hierover het volgende op: De positie van de Stichtingen Bureau Belgische Zaken (BBZ) en Bureau Duitse Zaken in het proces van regelgeving is erg gering. terwill de Stichtingen toch zeer deskundig zijn op het gebied van de grensarbeid. De voorstellen van de Stichtingen voor wijzigingen van bepaalde regels worden op centraal niveau nogal eens stiefroederlik behandeld. Meestal wordt de Stichtingen trouwens helemaal niets gevraagd en bliken de problemen voot grensarbeiders pas op het noment dat alle regiokantoren al druk bezig zin met het doorvoeren van de nieuwe of gewijzigde regels'.

\subsection{BELEDSSUCGESTES}

\subsubsection{Algemene beleidssuggesties}

\section{Dataverzameling en onderzoek}

Op het niveau van de Euregio ontbreken, zoals reeds eerder is opgemerkt, momenteel elementaire sociaal-economische statistieken en kernindicatoren met betrekking tot het functioneren van de arbeidsmarkt. De beschikbare cijfers zijn zeer globaal en hebben betrekking op een breder gebied of zijn onderling onvoldoende vergelijkbaar door afwijkende classificaties, meetinstrumenten e.d.. Door onderzoekinstituten in de Euregio zou, in samenwerking met het statistisch bureau van de Europese Gemeenschap Eurostat, een onderzoekinstrument ontwikkeld moeten worden dat voorziet in de databehoefte in de Euregio. Daarbij zou ook een beroep gedaan kunnen worden op de medewerking van de universiteiten in de Euregio.

$\mathrm{Bij}$ de te ontwikkelen Euregio-Statistiek zou moeten worden uitgegaan van de volgende uitgangspunten:

- de statistiek moet zoveel mogelijk aansluiten bij de huidige statistieken van Eurostat en de bestaande regionale statistieken;

- de statistiek moet zoveel mogelijk tegemoet komen aan de behoeften van de diverse gebruikers: provinciale overheden, arbeidsvoorziening, bedrijfsleven, vakbonden etc..

- de dataverzameling geschiedt onder verantwoordelijkheid van de verschillende regionale onderzoeksinstellingen. De wijze waarop dit gebeurt wordt vastgesteld in een samenwerkingsverband waarin naast vertegenwoordigers van de vier deelregio's ook een vertegenwoordiger van Eurostat zit.

De Euregio-statistiek zou in ieder geval de volgende onderdelen uitgesplitst naar deelregio moeten bevatten:

1. Bevolking:

2. Economische structuur:

3. Beroepsbevolking:
- bevolkingsopbouw naar leeftijdsgroep en geslacht;

- interregionale migratie binnen de Euregio.

- aantal werknemers per bedrijfstak;

- bruto toegevoegde waarde per bedrijfstak;

- bruto-investeringen per bedrijfstak.

- aantal werknemers naar opleidingsniveau en -richting;

- instroom schoolverlaters op de arbeidsmarkt naar opleidingsniveau en -richting;

aansluiting onderwijs-arbeidsmarkt van schoolverlaters; idem, prognoses voor de komende drie tot vijf jaar. 


\section{Arbeidsmarkt:}

5. Pendelarbeid:
- aantal werklozen naar leeftijdsgroep, geslacht, opleidingsniveau en -richting;

- idem, geharmoniseerd percentage (kort- en langdurig) werklozen;

openstaande vraag naar opleidingsniveau en -richting.

aantal pendelaars naar herkomst- en bestemmingsregio.

De gegevens vermeld onder 1, 2 en voor een beperkt deel 4 zijn beschikbaar via Eurostat, zij het niet altijd op het gewenste regionale niveau. Door aanvullende gegevens te gebruiken van de nationale statistische bureaus, moet het echter mogelijk zijn om schattingen te maken voor de betreffende deelregio's. Het gebruiken van Eurostat-gegevens als vertrekpunt, heeft als belangrijk voordeel dat de wijze van dataverzameling, classificatie e.d. zoveel mogelijk uniform verloopt.

Voor de overige gegevens geldt dat een dergelijke uniformiteit in meetinstrumenten en classificatie ontbreekt. Databronnen zijn hier onder meer: de nationale statistische bureau's, de regionale arbeidsvoorziening, de ziekenfondsen en de belastingdiensten. Zo zouden de gegevens met betrekking tot de grensarbeiders die beschikbaar zijn bij de sociale zekerheidsinstanties, voor zover deze op basis van uniforme criteria worden geclassificeerd, een betrouwbaar beeld kunnen geven van de omvang en de aard van de pendelstromen en de ontwikkeling hiervan.

Om een adequaat inzicht te krijgen in de ontwikkeling van de economische structuur van de Euregio, zou het ook zeer wenselijk zijn te komen tot een stelsel van Euregionale Rekeningen in de vorm van input-output tabellen van de inter- en intrasectorale leveranties. Een dergelijke informatiebron maakt het mogelijk de effecten in beeld te brengen van beleidsvoorstellen op sociaal-economisch terrein in het algemeen en het vestigingsbeleid in het bijzonder.

Op dit moment is op een aantal onderdelen reeds summiere informatie voorhanden. Zo zijn er globale statistieken over grensarbeiders, hun herkomst- en hun bestemmingsregio's beschikbaar. Verder zijn een aantal gegevens over de economische structuur en de werkgelegenheid bekend. De gegevens over de bevolkingsopbouw en de beroepsbevolking zijn bij de nationale en/of regionale onderzoeksbureaus aanwezig. Hoewel er door EUROSTAT, het statistische bureau van de Europese gemeenschap wel pogingen worden ondernomen om tot een geïntegreerde en gedetailleerde Europese Statistiek te komen, stuit de ontwikkeling hiervan op weerstanden van nationale instellingen. De ontwikkeling van een Euregio Statistiek zou een katalyserende werking kunnen hebben op de integratie op Europees niveau.

In eerste instantie zou een inventariserend onderzoek moeten worden gehouden waarin een nauwkeurig beeld wordt geschetst van de statistische informatiebehoefte bij de verschillende doelgroepen in de Euregio. Tevens zou moeten worden onderzocht welke informatie direct of indirect beschikbaar is en wat de mogelijkheden zijn om door coördinatie van bestaande meetinstrumenten of het opzetten van nieuwe meetinstrumenten (zoals bijvoorbeeld de RUBSschoolverlatersenquête) aan de informatiebehoefte te voldoen.

De ontwikkeling van een Euregio Statistiek zal een uitstekende voedingsbron kunnen vormen voor de activiteiten met betrekking tot de onderlinge afstemming van de diplomavergelijking enerzijds (in het kader van bijvoorbeeld de verstrekking van vestigingsvergunningen voor zelfstandigen) en de ontwikkeling van onderwijsclassificaties anderzijds. Voor een dergelijke afstemming zal een vorm van coördinatie tot stand moeten worden gebracht met een mogelijke positieve kruisbestuiving tot gevolg. 



\section{Verbetering van kwaliteit en distributie van voorlichtingsmateriaal}

Ten aanzien van het beschikbare schriftelijke informatiemateriaal over fiscaliteit en sociale zekerheid kan het volgende worden geconcludeerd:

- er is relatief veel schriftelijke informatie beschikbaar over met name de belangrijkste fiscaleen sociaal-juridische gevolgen van de pendelarbeid van België naar Nederland of Duitsland en van Nederland naar Duitsland. Deze informatie is echter op weinig plaatsen verkrijgbaar. Bovendien is dit materiaal veelal opgesteld ten behoeve van intern, ambtelijk gebruik, waardoor het materiaal niet erg geschikt is voor het geven van voorlichting. Een uitzondering moet hierbij gemaakt worden voor de Vlaamse ACV en de Waalse CSC die voor de Belgische pendelaars in Nederland en Duitsland zeer handzame brochures hebben samengesteld. Hetzelfde is gedaan voor Nederlandse en Belgische pendelaars door het Benelux-bureau te Brussel. De VEG verstrekt zeer toegankelijke informatie voor Nederlandse pendelaars in Duitsland;

- er is nauwelijks schriftelijke informatie beschikbaar over de (fiscale en sociaal-juridische) gevolgen van het wonen in Duitsland en het werken in België of Nederland en er is relatief weinig informatie beschikbaar over het wonen in Nederland en het werken in België.

- de beschikbare schriftelijke informatie beperkt zich veelal tot een (gebruikersonvriendelijke) vergelijking van de fiscale en sociaal-rechtelijke regelingen. Van het 'menugewijs' aanbieden van korte 'informatieblokken' wordt nog geen gebruik gemaakt;

- er lijkt sprake te zijn van gescheiden circuits van informatieverstrekking vanuit een aantal betrokken instanties: vakbonden, arbeidsvoorziening en particuliere initiatieven. Een dergelijke verbrokkeling maakt het enerzijds onduidelijk waar men voor een bepaalde informatievraag het beste terecht kan en belemmert anderzijds een geïntegreerd voorlichtingsbeleid;

- de informatievoorziening voor werkgevers en afdelingen P\&O in hun hoedanigheid van werkgever van pendelaars en in hun hoedanigheid als mogelijk intermediair naar werknemers/pendelaars is minimaal. Ook bij grote arbeidsorganisaties ontbreekt het aan kennis over de belangrijkste instanties op dit gebied.

De gevolgen van het pendelen van België naar Nederland of Duitsland en het pendelen van Nederland naar Duitsland zijn goed in beeld gebracht. Er zijn daarentegen weinig rapporten of brochures aangetroffen, waarin de gevolgen van de omgekeerde pendel worden geïnventariseerd. Dit hangt waarschijnlijk samen met het feit dat van dergelijke pendelstromen nog nauwelijks sprake is.

Door meerdere respondenten is opgemerkt dat de informatievoorziening door de overheid over Europese-, nationaleen regionale overheidsprogramma's erg versnipperd is. De volgende opmerkingen zifn veelzeggend: 'het is toch ongelofelijk zoveel Europese programma's en subsidiemogelijkheden er alleen al zijn. Naar in de hele Euregio is er geen persoon of instantie die mij daarvan een volledig overzicht kan geven. Dan moet lk naar Brussel of Den Haag. Deze informatie zou op een centraal punt in de Euregio beschikbaar moeten zijn'. Op de geretourneerde vragenlijsten van de door het COA-Limburg georganiseerde enquête onder onderwijsinstellingen langs de Nederlandse grens kwam veelvuldig een opmerking voor in de trant van: Wii willen erg graag samenwerken met een school over de grens, maar hoe komen we aan de informatie en de middelen die daarvoor nodig zijn?

De bij de Euregio aangesloten overheden zouden een resolutie moeten aannemen en deze omzetten in daden, waarin zij zich uitspreken voor een uniform, overkoepelend en geïntegreerd voorlichtingsbeleid, ten einde een verbrokkeling van de initiatieven vanuit gescheiden circuits van vakbonden, arbeidsvoorziening en particulieren te voorkomen. In dit geïntegreerde voorlichtingsbeleid wordt niet de competentie van de uitvoerende instanties of de inhoud of reikwijdte van de wetten en regelingen als uitgangspunt genomen, maar de situatie van de burgers. 
Een voorbeeld van geintegreerde voorlichting waarbij de persoonlijke situatie van de burgers als uitgangspunt wordt genomen is het in Nedertand ontwikkelde expertsysteem voor de Sociale Diensten met betrekking tot wetgeving en jurisprudentie over de. Algemene Bijstandswet (TESSEC). Dit programma is bedoeld voor gebruik door tussenpersonen (bijstands/maatschappelijke werkers). Het Enschedese bedrif Oog \& Oor heeft een vergelijkbaar programma ontwikkeld met circa 50 wetten en regelingen voor individuele subsidies, ten behoeve van de voorlichtingscentra van gemeenten in Nederland. Burgers kunnen zelf plaatsnemen achter de terminal waar zij een aantal eenvoudige vragen over o. a. leeftijd, inkomen, huur en woonsituatie dienen te beantwoorden. Hierna wordt een lijst afgdrukt met subsidies waar de raadplegende burger wel of geen recht op heeft en waarom wel of niet. Tevens wordl aangegeven hoe en waar de subsidies aangevraagd kunnen worden.

Het geïntegreerde voorlichtingsbeleid dient onder meer te omvatten:

- voorlichting over de voornaamste specifiek voor grensarbeiders geldende aandachtspunten rondom het werken in het buitenland;

- voorlichting omtrent mogelijke knelpunten bij en de bestaande regelingen ten aanzien van pendelarbeid;

- voorlichting over de arbeidsmarktperspectieven in de buurlanden: bijvoorbeeld vacaturebanken, geautomatiseerde studie- en beroepskeuzevoorlichtingssystemen (zoals bijvoorbeeld het Nederlandse I-See!) e.d.;

- voorlichting aan bedrijven ten aanzien van de mogelijkheden in buurlanden personeel te werven, bijvoorbeeld informatie over werkzoekenden, schoolverlaters (zoals bijvoorbeeld de Nederlandse RUBS-schoolverlatersenquête) e.d.;

- voorlichting aan bedrijven ten behoeve van een integrale informatievoorziening en bijstandverlening aan pendelende werknemers en het initiëren van cursussen voor medewerkers personeelszaken met het oog op deze dienstverlening;

- voorlichting aan met name zelfstandigen ten aanzien van de vestiging in buurlanden;

- voorlichting ten aanzien van diplomavergelijking;

- voorlichting ten aanzien van concrete grensoverschrijdende samenwerkingsprojecten.

Het zou goed zijn wanneer bij de beleidsvoornemens in het kader van het 'Euroloket'-project, vorm wordt gegeven aan een dergelijke brede, geïntegreerde voorlichting vanuit een goed bereikbaar, centraal gelegen informatiecentrum.

Het Euroloket-project zou een eerste stap kunnen zijn in de ontwikkeling van een dienstencentrum met geïntegreerde lokettuncties: een zogeheten 'civic service centre'. Als gevolg van nieuwe technische mogelijkheden (bijvoorbeeld expertsystemen en publieksterminals) en veranderende behoeften en inzichten over dienstverlening door (lokale) overheidsinstanties worden door onder meer het Nederlandse Ministerie van Binnenlandse Zaken ideeën ontwikkeld voor moderne, goed geëquipeerde centra waar met behulp van automatisering en lijnverbindingen de burger (alle) overheidszaken direct kan afhandelen. Deze wordt daarbij terzijde gestaan door een hoog gekwalificeerde en generalistisch ingesteld tront office'-ambtenaar (BSO/Al, 1991). Soortgelijke projecten doen zich ook voor in landen als Duitsland ('Offenes Rathaus': Einfach und Sofort) en Belgiè en in sectoren als het bankwezen en de luchtvaart.

Door de provincie Nederlands Limburg zou een haalbaarheidsstudie geïnitieerd kunnen worden naar een Limburgs 'service centre' voor grensarbeiders. Hierin zouden loketfuncties van bijvoorbeeld Belastingdienst Buitenlanders en voorlichtende- en uitvoerende organisaties op het terrein van de Sociale Zekerheid, geïntegreerd moeten worden, bijvoorbeeld door (zo mogelijk beslissingsbevoegde) medewerkers van deze diensten te detacheren bij dit service centre. Soortgelijke studies zouden door de in Euregio Maas-Rijn deelnemende Duitse en Belgische overheden geïnitieerd kunnen worden. 


$$
\text { * }
$$


In de informatievoorziening en beeldvorming naar personen en bedrijven toe dienen niet alleen de momenteel bij grensarbeid ondervonden knelpunten benadrukt te worden, maar moeten vooral de positieve aspecten van de schaalvergroting van de (Eu)regionale arbeidsmarkt, voor zowel werkenden als arbeidsorganisaties centraal staan, zoals betere ontplooiingskansen en wervingsen afzetmogelijkheden.

\section{Rol van overheden binnen de Euregio als werkgever}

Vanuit de Europese Commissie zijn enkele programma's opgezet om kennismaking en uitwisseling van personen voor bijvoorbeeld het onderwijs, arbeidsvoorzieningsorganisaties en van groepen uitvoerende en leidinggevende ambtenaren te bevorderen. De subsidiemogelijkheden blijven in veel gevallen echter onaangesproken, omdat er weinig projectvoorstellen ingediend worden. Blijkbaar spelen ook andere barrières hier een rol. Onbekendheid met het bestaan van deze subsidiemogelijkheden is hiervoor waarschijnlijk de belangrijkste reden.

In het kader van de ministersconferentie van 19 november 1991 in Maastricht zal gesproken worden over 'het management van de ambtelijke integratie'. Daarbij zal het voornamelijk gaan over de kennismaking van rijksambtenaren met relevante instanties van de Europese Commissie in Brussel. De uitwerking van de in paragraaf 5.2 genoemde bilaterale verdragen, die een juridisch kader bieden voor publiekrechtelijke samenwerkingsprojecten, zoals onlangs tussen bijvoorbeeld Nederland en Duitsland en tussen de Benelux-landen zijn afgesloten, zal op deze conferentie echter waarschijnlijk niet aan de orde komen.

De diverse overheden of (semi-)overheidsinstellingen binnen de Euregio zouden een voortrekkersrol op de arbeidsmarkt kunnen vervullen, waarbij bovendien wederzijdse kennis en begrip van de 'beleidscultuur' in de buurlanden kan worden ingepast. Met name de uitwisseling van beleidsuitvoerend personeel, e.d., middels stages c.q. detacheringen, zou daarbij een belangrijke plaats kunnen innemen. Op deze wijze kan de bekendheid met personen en procedures in het aangrenzende buitenland worden vergroot. De afdelingen personeelszaken van de bij Euregio Maas-Rijn betrokken overheden zouden een dergelijk 'Euro-Job-rotation' actieplan moeten ontwikkelen. Terreinen waarop zich inhoudelijk gezien, interessante kennismakings- en samenwerkingsmogelijkheden voordoen, zijn onderwijs, milieu, ruimtelijke ordening, verkeer, etc. Verdergaande stappen zouden kunnen zijn het in dienst nemen van buitenlanders en de personeelswerving tevens richten op buurlanden.

Ten aanzien van het in dienst nemen van buitenlanders zijn de juridische belemmeringen als gevolg van jurisprudentie aan het Europese Hof van Justitie steeds kleiner geworden. Slechts 'bepaalde werkzaamheden', waarvoor een 'bijzondere band van solidariteit ten aanzien van de staat' gevraagd kan worden, kunnen nu nog aan de eigen onderdanen worden voorbehouden.

Er bestaat echter reeds enige jaren grote verwarring over de interpretatie en de toepassing van dit zogeheten 'functionele criterium' dat het Hof van Justitie hanteert. Het is niet alleen de rechtspraak nog niet gelukt om hierin eenduidigheid aan te brengen, maar er is ook sprake van onwil of onmacht van de meeste lidstaten om hun nationale wetgeving en praktijk aan te passen. Tot op heden heeft alleen Nederland de betreffende wetgeving aangepast (Wet 20 april 1988 tot wijziging van de Ambtenarenwet 1929, idem voor militairen). Slechts voor enkele posities, die in aparte wetten zijn geregeld (vertrouwensfuncties, benoemingen door de Kroon), geldt nog het Nederlanderschap als aanstellingseis.

In Nederlands Limburg zijn reeds vele Belgen werkzaam bij bijvoorbeeld (semi)overheidsinstellingen zoals Rijkswaterstaat, het Academisch Ziekenhuis en in het universitair onderwijs. Deze werknemers hebben allen het ambtenarenstatuut. Bij gemeenten en provincies zijn echter 
nog nauwelijks buitenlanders werkzaam. Er is bovendien, althans bij de provincie Nederlands Limburg, nog nooit 'over de grens' geworven. De reden daarvoor is dat het Nederlandse aanbod voor de meeste functies ruimschoots voldoende is, terwijl voor die specialistische functies, waarvoor het moeilijk is om goede mensen te krijgen, vaak onbekend is waarnaar gevraagd moet worden bij buitenlandse werving.

België hanteert nog steeds de nationaliteitsvereiste voor vrijwel alle overheidsposities. Recentelijk zijn echter op het Vlaamse gemeenschapsniveau twee Decreten uitgevaardigd (27 maart en 30 mei 1991), zodat alle mogelijke functies in het onderwijs (inclusief de universiteiten) kunnen worden ingenomen door ingezetenen van de Europese Gemeenschap. Daarvoor is dan wel een door het Belgisch Ministerie van Onderwijs verstrekt bekwaamheidsattest of een gelijkwaardig gesteld diploma vereist. Bovendien is in oktober 1990 in het actieprogramma GENT (Gehele Europese Nederlandse Taalgebied) van de Nederlandse en Vlaamse Ministers van Onderwijs melding gemaakt van de problemen bij dubbelbenoemingen aan Vlaamse en Nederlandse instellingen. Deze kunnen vaak niet tot stand komen als gevolg van voorschriften met betrekking tot de uitoefening van nevenwerkzaamheden.

In Duitsland wordt in het Bundesbeamtes-Rahmengesetz een onderscheid gemaakt tussen Beamten en Angestellten. Beamten worden benoemd en hebben een geheel andere rechtspositie (bezoldiging, staatspensioen) dan Angestellten. Voor een positie als Beamte is de Duitse nationaliteit vereist. Ingezetenen van andere EG-lidstaten kunnen echter wel in de positie van Angestellte benoemd worden. Het gaat hierbij veelal om banen in het onderwijs, ziekenhuizen, verpleeghuizen, universiteiten en andere publiekrechtelijke instellingen. Beamten kunnen in dienst zijn van de Bondsstaat (douane, belastingen, arbeidsbureaus), de deelstaten (politie, onderwijzers, justitie) of van de Kommunen/Kreisen (gemeente-ambtenaren, brandweer). Bij het Duitse Ministerie van Binnenlandse zaken wordt momenteel gewerkt aan een wetsvoorstel om ook de Beamtenposities voor EG-onderdanen toegankelijk te maken. Het zal echter zeker tot medio 1993 duren voordat dit tot wetswijzigingen op Landes-niveau geleid zal hebben.

Resumerend, kan gesteld worden dat er in alle drie betrokken landen van de Euregio Maas-Rijn in meerdere of mindere mate nog wettelijke beperkingen zijn aan de mogelijkheden tot toetreding bij een (semi-)overheidsinstantie 'over de grens'. De beperkingen zijn doorgaans groter voorzover het beleidsbepalende functies in de openbare dienst betreft. $\mathrm{Er}$ is wel sprake van wettelijke veranderingen in verband met de ontwikkeling van het Europese recht.

Het zou een goede zaak zijn, als overheidsinstellingen bij vacatures ook zouden adverteren in de media aan de andere zijde van de grens. Ook een informatieve brochure over het personeelsbeleid in het hoger onderwijs kan buitengewoon nuttig zijn. Daarin moet dan aandacht worden geschonken aan onderwerpen als personeelscategoriën, functie-inhoud en functie-eisen, aanstellingsprocedures, carrièreverloop, e.d.

De arbeidsvoorzieningsorganisaties zelf zouden binnen de Euregio een in meerdere opzichten belangrijke stap kunnen zetten door de uitwisseling van bemiddelingsfunctionarissen e.d., c.q. het werven van medewerkers in het aangrenzende buitenland. Op deze wijze wordt niet alleen de wederzijdse kennis van de verschillende beleidsculturen vergroot, maar wordt ook een bijdrage geleverd aan het vergroten van de kennis van het functioneren van de arbeidsmarkt in de buurregio's.

\subsubsection{Arbeidsmarkt}

Naast de in het vorige hoofdstuk genoemde activiteiten die in het kader van het Euroloket-project ontwikkeld worden (vacature-uitwisseling, informatievoorziening, scholing), zouden de volgende mogelijkheden uitgewerkt moeten worden. 

* Er ontbreekt een gedetailleerd, grensoverschrijdend, kwantitatief inzicht in de vraag-aanbodverhouding naar bedrijfstak, beroep en opleiding, een Euregio-statistiek. Hierdoor is een gerichte en zinvolle grensoverschrijdende vacature-uitwisseling niet mogelijk. Om hierin inzicht te krijgen is de ontwikkeling van een uniform coderings- en classificatiesysteem voor bedrijven, beroepen en opleidingen noodzakelijk (zie ook de eerstgenoemde algemene beleidssuggestie).

* Regionale kranten binnen de Euregio zouden moeten worden gestimuleerd om werkgevers in de buurlanden te informeren over advertentiemogelijkheden in hun blad. Het bureau van de Euregio Maas-Rijn zou deze stimulerende en initiërende rol op zich kunnen nemen.

* Het zou wenselijk zijn de gedrukte media van bemiddelingsorganen en particuliere instanties zoals bijvoorbeeld 'de Banenkrant', 'de Vacature-krant', in de gehele Euregio te verspreiden;

* Ook het bereik van andere wervingskanalen, zoals een vacaturetelefoon, 'Job-Link', e.d. zouden moeten worden vergroot.

* Hoewel er subsidies beschikbaar voor zijn, heeft er nauwelijks uitwisseling van bemiddelaars plaats. Het zou wenselijk zijn hieraan aandacht te schenken in het kader van het samenwerkingsproject van de arbeidsvoorzieningsorganisaties (IGA, 1991).

* Om de wervingsmogelijkheden onder Belgische en Duitse vrouwen te vergroten zou in Nederlands Limburg meer aandacht geschonken moeten worden aan randvoorwaardelijke faciliteiten die in Duitsland en België al zeer gebruikelijk zijn zoals bijvoorbeeld kinderopvang.

Om te komen tot een transparante Euregionale arbeidsmarkt, is de medewerking van het bedrijfsleven noodzakelijk. Het bureau van de Euregio Maas-Rijn, zou in haar rol als initiator en stimulator en in samenwerking met arbeidsvoorzieningsorganisaties en organisaties van het bedrijfsleven zoals de Kamers van Koophandel, de bovenstaande initiatieven op hun haalbaarheid moeten beoordelen.

Teneinde de doorzichtigheid van de Euregionale arbeidsmarkt te bevorderen, zou er jaarlijks een zorgvuldig voorbereid, tripartiet overleg plaats moeten vinden tussen overheden en werkgeversen werknemersorganisaties in de Euregio. Wellicht dat het RECITE-programma mogelijkheden biedt voor de financiering van een dergelijk initiatief.

\subsubsection{Onderwijs en scholing}

Zoals in hoofdstuk 4 werd aangegeven is er in de Euregio Maas-Rijn momenteel sprake van een aantal grensoverschrijdende scholingsprojecten. Deze projecten zijn voornamelijk op initiatief van opleidingsinstanties en branche-organisaties tot stand gekomen. Bovendien gaat het met name om projecten in de Nederlands-Duitse grensstreek. De projecten in het algemeen voortgezet onderwijs lijken zich vooralsnog meer te richten op kennismaking en uitwisseling. Bij het beroepsonderwijs lijkt er daarentegen vaker sprake te zijn van gezamenlijke scholing en examinering.

* Door het CBA wordt momenteel een haalbaarheidsstudie verricht naar de mogelijkheden voor de oprichting van een databank ten behoeve van de informatievoorziening, vergelijking en waardering van Nederlandse en buitenlandse diploma's. Indien een dergelijke databank, die tevens als centraal informatieloket zou kunnen fungeren, gerealiseerd kan worden, doet zich de vraag voor naar de inrichting van een eventueel decentraal netwerk. Met het oog hierop zou eventueel de Euregio Maas-Rijn kunnen dienen als proefveld.

* In de Euregio Maas-Rijn zou een simulatie-project opgezet kunnen worden waarin voor enkele beroepen (bijvoorbeeld: buschauffeur, verpleegkundige, lasser) wordt nagegaan wat op Euregionale schaal de gevolgen zouden kunnen zijn van naleving van de Eerste en Tweede richtlijn van diploma-erkenning. In dit verband is ook de ontwikkeling van zogenaamde 

'Assessment Centers' van belang, waarin de daadwerkelijke meting van kennis en vaardigheden plaats vindt. De haalbaarheid van een Euregionaal Assessment Center zou onderzocht moeten worden.

* Naast diplomavergelijking ten aanzien van beroepsopleidingen en de verspreiding van de informatie hierover, is vooral ook de integratie van onderwijsprogramma's van groot belang.

* Het is wenselijk een inventarisatie te verrichten naar de mogelijke wettelijke belemmeringen of andere regels (bijvoorbeeld subsidievoorwaarden) op nationaal, deelstaat, provinciaal, beroepsgroep of bedrijfstakniveau, die gezamenlijke scholingsprojecten in de weg zouden kunnen staan.

* Bij de in de Euregio Maas-Rijn betrokken subsidie-verstrekkers voor scholingsprojecten (overheden en scholingsfondsen) zou overeenstemming bereikt moeten worden over subsidiemogelijkheden en -voorwaarden (bijvoorbeeld ten aanzien van deelname en examinering) voor grensoverschrijdende scholingsprojecten. Voor de financiering van gezamenlijke scholingsprojecten kan ook gebruik worden gemaakt van nationale wetgeving zoals het Arbeitsförderungsgesetz of de kaderregelingen voor scholing en arbeidsinpassing, de beroeps- of bedrijfstakgebonden opleidings- en ontwikkelingsfondsen, en de subsidieregelingen van provincies en deelstaten. Voor een financiële bijdrage van de Europese Commissie zijn in principe diverse fondsen beschikbaar.

* Mogelijk is er in de Euregio Maas-Rijn behoefte aan een Stichting Grensoverschrijdende Beroepsopleiding, zoals recent ook in de Euregio Twente-Westmünsterland is opgericht. Daarbij doen zich vragen voor ten aanzien van de participanten, de wenselijke organisatiestruktuur, de financieringsbasis, het inhoudelijk programma, de relatie met bestaande opleidingstelsels e.d..

* Er dient een inventarisatie van de beroepsgerichte opleidingscentra in de Euregio Maas-Rijn te worden gemaakt. Daarbij dient onderscheid te worden gemaakt naar de verschillende opleidingsvormen en -terreinen. Hetzelfde zou gedaan moeten worden voor de verschillende branche- en beroepsorganisaties, zodat een gerichte vergelijking van opleidingsaanbod, opleidingsbehoefte en opleidingsmogelijkheden, per bedrijfstak, kan plaatsvinden. Op deze wijze wordt een beeld gekregen van overlappingen of hiaten in het opleidingsaanbod in de Euregio Maas-Rijn. De resultaten van deze inventarisatie zouden ten behoeve van de voorlichting naar een brede doelgroep kunnen worden opgenomen in een Vademecum of in een voorlichtingssyteem voor studie- en beroepskeuze als I-See!.

In de Euregio Twente-Westmünsterland is gebleken dat faalfactoren van scholingsprojecten kunnen liggen in:

- een minimale belangstelling van potentiële cursisten;

- het gebrekkig functioneren van lesprogramma's als gevolg van geringe beheersing van de vreemde taal;

- het voortijdig terugtrekken van cursisten als gevolg van het ontbreken van werkervaring en arbeidsritme, of vanwege het vinden van betaald werk.

Het is vanzelfsprekend van groot belang de kans op het optreden van dergelijke faalfactoren te minimaliseren.

In dit verband zouden bij de keuze van de te initiëren opleidingen de volgende criteria kunnen worden gehanteerd:

- de mate van 'Euregionale groei-potentie' van de betreffende sector of beroepsgroep;

- de mate waarin de opleiding inspeelt op het wegwerken van overschotten of tekorten op de arbeidsmarkt; 
- de mate waarin de opleiding werkzoekenden met een geringe plaatsingskans zou kunnen om-, her- of bijscholen;

- de mate waarin een opleiding inspeelt op Euregionalisering van de beroepskwalificatie: is er sprake van wederzijdse kennismaking, uitwisseling van stages en lesprogramma's of van identieke exameneisen en beroepskwalificaties?

* Naast de bestaande (initiatieven tot) scholingsprojecten op het terrein van de gezondheidszorg, het economisch- en administratief onderwijs, de procestechnologie en computersimulatie, de metaalbewerking en het transport, zouden de mogelijkheden onderzocht kunnen worden voor (samenwerking bij het opzetten van) opleidingen voor toerisme, grafische industrie, medische technologie, intensieve glastuinbouw, milieu-inspectie, en andere 'speerpunt sectoren' in deze Euregio.

* Een belemmerende factor voor potentiële pendelaars wordt altijd gevormd door een geringe taalvaardigheid. Een op te zetten opleidingscentrum zou korte, beroeps- of branchegerichte taal- en introductiecursussen kunnen organiseren. Nagegaan moet worden of de belangstelling voor dergelijke cursussen vergroot zou kunnen worden door kostprijsverlagende subsidies van de betrokken overheden, de Europese Commissie (LINGUA), of de nationale culturele instituten. Ook zou de Euregio Maas-Rijn, enigszins vergelijkbaar met het LINGUAprogramma op Europees niveau, een 'Euregionaal aktieplan regio-talen' kunnen ontwikkelen. Een eerste onderdeel daarvan zou een onderzoek kunnen zijn naar de talenkennis, het taalgebruik en de taalbehoefte en de opleidingsinfrastructuur en de opleidingsbehoefte in de Euregio.

Over het belang van cursussen taalvaardigheid blijkt zeer verschillend te worden gedacht. Aan de ene kant kon tijdens een groepsgesprek geconstateerd worden dat er bij buitenlandse werknemers een grote behoefte bestaat aan een korte, op maat gesneden beroepsgerichte taalmodule. Ook zin er scholingsprojecten bekend waarbij de geringe taalvaardigheid achteraf werd gezien als een belangrike faalfactor van het project. Aan de andere kant werd melding gemaakt van een minimale respons (4 reacties) op een inventariserend onderzoek onder bedrijen naar de behoefte aan aanvullende talencursussen.

* De ervaringen die internationaal zijn opgedaan met het 'trainen-van-trainers-project' kunnen voor de Euregio Maas-Rijn van groot belang zijn. Hierbij kan gedacht worden aan het opleiden van docenten voor nieuwe onderwijsvormen zoals 'open-leersituaties', afstandonderwijs, module-matig werken en een betere aansluiting met de persoonlijke achtergrond en voorkeuren van de studenten.

* Van groot belang voor de Euregio is de ontwikkeling en uitwisseling van onderwijstechnologie, dat wil zeggen het gebruik van informatietechnologie in onderwijssituaties. Hetzelfde geldt in iets mindere mate voor de uitwisseling van simulaties voor vaardigheidstrainingen.

\subsubsection{Fiscus en financiën; sociale zekerheid en pensioenen}

Het is van belang te constateren dat rond de meest weerbarstige knelpunten, wetgeving en uitvoeringsprocedures met betrekking tot belastingen en sociale zekerheid, noch op eEuropees noch op nationaal niveau tot nu toe veel initiatieven zijn ontplooid, die tot het opheffen van bestaande knelpunten zouden kunnen leiden. 


\section{Fiscus en sociale zekerheid}

* Met betrekking tot de uitvoering van de, in hoofdstuk 4 genoemde, bilaterale belastingverdragen tussen Nederland, België en Duitsland zou voor de pendelaars een aanzienlijke verbetering bewerkstelligd kunnen worden, als de werkgever en uitkerende instanties verantwoordelijk worden gesteld voor het aanvragen van ontheffing tot invordering van de direkte inkomstenbelasting (de 'grensarbeidersverklaring').

* Het recentelijk door het Hof van Justitie van de EG in de jurisprudentie uitgewerkte beginsel van gelijke behandeling van EG-ingezetenen op het terrein van de inkomstenbelastingen, zou een belangrijke rol kunnen spelen bij het zoeken naar oplossingen voor problemen waarmee de grensarbeiders op het gebied van de belastingwetgeving te kampen hebben. Het wachten is dan ook op uitspraken in proefprocessen die hierop voortbouwen.

* Per 1 januari 1991, heeft de Nederlandse belastingdienst de uitvoering van alle belastingzaken voor 'buitenlanders' in één organisatie-eenheid ondergebracht. Deze is daardoor ook aanzienlijk beter toegankelijk voor pendelaars en hun belangenorganisaties. Nagegaan zou moeten worden of een vergelijkbare concentratie en vereenvoudiging bij de Belgische en Duitse belastingdiensten bereikt zou kunnen worden.

* De Nederlandse belastingdienst schenkt tot op heden geen aandacht aan de voorlichting rondom pendelarbeid. Informatie hierover zou in ieder geval via de belastingtelefoon en de brochure-reeks van de douanedienst verstrekt moeten worden.

* De Nederlandse belastingdienst, Diensteenheid Buitenlanders, is op geen enkele wijze op de hoogte van organisatie of werkwijze van collega-belastingdiensten in Belgie of Duitsland. Voorlichting of samenwerking kunnen hierdoor niet tot ontwikkeling komen. Het is derhalve wenselijk dat de mogelijkheden tot samenwerking e.d. tussen de belastingdiensten onderzocht worden.

* De grensoverschrijdende uitvoeringsprocedures van belastingdiensten en instanties voor sociale voorzieningen zouden op 'pendelvriendelijkheid' doorgelicht moeten worden door bilaterale projectteams, ondersteund door bijvoorbeeld externe organisatiedeskundigen. Ook zouden de Bureaus voor Belgische en Duitse Zaken daarvoor personele middelen toegewezen moeten krijgen.

De sociale verzekeringspositie van grensarbeiders wordt, zoals reeds eerder is aangegeven, voor een belangrijk deel geregeld in EEG-Verordening nr. 1408/71. Volgens deze Verordening zijn grensarbeiders voor wat betreft de verplichting van verzekering en premiebetaling onderworpen aan de wettelijke voorschriften van het land waar men werkt.

* Op nationaal niveau kunnen convergentie en coördinatie tot stand gebracht worden door bilaterale verdragen en wijzigingen (aanpassingen, aanvullingen) in de nationale wetgeving. De snelste weg om tot coördinatie te komen ligt echter bij het ontwikkelen van jurisprudentie van tot op Europees niveau uitgevochten procedures. De hieruit voortkomende uitspraken gelden immers voor alle EG-landen (gemeenschapsrecht) en staan boven de nationale wetgeving. De weg om tot een Europese uitspraak te komen is echter wel langdurig en moeizaam.

* Voormalige grensarbeiders kunnen, zoals gezegd, moeilijkheden ondervinden wanneer zij een uitkering wegens vervroegde uittreding of pensionering ontvangen, omdat deze uitkeringen niet onder de werking van de bovengenoemde EG-Verordening vallen. Het voorstel tot regulering van alle brugpensioenen dat de Commissie reeds in 1980 bij de Raad heeft 

ingediend is echter nog steeds niet aangenomen, omdat hiervoor de benodigde unanimiteit tot op heden heeft ontbroken. Vooruitlopend op een Europese regeling zouden Nederland en België een bilateraal verdrag met Duitsland kunnen afsluiten, overeenkomstig het door de Europese Commissie ontworpen voorstel.

* Gepensioneerde pendelaars en hun gezinsleden komen doorgaans niet meer in aanmerking voor medische voorzieningen in het voormalige werkland. Het zou wenselijk zijn dat wordt onderzocht in hoeverre gezinsleden van (gepensioneerde) pendelaars zonder voorafgaande toestemming van de ziektekostenverzekeraar, gebruik kunnen maken van de medische voorzieningen in het (voormalige) werkland.

* De opgebouwde rechten op aanvullend pensioen behoeven volgens wettelijk voorschrift in Duitsland bij ontslag in het algemeen alleen te worden meegegeven, indien de betrokkene tenminste 35 jaar oud is en 10 jaar aan de pensioenregeling heeft deelgenomen. In België is dat - zonder leeftijdsgrens - 5 jaar. De arbeidsmobiliteit vanuit deze landen zou bevorderd kunnen worden indien ook bij eerder vertrek (bijvoorbeeld bij elk ontslag na 1 jaar, zoals in Nederland) het opgebouwde pensioenrecht in stand zou worden gelaten.

* Teneinde de arbeidsmarktmobiliteit vanuit Duitsland naar Nederland en België en vanuit Nederland naar België te vergroten, dient ook informatie verzameld te worden over de knelpunten die bij deze (potentiële) pendelstromen kunnen optreden. Er zou, in samenwerking met de (regionale) vakorganisaties en analoog aan de door de Euregio TwenteWestmünsterland ingestelde Commissie 'Knelpunten grensarbeiders', een vergelijkbare werkgroep kunnen worden samengesteld, teneinde de problemen van deze pendelaars te inventariseren.

* Nagegaan zou moeten worden of de rol die de Bureaus voor Belgische- en Duitse Zaken thans al spelen bij de uitvoering van een aantal bestaande wetten en regelingen uitgebreid zou kunnen worden tot het gehele gebied van belastingen en sociale zekerheid. Deze zouden echter niet alleen als nationale service-bureaus voor pendelaars kunnen gaan werken doch zouden ook meer betrokken moeten worden bij (de voorbereiding van) wijzigingen in wetten en bepalingen.

* Nagegaan moet worden of op het terrein van de grensoverschrijdende rechtsbijstand maatregelen ondernomen zouden kunnen worden. Gedacht kan worden aan het ondersteunen van individuele pendelaars bij de rechtsgang, het stimuleren van proefprocessen, het toegankelijk maken c.q. ontsluiten van regelgeving en jurisprudentie, etcetera. Hierbij moet worden bedacht dat de ontwikkeling van het gemeenschapsrecht vooral plaats zal hebben door het voeren van (proef)processen tot op het hoogste juridische niveau. Gezien de rol van particuliere organisaties als de VEG (on-line databank, kwartaalblad, spreekuur, proefprocessen, e.d.) en vakorganisaties (onder andere de Dienst Grensarbeiders van de Belgische vakbond ACV) met spreekuren en juridische dienst, zouden deze daarin meer financiële, materiële of in ieder geval morele ondersteuning kunnen gebruiken. Daarnaast zou ook gedacht kunnen worden aan het toevoegen van een dienst Rechtbijstand aan bijvoorbeeld het Euroloket. Bij de Bureaus voor Rechtshulp en commerciële advocatenkantoren is de expertise voor grensoverschrijdende juridische conflicten op het terrein van rechtsgang, fiscaliteit en sociale zekerheid, overigens nagenoeg niet aanwezig.

\section{Financiën}

* Voor wat betreft de financiële problemen als gevolg van mogelijke schommelingen in wisselkoersen en de hoge banktarieven voor grensoverschrijdend betalingsverkeer, verwacht de Europese Commissie dat de totstandkoming van het Europees Monetair Systeem en de 
verwezenlijking van de Economische en Monetaire Unie zullen leiden tot een oplossing van deze problemen. Met name de vakorganisaties laten echter nog regelmatig een pleidooi horen voor het invoeren van een egalisatiefonds, van waaruit een speciale vergoeding door de overheid aan grensarbeiders kan worden verstrekt, ter compensatie van de nadelige gevolgen van wisselkoerswijzigingen. Recentelijk is een dergelijk egalisatiefonds tussen Frankrijk en België evenwel afgeschaft. Het afnemende belang van een dergelijk fonds als gevolg van de toegenomen stabiliteit van de wisselkoersverhoudingen is hiervoor een belangrijk motief geweest.

* Volgens een discussiestuk van de Europese Commissie (oktober 1990) zullen de verbeteringen van de in hoofdstuk 3 (3.3.) genoemde knelpunten vooral tot stand moeten komen door een sterkere financiële mededinging in de financiële sector te bewerkstelligen. Daarnaast is een systeemtechnische samenwerking tussen de commerciële- en centrale banken en andere financiële instellingen vereist. Naar de mening van een benaderde deskundige van de Nederlandsche Bank zal een goed en goedkoop grensoverschrijdend betalingsverkeer pas mogelijk zijn indien er een monetaire unie tot stand is gekomen.

Voor de ontwikkeling van het grensoverschrijdend betalingsverkeer kunnen als criteria gesteld worden dat de transacties snel en tegen redelijke kosten verricht moeten worden. Er moet sprake zijn van een gegarandeerde veiligheid en rechtszekerheid en van een betrouwbare controle daarop.

\subsection{NAAR EEN EUREGONALE ARBEIDSMARKT}

De vele eerder genoemde beleidssuggesties illustreren dat de ontwikkeling van een Euregionale arbeidsmarkt een proces is, waarbij een groot aantal aspecten van belang is. Bovendien spelen talrijke actoren op (Eu)regionaal, nationaal en communautair niveau een rol van betekenis.

Vanuit dit oogpunt is het goed om een onderscheid te maken tussen de beleidsinitiatieven die op korte termijn zouden kunnen worden ontplooid en de beleidsinitiatieven die op (middel)lange termijn ontwikkeld zouden kunnen worden.

Op de korte termijn zullen er ongetwijfeld, zowel binnen de Euregio Maas-Rijn, als daarbuiten op de diverse beleidsterreinen talloze initiatieven worden ontplooid door overheden, arbeidsvoorzieningsorganisaties, vakverenigingen, onderwijsinstellingen, belangenverenigingen van pendelaars e.d. Hoewel het aan de ene kant aantrekkelijk is dat een grote verscheidenheid aan organisaties een bijdrage levert aan de totstandkoming van een Euregionale arbeidsmarkt, kan dit tegelijkertijd ook nadelig zijn indien allerlei initiatieven elkaar overlappen of zonder enige coördinatie worden ontwikkeld.

Voor een meer gecoördineerde aanpak waarvan het geheel meer is dan de som der delen, zal in eerste instantie binnen de Euregio Maas-Rijn een vijftal beleidsinitiatieven nuttig kunnen zijn:

- het formuleren van een politieke visie op de mogelijkheden en wenselijkheden ten aanzien van de bestuurlijke samenwerking in de Euregio Maas-Rijn;

- het formuleren van een motiverend en inspirerend beleidskader, waarbinnen de verschillende meer concrete beleidsinitiatieven kunnen worden gepositioneerd;

- een aanzet geven tot de netwerkvorming binnen de Euregio, door het instellen van een 'Euregio Adviesraad' en thematische werkgroepen bestaande uit overheidsvertegenwoordigers, sociale partners en andere belanghebbenden (zie ook Buck, 1990);

- het voteren van regionale gelden ten behoeve van de beleidsterreinen die prioriteit hebben in het kader van de Euregionale samenwerking, in centrale Euregionale fondsen;

- het ontwikkelen van een actief informatiebeleid, waarmee de Euregio Maas-Rijn zich zowel binnen als buiten de Euregio kan profileren. 
Vanuit de Initiatiefgroep Euregioncongres zou een appèl gedaan kunnen worden in de richting van het Gouverneursoverleg om op bovengenoemde punten beleidsinitiatieven te ontplooien.

Vanzelfsprekend zou er op relatief korte termijn reeds een aanzet gegeven kunnen worden tot verschillende van de in de vorige paragrafen van dit hoofdstuk genoemde zeer concrete beleidsinitiatieven op het terrein van voorlichting en uitwisseling. Daarbij kan bijvoorbeeld worden gedacht aan:

- het ontwikkelen van een Euregio Statistiek. Deze statistiek kan ook een uiterst nuttige functie vervullen in de gewenste netwerkvorming;

- het verbeteren van de kwaliteit en de distributie van voorlichtingsmateriaal over de Euregio Maas-Rijn in het algemeen;

- het opzetten van een Euroloket voor de voorlichting over de sociale zekerheid en fiscaliteit in de Euregio Maas-Rijn;

- het uitwisselen van beleidsuitvoerend personeel e.d. tussen overheidsinstellingen en arbeidsvoorzieningsorganisaties door middel van stages of detacheringen.

De ontwikkeling in de richting van een Euregionale arbeidsmarkt zal, zoals hierboven reeds werd aangegeven, niet alleen afhankelijk zijn van de stappen die op dit terrein binnen de Euregio Maas-Rijn worden gezet. Ook allerlei ontwikkelingen in de richting van een Gemeenschappelijke Europese markt zijn vanzelfsprekend van groot belang. Daarnaast zullen vooral op het terrein van belastingen en de sociale zekerheid ook de bilaterale regelingen tussen lidstaten eveneens een belangrijke rol spelen, indien bepaalde ontwikkelingen op communautair niveau stagneren.

Hoewel de ontwikkelingen op communautair en nationaal niveau vanzelfsprekend van groot belang kunnen zijn voor de totstandkoming van een gemeenschappelijke arbeidsmarkt in de Euregio Maas-Rijn, moet ook worden beseft dat juist de samenwerking in de grensregio's een belangrijke stimulans kan geven aan de Europese samenwerking in het algemeen. De Euregio's vervullen daarmee een belangrijke katalysatorfunctie voor het Europese integratieproces. 


\section{LITERATUUR}

\section{PUBLIKATIES VAN SELANG VOOR NEDERLANDSE PENOEL:}

\section{Algemeen:}

CBA (1991), Internationale arbeidsbemiddeling. Onderzoek uitgevoerd door het Nederlands Economisch Instituut (NEI), in opdracht van het Centraal Bureau voor de Arbeidsvoorziening (CBA), Rijswijk.

ETIL (1990), Vraag en aanbod op de arbeidsmarkt in internationaal perspectief, ETIL onderzoekrapport, Maastricht.

ETIL (1991), Beroepskwalificaties in internationaal perspectief, ETIL-onderzoekrapport, Maastricht.

FNV (1991), FNV-Europees Programma, Amsterdam.

KPMG (1991), Klynveld Management Consultants. Trends en ontwikkelingen in Human Resource Management in Limburg, Eindhoven.

Nederlandse Belastingdienst/Directie Douane, diverse voorlichtingbrochures, Rotterdam.

SVR, Werken in het Buitenland, Voorlichtingsbrochure Sociale Verzekeringsraad, Amsterdam.

VSV (1991), De kleine gids voor de Nederlandse sociale zekerheid, Kluwer/VSV, Deventer/ Amsterdam.

\section{Naar België:}

BBZ (1991), Vergelijkend Overzicht van de Nederlandse en de Belgische sociale verzekerings wetgevingen voor loontrekkenden, per 1 januari 1991, Stichting Bureau voor Belgische Zaken.

BBZ (1991), De Sociale Verzekering van (buitenlandse) werknemers in België, Voorlichtingsstencils, Stichting Bureau voor Belgische Zaken.

Benelux (1991), Voorlichtingsrapport voor Nederlandse grensarbeiders in België, secretariaatgeneraal Benelux, Brussel.

\section{Naar Duitsland:}

BDZ (1989), Jaarverslag 1989, Bureau voor Duitse Zaken, Nijmegen.

BDZ (1991), Pensioenen en renten. Overzicht van de aanspraken op Nederlandse en Duitse pensioenen (uitkeringen) en renten uit de wettelijke sociale verzekeringen, met toepassing van de daarvoor geldende EEG-bepalingen. Bureau voor Duitse Zaken, Nijmegen. 
. 
BDZ (1991), De sociale verzekering van in Nederland wonende werknemers die in de Bondsrepubliek Duitsland werkzaam zijn, Bureau voor Duitse Zaken, Nijmegen.

Euregio (1989), Knelpuntennota Grensarbeiders, Euregio Twente-Westfalen, Enschede/Gronau.

Euregio (1989), De Duitse en Nederlandse Sociale Verzekeringen. Een vergelijkend overzicht. Samengesteld door L. Opheikens en H. Neumeister, Enschede/Gronau.

Ministerie van Sociale Zaken en Werkgelegenheid (1991), Grensarbeiders en sociale zekerheid in de betrekkingen tussen Nederland en de Bondsrepubliek Duitsland. Een reaktie op de Knelpuntennota Grensarbeiders van het Samenwerkingsverband te Enschede/Gronau. Ministerie van Sociale Zaken en Werkgelegenheid, Hoofdafdeling Verdragen, Den Haag.

VEG, Pendel-Info, Kwartaalblad Vereniging Europese Grenslandbewoners, Landgraaf.

VEG (1990), Einige Anmerkungen aus der Sicht der Deutsch/Niederländischen Grenzgängern.

VEG (1991), Wonen in Nederland en werken in Duitsland. Richtlijnen voor grensarbeiders. Informatieboekje Vereniging van Europese Grenslandbewoners, Kerkrade.

\section{BUELIKATIES VAN BELANG VOOR BELCHCHE PENDEL:}

\section{Algemeen:}

Goethals (1990), Grensarbeid in de Euregio Maas-Rijnland en Saar-Lor-Lux, onderzoekverslag, Hoger Instituut voor de Arbeid, Leuven.

\section{Naar Duitsland:}

ACV (1991), Informatiebrochure voor (Belgische) grensarbeiders in Duitsland, Algemeen Christelijk Vakverbond, Dienst Grensarbeiders, Eupen.

\section{Naar Nederland:}

ACV (1989), Diverse brochures en pamfletten voor Belgische grensarbeiders werkzaam in Nederland. Algemeen Christelijk Vakverbond, Dienst Grensarbeiders, Hasselt. In het bijzonder: Verslag debatavond 10.4.1987, Hengelhoef.

VDAB (1990), Verleg uw grenzen. Arbeidsbemiddeling aan de grenzen tussen beide Limburgen. Verslag van seminarie te Tongeren, 29 en 30 November 1990, Vlaamse Dienst voor de Arbeidsbemiddeling.

BENELUX (1991), Voorlichtingsrapport voor Belgische grensarbeiders in Nederland, secretariaatgeneraal Benelux. 


\section{PUBLKATIES VAN BELANC VOOR DUTSE PENDEL:}

geen publikaties aangetroffen

\section{PUBLIKATES OVER SAMENWERKING EN ONTWIKKELING IN DE EUREGIO MAASHRN EN ANOERE EUREGIO'S}

\section{Algemeen}

WVEG (1991), Informatiebrochure over Linkage Assistance and Cooperation for the European border regions (LACE), Werkgemeenschap van Europese Grensgebieden, Gronau.

\section{Economische ontwikkeling Euregio Maas-Rijn}

Buck (1990), Waar liggen de grenzen? Limburg 25 jaar verder. Rapport van de Commssie 'Toekomst Limburg'. Rapportage door Buck Consultants International, Nijmegen.

Hans-Böckler-Stiftung (1986), Ontwikkeling van de economische struktuur in de Euregio MaasRijn, Samenvatting van een onderzoek in opdracht van de Interregionale Vakbondsraad in de Euregio Maas-Rijn, Aken.

ILS (1982), Institut für Landes- und Stadtentwicklungsforschung des Landes Nordrhein-Westfalen, Strukturanalyse für die Euregio Maas-Rhein. Grundlagen für das Grenzüberschreitende Aktionsprogramm' für die Euregio Maas-Rhein, Dortmund.

Maks, J., e.a. (1987), De economische gevolgen van het Europese integratiebeleid voor de provincie Limburg: een eerste empirische studie, Maastricht.

Zinn, K.G. (1985), Entwicklung der Wirtschaftsstruktur der Euregio Maas-Rhein. Analyse von Beschäftigung und Produktion anhand von Regional-, Struktur- und Standortfaktoren, Aachen.

\section{Opleidings- en scholingsprojecten in EMR en andere Euregio's}

Arbeidsbureau Nijmegen (1991), Scholingsproject tot internationaal management and marketing assistent, Stichting Beroepsgerichte opleidingen, in samenwerking met het Arbeidsbureau Nijmegen.

COA (1991), Inventarisatie van scholingsprojecten langs de Nederlandse grens, COA-Limburg, 1991, (intern verslag).

Euregio Maas-Rhein, Berufsbildungsexperiment (EVE-project). Endbericht über die Vorbereitungs phase 1985, ECWS.

Euregio Twente/Westmünsterland (1991), Beroepsopleidingen en Arbeidsmarkt. Rapport van de Stichting Grensoverschrijdende Beroepsopleiding. Gronau/Enschede. 

Hochschuldidaktisches Zentrum Aachen (1991), Partizipation, Innovation, Technikgestaltung. Arbeitnehmer Aus- und Weiterbildungsbüro für die Euregio Maas/Rhein, Ein Comett IIprojekt, Aachen.

Regio Rhein-Waal (1991), Schule, Ausbildung und Berufsperspektiven in der Grenzeregion-Am Beispiel der Regio Rhein-Waal. Symposium verslag 15/16 mei 1991, Emmerich.

\section{Andere samenwerkingsvormen in grensregio's}

Euregio Maas-Rijn, Onderzoeksinstellingen in de Euregio Maas-Rijn.

Euregio Inform, knipselkrant Euregio Twente-Westfalen.

Interregionale vakbondsraad, Problematieken van grensarbeiders. Rapport van de Commissie Grensarbeiders Euregio Maas-Rijn.

Verslag en resoluties van bijeenkomst Vakbondseuregio Maas-Rijn, 12 en 13 april 1991, Tongeren.

\section{OVERICE UTERATUUR}

ABP (1991), Aanvullende pensioenen en een verenigd Europa, Interne notitie CS/SBO/SV/ HVA, Algemeen Burgerlijk Pensioenfonds, Heerlen.

BEUC (1988), Transfer of Money within the EEC, Europees Bureau van Consumenten verenigingen-BEUC 76/88.

BSO/Artificial Intelligence (1991), Dienstencentra in het Buitenland. Verkennend onderzoek naar ervaringen met dienstencentra met geïntegreerde loketfuncties in Zweden, Italië, GrootBrittannië, lerland, Duitsland, België en Denemarken. Door dr. M.A.Nieuwenhuis, Utrecht.

Europese Commissie (1990), Het verrichten van betalingen op de interne markt. Discussiestuk. $\operatorname{COM}(90) 447$ def., Brussel.

Europese Commissie (1990), Levens- en arbeidsvoorwaarden van de burgers uit de Gemeenschap die in de grensgebieden wonen, met name de grensarbeiders. Mededeling van de Commissie.

Economie et Emploi: perspectives pour Liege. Resumé du colloque, Palais des Congrès de Liège, les 27 et 28 avril 1990.

FEM (1989), Halen de grensarbeiders 1992? in: Financieel-Economisch Magazine (18), 26 augustus 1989, pp.36-37.

Finanz Min. (1990), Bericht über die Behandlung verschiedener Gruppen von Grenzgängern und anderen Grenzlandbewohnern bei der Einkommensteuer/Lohnsteuer. Finanzamt, Bonn.

Goethals (1990), Grensarbeid in de Euregio Maas-Rijnland en Saar-Lor-Lux, onderzoeksverslag, Hoger instituut voor de Arbeid, Leuven. 
Grensregio Benelux Middengebied (1990), Operationeel Interreg-programma 1990-1993. Programma voor grensoverschrijdende samenwerking in het Benelux Middengebied.

Grensregio Rijn-Maas Noord (1986), Grensoverschrijdend Aktieprogramma voor de Grensregio Rijn-Maas Noord.

Grensregio Rijn-Maas Noord (1991), Grensoverschrijdend Uitvoeringsprogrammma. Samengesteld door Bureau BRO, Vught.

Grooten, M.H.P. (1991), De mogelijkheden en onmogelijkheden van EG-technologieprogramma's, in: Onderwijs in Europees perspectief. Reader studiemiddag op 3 mei 1991. Uitgave Stichting Technologie Centrum Limburg, Heerlen.

Hofstede, G.H. (1980), Culture's Consequences, International Differences in Work-Related Values, Sage Beverly-Hills.

IGA (1991), Projectvoorstel Intensieve Grensoverschrijdende Activiteiten, Y. Sterkendries en M.A.F. Soeren.

PRVL (1991), Provinciale Raad voor de volksgezondheid Limburg, Gezondheidszorg en de Limburgse grens, In: Volksgezondheidsverkenningen, juni 1991/l, Maastricht.

Schreuder, H. (1990), Strategische allianties: een inleidend overzicht, in: De strategische alliantie, alternatief voor fusie c.q. overname?, Tilburg.

Soeters, J. (1991), Het management van Euregionale netwerken, in: Binnenlands Bestuur (nog te verschijnen).

STPL (1991), Projectvoorstel Euregionale koppeling arbeidsbureaus. Stichting Telematica Platform Limburg. (Intern)

Tweede Kamer der Staten-Generaal (1990-1991), Verslag van de Staatssecretaris van Buitenlandse Zaken betreffende de Interne Markt Raad, dd. 18/19 juni 1991. Kenmerk: 21 501-01, nr. 27

Vlist, J.A. van der (1988), Werken langs de grens. Proefschrift Erasmus Universiteit Rotterdam. 


\section{BIJLAGE I: PERSONEN/INSTANTIES WAARMEE GESPREKKEN ZIJN GEVOERD}

\section{HOOFOLUNEN ONOERZOEK}

- mevr. Reggers, dhr. Konings, VDAB Tongeren

- M. Semer, FOREM Luik

- dhr. Meens, Arbeitsamt Aachen

- W. Friedrichs, J. Schipper, FNV Heerlen

- J. Maatjens, A. Janssen, J. Wouters, provincie Limburg/Euregio-bureau

- M. Depondt, M. Buskens, COA Limburg, Maastricht

- M. de Raeve, secretaris Grenspendelcommssie ACV Hasselt

- mevr. Zinn, dhr. Boltersdorf, Euregionaal Bureau Aken

\section{KWANTITATEF/KWALITATEFINZICHT IN PENOELSTROMEN}

- A. Crijns, KPMG Klynveld Management Consultants

- P. Hanraets, ETIL (telefonisch)

- H. Heinrichs, Landesamt Datenverarbeitung und Statistik Nord Rhein Westfalen (telefonisch)

- H. Cruysen, Eurostat, Luxemburg

\section{KNELPUNTEN (ALCEMEEN) EN INFRASTRUCTUUR UAN WFORMATEVOORZIENNGNOORLICHTNG}

- M. Soeren, Arbeidsbureau Westelijke Mijnstreek

- R. Le Bron de Vexela, personeelsconsulent AZM

- dhr. Reinaerts, hoofd personeels- en salarisadministratie AZM

- N. Bauer, Vereniging Europese Grenslandbewoners (VEG), pendelaar (Nederland - Duitsland)

- dhr. Velraad, Europees Informatiecentrum Kerkrade

- dhr. Meenk, hoofd personeelszaken VOLVO

- L. Bentlage, Deutsche Gewerkschafts Bund (DGB) Aachen

- dhr. Bielfeld, hoofd Personeelszaken Talbot Aken

- T. Looyschelder, Bureau voor Duitse Zaken, Nijmegen

- E. Walter, Bureau voor Belgische Zaken, Breda

- J. Beckers, KNP Hoofd Personeelszaken Servicegroep

- J. Wenderoth, Personalreferent Philips Glasfabrik Aken

- Groepsgesprek met Nederlandse werknemers Talbot (Aken)

- Groepsgesprek met Belgische CFO-leden Academisch Ziekenhuis Maastricht

- Groepsgesprek met Belgische en Nederlandse werknemers Philips Glasfabrik Aken

- mevr. S. Gorgels, LICE '92, Kamer van Koophandel, Heerlen. 


\section{Thema Arbeidsmarkt (3 oktober 1991):}

- dhr. P. Elferink (Stichting Werkgelegenheid en Arbeidsmarkt Limburg SWAL)

- dhr. F. Soeren (Arbeidsbureau Sittard)

- dhr. P. Janssen (Gemeente Maastricht)

- drs. J.J. Zwartjes (Economisch Technologisch Instituut Limburg, ETIL)

\section{Thema Onderwijs en Opleiding (10 oktober 1991):}

- drs. F. Boss (Stichting Technologie Centrum Limburg Heerlen)

- drs. H. Broekhuyse (lid Initiatiefgroep Euregiocongres)

- dhr. X. Christiaens (provinciale onderwijsinspectie, Provincie Belgisch Limburg)

- dr. H. Katterbach (Hand Werks Kammer Aachen)

- dhr. A.F. Reinierkens (Centrum Vakopleiding Volwassenen, Heerlen)

- dhr. J. v.d. Steyn (Limburgs Centrum voor Bedrijfsopleidingen, LCB)

- dhr. P. Willems (Limburgs Instituut voor Onderwijsonderzoek en -Oriëntatie, LIOO, Hasselt)

- prof. L. Soete (MERIT, Maastricht)

- Mr. Th. van der Voort (Centrum Vakopleiding Volwassenen, Maastricht)

- prof. H.C. de Wolf (Open Universiteit, Heerlen)

- dhr. F. Wolf (Provincie Nederlands Limburg)

\section{Thema Sociale Zekerheid en Pensioenen (21 oktober 1991):}

- dhr. J. van Aalst (Algemeen Burgerlijk Pensioenfonds, Heerlen)

- dhr. J. van Gils (Bureau voor Belgische Zaken, Breda)

- mevr. mr. E. van Hilten (GAK Amsterdam)

- dhr. J.W. Janssen (Bureau voor Duitse Zaken, Nijmegen)

- dhr. M. de Raeve (ACV - Dienst grensarbeiders, Hasselt)

\section{Thema Belastingen en Betalingen (22 oktober 1991):}

- dhr. N. Bauer (Vereniging Europese Grenslandbewoners, VEG)

- dhr. P. Bellefroid (Nationaal Christelijke Middenstandsvereniging, Hasselt)

- dhr. C. Hooy (NMB Postbank, Eindhoven)

- prof. W. Kaefer (Technische Hochschule Aachen, tevens adviseur VEG)

- dhr. J. Ketelsen (Europees Commissie, Divisie Arbeidsmarktpolitiek, Brussel)

- dhr. G. Koolen (NMB Postbank, Amsterdam)

- drs. J. Monsewije (Gemeente Kerkrade, Dienst Financiën)

- prof. R. Niessen (Rijksuniversiteit Limburg - Fiscaal Recht)

- dhr. M. de Raeve (ACV -Dienst grensarbeiders, Hasselt)

- dhr. F. Stevens (NMB Postbank, Maastricht)

- dhr. F. Suvrijn (Belastingdienst BPOB, Brunssum)

- dr. K. Verhoef (NMB Postbank, Amsterdam) 
